Department of Energy

National Nuclear Security Administration Nevada Site Office

P.O. Box 98518

Las Vegas, NV 89193-8518

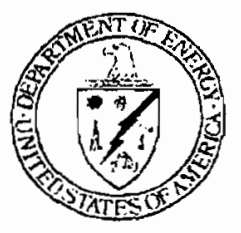

\title{
APH 222008
}

Tim Murphy, Chief

Bureau of Federal Facilities

Division of Environmental Protection

2030 East Flamingo Road, Suite 230

Las Vegas, NV 89119.0818

SUBMITTAL OF FINAL POST-CLOSURE INSPECTION LETTER REPORT FOR

CORRECTIVE ACTION UNITS ON THE NEVADA TEST SITE, Revision 0, April 2008,

This letter serves as the post-closure inspection letter report for the following Corrective Action Units (CAUs) for calendar year 2007:

CAU 5, Landfills

CAU 137, Waste Disposal Sites

CAU 140, Waste Dumps, Burn Pits, and Storage Area

CAU 143, Area 25 Contaminated Waste Dumps

CAU 165, Area 25 and 26 Dry Well and Washdown Areas

CAU 168, Area 25 and 26 Contaminated Materials and Waste Dumps

CAU 204, Storage Bunkers

CAU 214, Bunkers and Storage Areas

CAU 254, Area 25 R-MAD Decontamination Facility

CAU 261, Area 25 Test Cell A Leachfield System

CAU 262, Area 25 Septic Systems and UDP

CAU 271, Areas 25, 26, and 27 Septic Systems

CAU 309, Area 12 Muckpiles

CAU 322, Areas 1 \& 3 Release Sites and Injection Wells

CAU 335, Area 6 Injection Well and Drain Pit

CAU 339, Area 12 Fleet Operations Steam Cleaning Effluent

CAU 342, Area 23 Mercury Fire Training Pit

CAU 357, Mud Pits and Waste Dump

CAU 383, Arca 12 E-Tunnel Sites

CAU 528, Polychlorinated Biplenyls Contamination

CAU 529, Area 25 Contaminated Materials

CAU 542, Disposal Holes

CAU 551, Area 12 Muckpiles

CAU 552, Area 12 Muckpile and Ponds

CAU 554, Area 23 Release Site 


\section{Results for CAU 5}

CAU 5 sites were inspected on December 11, 2007 (Corrective Action Site [CAS] 20-15-01); December 17, 2007 (CAS 05-15-01); January 2, 2008 (CASs 06-08-01, 06-15-02, and 06-15-03); January 3, 2008 (CAS 12-15-01); and January 23, 2008 (CASs 05-16-01 and 23-15-03). CASs 20-15-01 and 23-15-03 are in excellent condition. Signs observed to have been down during last year's inspection had been re-hung and/or replaced starting in the spring and finishing in July 2007. Because of repeated sign loss due to heavy winds at CASs 06-15-02 and 06-15-03, existing $\mathrm{T}$-posts were replaced with heavy-duty posts, and signs were bolted to the posts. This action successfully mitigated damaged caused by the windy conditions, and no signs were down at either of those C.ASs during this year's inspection.

This year's inspection showed that signs were down at several of the CASs. One sign was down at CAS 05-15-01, two signs were down at CAS 05-16-01, and four signs were either down or needed to be otherwise reattached at CAS 12-15-01; however, the signs are still present and in good shape and will be re-hung. In addition to these sites, numerous signs were down, loose, or missing at CAS 06-08-01. These signs will be replaced or re-hung, as needed.

Several other minor maintenance items were identified. Sections of wire rope fence were down and will be rehung and/or replaced at CASs 06-08-01 and 12-15-01. Locks on the drivc-through gates at CAS 06-08-01 should be replaced with the standard post-closure site locks, for easier access. Although not required, one additional use restriction sign will be added for the second drive-through access gate at CAS 06-08-01. Maintenance and repairs will be scheduled by the end of March 2008.

Some evidence of ovcrland water flow is present on the cover near the middle of the C.ASs 06-15-02 and 06-15-03 site. This could be a result of recent heavy rains and does not prcsent a threat to the cover; however, this area should be monitored in the future to make sure that an erosion channel does not form.

\section{Results for CAU 137}

CAU 137 sites were inspected on January 16, 2008 (CASs 01-08-01 and 07-23-02), and January 23, 2008 (CASs 12-08-0 l and 12-23-07). The CAU was in excellent condition, and there are no issues to be addressed. No corrective actions are needed.

\section{Results for CAU 140}

CAU 140 sites were inspected on December 17, 2007 (CAS 05-23-01), and January 23, 2008 (CAS 23-17-01). CAS 05-23-01 was in excellent condition. One sign at CAS 23-17-01 is down and needs to be re-hung, and another needs to be tightened. This repair will be scheduled by the middle of March 2008. The CAU is otherwise in good condition. 


\section{Results for CAU 143}

CAU 143 was inspected on December 13,2007. One sign that was observed to be down at CAS 25-23-03 during the last inspection was re-hung in January 2007. This year's inspection showed CAS 25-23-03 to be in good condition with no corrective action needed. At CAS 25-23-09, six use restriction signs are down, loose, or missing, and three radioactive material signs need to be re-hung. These repairs were completed on March 11, 2008.

\section{Results for CAU 165}

CAU 165 was inspected on December 13, 2007. The CAU was in excellent condition, and there are no issues to be addressed. No corrective actions are needed.

\section{Results for CAU 168}

CAU 168 sites were inspected on December 13, 2007 (CASs 25-16-03 and 25-23-02), and December 17, 2007 (CAS 25-99-16). CASs 25-16-03 and 25-99-16 were in good condition, with no corrective actions needed. Five signs at CAS 25-23-02 are down and need to be re-hung, and another needs to be tightened. This repair will be scheduled by the middle of March 2008 . The CAU is otherwise in good condition.

\section{Results for CAU 204}

CAU 204 was inspected on Dccember 17, 2007 (CASs 05-18-02 and 05-33-01), and January 16, 2007 (CASs 01-34-01, 02-34-01, and 03-34-01). The CAU was in excellent condition, and there are no issues to be addressed. Some minor housekccping was identified at CAS 05-18-02 and consists of the removal of $\mathrm{T}$-posts that remain from closure activities. No corrective actions are needed.

\section{Results for CAU 214}

CAU 214 sites were inspected on December 13, 2007. The CAU was in good condition, and there are no issues to be addressed. No corrective actions are needed.

\section{Results for CAU 254}

CAU 254 was inspected on December 17, 2007. The CAU was in good condition, and there are no issues to be addressed. No corrective actions are needed.

\section{Results for CAU 261}

CAU 261 was inspected on December 13, 2007. One sign that was observed to be down during the last inspection was re-hung in January 2007. This year's inspection showed the CAU to be in good condition, and there are no issues to be addressed. No corrective actions are needed.

\section{Results for CAU 262}

CAU 262 was inspected on December 13,2007. One sign that was observed to be down during the last inspection at CAS 25-02-06 was re-hung and one sign at CAS 25-05-06 was reinforced in January 2007. This year's inspection showed that one sign at CAS 25-05-08 is missing and needs to be replaced. These repairs were completed on March 11, 2008. The CAU was otherwise in excellent condition. 


\section{Results for CAU 271}

CAU 271 was inspected on January 23, 2008. The CAU was in good condition, and there are no issues to be addressed. No corrective actions are needed.

\section{Results for CAU 309}

CAU 309 sites were inspected on February 12, 2008. Several radiological signs were observed to be in poor condition and need to be replaced. The CAU was otherwise in excellent condition. Repairs will be completed in 2008.

\section{Results for CAU 322}

CAU 322 was inspected on December 10,2007. The CAU was in good condition, and there are no issues to be addressed. No corrective actions are needed.

\section{Results for CAU 335}

CAU 335 was inspected on December 10, 2007. Signs and T-posts observed to have been down or damaged during last year's inspection were replaced and re-hung on September 19. 2007. Heavy-duty signposts to which the signs are bolted were obtained for these repairs. This change was made because of repeated sign damage caused by high winds at this site.

In this year's inspection, the majority of the use restriction signs and posts were in good condition; however, additional signs were damaged by high winds. Approximately ten small signs and one large sign were missing and need to be replaced. All damaged signs were on old $T$-posts. Sign maintenance and repairs were completed on February 27, 2008. During the repair work, additional signs were found to be danaged, missing, or down. These signs were replaced on March 11, 2008. Fence repair was also completed on February 20, 2008 as a best management practice.

\section{Results for CAU 339}

CAU 339 was inspected on December 10, 2007. This year's inspection showed the CAU to be in good condition, and there are no issues to be addressed. No corrective actions are needed.

\section{Results for CAU 342}

CAU 342 requires biannual inspections and was inspected on July 7, 2007, and January 23, 2008. The CAU was in good condition, and no issues were observed. No corrective actions are needed; however, the monitoring well no longer serves a purpose. Consequently, permanent abandonment of the well and a decrease in inspection frequency from biannual to every 5 years is recommended.

\section{Results for CAU 357}

CAU 357 was inspected on December 13, 2007 (CAS 25-15-01); January 16, 2008 (CAS 10-09-06); and January 23, 2008 (CAS 04-26-03). The CAU was in excellent condition, and there are no issues to be addressed. No corrective actions are needed. 


\section{Results for CAU 383}

CAU 383 was inspected on February 12,2008. The CAU was in excellent condition, and there are no issues to be addressed. No corrective actions are needed.

\section{Results for CAU 528}

CAU 528 was inspected on December 13,2007. Three signs were down and need to be reinstalled. This repair will be scheduled by the end of May 2008. The CAU was otherwise in good condition.

\section{Results for CAU 529}

CAU 529 was inspected on December 13, 2007. One sign from Parcel $\mathrm{H}$ was down and damaged and needs to be replaced. Repairs will be completed in 2008. The CAU was otherwise in good condition.

\section{Results for CAU 542}

CAU 542 sites were inspected on January 16, 2008. One sign at CAS 03-20-07 is down and needs to be re-hung, and one sign at CAS 03-20-10 is loose and needs to be tightened. Repairs will be completed in 2008. The CAU was otherwise in good condition.

\section{Results for CAU 551}

CAU 551 was inspected on February 12, 2008. One sign was down and needs to bc re-hung. Repairs will be completed in 2008 . The CAU was otherwise in good condition.

\section{Results for CAU 552}

CAU 552 was inspected on January 23, 2008. The CAU was in excellent condition, and there are no issues to be addressed. One strand of barbed wire was loose and will be tightened as a best management practice. No corrective actions are needed.

\section{Results for CAU 554}

CAU 554 was inspected on January 23, 2008. The CAU was in good condition, and there are no issues to be addressed. No corrective actions are needed.

Copies of the completed checklists for all site inspections, as well as other information required to be provided in this report, are attached.

Please direct comments and questions to Janis Romg, of staff, at (702) 295-0838.

ERP:4138.KC

Enclosure:

As stated /s/ John Jones

J6hn B. Jones

Acting Federal Project Director

Environmenlal Restoration Project 
cc w/encl. (uncontrolled):

Public Reading Facility Coordinator, SNJV, Las Vegas, NV (electronic copy)

Northern Nevada Public Reading Room, Carson City, NV (1 electronic copy)

Southern Nevada Public Reading Room, Las Vegas, NV (2 electronic copies)

Technical Library, NNSA/NSO, Las Vegas, NV (electronic copy)

NSTec Document Production (electronic copy to OSTI)

Ted Zaferatos, NDEP, Las Vegas, NV

T. A. Thiele, NSTec, Las Vegas, NV

R. F. Boelllecke, SNJV, Las Vegas, NV

G. Richardson, NSTec, Las Vegas, NV

A. J. Silvas, NSTcc, Las Vegas, NV

A. T. Urbon, NSTec, Las Vegas, NV

J. N. Romo, ERP, NNSA/NSO, Las Vegas, NV

cc w/o encl:

J. J. MacDougall, NDEP, Las Vegas, NV

Jeffrey Fraher, DTRA/CXTS, Kirtland AFB, NM

W. R. Griffin, SNJV/DTRA, M/S 645, Mercury, NV

E. F. Di Sanza, WMP, NNSANSO, Las Vegas, NV

K. J. Cabble, ERP, NNSA/NSO, Las Vegas, NV

EM Records, AMEM, Las Vegas, NV

FFACO Group, PSG, NNSA/NSO, Las Vegas, NV 


\section{Final Post-Closure} Inspection Letter Report for Corrective Action Units on the Nevada Test Site for Calendar Year 2007

Revision 0

April 2008 
CAU 5: LANDFILLS 


\section{POST-CLOSURE INSPECTION CHECKLIST}

\section{CAU 005: LANDFILLS - CAS 05-15-01, SANITARY LANDFILL}

\begin{tabular}{|l|l|}
\hline \hline Inspection Date and Time: $12 / 7 / 07 / 625$ & Reason for Inspection: ANALA/ \\
\hline Date of Last Post-Closure Inspection: $1 / 4 / 07$ & Reason for Last Post-Closure Inspection: A wN UA / \\
\hline
\end{tabular}

Responsible Entity: NSTec Environmental Restoration, Nevada Test Site, Mercury, Nevada

Responsible Facility Owner: Jeffrey L. Smith, Deputy Manager, Environmental Restoration

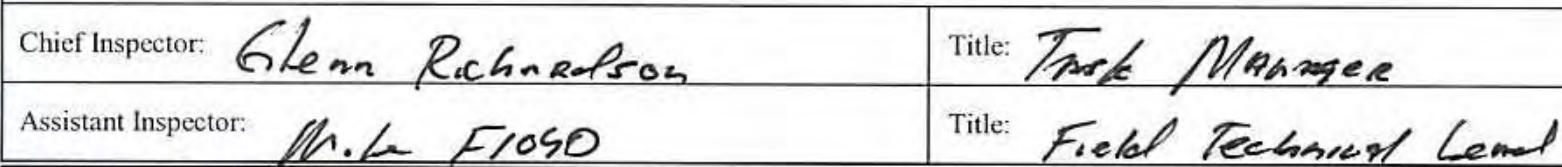

A. GENERAL INSTRUCTIONS

1. All checklist items must be completed and detailed comments made to document the results of the site inspection. The completed checklist is part of the field record of the inspection. Additional pages should be used as necessary to ensure that a complete record is made. Attach the additional pages and number all pages upon completion of the inspection.

2. Any checklist line item marked by an inspector in a SHADED BOX must be fully explained or an appropriate reference to previous reports provided. The purpose of this requirement is to provide a written explanation of inspector observations and the inspector's rationale for conclusions and recommendations. Explanations are to be placed on additional attachments and cross-referenced appropriately. Explanations, in addition to narrative, will take the form of sketches, measurements, and annotated site maps.

3. The site inspection is a walking inspection of the entire site including the perimeter and sufficient transects to be able to inspect the entire surface and all features specifically described in this checklist.

4. Field notes taken to assist in completion of this checklist will become part of the inspection record. No form is specified for field notes; however, they must be legible and in sufficient detail to enable review by succeeding inspectors and the responsible agency.

5. This unit will be inspected annually with formal reporting to the Nevada Division of Environmental Protection to be done annually. The annual letter report will include a summary with this inspection checklist attached.

B. PREPARATION (To be competed prior to site visit)

1. Has the Post-Closure Plan been reviewed?

2. Have the previous inspection reports been reviewed?

3. Were anomalies or trends detected on previous inspections?

4. Were maintenance or repairs performed since last inspection?

a. If yes, has site repair resulted in a change from as-built conditions?

b. If yes (to $4 \mathrm{a}$ ), are revised as-built plans available that reflect repair changes?

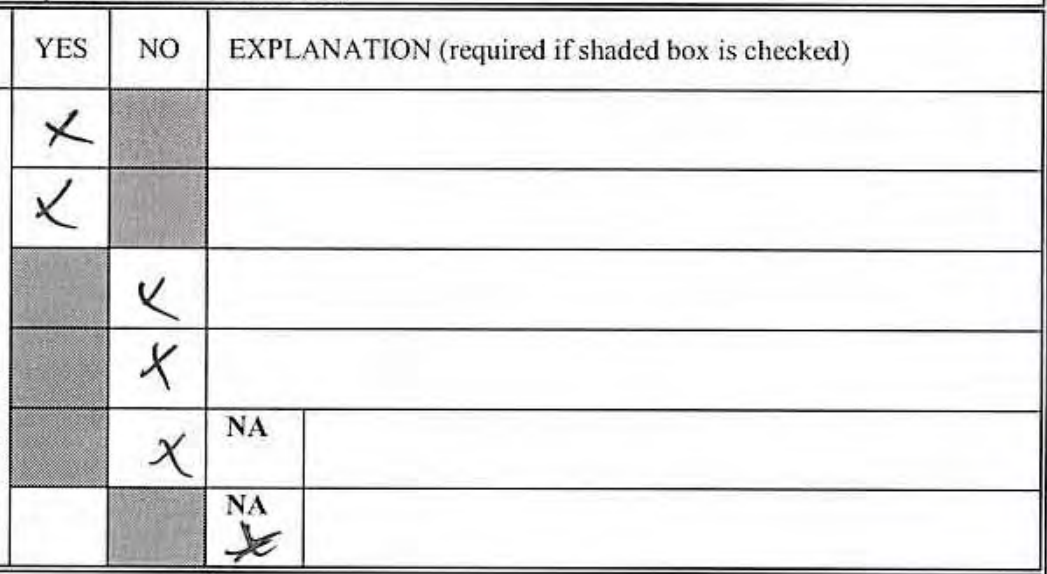

\section{SITE INSPECTION PREPARATION}

Assemble the following, as needed, to conduct inspections:

a. Radio, pager, etc.

b. Previous letter report, inspection checklists, repair records, and as-built plans

c. Other miscellaneous support equipment

\section{SITE INSPECTION}

1. Site markers:

a. Have any posts been damaged or their anchoring weakened?

b. Are any of the 11 use restriction signs damaged or missing?

c. Are all use restriction signs legible?

d. How many signs need to be replaced?

\begin{tabular}{|c|c|l||}
\hline YES & NO & EXPLANATION (required if shaded box is checked) \\
\hline & $x$ & \\
\hline & $x$ & /sign needs to Be Re-hers, Sign Pregest \\
\hline$x$ & & \\
\hline \multicolumn{1}{|c|}{} \\
\hline
\end{tabular}




\begin{tabular}{|c|c|c|c|}
\hline \multicolumn{4}{|c|}{ POST-CLOSURE INSPECTION CHECKLIST } \\
\hline \multicolumn{4}{|c|}{ CAU 005: LANDFILLS - CAS 05-15-01, SANITARY LANDFILL } \\
\hline \multirow[b]{2}{*}{ a. Is there evidence of settling? } & YES & NO & EXPLANATION (required if shaded box is checked) \\
\hline & & $x$ & \\
\hline b. Is there evidence of erosion (wind or water)? & & X & \\
\hline c. Is there evidence of human intrusion onto the site? & & $x$ & \\
\hline d. Is there evidence of large animal intrusion onto the site? & & $\chi$ & \\
\hline 3. Photograph Documentation (optional): & YES & NO & EXPLANATION \\
\hline a. Have photographs been taken of the site? & & 又 & \\
\hline \multicolumn{4}{|l|}{ If yes, how many photos werc taken? } \\
\hline If yes, has a photographic log been prepared? & & & Log number: \\
\hline E. FIELD CONCLUSIONS & YES & No & EXPLANATION (required if shaded box is checked) \\
\hline $\begin{array}{l}\text { 1. Is there an imminent hazard to the integrity of the site? } \\
\text { (Immediate report required) }\end{array}$ & & $\chi$ & \\
\hline \multicolumn{4}{|l|}{ Person/Agency to whom report was made: } \\
\hline \multicolumn{2}{|l|}{ 2. Are more frequent inspections required? } & $x$ & \\
\hline 3. Are existing maintenance/repair actions salisfactory? & X & & \\
\hline 4. Is other maintenance/repair necessary? & & $x$ & \\
\hline \multicolumn{4}{|c|}{ 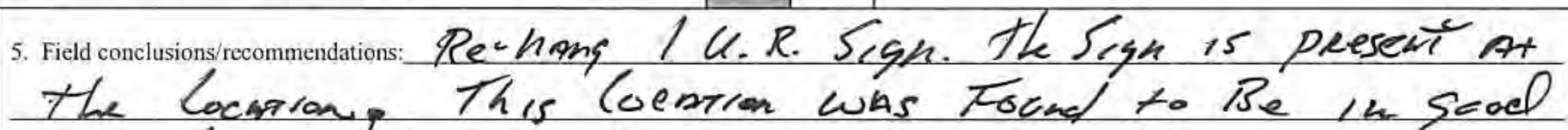 } \\
\hline \multicolumn{4}{|c|}{ Rond.tion Rxcept Duk the L K.R. } \\
\hline \multicolumn{4}{|l|}{ F, CERTIFICATION } \\
\hline \multicolumn{4}{|c|}{$\begin{array}{l}\text { I have conducted an inspection of CAS } 05-15-01 \text {, Sanitary Landfill, in accordance with the procedures of the Post-Closure Plan as recorded on this checklist, } \\
\text { attached sheets, field notes, photographs, and photograph logs. }\end{array}$} \\
\hline \multicolumn{2}{|c|}{ Chief Inspector's Signature: /s/ Glenn Richardson } & Date: & $12 / 17,07$ \\
\hline Printed Name: G/ene Relaquesch & & & TASK Mlan \\
\hline
\end{tabular}




\section{POST-CLOSURE INSPECTION CHECKLIST}

\section{CAU 005: LANDFILLS - CAS 05-16-01, LANDFILL}

\begin{tabular}{||l|l|}
\hline \hline Inspection Date and Time: $1 / 23 / 08 /: 54 \mathrm{PM}$ & Reason for Inspection: Annual \\
\hline Date of Last Post-Closure Inspection: $1 / 4 / 07$ & Reason for Last Post-Closure Inspection: Annua / \\
\hline
\end{tabular}

Responsible Entity: NSTec Environmental Restoration, Nevada Test Site, Mercury, Nevada

Responsible Facility Owner: Jeffrey L. Smith, Deputy Manager, Environmental Restoration

\begin{tabular}{|l|l|}
\hline chief Inspector: Glenn Richardson & Title: Task Manager \\
\hline Assistant Inspector: Robert Green & Title: Field Techuical Lead \\
\hline \hline
\end{tabular}

A. GENERAL INSTRUCTIONS

1. All checklist items must be completed and detailed comments made to document the results of the site inspection. The completed checklist is part of the field record of the inspection. Additional pages should be used as necessary to ensure that a complete record is made. Attach the additional pages and number all pages upon completion of the inspection.

2. Any checklist line item marked by an inspector in a SHADED BOX must be fully explained or an appropriate reference to previous reports provided. The purpose of this requirement is to provide a written explanation of inspector observations and the inspector's rationale for conclusions and recommendations. Explanations are to be placed on additional attachments and cross-referenced appropriately. Explanations, in addition to narrative, will take the form of sketches, measurements, and annotated site maps.

3. The site inspection is a walking inspection of the entire site including the perimeter and sufficient transects to be able to inspect the entire surface and all features specifically described in this checklist.

4. Field notes taken to assist in completion of this checklist will become part of the inspection record. No form is specified for field notes; however, they must be legible and in sufficient detail to enable review by succeeding inspectors and the responsible agency.

5. This unit will be inspected annually with formal reporting to the Nevada Division of Environmental Protection to be done annually. The annual letter report will include a summary with this inspection checklist attached.

\begin{tabular}{l}
\hline \hline B. PREPARATION (To be competed prior to site visit) \\
$\begin{array}{l}\text { 1. Has the Post-Closure Plan been reviewed? } \\
\text { 3. Were anomalies or trends detected on previous inspections? }\end{array}$ \\
$\begin{array}{l}\text { 4. Was maintenance or repairs performed since last inspection? } \\
\text { a. If so, has site repair resulted in a change from as-built } \\
\text { conditions? }\end{array}$
\end{tabular}

\section{SITE INSPECTION PREPARATION}

Assemble the following, as needed, to conduct inspections:

a. Radio, pager, etc.

b. Previous letter report, inspection checklists, repair records, and as-built plans

c. Other miscellaneous support equipment

\section{SITE INSPECTION}

1. Site markers East of Berm:

a. Have any posts been damaged or their anchoring weakened?

b. Are any of the use restriction signs damaged or missing?

c. Are all use restriction signs legible?

d. How many signs need to be replaced?

\begin{tabular}{|c|l|l||}
\hline YES & NO & EXPLANATION (required if shaded box is checked) \\
\hline & & \\
\hline & & \\
\hline & & $\begin{array}{l}\text { No signs need to be replaced, but } 2 \text { signs } \\
\text { were down and need to be re hung. }\end{array}$ \\
\hline
\end{tabular}




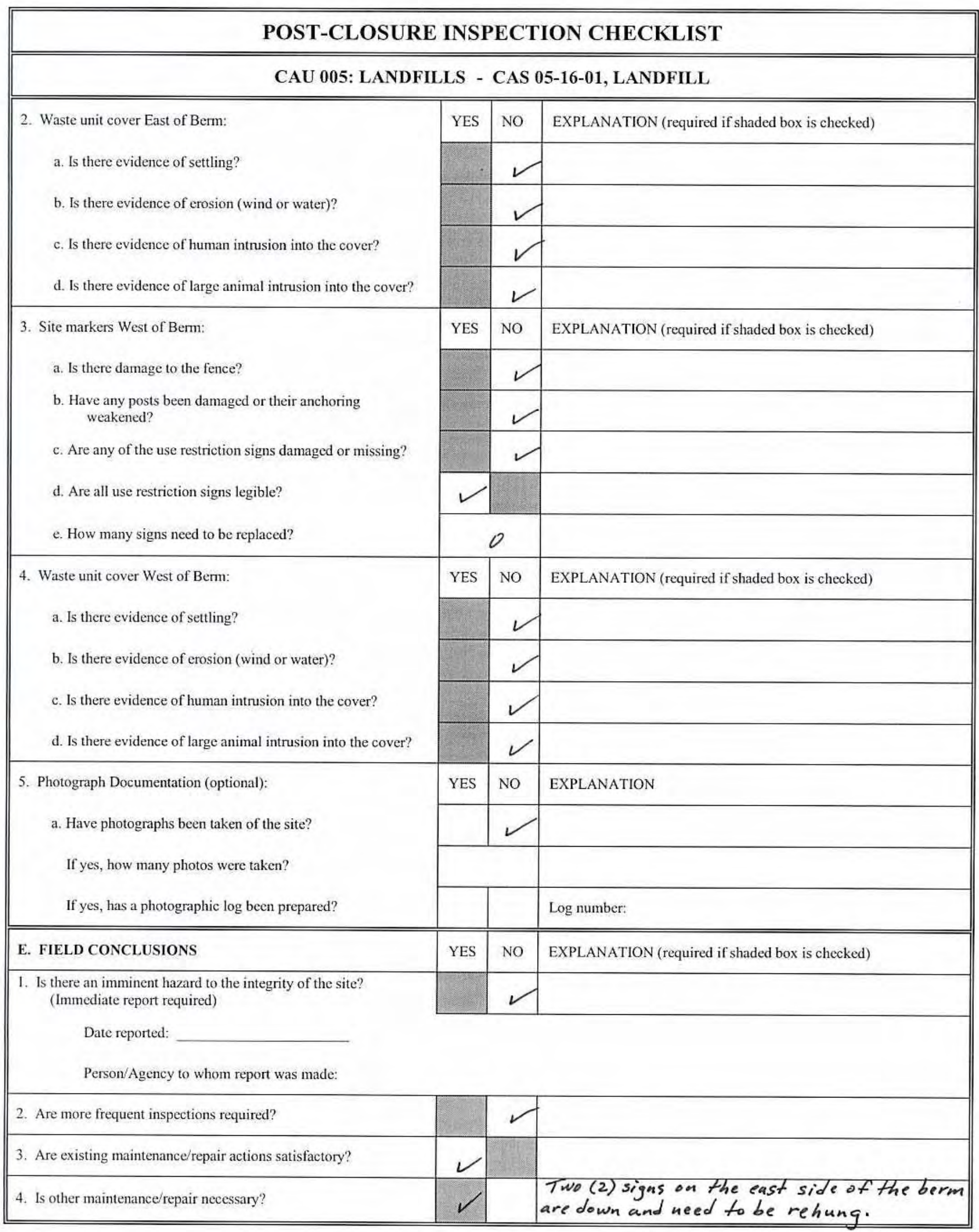




\section{POST-CLOSURE INSPECTION CHECKLIST}

\section{CAU 005: LANDFILLS - CAS 05-16-01, LANDFILL}

5. Field conclusions/recommendations: The use restriction signs and T-posts are in good condition on the east side of the berm. Two (2) signs were Lown and will need to be rehung. On the west side of the berm, the wire rope fencing and $U R$ signage are in excellent condition. The only follow-up action is reguired on the east side of the berm.

\section{F. CERTIFICATION}

I have conducted an inspection of CAS 05-16-01, Landfill, in accordance with the procedures of the Post-Closure Plan as recorded on this checklist, attached sheets, field notes, photographs, and photograph logs.

Chief Inspector's Signature: /s/ Glenn Richardson

Date: $\frac{1 / 23 / 08}{\text { Title: Task Manager }}$




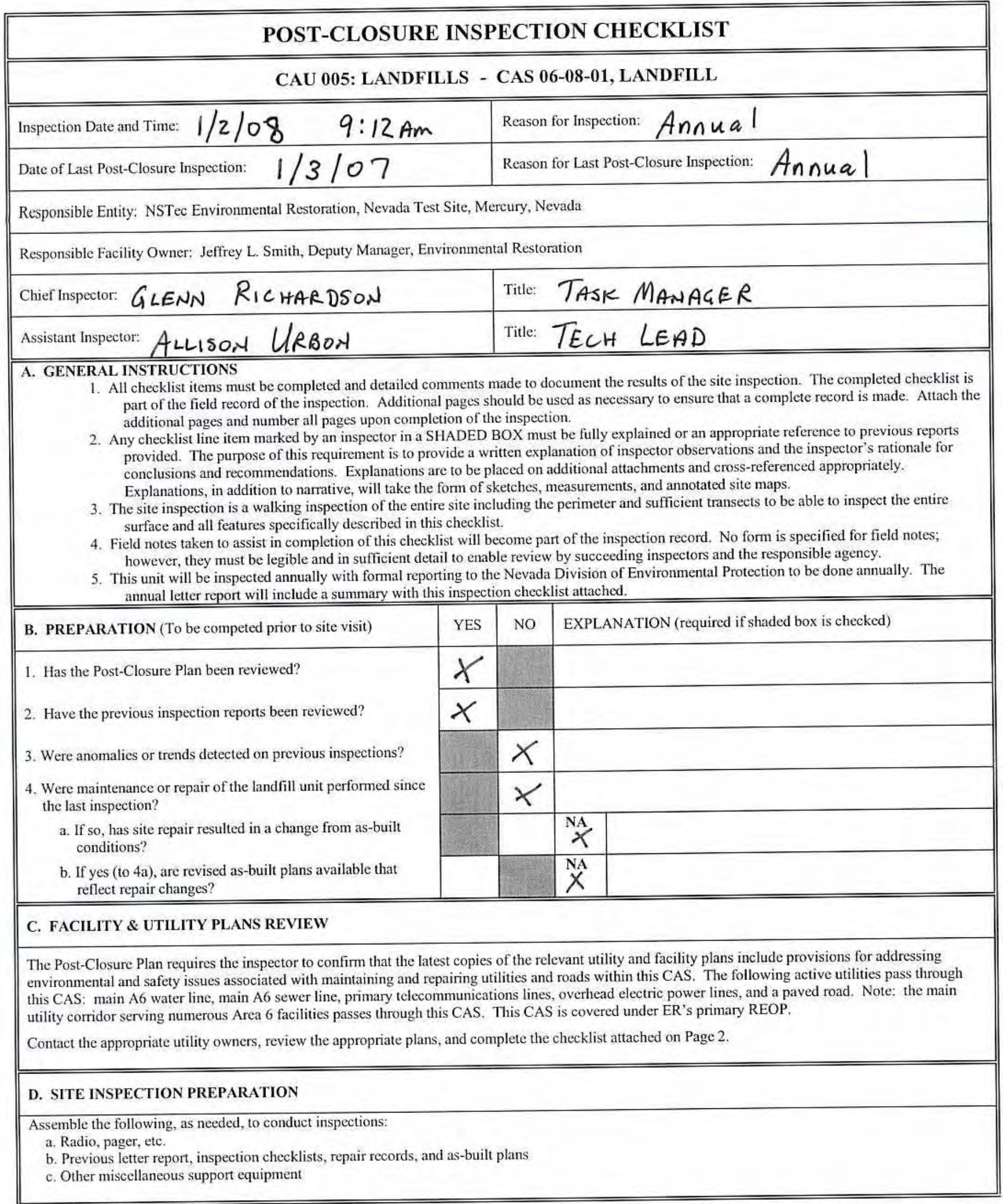




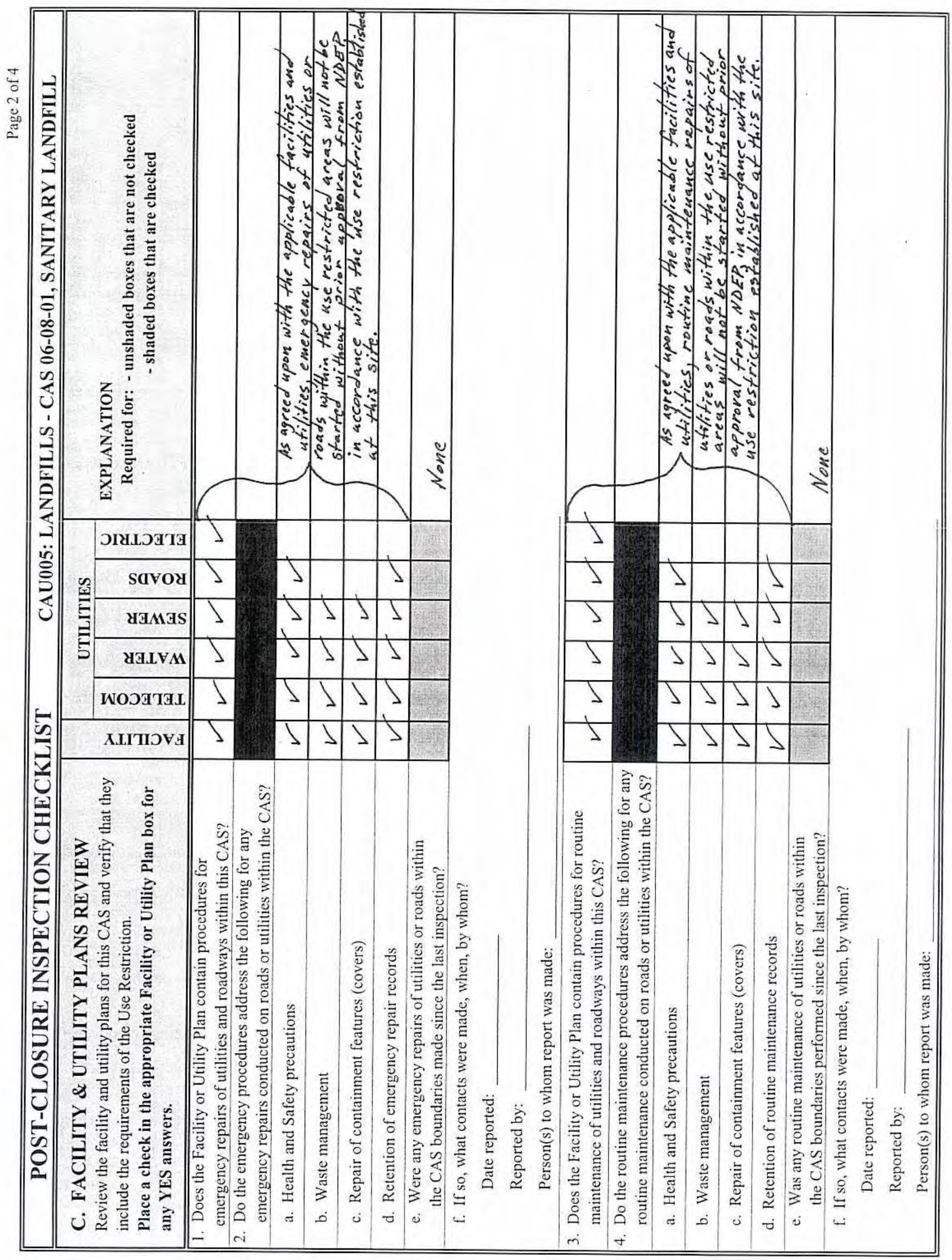




\section{POST-CLOSURE INSPECTION CHECKLIST}

\section{CAU 005: LANDFILLS - CAS 06-08-01, LANDFILL}

\section{E. SITE INSPECTION}

1. Site markers around fenced area:

a. Is there damage to the gates?

b. Are the gate locks in place and functional?

c. Is there damage to the fence?

d. Have any posts been damaged or their anchoring weakened?

e. Are any of the use restriction signs damaged or missing?

f. Are all use restriction signs legible?

g. How many signs need to be replaced?

2. Waste unit cover in fenced area:

a. Is there evidence of settling?

b. Is there evidence of erosion (wind or water)?

c. Is there evidence of human intrusion into the cover?

d. Is there evidence of large animal intrusion into the cover?

3. Site markers from south boundary of use restricted area to fence:
a. Are any bollards (that protect the use restriction signage) damaged or missing?
b. Have any posts been damaged or their anchoring weakened?
c. Are any of the use restriction signs damaged or missing?
d. Are all use restriction signs legible?
e. How many signs need to be replaced?

4. Waste unit cover from south boundary of use restricted area to fence:
a. Is there evidence of settling?
b. Is there evidence of erosion (wind or water)?
c. Is there evidence of human intrusion into the cover?
d. Is there evidence of large animal intrusion into the cover?

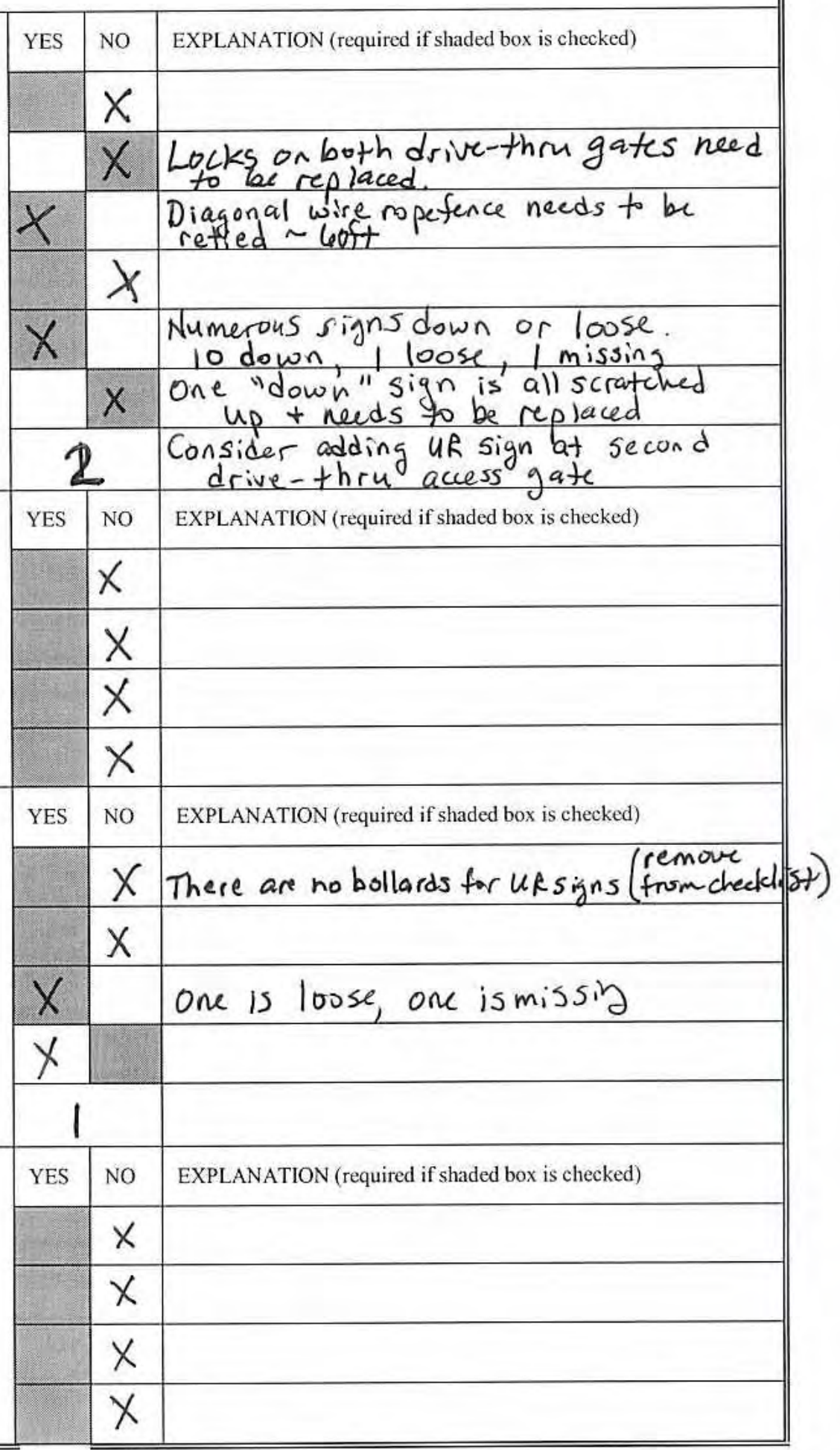




\section{POST-CLOSURE INSPECTION CHECKLIST}

\section{CAU 005: LANDFILLS - CAS 06-08-01, LANDFILL}

5. Photograph Documentation (optional):

a. Have photographs been taken of the site?

If yes, how many photos were taken?

If yes, has a photographic log been prepared?

\section{E. FIELD CONCLUSIONS}

1. Is there an imminent hazard to the integrity of the site? (Immediate report required)

\begin{tabular}{|c|c|l|}
\hline YES & NO & EXPLANATION \\
\hline & $X$ & \\
\hline \multicolumn{1}{|c|}{} & E & \\
\hline & $X$ & Log number: \\
\hline YES & NO & EXPLANATION (required if shaded box is checked) \\
& $X$ & \\
\hline
\end{tabular}

Date reported:

Person/Agency to whom report was made:

2. Are more frequent inspections required?

3. Are existing maintenance/repair actions satisfactory?

4. Is other maintenance/repair necessary?

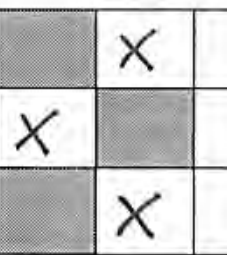

5. Field conclusions/recommendations: The site fencing is in good condition. There is no evidence of setfling or erosion on the waste unit cover. There are approximately ten (10) use restriction signs down, a comple of signs loose that need to be tightened, and a couple of signs missing that will need to be replaced.

\section{F. CERTIFICATION}

I have conducted an inspection of CAS 06-08-01, Landfill, in accordance with the procedures of the Post-Closure Plan as recorded on this checklist, attached sheets, field notes, photographs, and photograph logs.

Chief Inspector's Signature: /s/ Glenn Richardson

Printed Name:
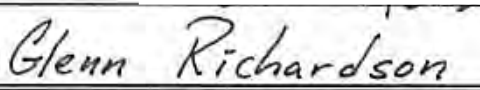

Date: $1 / 2 / 08$




\section{POST-CLOSURE INSPECTION CHECKLIST}

\section{CAU 005: LANDFILLS - CAS 06-15-02, SANITARY LANDFILL} CAS 06-15-03, SANITARY LANDFILL, BURN PIT

\begin{tabular}{|l|l|}
\hline \hline Inspection Date and Time: $1 / 2 / 08$ & Reason for Inspection: Annua $)$ \\
\hline Date of Last Post-Closure Inspection: $1 / \$ / 07$ & Reason for Last Post-Closure Inspection: Annual \\
\hline
\end{tabular}

Responsible Entity: NSTec Environmental Restoration, Nevada Test Site, Mercury, Nevada

Responsible Facility Owner: Jeffrey L. Smith, Deputy Manager, Environmental Restoration

\begin{tabular}{|l|l}
\hline Chief Inspector: GLENN RICHARDSON & Title: TASK MANAGER \\
\hline Assistant Inspector: ALLISON URBON & Title: TECH LEAD
\end{tabular}

A. GENERAL INSTRUCTIONS

1. All checklist items must be completed and detailed comments made to document the results of the site inspection. The completed checklist is part of the field record of the inspection. Additional pages should be used as necessary to ensure that a complete record is made. Attach the additional pages and number all pages upon completion of the inspection.

2. Any checklist line item marked by an inspector in a SHADED BOX must be fully explained or an appropriate reference to previous reports provided. The purpose of this requirement is to provide a written explanation of inspector observations and the inspector's rationale for conclusions and recommendations. Explanations are to be placed on additional attachments and cross-referenced appropriately. Explanations, in addition to narrative, will take the form of sketches, measurements, and annotated site maps.

3. The site inspection is a walking inspection of the entire site including the perimeter and sufficient transects to be able to inspect the entire surface and all features specifically described in this checklist.

4. Field notes taken to assist in completion of this checklist will become part of the inspection record. No form is specified for field notes; however, they must be legible and in sufficient detail to enable review by succeeding inspectors and the responsible agency.

5. This unit will be inspected annually with formal reporting to the Nevada Division of Environmental Protection to be done annually. The annual letter report will include a summary with this inspection checklist attached.

B. PREPARATION (To be competed prior to site visit)

1. Has the Post-Closure Plan been reviewed?

2. Have the previous inspection reports been reviewed?

3. Were anomalies or trends detected on previous inspections?

4. Were maintenance or repairs performed since last inspection?

a. If yes, has site repair resulted in a change from as-built conditions?

b. If yes (to $4 a$ ), are revised as-built plans available that reflect repair changes?

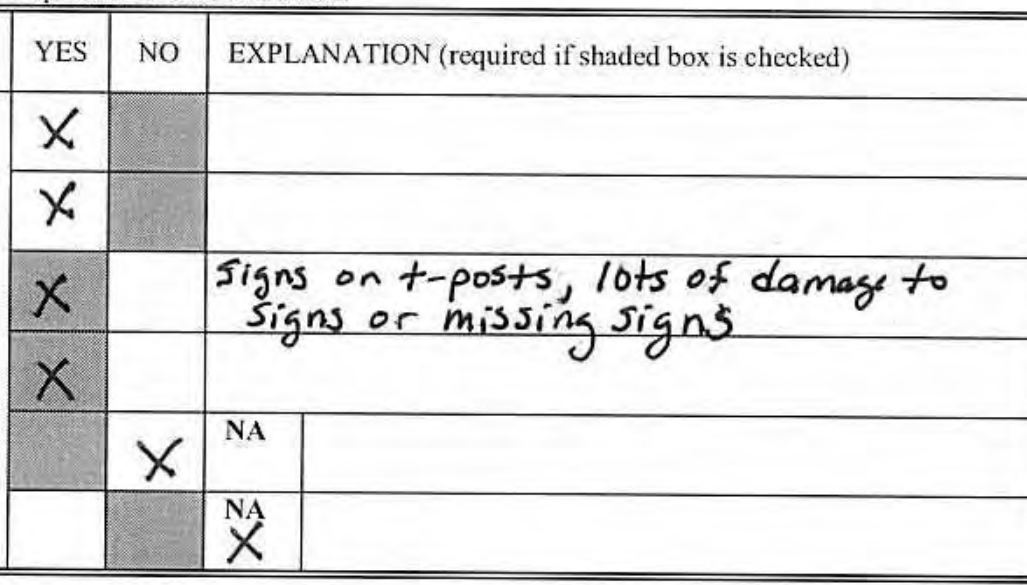

\section{SITE INSPECTION PREPARATION}

Assemble the following, as needed, to conduct inspections:

a. Radio, pager, etc.

b. Previous letter report, inspection checklists, repair records, and as-built plans

c. Other miscellaneous support equipment

\section{SITE INSPECTION}

1. Site markers:

a. Have any posts been damaged or their anchoring weakened?

b. Are any of the use restriction signs damaged or missing?

c. Are all use restriction signs legible?

d. How many signs need to be replaced?

\begin{tabular}{|l|l|l|}
\hline YES & NO & EXPLANATION (required if shaded box is checked) \\
\hline & $X$ & \\
\hline & $X$ & \\
\hline & & \\
\hline
\end{tabular}




\begin{tabular}{|c|c|c|c|}
\hline \multicolumn{4}{|c|}{ POST-CLOSURE INSPECTION CHECKLIST } \\
\hline \multicolumn{4}{|c|}{$\begin{aligned} \text { CAU 005: LANDFILLS - CAS 06-15-02, SANITARY LANDFILL } \\
\text { CAS 06-15-03, SANITARY LANDFILL, BURN PIT } \\
\end{aligned}$} \\
\hline \multirow{2}{*}{$\begin{array}{l}\text { 2. Waste unit covers: } \\
\text { a. Is there evidence of settling? }\end{array}$} & YES & NO & EXPLANATION (required if shaded box is checked) \\
\hline & & & \\
\hline b. Is there evidence of erosion (wind or water)? & $x$ & & $\begin{array}{l}\text { Minor-centar of site, keepan eye on } \\
\text { it in future to make sure that }\end{array}$ \\
\hline c. Is there evidence of human intrusion into the covers? & & $\times$ & water does not cut deeper. \\
\hline d. Is there evidence of large animal intrusion into the co & & X & \\
\hline 3. Photograph Documentation (optional): & YES & NO & EXPLANATION \\
\hline a. Have photographs been taken of the site? & & X & \\
\hline If yes, how many photos were taken? & e & & \\
\hline If yes, has a photographic log been prepared? & & X & Log number: \\
\hline E. FIELD CONCLUSIONS & YES & NO & EXPLANATION (required if shaded box is checked) \\
\hline $\begin{array}{l}\text { 1. Is there an imminent hazard to the integrity of the site? } \\
\text { (Immediate report required) }\end{array}$ & & $x$ & \\
\hline $\begin{array}{l}\text { Date reported: } \\
\text { Person/Agency to whom report was made: }\end{array}$ & & & \\
\hline 2. Are more frequent inspections required? & & $x$ & \\
\hline 3. Are existing maintenance/repair actions satisfactory? & $x$ & & \\
\hline 4. Is other maintenance/repair necessary? & & $x$ & \\
\hline $\begin{array}{l}\text { 5. Field conclusions/recommendations: Signs in } \\
\text { bolted to posts provide st } \\
\text { landfill area, some evidence } \\
\text { develop. This area should b }\end{array}$ & $\begin{array}{l}\text { ent } \\
\text { sec } \\
\text { verto } \\
\text { to }\end{array}$ & co & $\begin{array}{l}\text { adition. New posts with signs } \\
\text { anchor. In center of entive } \\
\text { water flow isstarting to } \\
\text { venify that it does not cut into cove }\end{array}$ \\
\hline F. CERTIFICATION & & & \\
\hline $\begin{array}{l}\text { Thave conducted an inspection of CAS 06-15-02, Sanitary La } \\
\text { the Post-Closure Plan as recorded on this checklist, attached s }\end{array}$ & $\begin{array}{l}\text { dCAS } \\
\text { Id note: }\end{array}$ & pho & $\begin{array}{l}\text { Sanitary Landfill, Burn Pits, in accordance with the procedures of } \\
\text { aphs, and photograph logs. }\end{array}$ \\
\hline Chief Inspector's Signature: /s/ Glenn Richardson & & Date: & $1 / 2 /$ \\
\hline Printed Name: Glenn Richardson & & Title: & Task Manager \\
\hline
\end{tabular}




\section{POST-CLOSURE INSPECTION CHECKLIST}

\section{CAU 005: LANDFILLS - CAS 12-15-01, SANITARY LANDFILL}

\begin{tabular}{|c|c|}
\hline Inspection Date and Time: & Reason for Inspection: \\
\hline Date of Last Post-Closure Inspection: & Reason for Last Post-Closure Inspection: \\
\hline
\end{tabular}

Responsible Entity: NSTec Environmental Restoration, Nevada Test Site, Mercury, Nevada

Responsible Facility Owner: Jeffrey L. Smith, Deputy Manager, Environmental Restoration

\begin{tabular}{|l|l}
\hline Chief Inspector: Glenn Tichardson & Title: Task Manager \\
\hline Assistant Inspector: Robert Green & Title: FieldTechnical Lrad
\end{tabular}

A. GENERAL INSTRUCTIONS

1. All checklist items must be completed and detailed comments made to document the results of the site inspection. The completed checklist is part of the field record of the inspection. Additional pages should be used as necessary to ensure that a complete record is made. Attach the additional pages and number all pages upon completion of the inspection.

2. Any checklist line item marked by an inspector in a SHADED BOX must be fully explained or an appropriate reference to previous reports provided. The purpose of this requirement is to provide a written explanation of inspector observations and the inspector's rationale for conclusions and recommendations. Explanations are to be placed on additional attachments and cross-referenced appropriately. Explanations, in addition to narrative, will take the form of sketches, measurements, and annotated site maps.

3. The site inspection is a walking inspection of the entire site including the perimeter and sufficient transects to be able to inspect the entire surface and all features specifically described in this checklist.

4. Field notes taken to assist in completion of this checklist will become part of the inspection record. No form is specified for field notes; however, they must be legible and in sufficient detail to enable review by succeeding inspectors and the responsible agency.

5. This unit will be inspected annually with formal reporting to the Nevada Division of Environmental Protection to be done annually. The annual letter report will include a summary with this inspection checklist attached.

\begin{tabular}{||l|l|l|}
\hline B. PREPARATION (To be competed prior to site visit) & YES & NOXPLANATION (required if shaded box is checked) \\
\hline 1. Has the Post-Closure Plan been reviewed? & Have the previous inspection reports been reviewed? \\
3. Were anomalies or trends detected on previous inspections? & Was maintenance or repair of the landfill unit performed since \\
the last inspection? & a. If yes, has site repair resulted in a change from as-built \\
conditions? & b. If yes (to 4a), are revised as-built plans available that \\
reflect repair changes? & &
\end{tabular}

\section{FACILITY \& UTILITY PLANS REVIEW}

The Post-Closure Plan requires the inspector to confirm that the latest copies of the relevant utility and facility plans include provisions for addressing environmental and safety issues associated with maintaining and repairing utilities and roads within this CAS. The following active utilities pass through this CAS: the main sewer line serving the Area 12 Camp the length of the CAS, overhead electrical power lines, one underground power line from the pole line to the sewer flow-meter shed, a road the length of the CAS, and the power line road.

Contact the appropriate facility and utility owners, review the appropriate plans, and complete the checklist attached on Page 2.

\section{SITE INSPECTION PREPARATION}

Assemble the following, as needed, to conduct inspections:

a. Radio, pager, etc.

b. Previous letter report, inspection checklists, repair records, and as-built plans

c. Other miscellaneous support equipment 


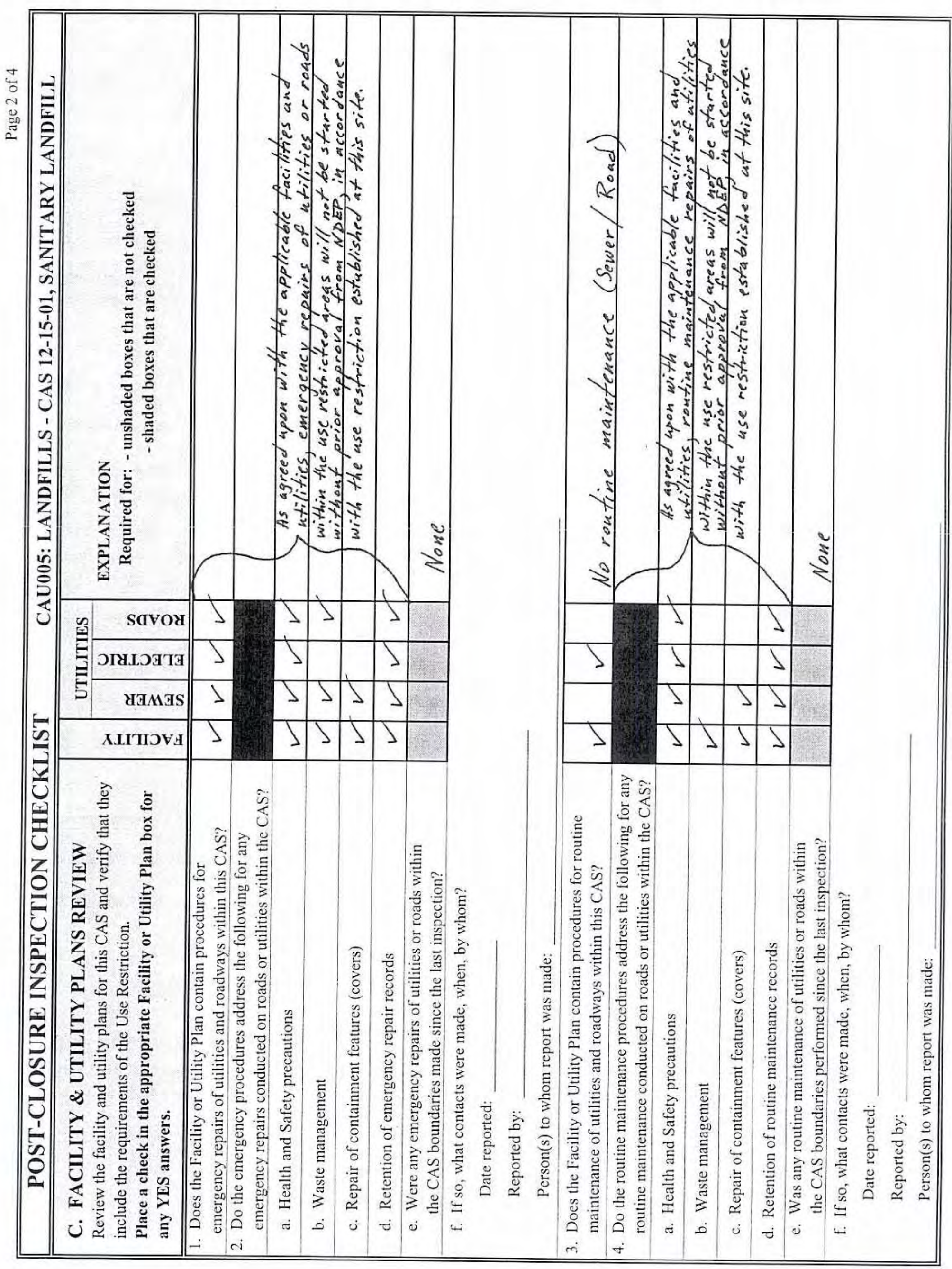




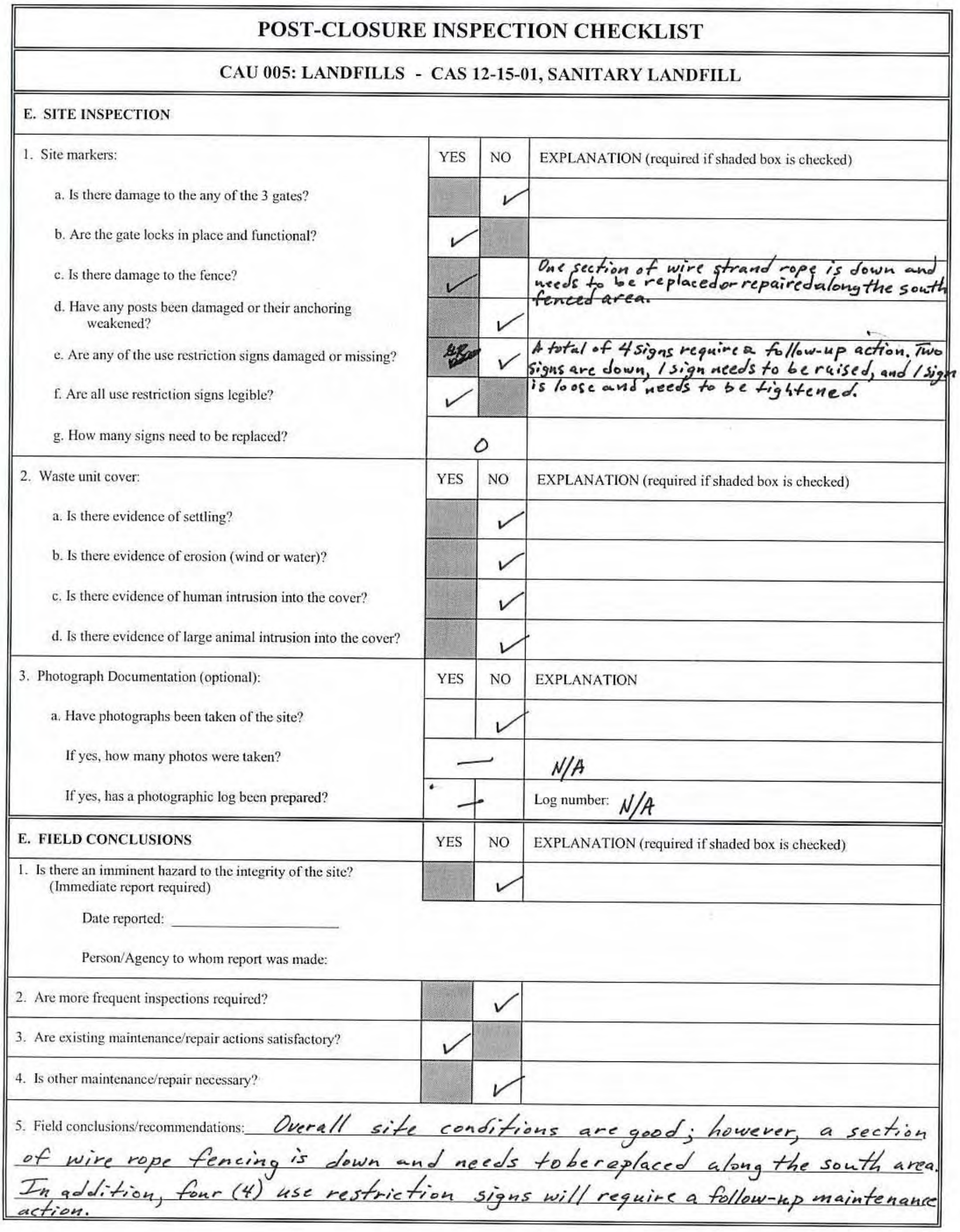




\begin{tabular}{||l||}
\hline \multicolumn{2}{|c||}{ POST-CLOSURE INSPECTION CHECKLIST } \\
\hline \hline \multicolumn{2}{|c||}{ CAU 005: LANDFILLS - CAS 12-15-01, SANITARY LANDFILL } \\
\hline \hline $\begin{array}{l}\text { F. CERTIFICATION } \\
\text { attached sheets, field notes, photographs, and photograph logs. }\end{array}$ \\
\hline Chief Inspector's Signature: /s/ Glenn Richardson \\
\hline Printed Name:
\end{tabular}




\section{POST-CLOSURE INSPECTION CHECKLIST}

\section{CAU 005: LANDFILLS - CAS 20-15-01, LANDFILL}

\begin{tabular}{|c|c|}
\hline Inspection Date and Time: $12 / 11 / 07$ Approx. 2:00 PM & Reason for Inspection: Annual \\
\hline Date of Last Post-Closure Inspection: & Reason for Last Post-Closure Inspection: Annual \\
\hline
\end{tabular}

Responsible Entity: NSTec Environmental Restoration, Nevada Test Site, Mercury, Nevada

Responsible Facility Owner: Jeffrey L. Smith, Deputy Manager, Environmental Restoration

\begin{tabular}{l|l}
\hline Chief Inspector: Brian Konrad & Title: ER Field Operations Manager \\
\hline Assistant Inspector: & Title:
\end{tabular}

A. GENERAL INSTRUCTIONS

1. All checklist items must be completed and detailed comments made to document the results of the site inspection. The completed checklist is part of the field record of the inspection. Additional pages should be used as necessary to ensure that a complete record is made. Attach the additional pages and number all pages upon completion of the inspection.

2. Any checklist line item marked by an inspector in a SHADED BOX must be fully explained or an appropriate reference to previous reports provided. The purpose of this requirement is to provide a written explanation of inspector observations and the inspector's rationale for conclusions and recommendations. Explanations are to be placed on additional attachments and cross-referenced appropriately. Explanations, in addition to narrative, will take the form of sketches, measurements, and annotated site maps.

3. The site inspection is a walking inspection of the entire site including the perimeter and sufficient transects to be able to inspect the entire surface and all features specifically described in this checklist.

4. Field notes taken to assist in completion of this checklist will become part of the inspection record. No form is specified for field notes; however, they must be legible and in sufficient detail to enable review by succeeding inspectors and the responsible agency.

5. This unit will be inspected annually with formal reporting to the Nevada Division of Environmental Protection to be done annually. The annual letter report will include a summary with this inspection checklist attached.

B. PREPARATION (To be competed prior to site visit)

1. Has the Post-Closure Plan been reviewed?

2. Have the previous inspection reports been reviewed?

3. Were anomalies or trends detected on previous inspections?

4. Were maintenance or repairs performed since last inspection?

a. If yes, has site repair resulted in a change from as-built conditions?

b. If yes (to $4 \mathrm{a}$ ), are revised as-built plans available that reflect repair changes?

\begin{tabular}{|l|l|l||}
\hline YES & NO & \multicolumn{1}{|||}{ EXPLANATION (required if shaded box is checked) } \\
\hline & & \\
\hline & & \\
\hline & & \\
\hline & & NA \\
\hline & & NA \\
\hline
\end{tabular}

\section{SITE INSPECTION PREPARATION}

Assemble the following, as needed, to conduct inspections:

a. Radio, pager, etc.

b. Previous letter report, inspection checklists, repair records, and as-built plans

c. Other miscellaneous support equipment

\section{SITE INSPECTION}

1. Site markers:

a. Have any posts been damaged or their anchoring weakened?

b. Are any of the use restriction signs damaged or missing?

c. Are all use restriction signs legible?

d. How many signs need to be replaced?

\begin{tabular}{|l|l|l||}
\hline YES & NO & EXPLANATION (required if shaded box is checked) \\
\hline & & \\
\hline & & \\
\hline & & \\
\hline & & \\
\hline
\end{tabular}




\begin{tabular}{|c|c|c|c|}
\hline \multicolumn{4}{|c|}{ POST-CLOSURE INSPECTION CHECKLIST } \\
\hline \multicolumn{4}{|c|}{ CAU 005: LANDFILLS - CAS 20-15-01, LANDFILL } \\
\hline \multirow{2}{*}{$\begin{array}{l}\text { 2. Waste unit covers: } \\
\text { a. Is there evidence of settling? }\end{array}$} & YES & NO & EXPLANATION (required if shaded box is checked) \\
\hline & & & \\
\hline \multicolumn{4}{|l|}{ b. Is there evidence of erosion (wind or water)? } \\
\hline \multicolumn{4}{|l|}{ c. Is there evidence of human intrusion into the cover? } \\
\hline \multicolumn{4}{|c|}{ d. Is there evidence of large animal intrusion into the cover? } \\
\hline \multirow{2}{*}{$\begin{array}{l}\text { 3. Photograph Documentation (optional): } \\
\text { a. Have photographs been taken of the site? }\end{array}$} & YES & NO & EXPLANATION \\
\hline & & & \\
\hline \multicolumn{4}{|l|}{ If yes, how many photos were taken? } \\
\hline If yes, has a photographic log been prepared? & & & Log number: \\
\hline E. FIELD CONCLUSIONS & YES & No & EXPLANATION (required if shaded box is checked) \\
\hline \multicolumn{4}{|l|}{$\begin{array}{l}\text { 1. Is there an imminent hazard to the integrity of the site? } \\
\text { (Immediate report required) }\end{array}$} \\
\hline \multicolumn{4}{|l|}{ Person/Agency to whom report was made: } \\
\hline \multicolumn{4}{|l|}{ 2. Are more frequent inspections required? } \\
\hline \multicolumn{4}{|l|}{ 3. Are existing maintenance/repair actions satisfactory? } \\
\hline \multicolumn{4}{|l|}{ 4. Is other maintenance/repair necessary? } \\
\hline \multicolumn{4}{|c|}{$\begin{array}{l}\text { 5. Field conclusions/recommendations: The site appeared to be in good condifion. } \\
\text { There was no physical damage to the use restriction signage } \\
\text { or T-posts. No corrective actions are necessary. }\end{array}$} \\
\hline \multicolumn{4}{|l|}{ F. CERTIFICATION } \\
\hline \multicolumn{4}{|c|}{$\begin{array}{l}\text { I have conducted an inspection of CAS 20-15-01, Landfill, in accordance with the procedures of the Post-Closure Plan as recorded on this checklist, attached } \\
\text { sheets, field notes, photographs, and photograph logs. }\end{array}$} \\
\hline Chief Inspector's Signature: /s/ Brian Konrad & & Date: & $12 / 11 / 07$ \\
\hline Printed Name: Brian Konrad & & Title: & ER Field Operations Manager \\
\hline
\end{tabular}




\section{POST-CLOSURE INSPECTION CHECKLIST}

\section{CAU 005: LANDFILLS - CAS 23-15-03, DISPOSAL SITE}

\begin{tabular}{ll|l|} 
Inspection Date and Time: $1 / 23 / 08 \quad$ Approx. 3:00 PM & Reason for Inspection: Annual \\
\hline Date of Last Post-Closure Inspection: $12 / 28 / 06$ & Reason for Last Post-Closure Inspection: Annual
\end{tabular}

Responsible Entity: NSTec Environmental Restoration, Nevada Test Site, Mercury, Nevada

Responsible Facility Owner: Jeffrey L. Smith, Deputy Manager, Environmental Restoration

\begin{tabular}{|l|l|}
\hline Chief Inspector: Gleun Richardson & Title: Task Manager \\
\hline Assistant Inspector: Robert Green & Title: Field Technical Lead
\end{tabular}

A. GENERAL INSTRUCTIONS

1. All checklist items must be completed and detailed comments made to document the results of the site inspection. The completed checklist is part of the field record of the inspection. Additional pages should be used as necessary to ensure that a complete record is made. Attach the additional pages and number all pages upon completion of the inspection.

2. Any checklist line item marked by an inspector in a SHADED BOX must be fully explained or an appropriate reference to previous reports provided. The purpose of this requirement is to provide a written explanation of inspector observations and the inspector's rationale for conclusions and recommendations. Explanations are to be placed on additional attachments and cross-referenced appropriately. Explanations, in addition to narrative, will take the form of sketches, measurements, and annotated site maps.

3. The site inspection is a walking inspection of the entire site including the perimeter and sufficient transects to be able to inspect the entire surface and all features specifically described in this checklist.

4. Field notes taken to assist in completion of this checklist will become part of the inspection record. No form is specified for field notes; however, they must be legible and in sufficient detail to enable review by succeeding inspectors and the responsible agency.

5. This unit will be inspected annually with formal reporting to the Nevada Division of Environmental Protection to be done annually. The annual letter report will include a summary with this inspection checklist attached.

\begin{tabular}{|c|c|c|c|}
\hline B. PREPARATION (To be competed prior to site visit) & YES & NO & EXPLANATION (required if shaded box is checked) \\
\hline \multicolumn{4}{|l|}{ 1. Has the Post-Closure Plan been reviewed? } \\
\hline \multicolumn{4}{|l|}{ 2. Have the previous inspection reports been reviewed? } \\
\hline \multicolumn{4}{|l|}{ 3. Were anomalies or trends detected on previous inspections? } \\
\hline \multicolumn{4}{|l|}{$\begin{array}{l}\text { 4. Were maintenance or repair of the landfill unit performed since } \\
\text { the last inspection? }\end{array}$} \\
\hline $\begin{array}{l}\text { a. If yes, has site repair resulted in a change from as-built } \\
\text { conditions? }\end{array}$ & & & $\stackrel{\mathrm{NA}}{\mathrm{V}}$ \\
\hline $\begin{array}{l}\text { b. If yes (to } 4 \mathrm{a} \text { ), are revised as-built plans available that } \\
\text { reflect repair changes? }\end{array}$ & & & NA \\
\hline
\end{tabular}

\section{FACILITY \& UTILITY PLANS REVIEW}

The Post-Closure Plan requires the inspector to confirm that the latest copies of the relevant utility and facility plans include provisions for addressing environmental and safety issues associated with maintaining and repairing utilities and roads within this CAS. The following actively maintained utilities are within this CAS at the following active facilities: (1) The Area 23 Landfill has an access road that crosses this CAS. The road is maintained by landfill personnel. (2) The WSI training facility has a water main that services the fire hydrant for the firing range and roadways that cross the CAS.

Contact the appropriate utility owners, review the appropriate plans, and complete the checklist attached on Page 2.

\section{SITE INSPECTION PREPARATION}

Assemble the following, as needed, to conduct inspections:

a. Radio, pager, etc.

b. Previous letter report, inspection checklists, repair records, and as-built plans

c. Other miscellaneous support equipment 


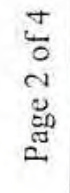

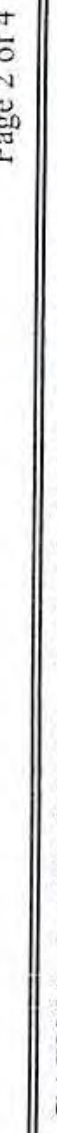




\section{POST-CLOSURE INSPECTION CHECKLIST}

\section{CAU 005: LANDFILLS - CAS 23-15-03, DISPOSAL SITE}

\section{E. SITE INSPECTION}

1. Site markers (Area 23 Landfill):

a. Have any posts been damaged or their anchoring weakened?

b. Are any of the use restriction signs damaged or missing?

c. Are all use restriction signs legible?

d. How many signs need to be replaced?

2. Waste unit cover (Area 23 Landfill):

a. Is there evidence of settling?

b. Is there evidence of erosion (wind or water)?

c. Is there evidence of human intrusion into the cover?

d. Is there evidence of large animal intrusion into the cover?

3. Site markers (WSI Training Facility):

a. Have any posts been damaged or their anchoring weakened?

b. Are any of the use restriction signs damaged or missing?

c. Are all use restriction signs legible?

d. How many signs need to be replaced?

4. Waste unit cover (WSI Training Facility):

a. Is there evidence of settling?

b. Is there evidence of erosion (wind or water)?

c. Is there evidence of human intrusion into the cover?

d. Is there evidence of large animal intrusion into the cover?

5. Photograph Documentation (optional):

a. Have photographs been taken of the site?

If yes, how many photos were taken?

If yes, has a photographic log been prepared?

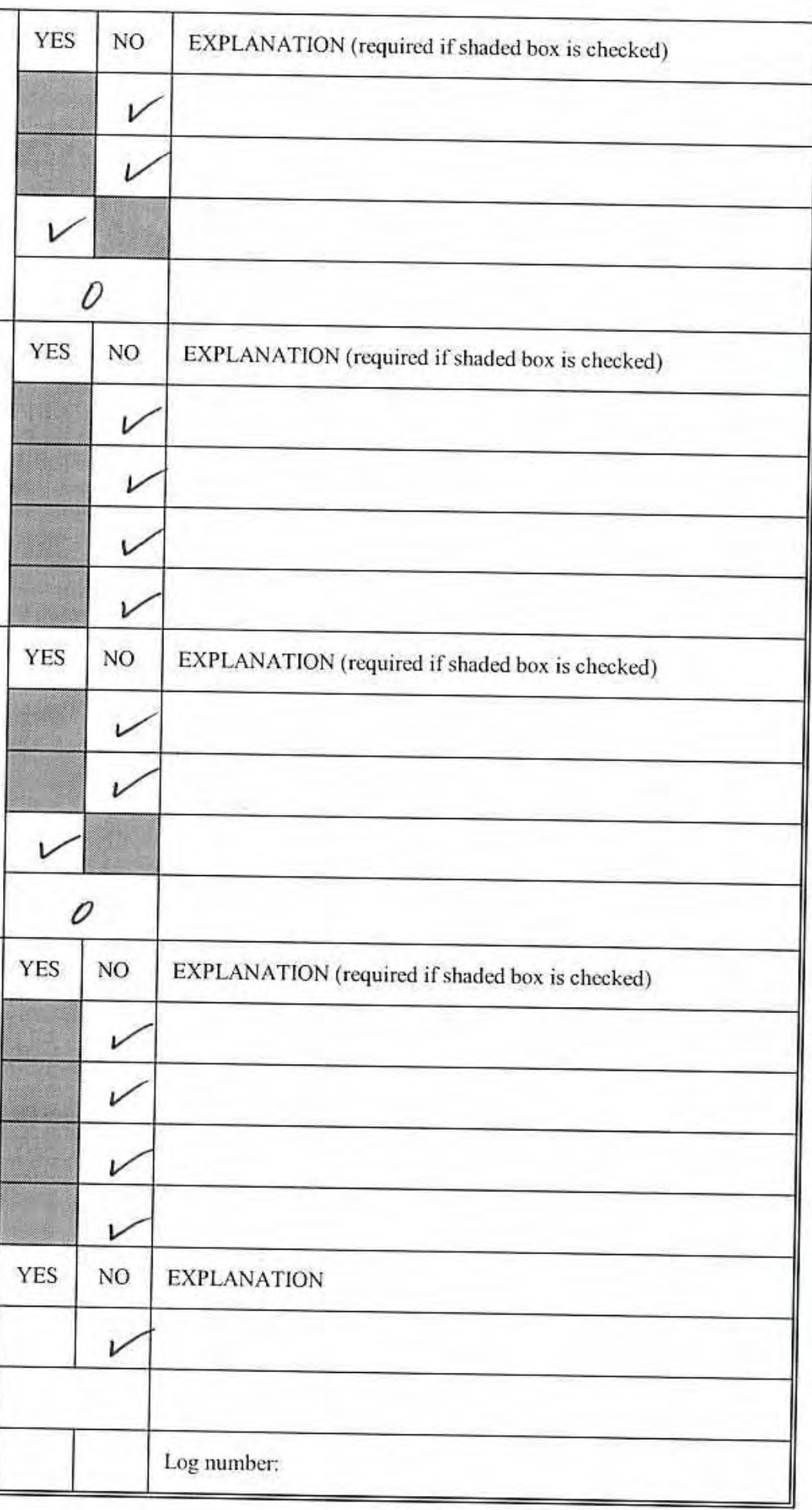




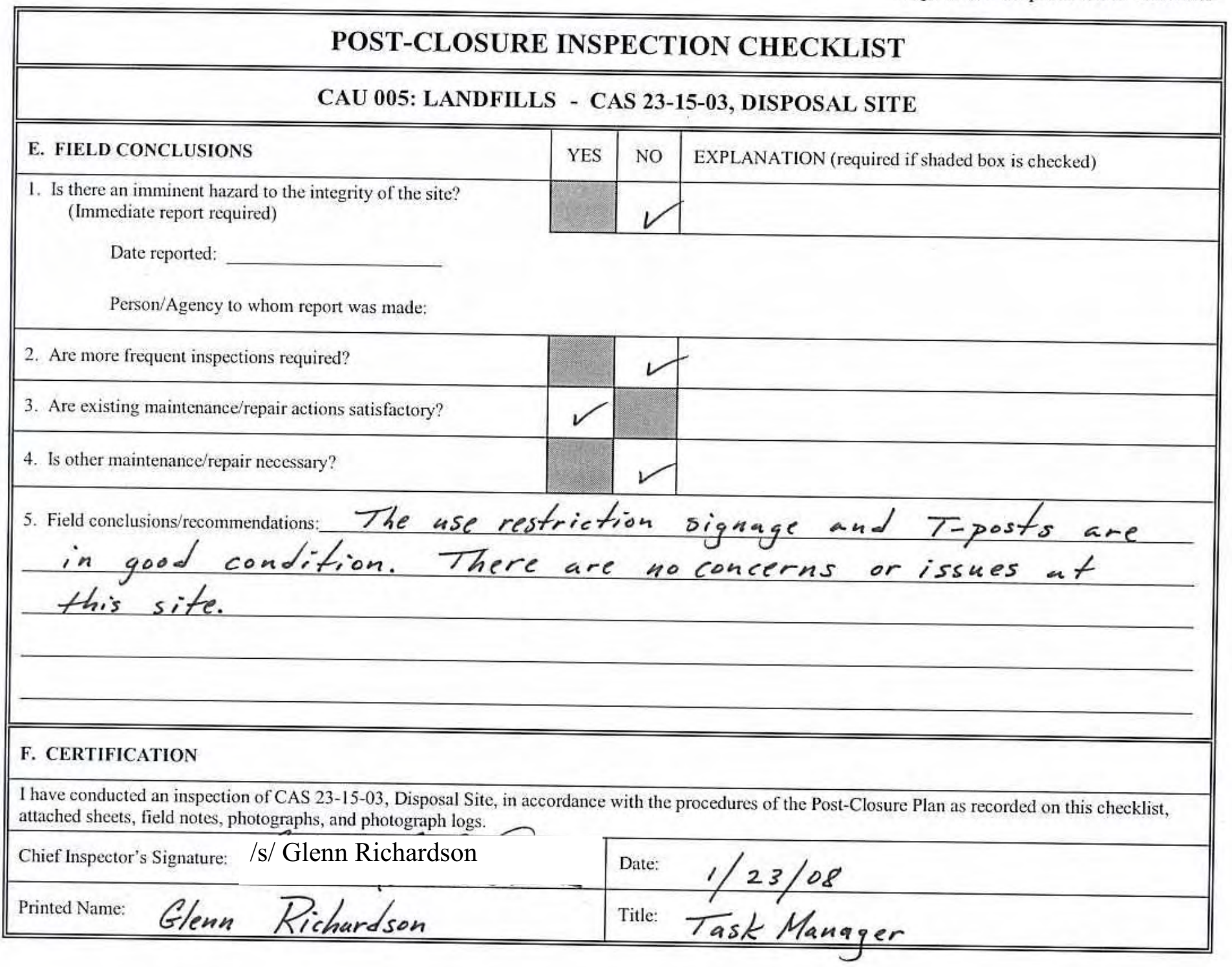


CAU 137: WASTE DISPOSAL SITES 


\section{POST-CLOSURE INSPECTION CHECKLIST}

\section{CAU 137: WASTE DISPOSAL SITES - CAS 01-08-01, WASTE DISPOSAL SITE}

\begin{tabular}{|l|l|}
\hline \hline Inspection Date and Time: $\quad 1 / 16 / 08 \quad 12: 32 \mathrm{PM}$ & Reason for Inspection: Ann ua / \\
\hline Date of Last Post-Closure Inspection: None & Reason for Last Post-Closure Inspection: \\
\hline Re & Non
\end{tabular}

Responsible Entity: NSTec Environmental Restoration, Nevada Test Site, Mercury, Nevada

Responsible Facility Owner: Jeffrey L, Smith, Deputy Manager, Environmental Restoration

\begin{tabular}{|l|l}
\hline Chief Inspector: Glenn Richardson & Title: Task Manager \\
\hline Assistant Inspector: Robert Green & Title: Field Technica/ Lead
\end{tabular}

A. GENERAL INSTRUCTIONS

1. All checklist items must be completed and detailed comments made to document the results of the site inspection. The completed checklist is part of the field record of the inspection. Additional pages should be used as necessary to ensure that a complete record is made. Attach the additional pages and number all pages upon completion of the inspection.

2. Any checklist line item marked by an inspector in a SHADED BOX must be fully explained or an appropriate reference to previous reports provided. The purpose of this requirement is to provide a written explanation of inspector observations and the inspector's rationale for conclusions and recommendations. Explanations are to be placed on additional attachments and cross-referenced appropriately. Explanations, in addition to narrative, will take the form of sketches, measurements, and annotated site maps.

3. The site inspection is a walking inspection of the entire site including the perimeter and sufficient transects to be able to inspect the entire surface and all features specifically described in this checklist.

4. Field notes taken to assist in completion of this checklist will become part of the inspection record. No form is specified for field notes; however, they must be legible and in sufficient detail to enable review by succeeding inspectors and the responsible agency.

5. This unit will be inspected annually with formal reporting to the Nevada Division of Environmental Protection to be done annually. The annual letter report will include a summary with this inspection checklist attached.

\begin{tabular}{|c|c|c|c|}
\hline B. PREPARATION (To be competed prior to site visit) & YES & NO & EXPLANATION (required if shaded boxischecked) \\
\hline 1. Has the Post-Closure Plan been reviewed? & & & \\
\hline 2. Have the previous inspection reports been reviewed? & & & \\
\hline 3. Were anomalies or trends detected on previous inspections? & & & \\
\hline 4. Were maintenance or repairs performed since last inspection? & & & \\
\hline
\end{tabular}

\section{SITE INSPECTION PREPARATION}

Assemble the following, as needed, to conduct inspections:

a. Radio, pager, etc.

b. Previous letter report, inspection checklists, repair records, and as-built plans

c. Other miscellaneous support equipment

\section{SITE INSPECTION}

1. Site markers:

a. Is there damage to the fence?

b. Have any posts been damaged or their anchoring weakened?

c. Are any of the 10 use restriction signs damaged or missing?

d. Are all use restriction signs legible?

e. How many signs need to be replaced?

\begin{tabular}{|c|c|l||}
\hline YES & NO & EXPLANATION (required if shaded box is checked) \\
\hline & & \\
\hline & & \\
\hline & & \\
\hline & & \\
\hline & & \\
\hline
\end{tabular}




\section{POST-CLOSURE INSPECTION CHECKLIST}

\section{CAU 137: WASTE DISPOSAL SITES - CAS 01-08-01, WASTE DISPOSAL SITE}

2. Photograph Documentation (optional):

a. Have photographs been taken of the site?

If yes, how many photos were taken?

If yes, has a photographic log been prepared?

\begin{tabular}{|c|c|c|}
\hline E. FIELD CONCLUSIONS & YES & NO \\
\hline 1. Are more frequent inspections required & & \\
\hline 2. Are existing maintenance/repair actions & & \\
\hline 3. Is other maintenance/repair necessary? & & \\
\hline
\end{tabular}

4. Field conclusionsirecommendations: The integrity of the fencing is intact. The use restriction signage is legible and in good condition. There are no issues at this site that warrants a corrective action.

\section{F. CERTIFICATION}

I have conducted an inspection of CAS 01-08-01, Waste Disposal Site, in accordance with the procedures of the Post-Closure Plan as recorded on this checklist, attached sheets, field notes, photographs, and photograph logs.

Chief Inspector's Signature: /s/ Glenn Richardson Printed Name: Glenn Richardson Date: $1 / 16 / 08$
Title: Task Manager 


\section{POST-CLOSURE INSPECTION CHECKLIST}

\section{CAU 137: WASTE DISPOSAL SITES - CAS 07-23-02, RADIOACTIVE WASTE DISPOSAL SITE}

\begin{tabular}{||l|l|}
\hline Inspection Date and Time: $1 / 16 / 08$ & Reason for Inspection: Annua $/ 12 \mathrm{PM}$ \\
\hline Date of Last Post-Closure Inspection: None & Reason for Last Post-Closure Inspection: \\
\hline
\end{tabular}

Responsible Entity: NSTec Environmental Restoration, Nevada Test Site, Mercury, Nevada

Responsible Facility Owner: Jeffrey L. Smith, Deputy Manager, Environmental Restoration

\begin{tabular}{|l|l}
\hline Chief Inspector: Glenn Richardson & Title: Task Manager \\
\hline Assistant Inspector: Robert Green & Title: Field Technical
\end{tabular}

A. GENERAL INSTRUCTIONS

1. All checklist items must be completed and detailed comments made to document the results of the site inspection. The completed checklist is part of the field record of the inspection. Additional pages should be used as necessary to ensure that a complete record is made. Attach the additional pages and number all pages upon completion of the inspection.

2. Any checklist line item marked by an inspector in a SHADED BOX must be fully explained or an appropriate reference to previous reports provided. The purpose of this requirement is to provide a written explanation of inspector observations and the inspector's rationale for conclusions and recommendations. Explanations are to be placed on additional attachments and cross-referenced appropriately. Explanations, in addition to narrative, will take the form of sketches, measurements, and annotated site maps.

3. The site inspection is a walking inspection of the entire site including the perimeter and sufficient transects to be able to inspect the entire surface and all features specifically described in this checklist.

4. Field notes taken to assist in completion of this checklist will become part of the inspection record. No form is specified for field notes; however, they must be legible and in sufficient detail to enable review by succeeding inspectors and the responsible agency.

5. This unit will be inspected annually with formal reporting to the Nevada Division of Environmental Protection to be done annually. The annual letter report will include a summary with this inspection checklist attached.

\begin{tabular}{|l|l|l|l|}
\hline B. PREPARATION (To be competed prior to site visit) & YES & NO & EXPLANATION (required if shaded box is checked) \\
\hline 1. Has the Post-Closure Plan been reviewed? & & & \\
2. Have the previous inspection reports been reviewed? & & &
\end{tabular}

\section{SITE INSPECTION PREPARATION}

Assemble the following, as needed, to conduct inspections:

a. Radio, pager, etc.

b. Previous letter report, inspection checklists, repair records, and as-built plans

c. Other miscellaneous support equipment

\section{SITE INSPECTION}

1. Site markers:

a. Is there damage to the fence?

b. Have any posts been damaged or their anchoring weakened?

c. Are any of the 6 use restriction signs damaged or missing?

d. Are all use restriction signs legible?

c. How many signs need to be replaced?

\begin{tabular}{|l|l|l|}
\hline YES & NO & EXPLANATION (required if shaded box is checked) \\
\hline & & \\
\hline & & \\
\hline & & \\
\hline & & \\
\hline & & \\
\hline
\end{tabular}




\section{POST-CLOSURE INSPECTION CHECKLIST}

\section{CAU 137: WASTE DISPOSAL SITES - CAS 07-23-02, RADIOACTIVE WASTE DISPOSAL SITE}

2. Photograph Documentation (optional):

a. Have photographs been taken of the site?

If yes, how many photos were taken?

If yes, has a photographic log been prepared?

\section{E. FIELD CONCLUSIONS}

1. Are more frequent inspections required?

2. Are existing maintenance/repair actions satisfactory?

3. Is other maintenance/repair necessary?

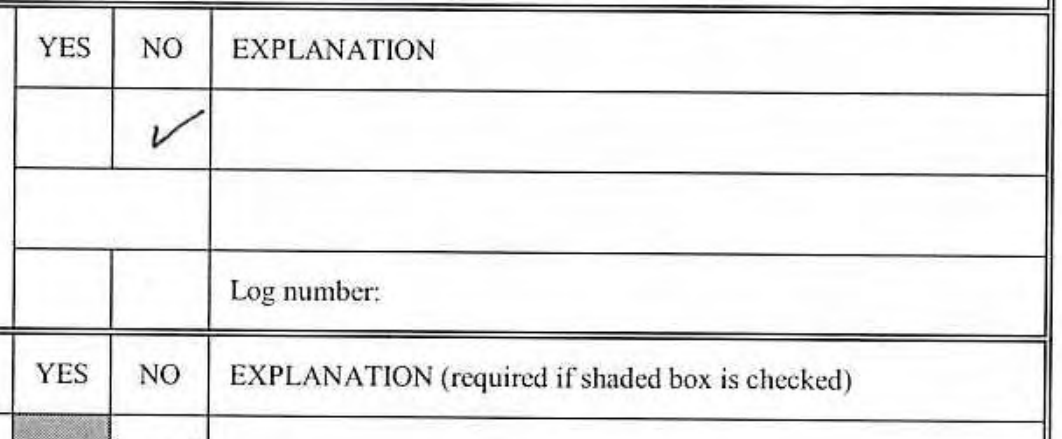

4. Field conclusions/recommendations: Drove around use restriction site boundary. The integrity of the fencing and the signage are in excellent condition. There is no evidence of intrusion or physical damage due to high winds within the general area.

\section{F. CERTIFICATION}

I have conducted an inspection of CAS 07-23-02, Radioactive Waste Disposal Site, in accordance with the procedures of the Post-Closure Plan as recorded on this checklist, attached sheets, ficld notes, photographs, and photograph logs.

Chief Inspector's Signature: /s/ Glenn Richardson

Printed Name:

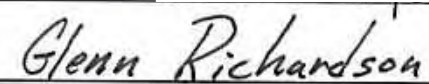

- Date: $1 / 16 / 08$
Title: Task Manager




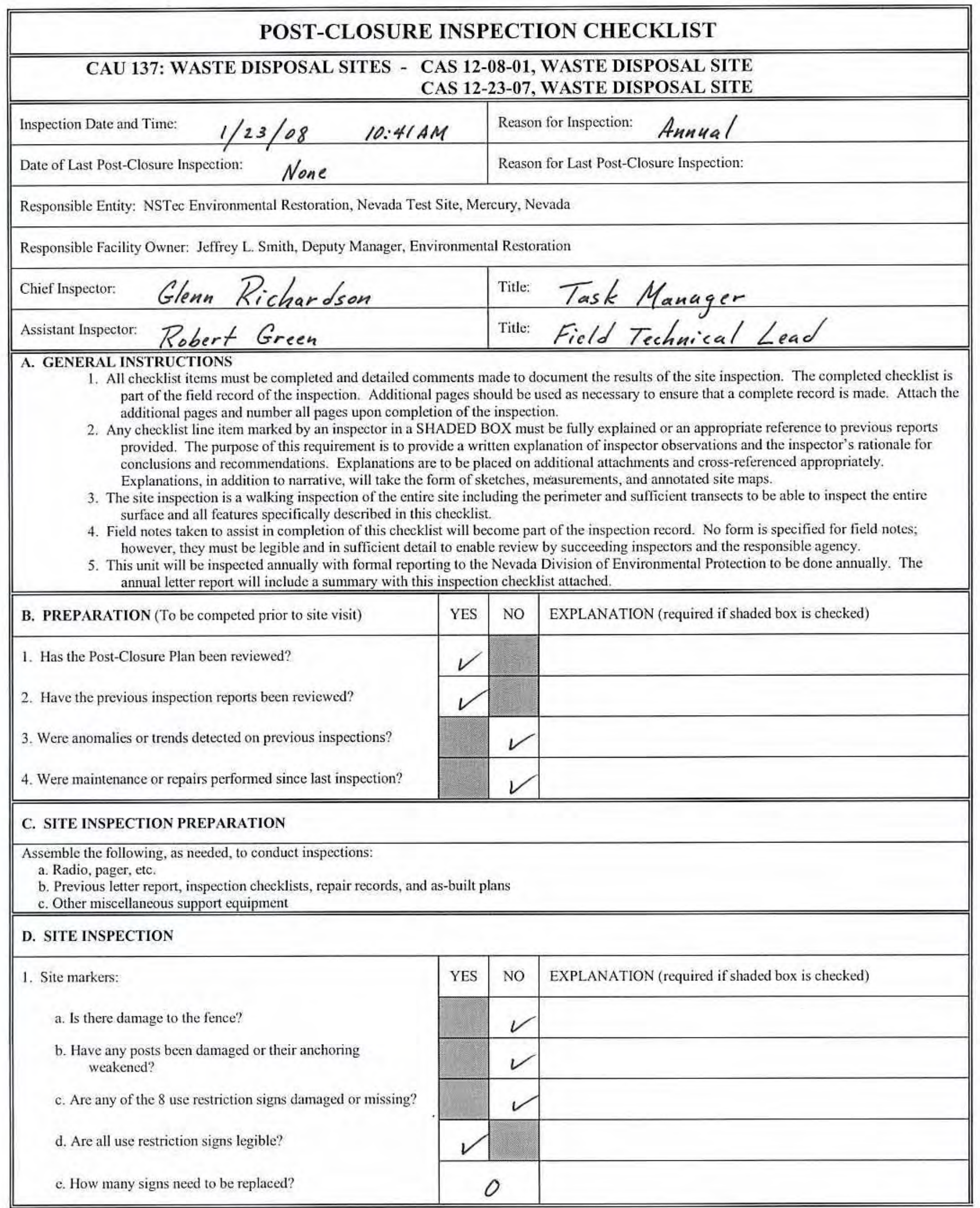




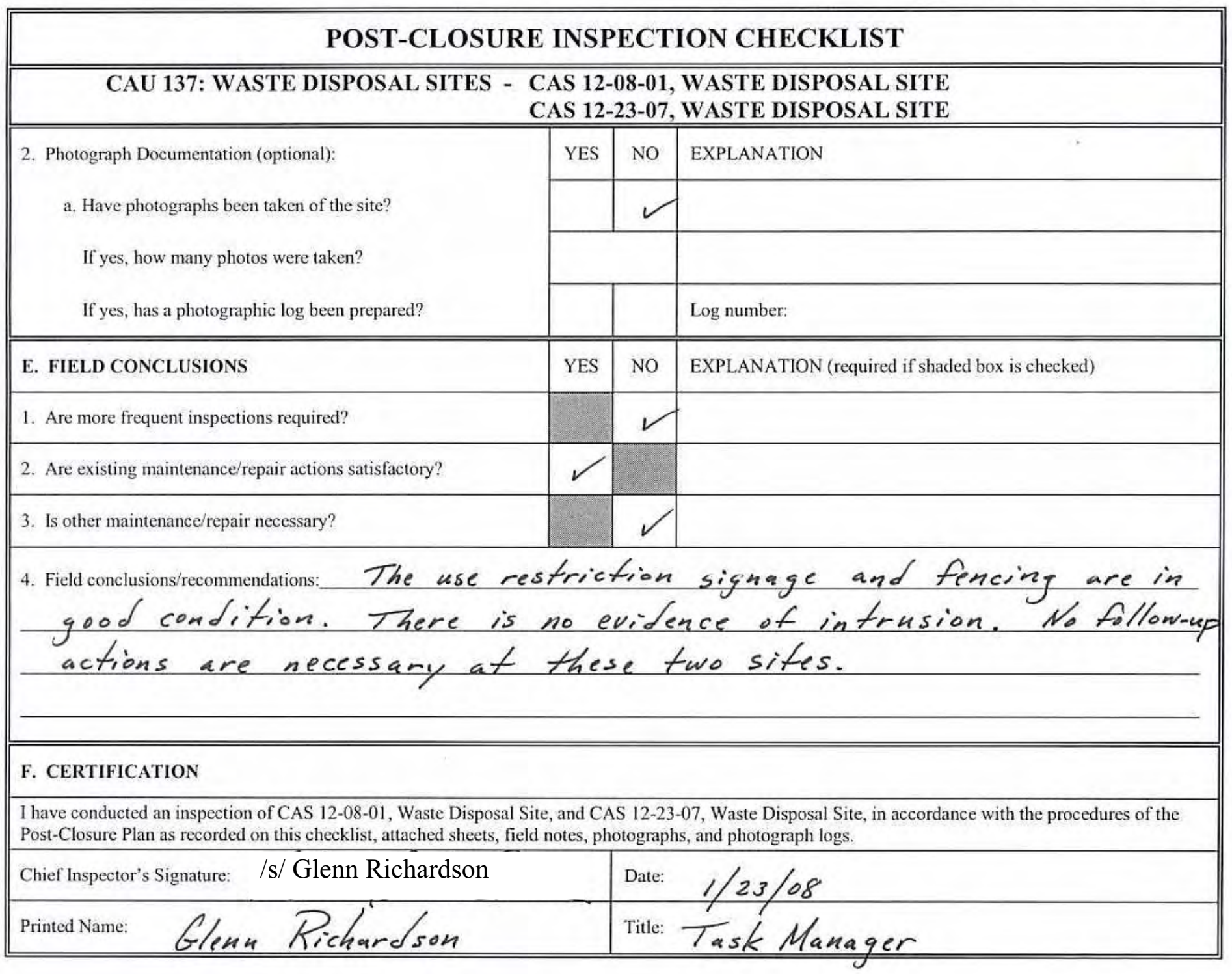


CAU 140: WASTE DUMPS, BURN PITS, AND STORAGE AREA 


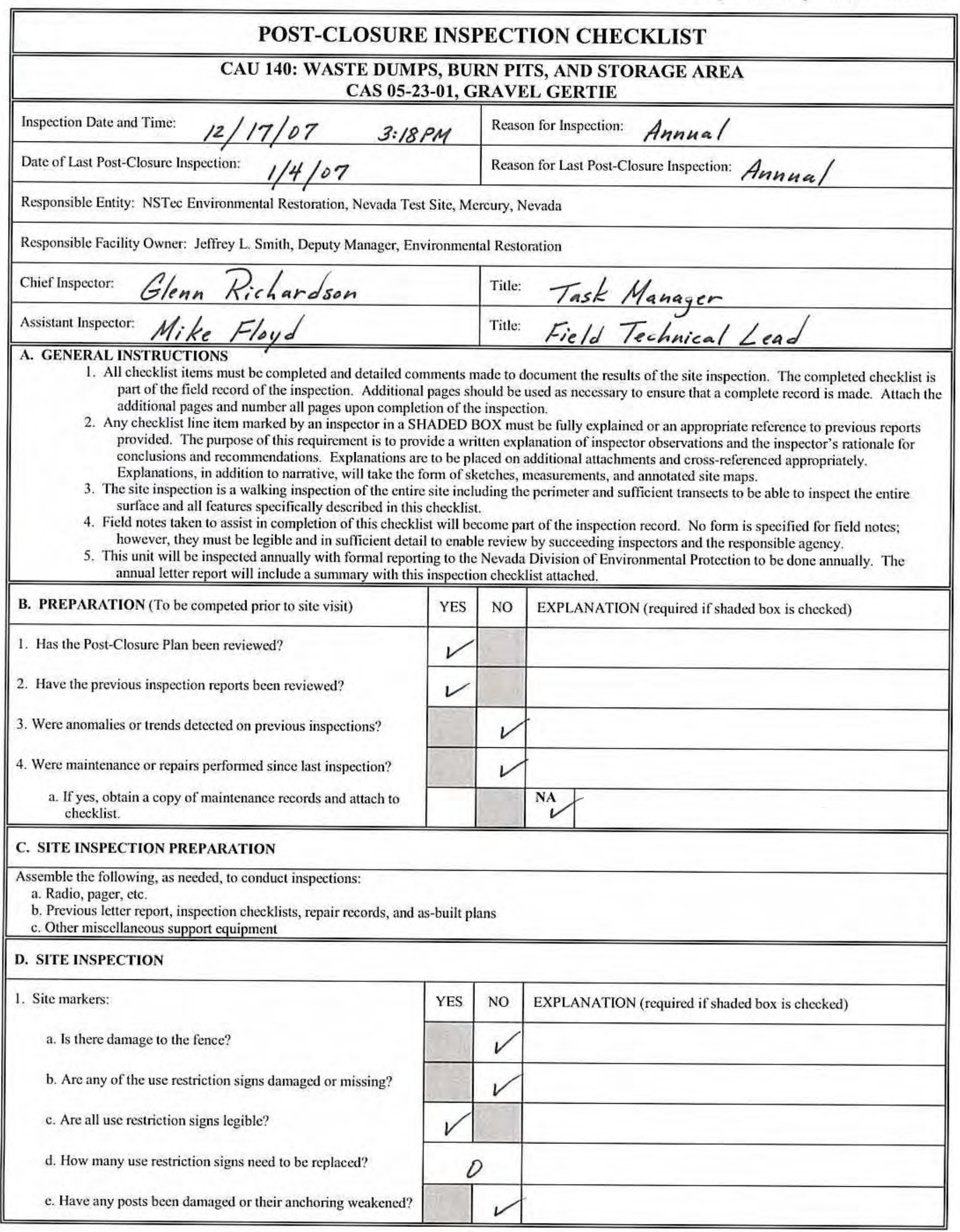




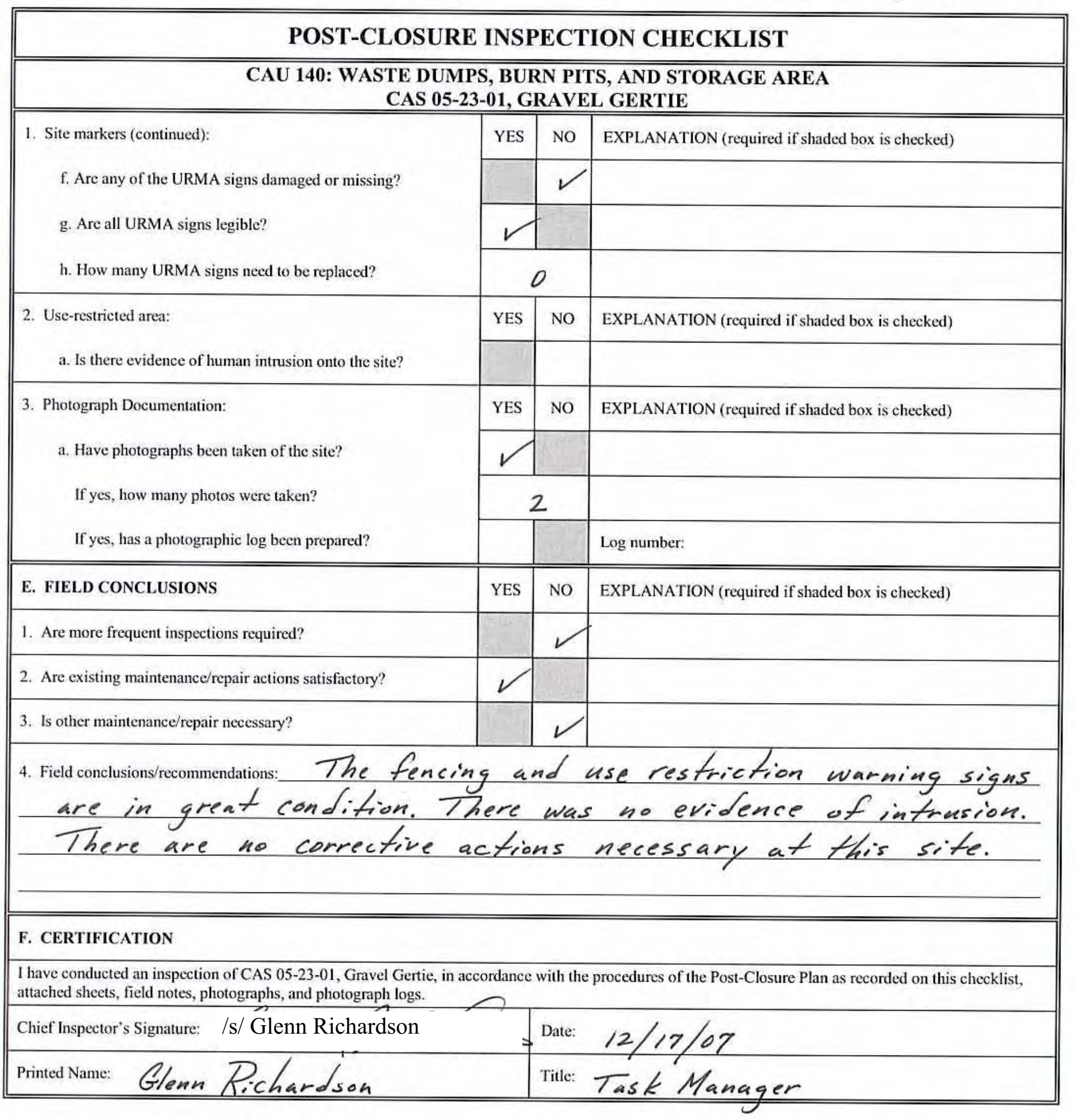

Attachments (check if attached):
$\square$ Maintenance records
$\square$ Photos
■ Field Notes 
CAU 140, Waste Dumps, Burn Pits, and Storage Area

CAS 05-23-01, GRAVEL GerTIE

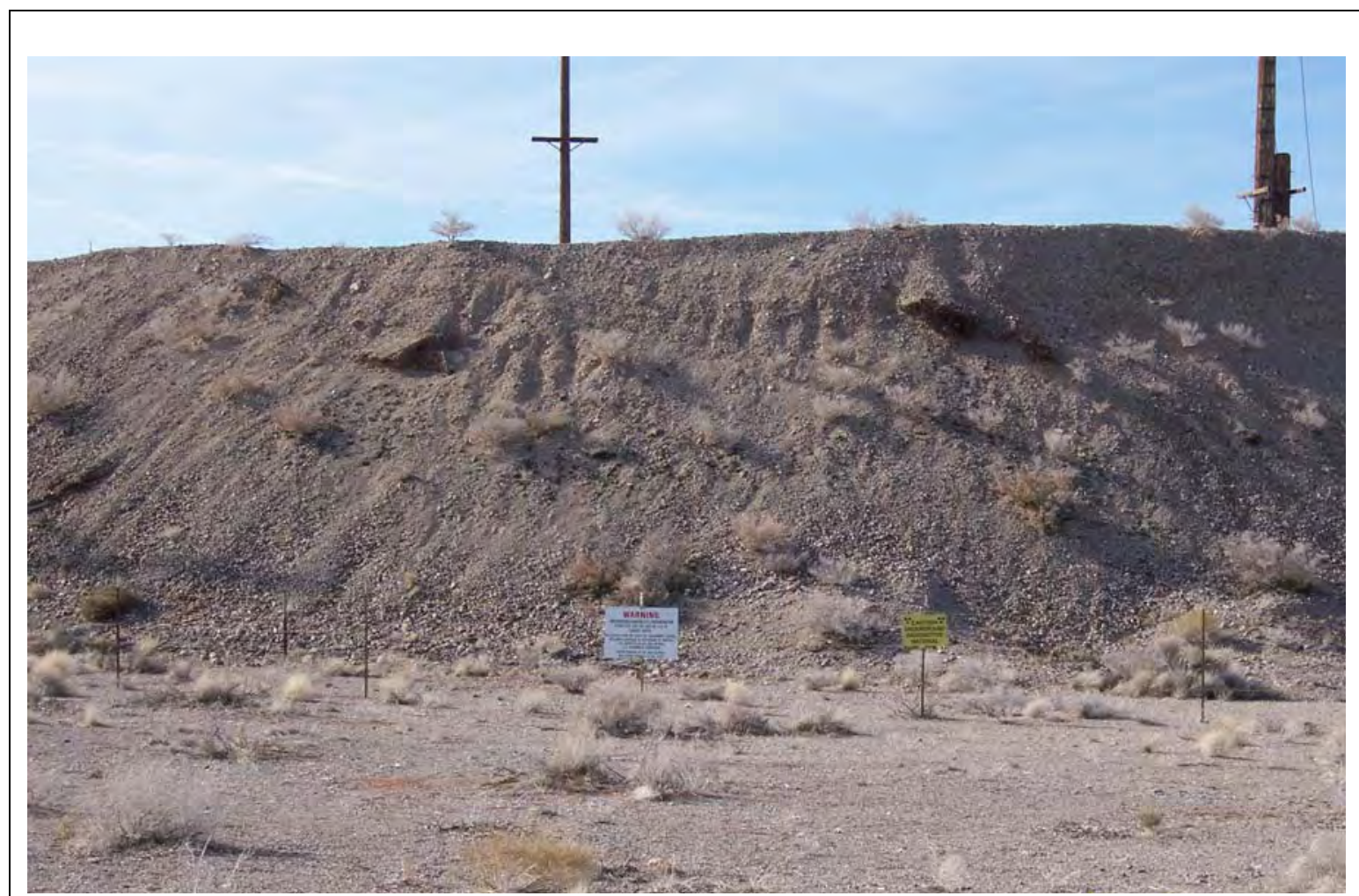

$12 / 17 / 2007$

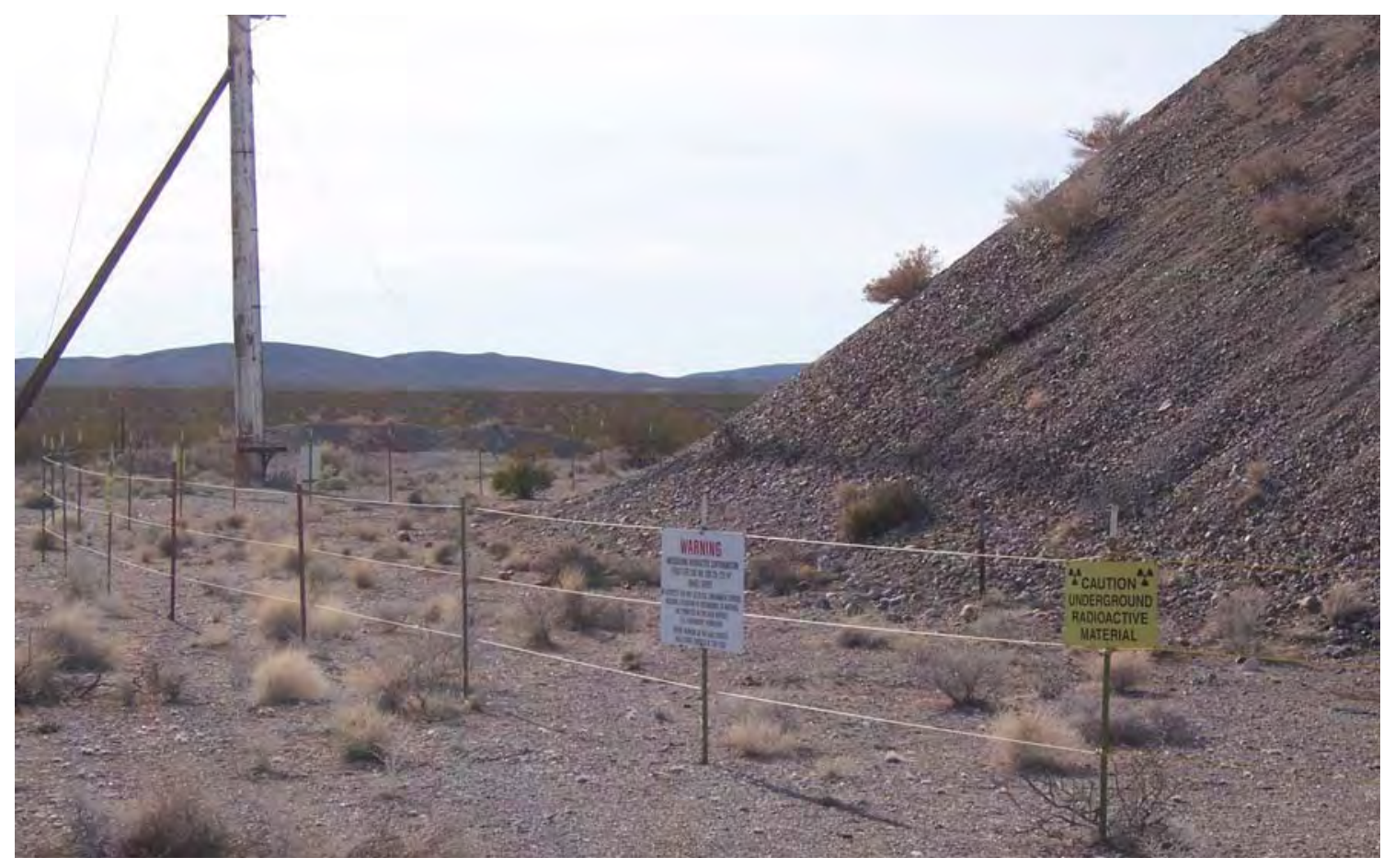

$12 / 17 / 2007$ 
26

PROJECT NO.

TITLE

BOOK NO.

Work continued from Page 25

CAM 254

CAS 25-23-06. Arrived@ the site at 11:194M. All T-posts an use restriction signage are in good condition. There are no concerns or issues at this site. Leaving the site af $11: 26 \mathrm{AM}$.

CAL 140 Arrived $P$ Note:

LAS OS-23-OI

Resumed inspections after lunch and All-hands meeting.

The fencing and use restriction warning signs are in good condition. There appears to be no intrusion at the site location. There are no followup actions required at this site. Leaving the site at 3:33 PM.

CAL. 204

CAS 05-33-01 Arrived (2) the site at 3:42 PM. The wire rope fencing and $U R$ signage are in good condition. The radiological postings are not damaged and remain legible. There appears to be no intrusion at the site. This site has no issues. Leaving the site at 3:51 PM.

CAL 204

CAS 05-18-02 Arrived @ the site at 3:56 PM. The wire rape and chaim-link fencing are in great condition. Signs are erect and legible. Noticed an empty drum, extra T-posts, and sandbags that were possibly omitted (inadvertaitly) during site demobilization. Based upon the visual site inspection, the post closure requirements are maintained. Housekeeping activities could be performed as a bout management practice. Leaving the site at $4: 05$ pm.

w.scientificbindery88yrs.com

IGNATURE

Work continued to Page 27

ISCLOSED TO AND UNDERSTOOD BY

DATE

DATE

$12 / 17 / 07$ 


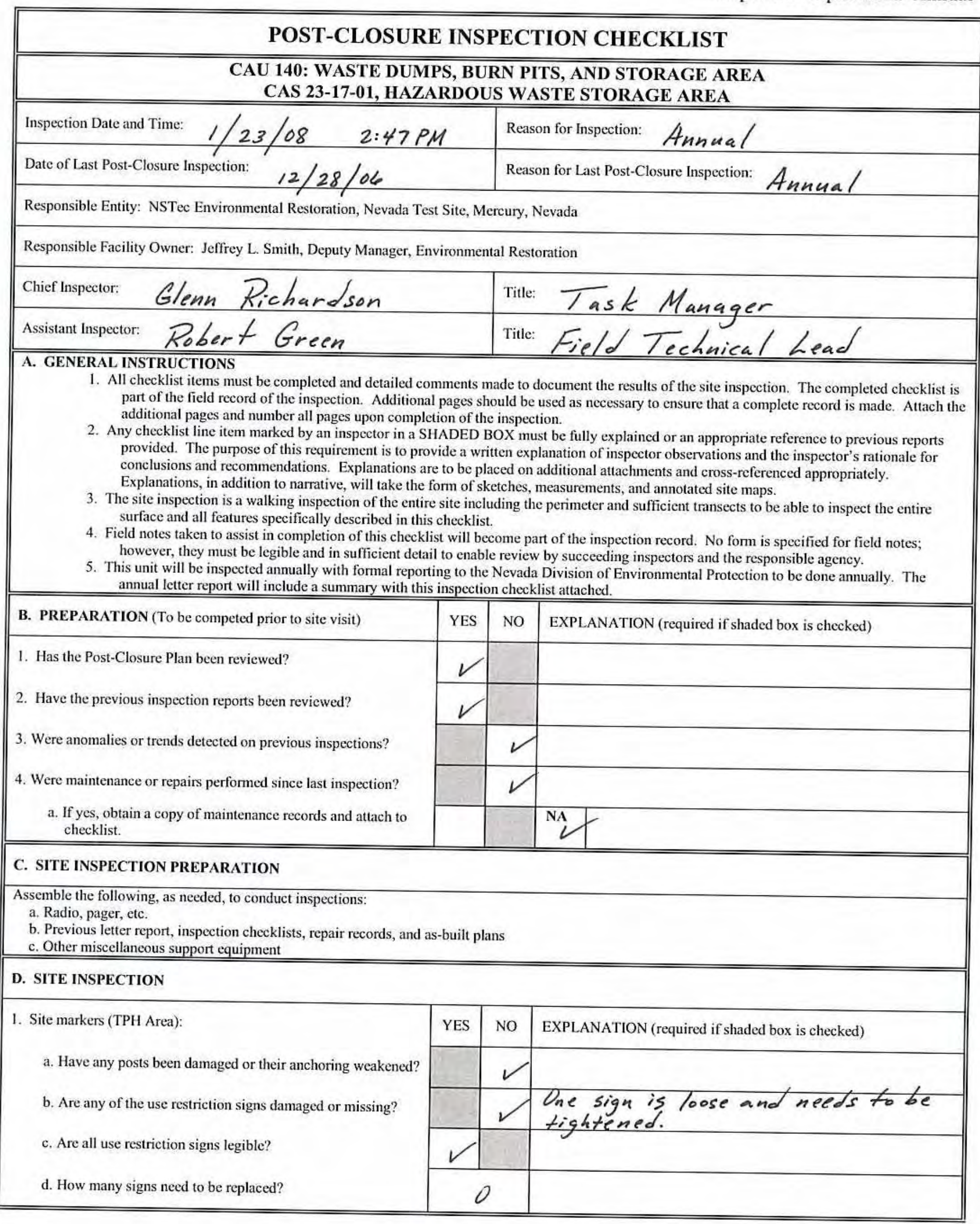




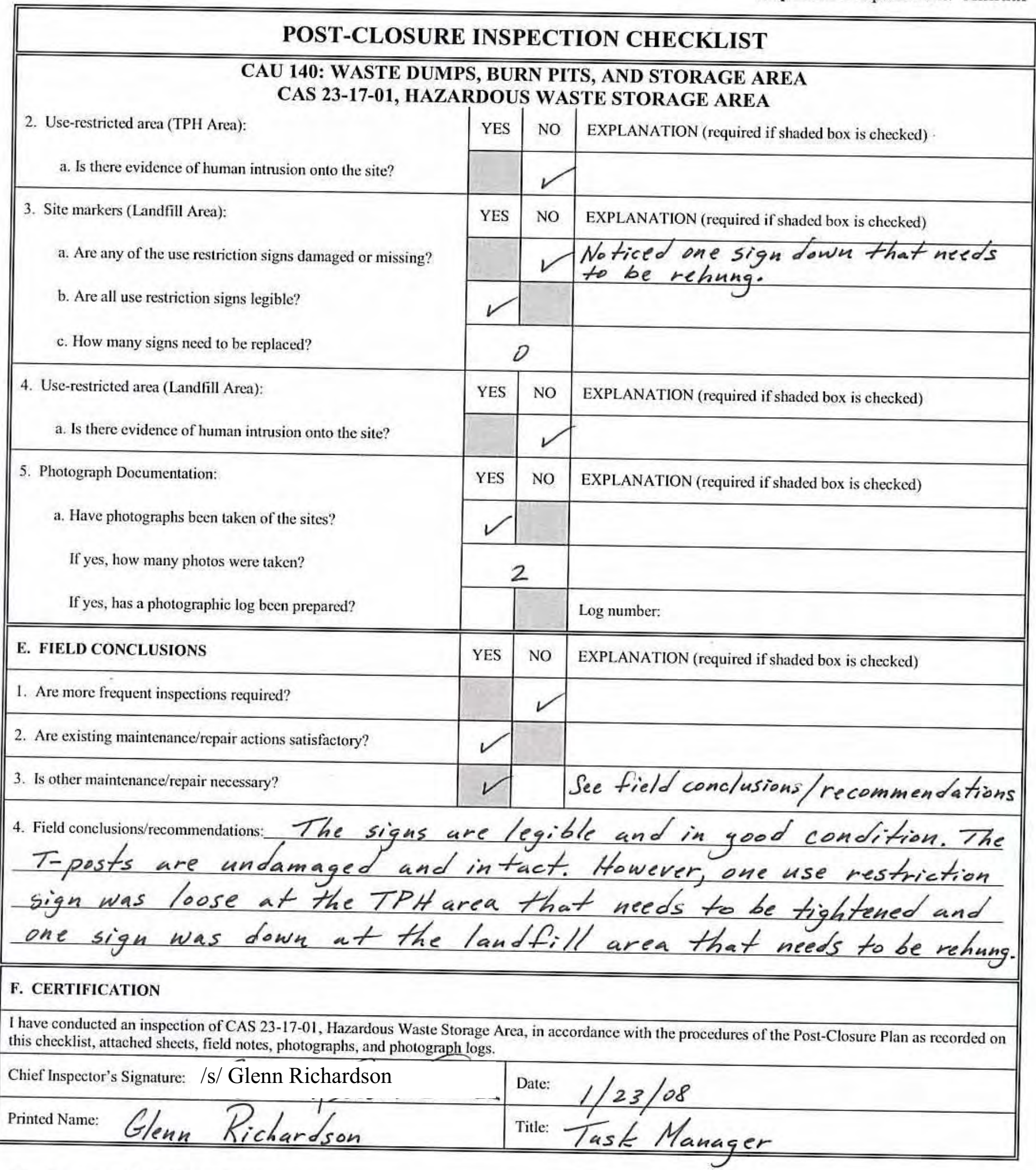

Attachments (check if attached):

$\square$ Maintenance records

$\square$ Photos

ㅁ. Field notes 
CAU 140, Waste Dumps, Burn Pits, and Storage Area CAS 23-17-01, Hazardous Waste Storage Area

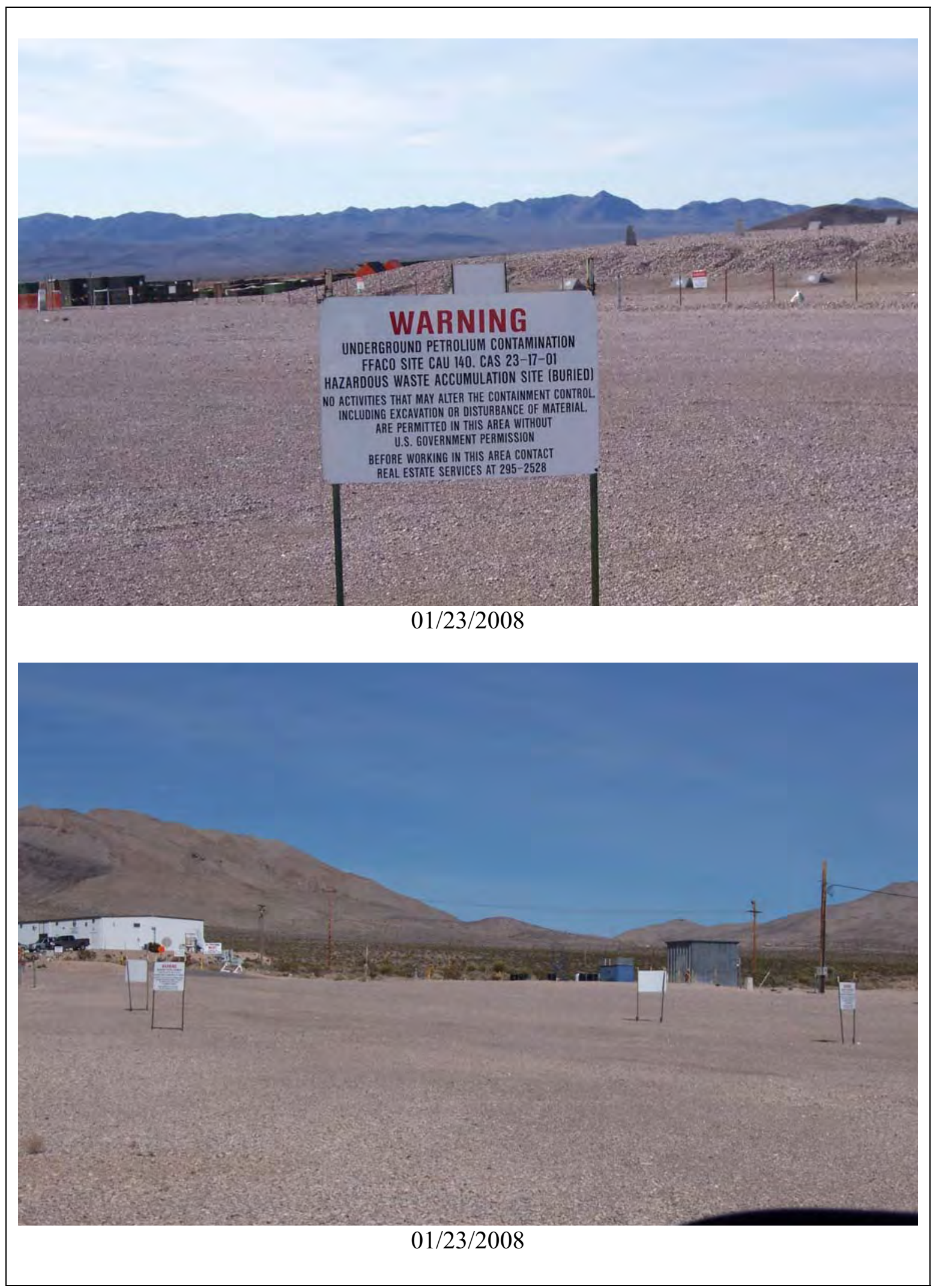


44

PROJECT NO.

TITLE

BOOK NO.

Work continued from Page 33

in the future. Leaving access pathway (restricted) for (A4 55) sites at 11:58 AM. Access Gate 12-8C is the Physical Barricade Point.

CAL 309

CAS 12-06-09/CAS 12-06-05. These two sites could not be accessed due to a physical barrier (locked) in place. Ia the future, a key will need to be retrieved from NNSA SOC for access. Leaving the Area 12 barrier at 12:33 PM.

CAN 005

CAS 05-16-01 Arrived @ RWMS Office Trailer to request site access (2)1:3 0PM. Arrived@ the site @1:54 PM. Signage and postings are in good condition and undamaged. Discovered two $U R$ signs down that need to be rehung on the east side of the flood dike (berm). The fencing on the west side of the flood dike $\frac{i s}{4 x}$ in good condition. Signage is in place and legible. The only corrective action necessary is on the east side of the berm at these sites. Leaving this site at 2:16 PM.

CAM 342

CAS 23-56-01 Arrived (2) site at 2:38 PM. The signage and fencing are in great condition. Verified the contact number reaches an NNSA extension for service or information. There are no issues on concerns at this site. Leaving this site at $2: 43 \mathrm{PM}$.

CAU 1 40

CHs 23-17-01 Arrived (e) the site at 2:47 PM. The signage and postings are in tact and in excellent condition. Correction: One sign is loose scientificbindery88yrs.com

Work continued to Page 35

NATURE /s/ Glenn Richardson

DATE

CLOSED TO AND UNDERSTOOD BY

$1 / 23 / 08$ 
TITLE

Work continued from Page 34

PROJECT NO.

BOOK NO.

(TH)

and needs to be tightened. This is the square ute boundary due east of the Area 23 Haze. Waste Trenches. The signage and postings

further south in the rectangular shaped b boundary are stable and in great condition, but noticed one sign was down that needs rehanging.

5

CAM 005

CAS 23-15-03 Arrived $P$ the site and checked in at the w SI office trailer prior to performing the inspection. The signage and postings are in excellent condition. No followup actions 10 necessary at this site. Leaving the site at 3:08 PM.

CAL 554

CAS 23-02-08 Arrived@ the site at 3:22 PM. The signage and postings are in excellent condition. There is no potential for damage with 15 the method of how the UR signs and posts were installed. No issues on concerns at this site. Leaving the site at $3.25 \mathrm{PM}$.

20

/s/ Glenn Richardson

$1 / 23 / 08$

25

www.scientificbindery88yrs.com

SIGNATURE

Work continued to Page

DISCLOSED TO AND UNDERSTOOD BY

DATE

WITNESS

DATE

DATE 
CAU 143: AREA 25 CONTAMINATED WASTE DUMPS 


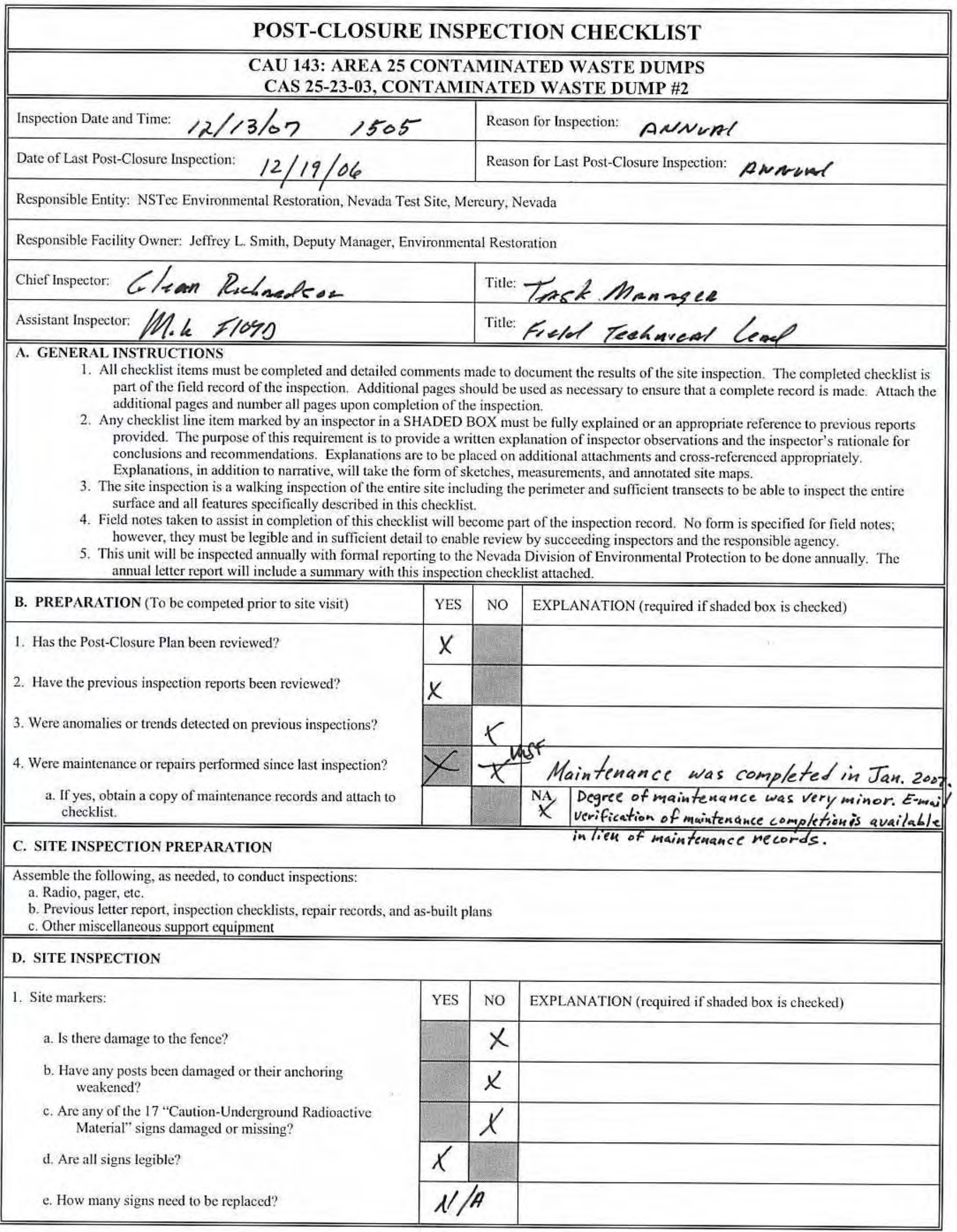




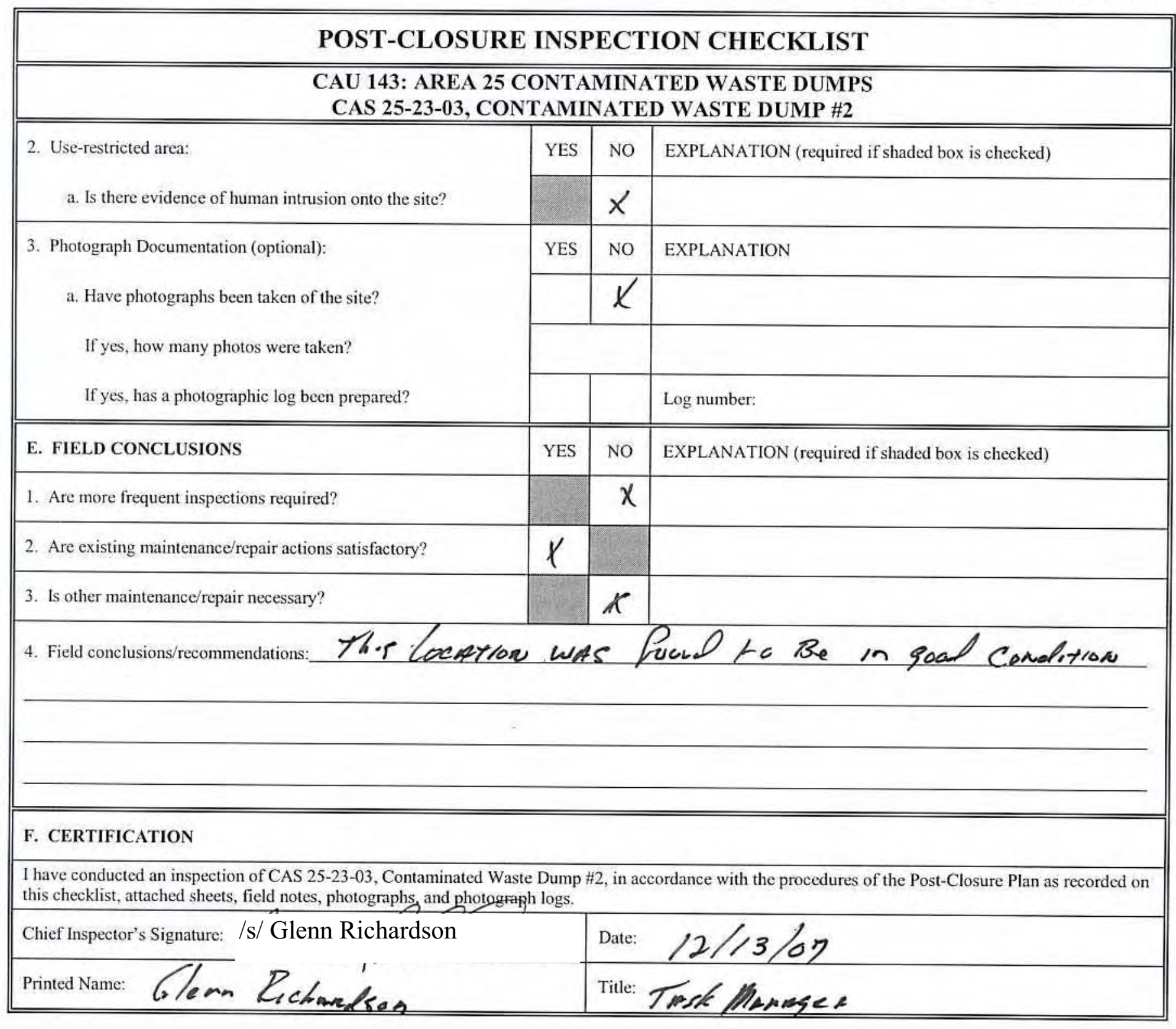

$\square$ Attachment: Maintenance records (check if attached) 


\section{POST-CLOSURE INSPECTION CHECKLIST}

\section{CAU 143: AREA 25 CONTAMINATED WASTE DUMPS CAS 25-23-09, CONTAMINATED WASTE DUMP \#1}

\begin{tabular}{|l|l|}
\hline \hline Inspection Date and Time: 12/13/07 4:03 PM & Reason for Inspection: An nual \\
\hline Date of Last Post-Closure Inspection: $12 / 19 / 06$ & Reason for Last Post-Closure inspection: An una/
\end{tabular}

Responsible Entity: NSTec Environmental Restoration, Nevada Test Site, Mercury, Nevada

Responsible Facility Owner: Jeffrey L. Smith, Deputy Manager, Environmental Restoration

\begin{tabular}{|l|l||}
\hline Chief Inspector: Glenn Richardson & Title: Task Manager \\
\hline Assistant Inspector: Mike Floyd & Title: Field Technica/ Lead \\
\hline \hline
\end{tabular}

A. GENERAL INSTRUCTIONS

1. All checklist items must be completed and detailed comments made to document the results of the site inspection. The completed checklist is part of the field record of the inspection. Additional pages should be used as necessary to ensure that a complete record is made. Attach the additional pages and number all pages upon completion of the inspection.

2. Any checklist line item marked by an inspector in a SHADED BOX must be fully explained or an appropriate reference to previous reports provided. The purpose of this requirement is to provide a written explanation of inspector observations and the inspector's rationale for conclusions and recommendations. Explanations are to be placed on additional attachments and cross-referenced appropriately. Explanations, in addition to narrative, will take the form of sketches, measurements, and annotated site maps.

3. The site inspection is a walking inspection of the entire site including the perimeter and sufficient transects to be able to inspect the entire surface and all features specifically described in this checklist.

4. Field notes taken to assist in completion of this checklist will become part of the inspection record. No form is specified for field notes; however, they must be legible and in sufficient detail to enable review by succeeding inspectors and the responsible agency.

5. This unit will be inspected annually with formal reporting to the Nevada Division of Environmental Protection to be done annually. The annual letter report will include a summary with this inspection checklist attached.

B. PREPARATION (To be competed prior to site visit)

1. Has the Post-Closure Plan been reviewed?

2. Have the previous inspection reports been reviewed?

3. Were anomalies or trends detected on previous inspections?

4. Were maintenance or repairs performed since last inspection?

a. If yes, obtain a copy of maintenance records and attach to checklist.

\begin{tabular}{|l|l|l||}
\hline YES & NO & EXPLANATION (required if shaded box is checked) \\
\hline & & \\
\hline & & \\
\hline & $\checkmark$ & \\
\hline & & \\
\hline
\end{tabular}

\section{SITE INSPECTION PREPARATION}

Assemble the following, as needed, to conduct inspections:

a. Radio, pager, etc.

b. Previous letter report, inspection checklists, repair records, and as-built plans

c. Other miscellaneous support equipment

\section{SITE INSPECTION}

1. Site markers:

a. Is there damage to the fence?

b. Have any posts been damaged or their anchoring weakened?

c. Are any of the 9 use restriction signs damaged or missing?

d. Are all use restriction signs legible?

e. How many use restriction signs need to be replaced?

\begin{tabular}{|c|c|c|}
\hline YES & NO & EXPLANATION (required if shaded box is checked) \\
\hline & $\checkmark$ & \\
\hline & & $\begin{array}{l}\text { S })_{x}(6) \text { UR signs will require a corrective action. } \\
\text { (Three are down, two are loose, and one is missing.) }\end{array}$ \\
\hline V & & \\
\hline & & $\begin{array}{l}\text { one UR sign needs to be replaced; however, 3signs } \\
\text { need to be rehung and } 2 \text { signs need tobe tightenee }\end{array}$ \\
\hline
\end{tabular}




\begin{tabular}{|c|c|c|c|}
\hline \multicolumn{4}{|c|}{ POST-CLOSURE INSPECTION CHECKLIST } \\
\hline \multicolumn{4}{|c|}{$\begin{array}{l}\text { CAU 143: AREA } 25 \text { CONTAMINATED WASTE DUMPS } \\
\text { CAS 25-23-09, CONTAMINATED WASTE DUMP \#1 } \\
\end{array}$} \\
\hline \multirow{3}{*}{$\begin{array}{l}\text { 1. Site markers (continued): } \\
\text { f. Are any of the } 19 \text { "Caution- Radioactive Material" (RMA) } \\
\text { signs damaged or missing? }\end{array}$} & YES & NO & EXPLANATION (required if shaded box is checked) \\
\hline & & & $\begin{array}{l}\text { I RMA sign is down inside the Contaminated } \\
\text { Waste Dump fenced area. }\end{array}$ \\
\hline & & & \\
\hline h. How many RMA signs need to be replaced? & \multicolumn{2}{|c|}{0} & I RMA sign will need to be rehung. \\
\hline $\begin{array}{l}\text { i. Are any of the } 41 \text { "Caution-Underground Radioactive } \\
\text { Material" (URMA) signs damaged or missing? }\end{array}$ & & $\checkmark$ & $\begin{array}{l}2 \text { URMA signs are down. ( } 1 \text { is down anlong the south } \\
\text { side of the West Trenche fence and / is down }\end{array}$ \\
\hline j. Are all URMA signs legible? & & & Along the East side of the CWD fence.) \\
\hline k. How many URMA signs need to be replaced? & \multicolumn{2}{|c|}{0} & \\
\hline \multirow{2}{*}{$\begin{array}{l}\text { 2. Use-restricted area: } \\
\text { a. Is there evidence of human intrusion onto the site? }\end{array}$} & YES & NO & EXPLANATION (required if shaded box is checked) \\
\hline & & & \\
\hline 3. Photograph Documentation (optional): & YES & NO & EXPLANATION \\
\hline \multicolumn{4}{|l|}{ a. Have photographs been taken of the site? } \\
\hline \multicolumn{4}{|l|}{ If yes, how many photos were taken? } \\
\hline If yes, has a photographic log been prepared? & & & Log number: \\
\hline E. FIELD CONCLUSIONS & YES & NO & EXPLANATION (required if shaded box is checked) \\
\hline \multicolumn{4}{|l|}{ 1. Are more frequent inspections required? } \\
\hline \multicolumn{4}{|l|}{ 2. Are existing maintenance/repair actions satisfactory? } \\
\hline 3. Is other maintenance/repair necessary? & & & $\begin{array}{l}\text { Please read field conclusions/recommendations } \\
\text { section. }\end{array}$ \\
\hline \multirow{2}{*}{\multicolumn{4}{|c|}{$\begin{array}{l}\text { 4. Field conclusions/recommendations: Overall site conditio } \\
\text { and radiological signage is good. Six use } \\
\text { a follow-up action. Only one RMA sign } \\
\text { that will have to be rehung. }\end{array}$}} \\
\hline & & & \\
\hline \multicolumn{4}{|l|}{ F. CERTIFICATION } \\
\hline \multicolumn{4}{|c|}{$\begin{array}{l}\text { I have conducted an inspection of CAS } 25-23-09 \text {, Contaminated Waste Dump \#1, in accordance with the procedures of the Post-Closure Plan as recorded on } \\
\text { this checklist, attached sheets, field notes, photographs, and photograph logs. }\end{array}$} \\
\hline Chief Inspector's Signature: /s/ Glenn Richardson & & Date: & 1,2 \\
\hline Printed Name: Glenen Kichardson & & Title: & Manager \\
\hline
\end{tabular}

Attachment: Maintenance records (check if attached) 


\section{CAU 165: AREA 25 AND 26 DRY WELL AND WASHDOWN AREAS}




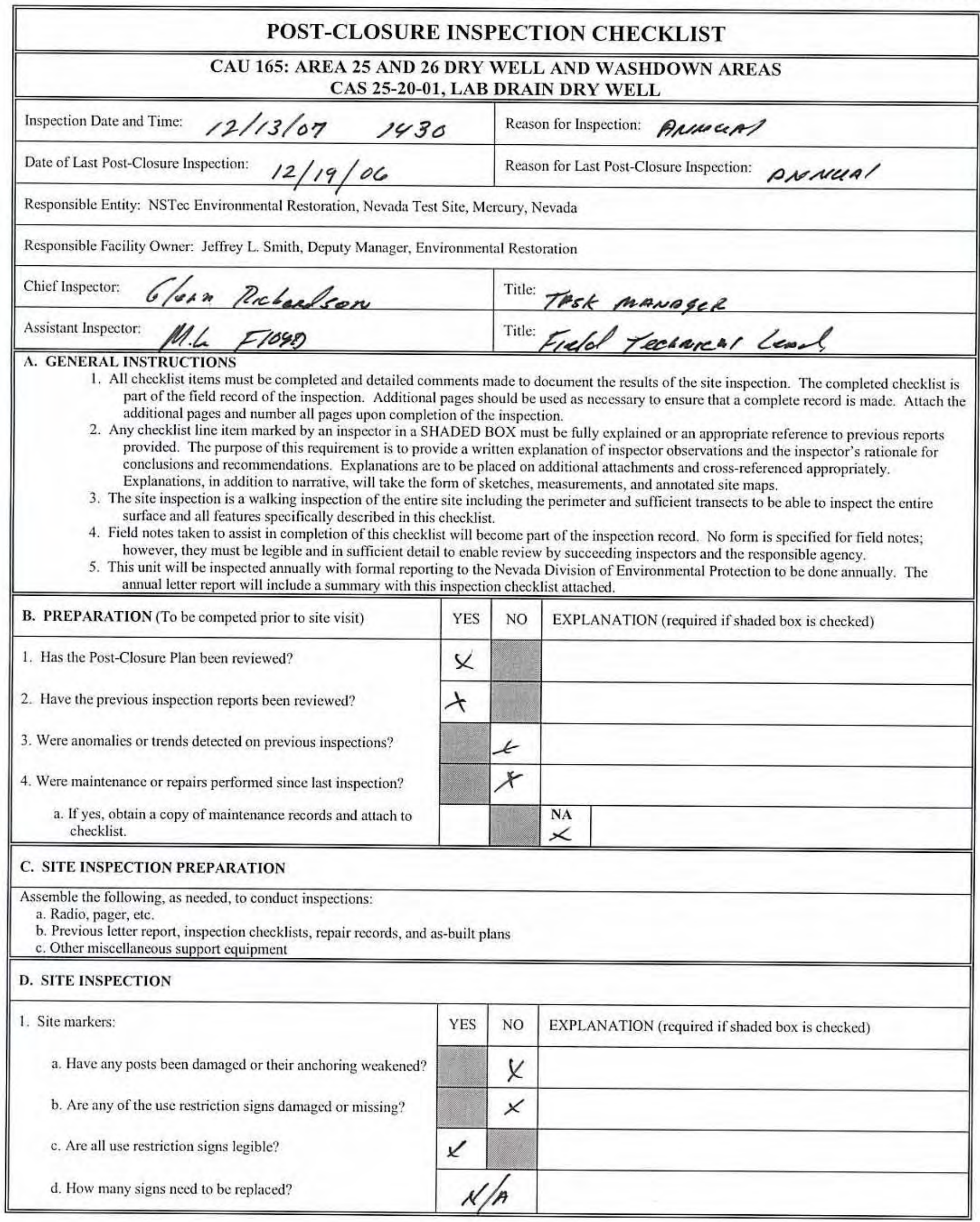




\begin{tabular}{|c|c|c|c|}
\hline \multicolumn{4}{|c|}{ POST-CLOSURE INSPECTION CHECKLIST } \\
\hline \multicolumn{4}{|c|}{$\begin{array}{l}\text { CAU 165: AREA } 25 \text { AND 26 DRY WELL AND WASHDOWN AREAS } \\
\text { CAS 25-20-01, LAB DRAIN DRY WELL } \\
\end{array}$} \\
\hline \multirow{2}{*}{$\begin{array}{l}\text { 2. Use-restricted area: } \\
\text { a. Is there evidence of human intrusion onto the site? }\end{array}$} & YES & NO & EXPLANATION (required if shaded box is checked) \\
\hline & & $x$ & \\
\hline \multirow{2}{*}{$\begin{array}{l}\text { 3. Photograph Documentation (optional): } \\
\text { a. Have photographs been taken of the site? }\end{array}$} & YES & NO & EXPLANATION \\
\hline & & & $N / A$ \\
\hline \multicolumn{4}{|l|}{ If yes, how many photos were taken? } \\
\hline If yes, has a photographic log been prepared? & & & Log number: \\
\hline E. FIELD CONCLUSIONS & YES & NO & EXPLANATION (required if shaded box is checked) \\
\hline \multicolumn{2}{|l|}{ 1. Are more frequent inspections required? } & $x$ & \\
\hline \multicolumn{4}{|l|}{ 2. Are existing maintenance/repair actions satisfactory? } \\
\hline 3. Is other maintenance/repair necessary? & & 火 & \\
\hline \multicolumn{4}{|c|}{ 4. Field conclusions/recommendations: Site was found fo Be in goed Conchtion } \\
\hline \multicolumn{4}{|l|}{ F. CERTIFICATION } \\
\hline \multicolumn{4}{|c|}{$\begin{array}{l}\text { I have conducted an inspection of CAS 25-20-01, Lab Drain Dry Well, in accordance with the procedures of the Post-Closure Plan as recorded on this } \\
\text { checklist, attached sheets, field notes, photographs, and photograph logs, }\end{array}$} \\
\hline \multicolumn{2}{|l|}{ Chief Inspector's Signature: /s/ Glenn Richardson } & Date: & $12 / 13 / 07$ \\
\hline Printed Name: flemn Recbandron & & & Tork Plop \\
\hline
\end{tabular}

Attachment: Maintenance records (check if attached) 
CAU 168: AREA 25 AND 26 CONTAMINATED MATERIALS AND WASTE 


\section{POST-CLOSURE INSPECTION CHECKLIST}

\section{CAU 168: AREA 25 AND 26 CONTAMINATED MATERIALS AND WASTE CAS 25-16-03, MX CONSTRUCTION LANDFILL}

\begin{tabular}{|c|c|}
\hline Inspection Date and Time: & Reason for Inspection: \\
\hline Date of Last Post-Closure Inspection: & Reason for Last Post-Closure Inspection: \\
\hline
\end{tabular}

Responsible Entity: NSTec Environmental Restoration, Nevada Test Site, Mercury, Nevada

Responsible Facility Owner: Jeffrey L. Smith, Deputy Manager, Environmental Restoration

Chief Inspector: Glenn Richaredron

Assistant Inspector:

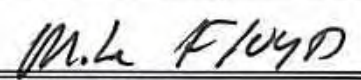

Title: THS/ MnNmGer

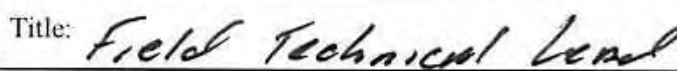

A. GENERAL INSTRUCTIONS

1. All checklist items must be completed and detailed comments made to document the results of the site inspection. The completed checklist is part of the field record of the inspection. Additional pages should be used as necessary to ensure that a complete record is made. Attach the additional pages and number all pages upon completion of the inspection.

2. Any checklist line item marked by an inspector in a SHADED BOX must be fully explained or an appropriate reference to previous reports provided. The purpose of this requirement is to provide a written explanation of inspector observations and the inspector's rationale for conclusions and recommendations. Explanations are to be placed on additional attachments and cross-referenced appropriately. Explanations, in addition to narrative, will take the form of sketches, measurements, and annotated site maps.

3. The site inspection is a walking inspection of the entire site including the perimeter and sufficient transects to be able to inspect the entire surface and all features specifically described in this checklist.

4. Field notes taken to assist in completion of this checklist will become part of the inspection record. No form is specified for field notes; however, they must be legible and in sufficient detail to enable review by succeeding inspectors and the responsible agency.

5. This unit will be inspected annually with formal reporting to the Nevada Division of Environmental Protection to be done annually. The annual letter report will include a summary with this inspection checklist attached.

B. PREPARATION (To be competed prior to site visit)

1. Has the Post-Closure Plan been reviewed?

2. Have the previous inspection reports been reviewed?

3. Were anomalies or trends detected on previous inspections?

4. Were maintenance or repairs performed since last inspection?

a. If yes, obtain a copy of maintenance records and attach to checklist.

b. If yes (on 4), has site repair resulted in a change from asbuilt conditions?

c. If yes (to $4 \mathrm{~b}$ ), are revised as-built plans available that reflect repair changes?

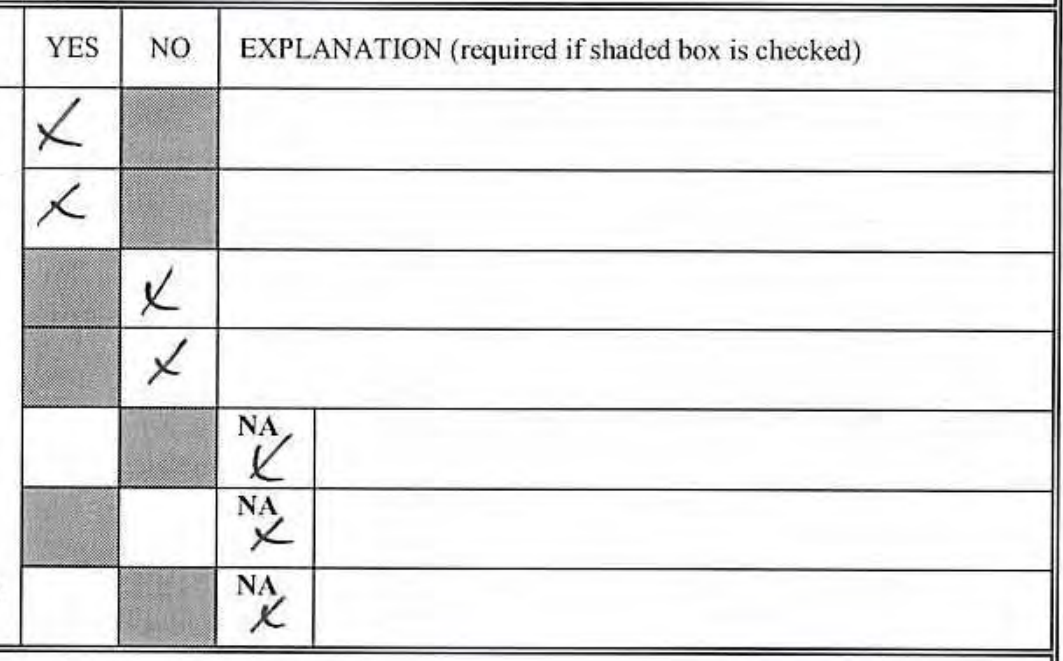

\section{SITE INSPECTION PREPARATION}

Assemble the following, as needed, to conduct inspections:

a. Radio, pager, etc.

b. Previous letter report, inspection checklists, repair records, and as-built plans

c. Other miscellaneous support equipment

\section{SITE INSPECTION}

1. Site markers:

a. Is there damage to the fence?

b. Have any posts been damaged or their anchoring weakened?

c. Are any of the of use restriction signs damaged or missing?

\begin{tabular}{|c|c|l||}
\hline YES & NO & EXPLANATION (required if shaded box is checked) \\
\hline & $\chi$ & \\
\hline & $X$ & \\
\hline & $\chi$ & \\
\hline
\end{tabular}




\section{POST-CLOSURE INSPECTION CHECKLIST}

\section{CAU 168: AREA 25 AND 26 CONTAMINATED MATERIALS AND WASTE CAS 25-16-03, MX CONSTRUCTION LANDFILL}

1. Site markers (continued):

d. Are all use restriction signs legible?

e. How many signs need to be replaced?

2. Use-restricted area:

a. Is there evidence of human intrusion onto the site?

3. Photograph Documentation (optional):

a. Have photographs been taken of the site?

If yes, how many photos were taken?

If yes, has a photographic $\log$ been prepared?

\begin{tabular}{|c|c|c|}
\hline YES & NO & EXPLANATION (required if shaded box is checked) \\
\hline$X$ & & \\
\hline
\end{tabular}

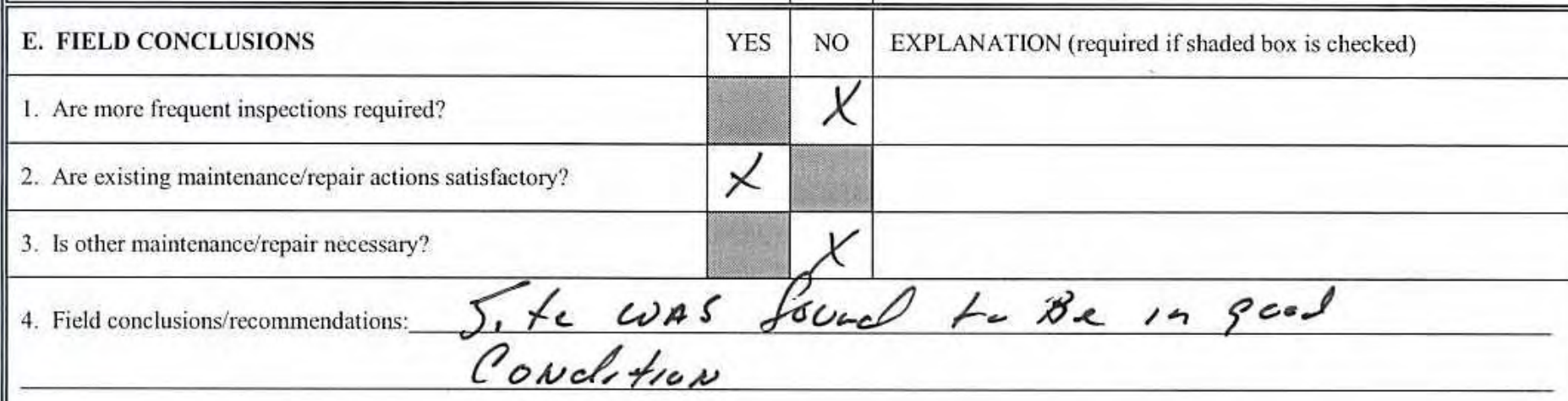

\section{F. CERTIFICATION}

I have conducted an inspection of CAS 25-16-03, MX Construction Landfill, in accordance with the procedures of the Post-Closure Plan as recorded on this checklist, attached sheets, field notes, photographs, and photograph logs.

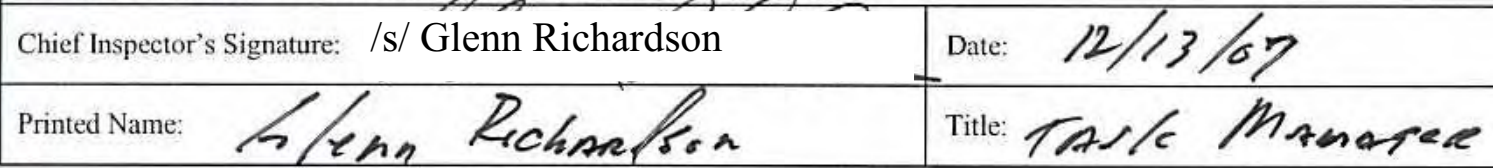

Attachments (check if attached):

$\square$ Maintenance records 


\section{POST-CLOSURE INSPECTION CHECKLIST}

\section{CAU 168: AREA 25 AND 26 CONTAMINATED MATERIALS AND WASTE CAS 25-23-02, RADIOACTIVE STORAGE RR CARS}

\begin{tabular}{||l|l|}
\hline \hline Inspection Date and Time: $12 / 13 / 07$ & Reason for Inspection: Annua $/ 15 \mathrm{PM}$ \\
\hline Date of Last Post-Closure Inspection: None & Reason for Last Post-Closure Inspection: \\
\hline
\end{tabular}

Responsible Entity: NSTec Environmental Restoration, Nevada Test Site, Mercury, Nevada

Responsible Facility Owner: Jeffrey L. Smith, Deputy Manager, Environmental Restoration

\begin{tabular}{|l|l||}
\hline Chief Inspector: Glenn Richardson & Title: Task Manager \\
\hline Assistant Inspector: Mike Floyd & Title: Field Technical Lead \\
\hline \hline A. Generam INSTRuctions
\end{tabular}

A. GENERAL INSTRUCTIONS

1. All checklist items must be completed and detailed comments made to document the results of the site inspection. The completed checklist is part of the ficld record of the inspection. Additional pages should be used as necessary to ensure that a complete record is made. Attach the additional pages and number all pages upon completion of the inspection.

2. Any checklist line item marked by an inspector in a SHADED BOX must be fully explained or an appropriate reference to previous reports provided. The purpose of this requirement is to provide a written explanation of inspector observations and the inspector's rationale for conclusions and recommendations. Explanations are to be placed on additional attachments and cross-referenced appropriately. Explanations, in addition to narrative, will take the form of sketches, measurements, and annotated site maps.

3. The site inspection is a walking inspection of the entire site including the perimeter and sufficient transects to be able to inspect the entire surface and all features specifically described in this checklist.

4. Field notes taken to assist in completion of this checklist will become part of the inspection record. No form is specified for field notes; however, they must be legible and in sufficient detail to enable review by succeeding inspectors and the responsible agency.

5. This unit will be inspected annually with formal reporting to the Nevada Division of Environmental Protection to be done annually. The annual letter report will include a summary with this inspection checklist attached.

$\begin{aligned} & \text { B. PREPARATION (To be competed prior to site visit) } \\ & \text { 1. Has the Post-Closure Plan been reviewed? }\end{aligned}$ 2. Have the previous inspection reports been reviewed?
$\begin{aligned} & \text { 3. Were anomalies or trends detected on previous inspections? } \\ & \text { 4. Were maintenance or repairs performed since last inspection? }\end{aligned}$

\section{SITE INSPECTION PREPARATION}

Assemble the following, as needed, to conduct inspections:

a. Radio, pager, etc.

b. Previous letter report, inspection checklists, repair records, and as-built plans

c. Other miscellaneous support equipment

\section{SITE INSPECTION}

1. Site markers:

a. Is there damage to the fence?

b. Have any posts been damaged or their anchoring weakened?

c. Are any of the 6 use restriction signs damaged or missing?

d. Are all use restriction signs legible?

e. How many signs need to be replaced?

\begin{tabular}{|l|l|l|}
\hline YES & NO & EXPLANATION (required if shaded box is checked) \\
\hline & & \\
\hline & & $\begin{array}{l}5 \text { signs are down and need to be rehung. } \\
1 \text { sign is loose and needs to be tightened. }\end{array}$ \\
\hline & $\begin{array}{l}5 \text { signs will be rehung and I sign will be } \\
\text { tightened. }\end{array}$ \\
\hline
\end{tabular}




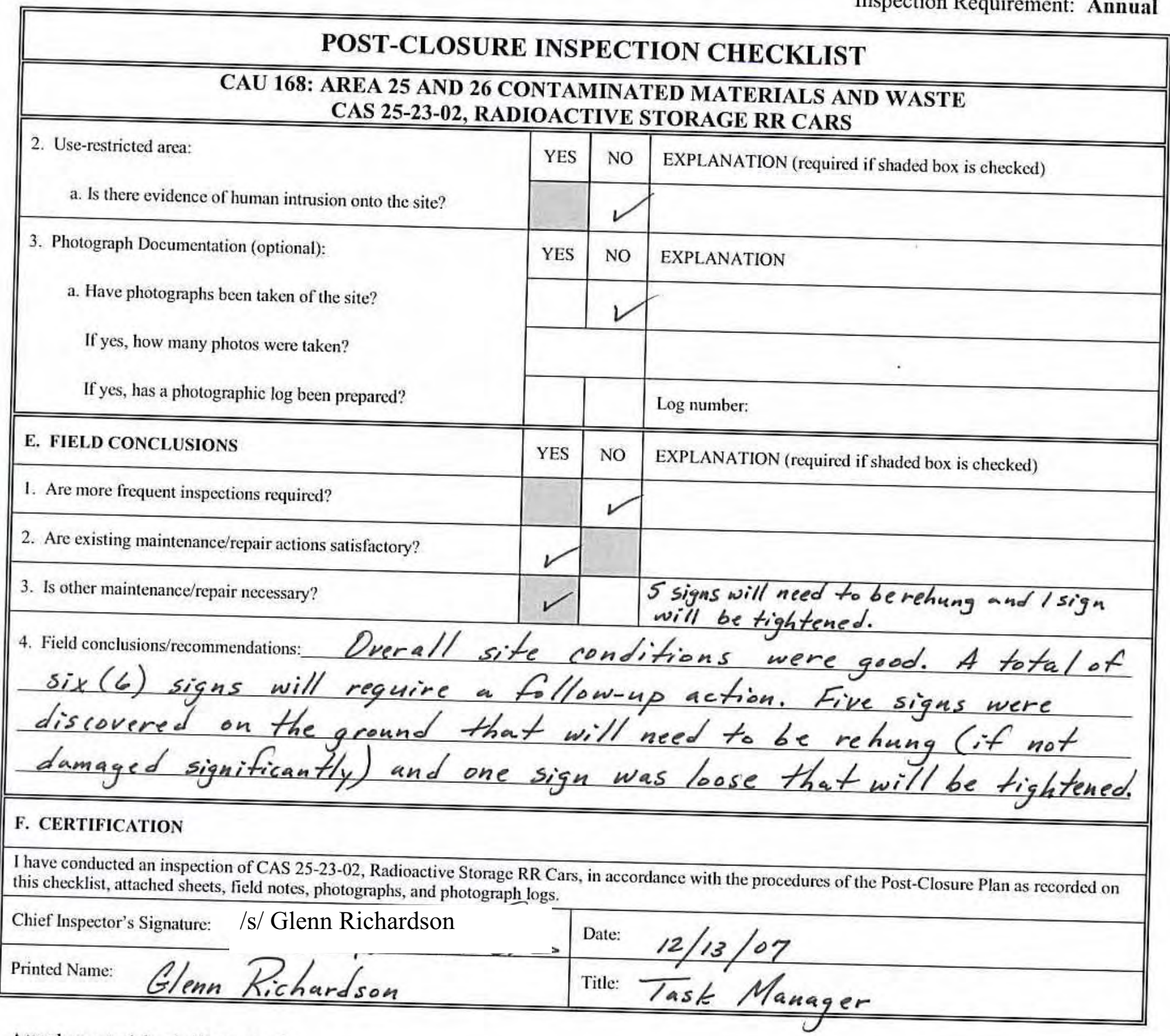

Attachments (check if attached):

$\square$ Maintenance records 


\section{POST-CLOSURE INSPECTION CHECKLIST}

\section{CAU 168: AREA 25 AND 26 CONTAMINATED MATERIALS AND WASTE CAS 25-99-16, USW G3}

\begin{tabular}{|c|c|c|}
\hline Inspection Date and Time: $\quad 12$ & $7 / 07 \quad 1030$ & Reason for Inspection: ANルレA \\
\hline Date of Last Post-Closure Inspection: & None & Reason for Last Post-Closure Inspection: \\
\hline
\end{tabular}

Responsible Entity: NSTec Environmental Restoration, Nevada Test Site, Mercury, Nevada

Responsible Facility Owner: Jeffrey L. Smith, Deputy Manager, Environmental Restoration

Chief inspector: S/lena Rechoptson

A. GENERAL INSTRUCTIONS

1. All checklist items must be completed and detailed comments made to document the results of the site inspection. The completed checklist is part of the field record of the inspection. Additional pages should be used as necessary to ensure that a complete record is made. Attach the additional pages and number all pages upon completion of the inspection.

2. Any checklist line item marked by an inspector in a SHADED BOX must be fully explained or an appropriate reference to previous reports provided. The purpose of this requirement is to provide a written explanation of inspector observations and the inspector's rationale for conclusions and recommendations. Explanations are to be placed on additional attachments and cross-referenced appropriately. Explanations, in addition to narrative, will take the form of sketches, measurements, and annotated site maps.

3. The site inspection is a walking inspection of the entire site including the perimeter and sufficient transects to be able to inspect the entire surface and all features specifically described in this checklist.

4. Field notes taken to assist in completion of this checklist will become part of the inspection record. No form is specified for field notes; however, they must be legible and in sufficient detail to enable review by succeeding inspectors and the responsible agency.

5. This unit will be inspected annually with formal reporting to the Nevada Division of Environmental Protection to be done annually. The annual letter report will include a summary with this inspection checklist attached.

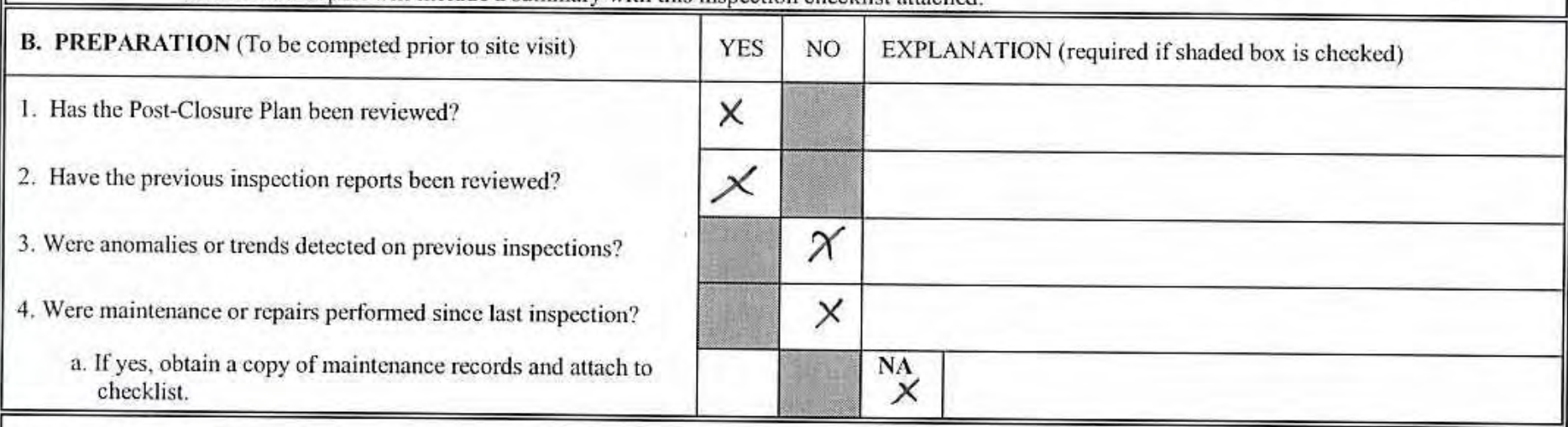

\section{SITE INSPECTION PREPARATION}

Assemble the following, as needed, to conduct inspections:

a. Radio, pager, etc.

b. Previous letter report, inspection checklists, repair records, and as-built plans

c. Other miscellaneous support equipment

\section{SITE INSPECTION}

1. Site markers:

a. Have any posts been damaged or their anchoring weakened?

b. Are any of the use restriction signs damaged or missing?

c. Are all use restriction signs legible?

d. How many signs need to be replaced?

\begin{tabular}{|l|l|l||}
\hline YES & NO & EXPLANATION (required if shaded box is checked) \\
\hline & E & \\
\hline & $X$ & \\
\hline$X$ & & \\
\hline
\end{tabular}




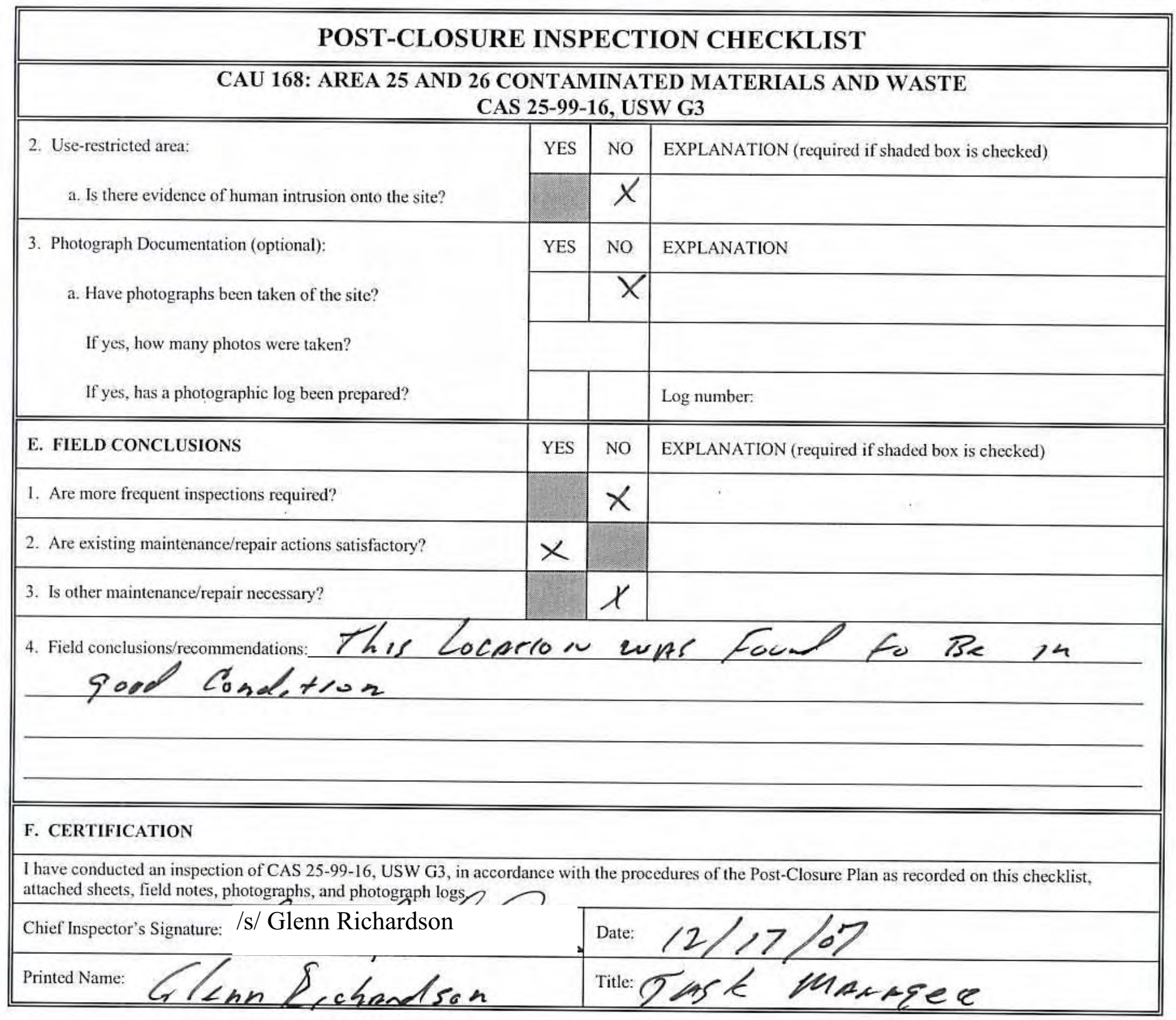

Attachments (check if attached):

$\square$ Maintenance records 
CAU 204: STORAGE BUNKERS 


\section{POST-CLOSURE INSPECTION CHECKLIST}

\section{CAU 204: STORAGE BUNKERS - CAS 01-34-01, UNDERGROUND INST. HOUSE BUNKER}

\begin{tabular}{||l|l|}
\hline \hline Inspection Date and Time: $1 / 16 / 08 \quad 12.50 \mathrm{PM}$ & Reason for Inspection: Annua/ \\
\hline Date of Last Post-Closure Inspection: $1 / 3 / 07$ & Reason for Last Post-Closure Inspection: Annua/ \\
\hline
\end{tabular}

Responsible Entity: NSTec Environmental Restoration, Nevada Test Site, Mercury, Nevada

Responsible Facility Owner: Jeffrey L. Smith, Deputy Manager, Environmental Restoration

\begin{tabular}{l|l} 
Chief Inspector: Glenn Kichardson & Title: Task Manager \\
\hline Assistant Inspector: Robert Green & Title: Field Technical Lead
\end{tabular}

A. GENERAL INSTRUCTIONS

1. All checklist items must be completed and detailed comments made to document the results of the site inspection. The completed checklist is part of the field record of the inspection. Additional pages should be used as necessary to ensure that a complete record is made. Attach the additional pages and number all pages upon completion of the inspection.

2. Any checklist line item marked by an inspector in a SHADED BOX must be fully explained or an appropriate reference to previous reports provided. The purpose of this requirement is to provide a written explanation of inspector observations and the inspector's rationale for conclusions and recommendations. Explanations are to be placed on additional attachments and cross-referenced appropriately. Explanations, in addition to narrative, will take the form of sketches, measurements, and annotated site maps.

3. The site inspection is a walking inspection of the entire site including the perimeter and sufficient transects to be able to inspect the entire surface and all features specifically described in this checklist.

4. Field notes taken to assist in completion of this checklist will become part of the inspection record. No form is specified for field notes; however, they must be legible and in sufficient detail to enable review by succeeding inspectors and the responsible agency.

5. This unit will be inspected annually with formal reporting to the Nevada Division of Environmental Protection to be done annually. The annual letter report will include a summary with this inspection checklist attached.

B. PREPARATION (To be competed prior to site visit)

1. Has the Post-Closure Plan been reviewed?

2. Have the previous inspection reports been reviewed?

3. Were anomalies or trends detected on previous inspections?

4. Were maintenance or repairs performed since last inspection?

\begin{tabular}{|l|l|l|}
\hline YES & NO & EXPLANATION (required if shaded box is checked) \\
\hline & & \\
\hline & & \\
\hline & & \\
\hline
\end{tabular}

\section{SITE INSPECTION PREPARATION}

Assemble the following, as needed, to conduct inspections:

a. Radio, pager, etc.

b. Previous letter report, inspection checklists, repair records, and as-built plans

c. Other miscellaneous support equipment

\section{SITE INSPECTION}

1. Site markers:

a. Have any posts been damaged or their anchoring weakened?

b. Are any of the use restriction signs damaged or missing?

c. Are all use restriction signs legible?

d. How many signs need to be replaced?

2. Use-restricted area:

a. Is there evidence of human intrusion onto the site?

\begin{tabular}{|l|l|l|}
\hline YES & NO & EXPLANATION (required if shaded box is checked) \\
\hline & & \\
\hline & & \\
\hline & 0 & \\
\hline & & \\
\hline YES & NO & EXPLANATION (required if shaded box is checked) \\
\hline & \multicolumn{1}{|c|}{} \\
\hline
\end{tabular}


POST-CLOSURE INSPECTION CHECKLIST

\section{CAU 204: STORAGE BUNKERS - CAS 01-34-01, UNDERGROUND INST. HOUSE BUNKER}

3. Photograph Documentation (optional):

a. Have photographs been taken of the site?

If yes, how many photos were taken?

If yes, has a photographic log been prepared?

\begin{tabular}{|c|c|c|}
\hline YES & NO & EXPLANATION \\
\hline & $\nu$ & \\
\hline & & Log number: \\
\hline YES & NO & EXPLANATION (required if shaded box is checked) \\
\hline
\end{tabular}

1. Are more frequent inspections required?

2. Are existing maintenance/repair actions satisfactory?

3 . Is other maintenance/repair necessary?

4. Field conclusions/recommendations: The use restriction sigus are legible, T-posts stable, and in good condition. There are no maintenance/repairs necessary at this site.

\section{F. CERTIFICATION}

I have conducted an inspection of CAS 01-34-01, Underground Inst. House Bunker, in accordance with the procedures of the Post-Closure Plan as recorded on this checklist, attached sheets, field notes, photographs, and photograph logs.

Chief Inspector's Signature: /s/ Glenn Richardson

Printed Name: Glenn Richardson

Date:

Title:

$1 / 16 / 108$

Task Manager 


\section{POST-CLOSURE INSPECTION CHECKLIST}

\section{CAU 204: STORAGE BUNKERS - CAS 02-34-01, INSTRUMENT BUNKER}

\begin{tabular}{||l|l|}
\hline \hline Inspection Date and Time: $1 / 16 / 08 \quad /: 14 \mathrm{PM}$ & Reason for Inspection: Annual \\
\hline Date of Last Post-Closure Inspection: $1 / 4 / 07$ & Reason for Last Post-Closure Inspection: Annua/
\end{tabular}

Responsible Entity: NSTec Environmental Restoration, Nevada Test Site, Mercury, Nevada

Responsible Facility Owner: Jeffrey L. Smith, Deputy Manager, Environmental Restoration

\begin{tabular}{|l|l}
\hline Chief Inspector: Geun Kichardson & Title: Task Manager \\
\hline Assistant Inspector: Robert Green & Title: Field Techuical Lead
\end{tabular}

A. GENERAL INSTRUCTIONS

1. All checklist items must be completed and detailed comments made to document the results of the site inspection. The completed checklist is part of the field record of the inspection. Additional pages should be used as necessary to ensure that a complete record is made. Attach the additional pages and number all pages upon completion of the inspection.

2. Any checklist line item marked by an inspector in a SHADED BOX must be fully explained or an appropriate reference to previous reports provided. The purpose of this requirement is to provide a written explanation of inspector observations and the inspector's rationale for conclusions and recommendations. Explanations are to be placed on additional attachments and cross-referenced appropriately. Explanations, in addition to narrative, will take the form of sketches, measurements, and annotated site maps.

3. The site inspection is a walking inspection of the entire site including the perimeter and sufficient transects to be able to inspect the entire surface and all features specifically described in this checklist.

4. Field notes taken to assist in completion of this checklist will become part of the inspection record. No form is specified for field notes: however, they must be legible and in sufficient detail to enable review by succeeding inspectors and the responsible agency.

5. This unit will be inspected annually with formal reporting to the Nevada Division of Environmental Protection to be done annually. The annual letter report will include a summary with this inspection checklist attached.

B. PREPARATION (To be competed prior to site visit)

1. Has the Post-Closure Plan been reviewed?

2. Have the previous inspection reports been reviewed?

3. Were anomalies or trends detected on previous inspections?

4. Were maintenance or repairs performed since last inspection?

\begin{tabular}{|l|l|l|}
\hline YES & NO & EXPLANATION (required if shaded box is checked) \\
\hline & & \\
\hline & & \\
\hline & & \\
\hline
\end{tabular}

\section{SITE INSPECTION PREPARATION}

Assemble the following, as needed, to conduct inspections:
a. Radio, pager, etc.
b. Previous letter report, inspection checklists, repair records, and as-built plans
c. Other miscellaneous support equipment

\section{SITE INSPECTION}

1. Site markers:

a. Have any posts been damaged or their anchoring weakened?

b. Are any of the use restriction signs damaged or missing?

c. Are all use restriction signs legible?

d. How many signs need to be replaced?

2. Use-restricted area:

a. Is there evidence of human intrusion onto the site? 


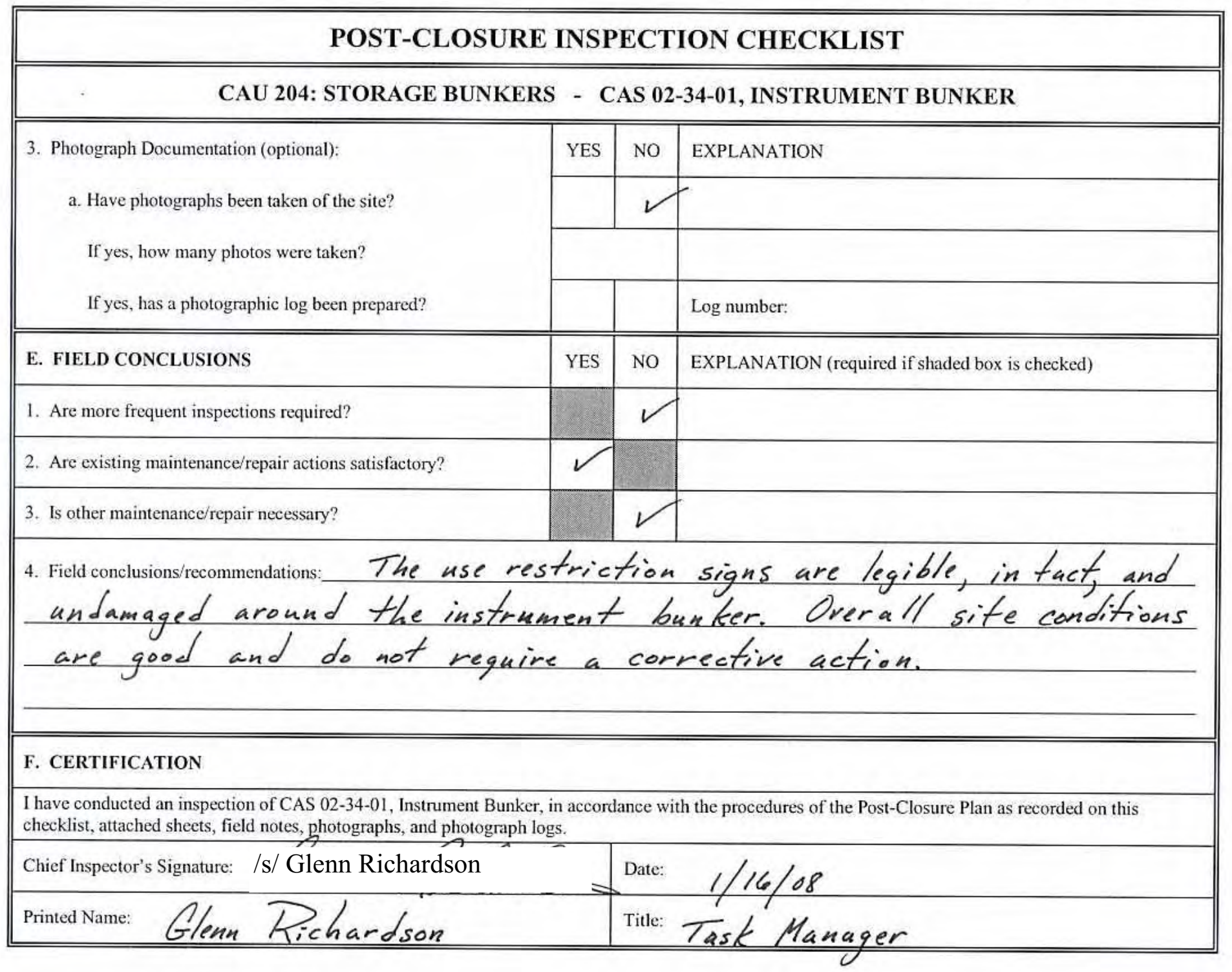




\section{POST-CLOSURE INSPECTION CHECKLIST}

\section{CAU 204: STORAGE BUNKERS - CAS 03-34-01, UNDERGROUND BUNKER}

\begin{tabular}{|l|l|}
\hline \hline Inspection Date and Time: $1 / 16 / 08 \quad 2: 07 \mathrm{PM}$ & Reason for Inspection: Annual \\
\hline Date of Last Post-Closure Inspection: $1 / 3 / 07$ & Reason for Last Post-Closure Inspection: An $\mathrm{nual}$ \\
\hline
\end{tabular}

Responsible Entity: NSTec Environmental Restoration, Nevada Test Site, Mercury, Nevada

Responsible Facility Owner: Jeffrey L. Smith, Deputy Manager, Environmental Restoration

\begin{tabular}{l|l} 
Chief Inspector: Glenn Richardson & Title: Task Manager \\
Assistant Inspector: Robert Green & Title: Field Techuical
\end{tabular}

A. GENERAL INSTRUCTIONS

1. All checklist items must be completed and detailed comments made to document the results of the site inspection. The completed checklist is part of the field record of the inspection. Additional pages should be used as necessary to ensure that a complete record is made. Attach the additional pages and number all pages upon completion of the inspection.

2. Any checklist line item marked by an inspector in a SHADED BOX must be fully explained or an appropriate reference to previous reports provided. The purpose of this requirement is to provide a written explanation of inspector observations and the inspector's rationale for conclusions and recommendations. Explanations are to be placed on additional attachments and cross-referenced appropriately. Explanations, in addition to narrative, will take the form of sketches, measurements, and annotated site maps.

3. The site inspection is a walking inspection of the entire site including the perimeter and sufficient transects to be able to inspect the entire surface and all features specifically described in this checklist.

4. Field notes taken to assist in completion of this checklist will become part of the inspection record. No form is specified for field notes; however, they must be legible and in sufficient detail to enable review by succeeding inspectors and the responsible agency.

5. This unit will be inspected annually with formal reporting to the Nevada Division of Environmental Protection to be done annually. The annual letter report will include a summary with this inspection checklist attached.

\section{B. PREPARATION (To be competed prior to site visit)}

1. Has the Post-Closure Plan been reviewed?

2. Have the previous inspection reports been reviewed?

3. Were anomalies or trends detected on previous inspections?

4. Were maintenance or repairs performed since last inspection?

\begin{tabular}{|l|l|l|}
\hline YES & NO & EXPLANATION (required if shaded box is checked) \\
\hline & & \\
\hline & & \\
\hline & & \\
\hline
\end{tabular}

\section{SITE INSPECTION PREPARATION}

Assemble the following, as needed, to conduct inspections:

a. Radio, pager, etc.

b. Previous letter report, inspection checklists, repair records, and as-built plans

c. Other miscellaneous support equipment

\section{SITE INSPECTION}

1. Site markers:

a. Have any posts been damaged or their anchoring weakened?

b. Are any of the use restriction signs damaged or missing?

c. Are all use restriction signs legible?

d. How many signs need to be replaced?

2. Use-restricted area:

a. Is there evidence of human intrusion onto the site?

\begin{tabular}{|c|l|l||}
\hline YES & NO & EXPLANATION (required if shaded box is checked) \\
\hline & & \\
\hline & & \\
\hline & & \\
\hline & & \\
\hline YES & NO & EXPLANATION (required if shaded box is checked) \\
\hline & N & \\
\hline
\end{tabular}




\section{POST-CLOSURE INSPECTION CHECKLIST}

\section{CAU 204: STORAGE BUNKERS - CAS 03-34-01, UNDERGROUND BUNKER}

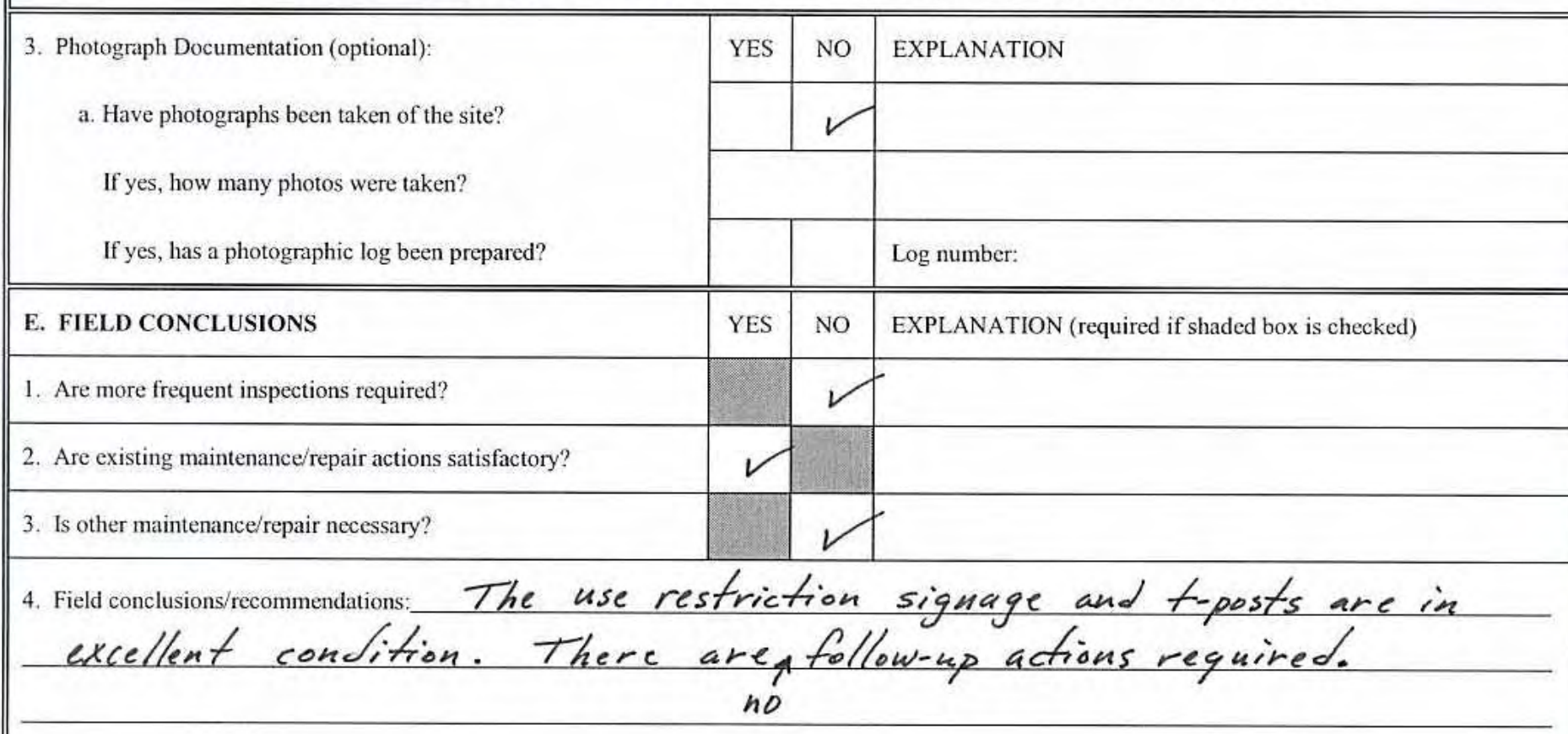

\section{F. CERTIFICATION}

I have conducted an inspection of CAS 03-34-01, Underground Bunker, in accordance with the procedures of the Post-Closure Plan as recorded on this checklist, attached sheets, field notes, photographs, and photograph logs.

Chief Inspector's Signature: /s/ Glenn Richardson

Printed Name: Glenn Fichardson

\begin{tabular}{l|l} 
Date: $1 / 16 / 08$ \\
Title: Task Manager
\end{tabular}


POST-CLOSURE INSPECTION CHECKLIST

CAU 204: STORAGE BUNKERS - CAS 05-18-02, CHEMICAL EXPLOSIVES STORAGE

\begin{tabular}{|c|c|}
\hline Inspection Date and Time: $12117 / 071600$ & Reason for Inspection: $A \sim \mu \sim A$ \\
\hline Date of Last Post-Closure Inspection: $\quad 1 / 4 / 07$ & Reason for Last Post-Closure Inspection: $A ル N レ ロ /$ \\
\hline
\end{tabular}

Responsible Entity: NSTec Environmental Restoration, Nevada Test Site, Mercury, Nevada

Responsible Facility Owner: Jeffrey L. Smith, Deputy Manager, Environmental Restoration

Chief Inspector: G/ene Rechrelsen

Assistant Inspector: $1 \mathrm{~h} . \mathrm{K}$ FlOG

A. GENERAL INSTRUCTIONS

1. All checklist items must be completed and detailed comments made to document the results of the site inspection. The completed checklist is part of the field record of the inspection. Additional pages should be used as necessary to ensure that a complete record is made. Attach the additional pages and number all pages upon completion of the inspection.

2. Any checklist line item marked by an inspector in a SHADED BOX must be fully explained or an appropriate reference to previous reports provided. The purpose of this requirement is to provide a written explanation of inspector observations and the inspector's rationale for conclusions and recommendations. Explanations are to be placed on additional attachments and cross-referenced appropriately.

Explanations, in addition to narrative, will take the form of sketches, measurements, and annotated site maps.

3. The site inspection is a walking inspection of the entire site including the perimeter and sufficient transects to be able to inspect the entire surface and all features specifically described in this checklist.

4. Field notes taken to assist in completion of this checklist will become part of the inspection record. No form is specified for field notes; however, they must be legible and in sufficient detail to enable review by succeeding inspectors and the responsible agency.

5. This unit will be inspected annually with formal reporting to the Nevada Division of Environmental Protection to be done annually. The annual letter report will include a summary with this inspection checklist attached.

\begin{tabular}{|c|c|c|c|}
\hline B. PREPARATION (To be competed prior to site visit) & YES & NO & EXPLANATION (required if shaded box is checked) \\
\hline 1. Has the Post-Closure Plan been reviewed? & & & \\
\hline 2. Have the previous inspection reports been reviewed? & & & \\
\hline 3. Were anomalies or trends detected on previous inspections? & & C & \\
\hline 4. Were maintenance or repairs performed since last inspection? & & & \\
\hline
\end{tabular}

\section{SITE INSPECTION PREPARATION}

Assemble the following, as needed, to conduct inspections:
a. Radio, pager, etc.
b. Previous letter report, inspection checklists, repair records, and as-built plans
c. Other miscellaneous support equipment

\section{SITE INSPECTION}

1. Site markers:

a. Is there damage to the fence?

b. Have any posts been damaged or their anchoring weakened?

c. Are any of the 13 use restriction signs damaged or missing?

d. Are all use restriction signs legible?

e. How many use restriction signs need to be replaced?

f. Are any of the RMA signs damaged or missing?

\begin{tabular}{|l|l|l||}
\hline YES & NO & EXPLANATION (required if shaded box is checked) \\
\hline & $X$ & \\
\hline & $X$ & \\
\hline & $X$ & \\
\hline$X$ & & \\
\hline \multicolumn{2}{|c||}{ X / $~$} & \\
\hline & $X$ & \\
\hline
\end{tabular}




\section{POST-CLOSURE INSPECTION CHECKLIST}

\section{CAU 204: STORAGE BUNKERS - CAS 05-18-02, CHEMICAL EXPLOSIVES STORAGE}

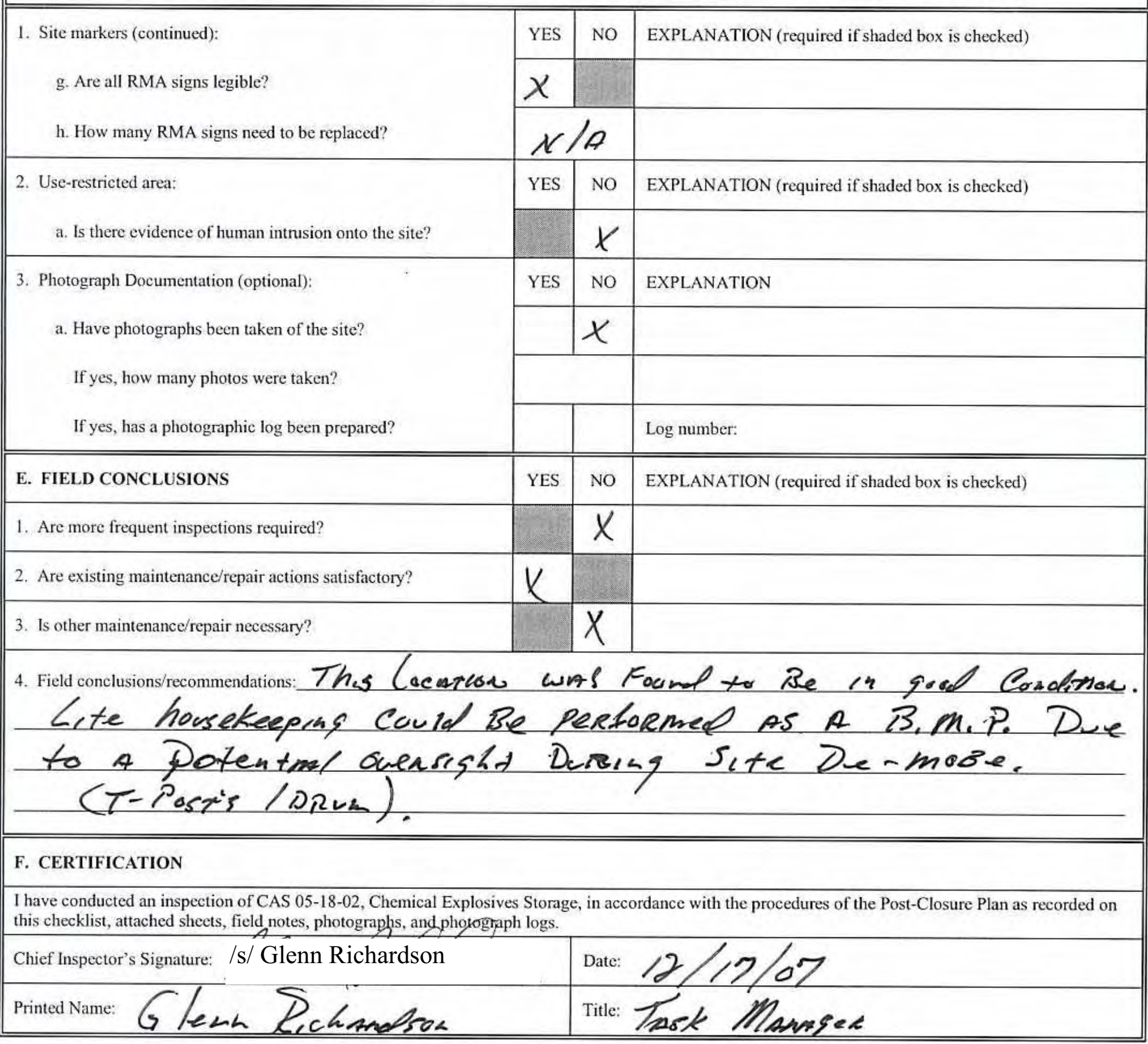




\section{POST-CLOSURE INSPECTION CHECKLIST}

\section{CAU 204: STORAGE BUNKERS - CAS 05-33-01, KAY BLOCKHOUSE}

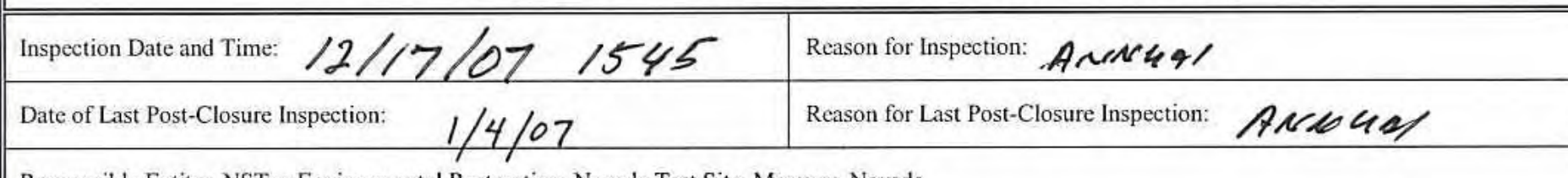

Responsible Entity: NSTec Environmental Restoration, Nevada Test Site, Mercury, Nevada

Responsible Facility Owner: Jeffrey L. Smith, Deputy Manager, Environmental Restoration

\section{Chief Inspector:

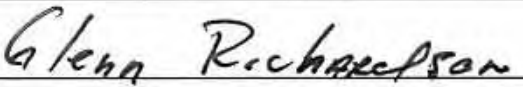

Assistant Inspector

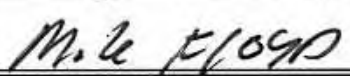

Title: Task MANASere Title: Fielol Tearnesel Lequel

A. GENERAL INSTRUCTIONS

1. All checklist items must be completed and detailed comments made to document the results of the site inspection. The completed checklist is part of the field record of the inspection. Additional pages should be used as necessary to ensure that a complete record is made. Attach the additional pages and number all pages upon completion of the inspection.

2. Any checklist line item marked by an inspector in a SHADED BOX must be fully explained or an appropriate reference to previous reports provided. The purpose of this requirement is to provide a written explanation of inspector observations and the inspector's rationale for conclusions and recommendations. Explanations are to be placed on additional attachments and cross-referenced appropriately. Explanations, in addition to narrative, will take the form of sketches, measurements, and annotated site maps.

3. The site inspection is a walking inspection of the entire site including the perimeter and sufficient transects to be able to inspect the entire surface and all features specifically described in this checklist.

4. Field notes taken to assist in completion of this checklist will become part of the inspection record. No form is specified for field notes; however, they must be legible and in sufficient detail to enable review by succeeding inspectors and the responsible agency.

5. This unit will be inspected annually with formal reporting to the Nevada Division of Environmental Protection to be done annually. The annual letter report will include a summary with this inspection checklist attached.

B. PREPARATION (To be competed prior to site visit)

1. Has the Post-Closure Plan been reviewed?

2. Have the previous inspection reports been reviewed?

3. Were anomalies or trends detected on previous inspections?

4. Were maintenance or repairs performed since last inspection?

\begin{tabular}{|l|l|l||}
\hline YES & NO & EXPLANATION (required if shaded box is checked) \\
\hline$X$ & & \\
\hline & & \\
\hline & $X$ & \\
\hline & $X$ & \\
\hline
\end{tabular}

\section{SITE INSPECTION PREPARATION}

Assemble the following, as needed, to conduct inspections:

a. Radio, pager, etc.

b. Previous letter report, inspection checklists, repair records, and as-built plans

c. Other miscellaneous support equipment

\section{SITE INSPECTION}

1. Site markers:

a. Is there damage to the fence?

b. Have any posts been damaged or their anchoring weakened?

c. Are any of the 11 use restriction signs damaged or missing?

d. Are all use restriction signs legible?

e. How many use restriction signs need to be replaced?

f. Are any of the RMA signs damaged or missing?

\begin{tabular}{|l|l|l||}
\hline YES & NO & EXPLANATION (required if shaded box is checked) \\
\hline & $\chi$ & \\
\hline & $\chi$ & \\
\hline & $\chi$ & \\
\hline$\chi$ & & \\
\hline \multicolumn{2}{|c||}{} & \\
\hline
\end{tabular}




\section{POST-CLOSURE INSPECTION CHECKLIST}

CAU 204: STORAGE BUNKERS - CAS 05-33-01, KAY BLOCKHOUSE

1. Site markers (continued):

g. Are all RMA signs legible?

h. How many RMA signs need to be replaced?

2. Use-restricted area:

a. Is there evidence of human intrusion onto the site?

3. Photograph Documentation (optional):

a. Have photographs been taken of the site?

If yes, how many photos were taken?

If yes, has a photographic $\log$ been prepared?

\begin{tabular}{|l|l|l|l}
\hline E. FIELD CONCLUSIONS & YES & NO & EXPLANATION (required if shaded box is checked) \\
\hline 1. Are more frequent inspections required? & & C & \\
\hline 2. Are existing maintenance/repair actions satisfactory? & & \\
\hline 3. Is other maintenance/repair necessary? & 4. Field conclusions/recommendations:
\end{tabular}

\section{F. CERTIFICATION}

I have conducted an inspection of CAS 05-33-01, Kay Blockhouse, in accordance with the procedures of the Post-Closure Plan as recorded on this checklist, attached sheets, field notes, photographs, and photograph logs.

Chief Inspector's Signature: /s/ Glenn Richardson




\section{CAU 214: BUNKERS AND STORAGE AREAS}


POST-CLOSURE INSPECTION CHECKLIST

CAU 214: BUNKERS AND STORAGE AREAS - CAS 25-23-01, CONTAMINATED MATERIALS

CAS 25-23-19, RADIOACTIVE MATERIALS STORAGE

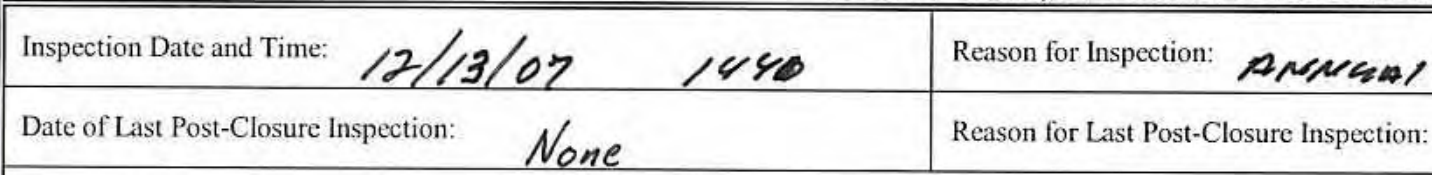

Responsible Entity: NSTec Environmental Restoration, Nevada Test Site, Mercury, Nevada

Responsible Facility Owner: Jeffrey L. Smith, Deputy Manager, Environmental Restoration

\begin{tabular}{|c|c|}
\hline Chief Inspector: Clewn Richonedrox & Title: Task Mannger \\
\hline Assistant Inspector: M.L Fl○YD & Title: Fielol Techn. \\
\hline
\end{tabular}

A. GENERAL INSTRUCTIONS

1. All checklist items must be completed and detailed comments made to document the results of the site inspection. The completed checklist is part of the field record of the inspection. Additional pages should be used as necessary to ensure that a complete record is made. Attach the additional pages and number all pages upon completion of the inspection.

2. Any checklist line item marked by an inspector in a SHADED BOX must be fully explained or an appropriate reference to previous reports provided. The purpose of this requirement is to provide a written explanation of inspector observations and the inspector's rationale for conclusions and recommendations. Explanations are to be placed on additional attachments and cross-referenced appropriately. Explanations, in addition to narrative, will take the form of sketches, measurements, and annotated site maps.

3. The site inspection is a walking inspection of the entire site including the perimeter and sufficient transects to be able to inspect the entire surface and all features specifically described in this checklist.

4. Field notes taken to assist in completion of this checklist will become part of the inspection record. No form is specified for field notes; however, they must be legible and in sufficient detail to enable review by succeding inspectors and the responsible agency.

5. This unit will be inspected annually with formal reporting to the Nevada Division of Environmental Protection to be done annually. The annual letter report will include a summary with this inspection checklist attached.

B. PREPARATION (To be competed prior to site visit)

1. Has the Post-Closure Plan been reviewed?

2. Have the previous inspection reports been reviewed?

3. Were anomalies or trends detected on previous inspections?

4. Were maintenance or repairs performed since last inspection?

a. If yes, obtain a copy of maintenance records and attach to checklist.

\begin{tabular}{|c|c|c||}
\hline YES & NO & \multicolumn{2}{|l|}{ EXPLANATION (required if shaded box is checked) } \\
\hline$\chi$ & & \\
\hline & & \\
\hline & $\chi$ & \\
\hline & & \multicolumn{2}{|l|}{} \\
\hline
\end{tabular}

\section{SITE INSPECTION PREPARATION}

Assemble the following, as needed, to conduct inspections:

a. Radio, pager, etc.

b. Previous letter report, inspection checklists, repair records, and as-built plans

c. Other miscellaneous support equipment

\section{SITE INSPECTION}

1. Site markers:

a. Is there damage to the fence?

b. Are any of the use restriction signs damaged or missing?

c. Are all use restriction signs legible?

d. How many use restriction signs need to be replaced?

e. Have any posts been damaged or their anchoring weakened?

\begin{tabular}{|l|l|l||}
\hline YES & NO & EXPLANATION (required if shaded box is checked) \\
\hline & $X$ & \\
\hline & $X$ & \\
\hline$X$ & & \\
\hline \multicolumn{1}{|l|}{} & & \\
\hline & $X$ & \\
\hline
\end{tabular}




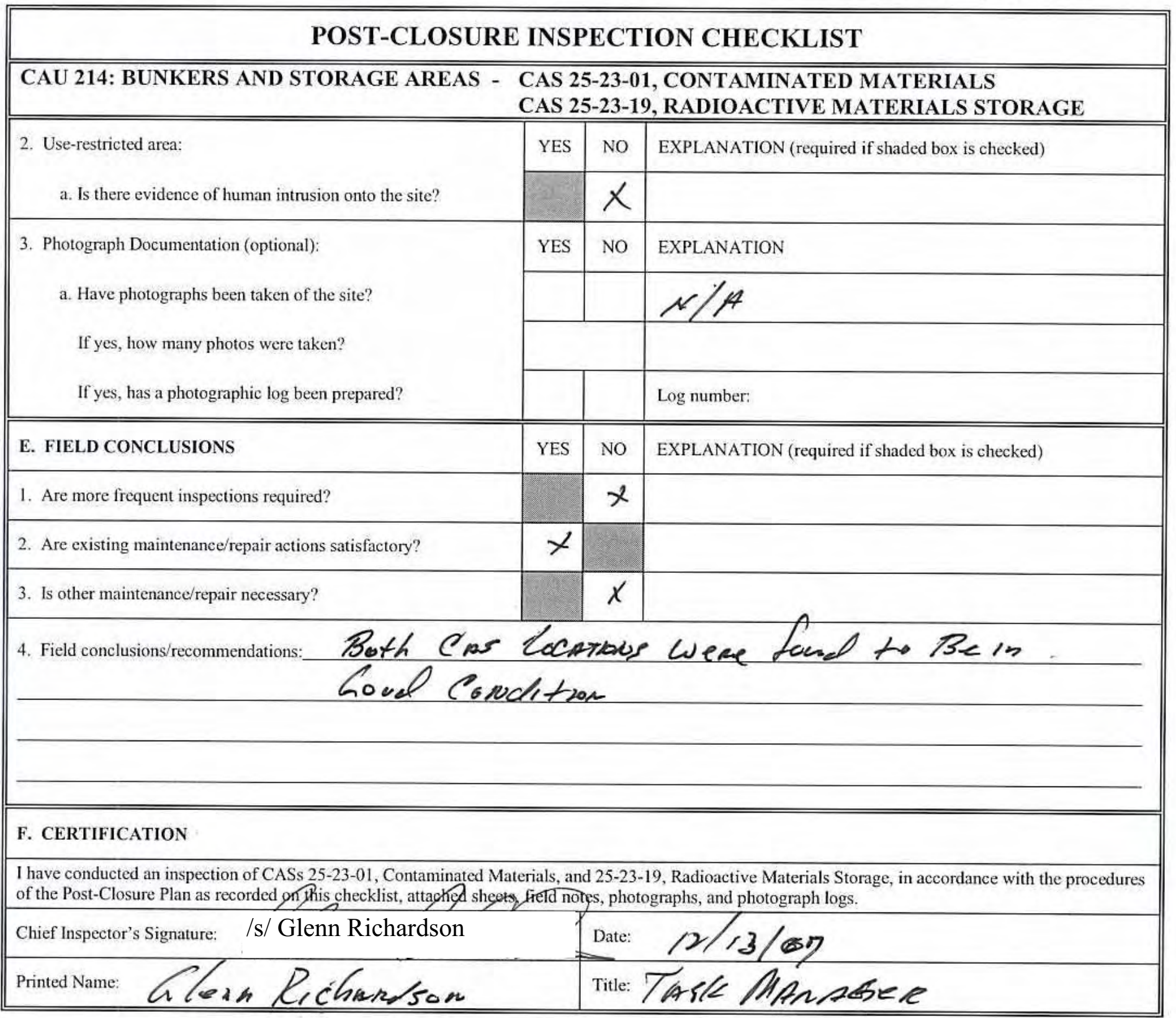

Attachments (check if attached):

$\square$ Maintenance records

ㅁ. Field Notes 
TITLE

Work continued from Page 22
PROJECT NO.

BOOK NO.

CAS 25-27-03 Discovered that CAC 528 has multiple use restriction areasmithin and near Test Cell $C$ complex. Three largesigns need to be rehung and/or reinstalled. Leaving CAU 528 sites at 11:07AM.

$5 \quad 644529$

CAS 25-23-17 Arrived $C$ the site of 11: 11 AM. The wire fencing is strung tightly and in good condition. I uR sign needs to be rehung. The remaining $U R$ signs ane not damaged and in good condition. Leaving the site at 11:15 AM. Heading to Mercury for

10

CAM 148

CAS 25-16-03 Arrived the site at 2:08 PM. The wire rope fencing and UR signage are in good condition. The landfill cover shows no sign of erosion. Rip rap along the south and west sections of the land fill are 15 in great condition. There are no followup actions required at this site. Leaving CALC 168 MX Landfill af 2:19 PM.

CAM 165

CAS 25-20-01 Arrived e the site at 2:30 PM. The T-posts and signage are 20 in excellent condition. This site has no issues or concerns. Leaving the site at $2: 34 \mathrm{PM}$.

CAM 214

CAS 25-23-19/CAS 25-23-01 Arrived \& the sites at 2:360M. The fencing 25 and $U R$ signage are in good condition. There is no sign of intrusion in use-restricted areas. There are no actions warranted at these sites.

Leaving the two sites at 2:40 PM.

www.scientificbindery88yrs.com

SIGNATURE /s/ Glenn Richardson

DISCLOSED TO AND UNDERSTOOD BY
Work continued to Page 24

DATE

$12 / 13 / 17$ 
CAU 254: AREA 25 R-MAD DECONTAMINATION FACILITY 


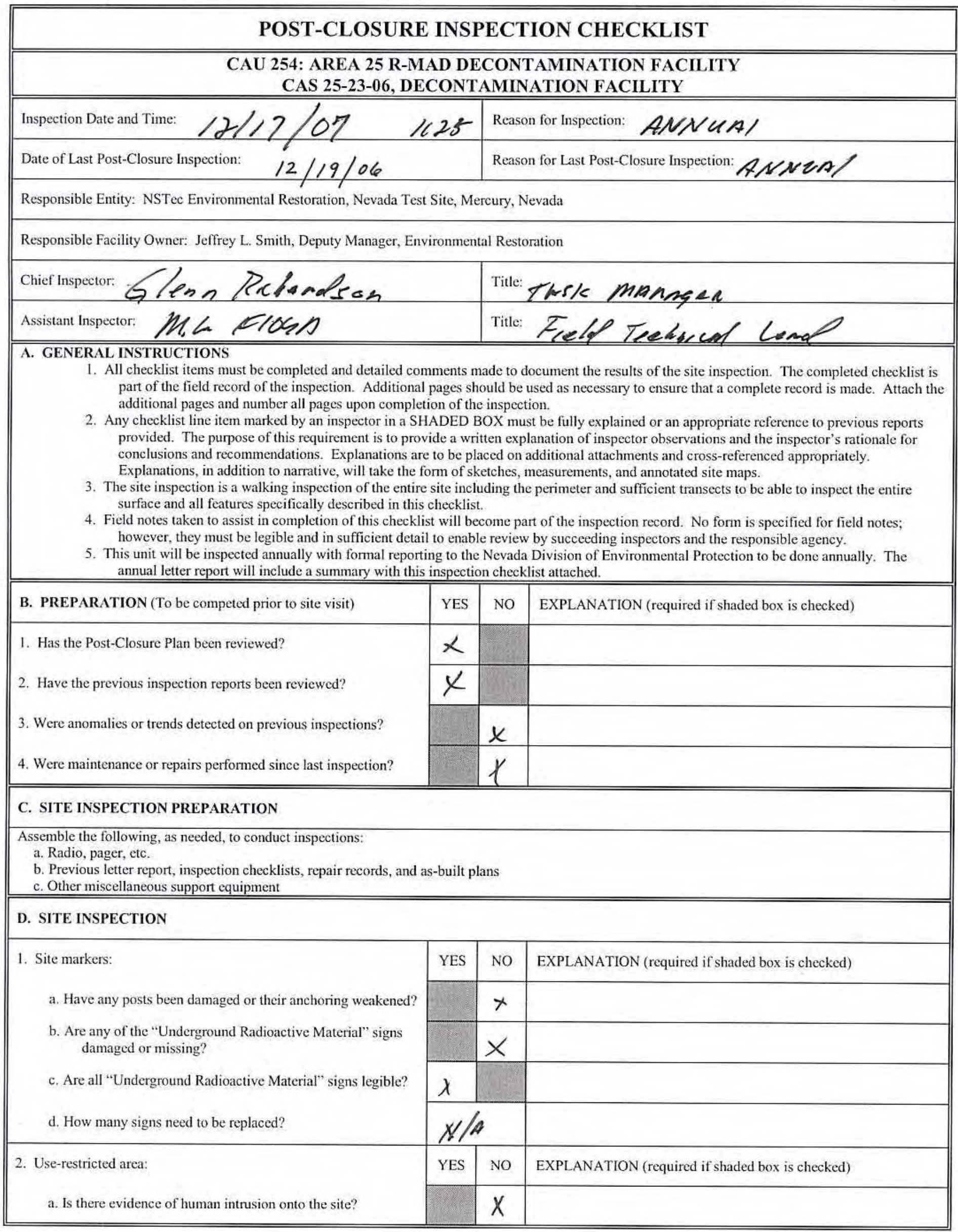




\begin{tabular}{|c|c|c|c|}
\hline \multicolumn{4}{|c|}{ POST-CLOSURE INSPECTION CHECKLIST } \\
\hline \multicolumn{4}{|c|}{$\begin{array}{l}\text { CAU 254: AREA 25 R-MAD DECONTAMINATION FACILITY } \\
\text { CAS 25-23-06, DECONTAMINATION FACILITY } \\
\end{array}$} \\
\hline \multirow{4}{*}{$\begin{array}{l}\text { 3. Photograph Documentation (optional): } \\
\text { a. Have photographs been taken of the site? } \\
\text { If yes, how many photos were taken? } \\
\text { If yes, has a photographic log been prepared? }\end{array}$} & YES & NO & EXPLANATION \\
\hline & \multirow{2}{*}{\multicolumn{2}{|c|}{$X$}} & \\
\hline & & & \\
\hline & & & Log number: \\
\hline E. FIELD CONCLUSIONS & YES & NO & EXPLANATION (required if shaded box is checked) \\
\hline \multicolumn{4}{|l|}{ 1. Are more frequent inspections required? } \\
\hline 2. Are existing maintenance/repair actions satisfactory? & $X$ & & \\
\hline 3. Is other maintenance/repair necessary? & & $x$ & \\
\hline \multicolumn{4}{|c|}{ 4. Field conclusions/recommendations: Thie Cocates war Foand to Be 13 g wall } \\
\hline \multicolumn{4}{|l|}{ F. CERTIFICATION } \\
\hline \multicolumn{4}{|c|}{$\begin{array}{l}\text { I have conducted an inspection of CAS 25-23-06, Decontamination Facility, in accordance with the procedures of the Post-Closure Plan as recorded on this } \\
\text { checklist, attached sheets, field notes, photographs, and photograpptags. }\end{array}$} \\
\hline \multicolumn{2}{|c|}{ Chief Inspector's Signature: /s/ Glenn Richardson } & \multicolumn{2}{|c|}{ Date: $12 / 11 / 67$} \\
\hline Printed Name: Tlenn Richaned & & Title: & Turle Monsper \\
\hline
\end{tabular}


CAU 261: AREA 25 TEST CELL A LEACHFIELD SYSTEM 


\section{POST-CLOSURE INSPECTION CHECKLIST}

\section{CAU 261: AREA 25 TEST CELL A LEACHFIELD SYSTEM CAS 25-05-01, LEACHFIELD}

\begin{tabular}{|c|c|}
\hline Inspection Date and Time: $12 / 13 / 07$ & Reason for Inspection: ANNUA/ \\
\hline Date of Last Post-Closure Inspection: $\quad 12 / 19 / 06$ & Reason for Last Post-Closure Inspection: ANNC P/ \\
\hline
\end{tabular}

Responsible Entity: NSTec Environmental Restoration, Nevada Test Site, Mercury, Nevada

Responsible Facility Owner: Jeffrey L. Smith, Deputy Manager, Environmental Restoration

\begin{tabular}{|c|c|}
\hline Chief Inspector: Clenn $\mathbb{R}_{\text {ichandsen }}$ & Title: ThJk ManAGer \\
\hline Assistant Inspector: & Title: \\
\hline
\end{tabular}

A. GENERAL INSTRUCTIONS

1. All checklist items must be completed and detailed comments made to document the results of the site inspection. The completed checklist is part of the field record of the inspection. Additional pages should be used as necessary to ensure that a complete record is made. Attach the additional pages and number all pages upon completion of the inspection.

2. Any checklist line item marked by an inspector in a SHADED BOX must be fully explained or an appropriate reference to previous reports provided. The purpose of this requirement is to provide a written explanation of inspector observations and the inspector's rationale for conclusions and recommendations. Explanations are to be placed on additional attachments and cross-referenced appropriately. Explanations, in addition to narrative, will take the form of sketches, measurements, and annotated site maps.

3. The site inspection is a walking inspection of the entire site including the perimeter and sufficient transects to be able to inspect the entire surface and all features specifically described in this checklist.

4. Field notes taken to assist in completion of this checklist will become part of the inspection record. No form is specified for field notes; however, they must be legible and in sufficient detail to enable review by succeeding inspectors and the responsible agency.

5. This unit will be inspected annually with formal reporting to the Nevada Division of Environmental Protection to be done annually. The annual letter report will include a summary with this inspection checklist attached.

\begin{tabular}{|c|c|c|c|}
\hline B. PREPARATION (To be competed prior to site visit) & YES & NO & EXPLANATION (required if shaded box is checked) \\
\hline \multicolumn{4}{|l|}{ 1. Has the Post-Closure Plan been reviewed? } \\
\hline \multicolumn{4}{|l|}{ 2. Have the previous inspection reports been reviewed? } \\
\hline \multicolumn{4}{|l|}{ 3. Were anomalies or trends detected on previous inspections? } \\
\hline \multirow{2}{*}{$\begin{array}{l}\text { 4. Were maintenance or repairs performed since last inspection? } \\
\text { a. If yes, obtain a copy of maintenance records and attach to } \\
\text { checklist. }\end{array}$} & & & Mainfenance was completed in Jan. 2007. \\
\hline & & & \begin{tabular}{c|l} 
NA & Degree of maintenance was very mindr. E-moil \\
$X$ & verification of maintenance completion is \\
\end{tabular} \\
\hline
\end{tabular}

Assemble the following, as needed, to conduct inspections:

a. Radio, pager, etc.

b. Previous letter report, inspection checklists, repair records, and as-built plans

c. Other miscellaneous support equipment

\section{SITE INSPECTION}

1. Site markers:

a. Is there damage to the fence?

b. Have any posts been damaged or their anchoring weakened?

c. Are any of the use restriction signs damaged or missing?

d. Are all use restriction signs legible?

e. How many signs need to be replaced?

\begin{tabular}{|c|c|l||}
\hline YES & NO & EXPLANATION (required if shaded box is checked) \\
\hline & $\swarrow$ & \\
\hline & $\swarrow$ & \\
\hline & $\swarrow$ & \\
\hline$\ell$ & & \\
\hline \multicolumn{2}{|c||}{$N / A$} & \\
\hline
\end{tabular}




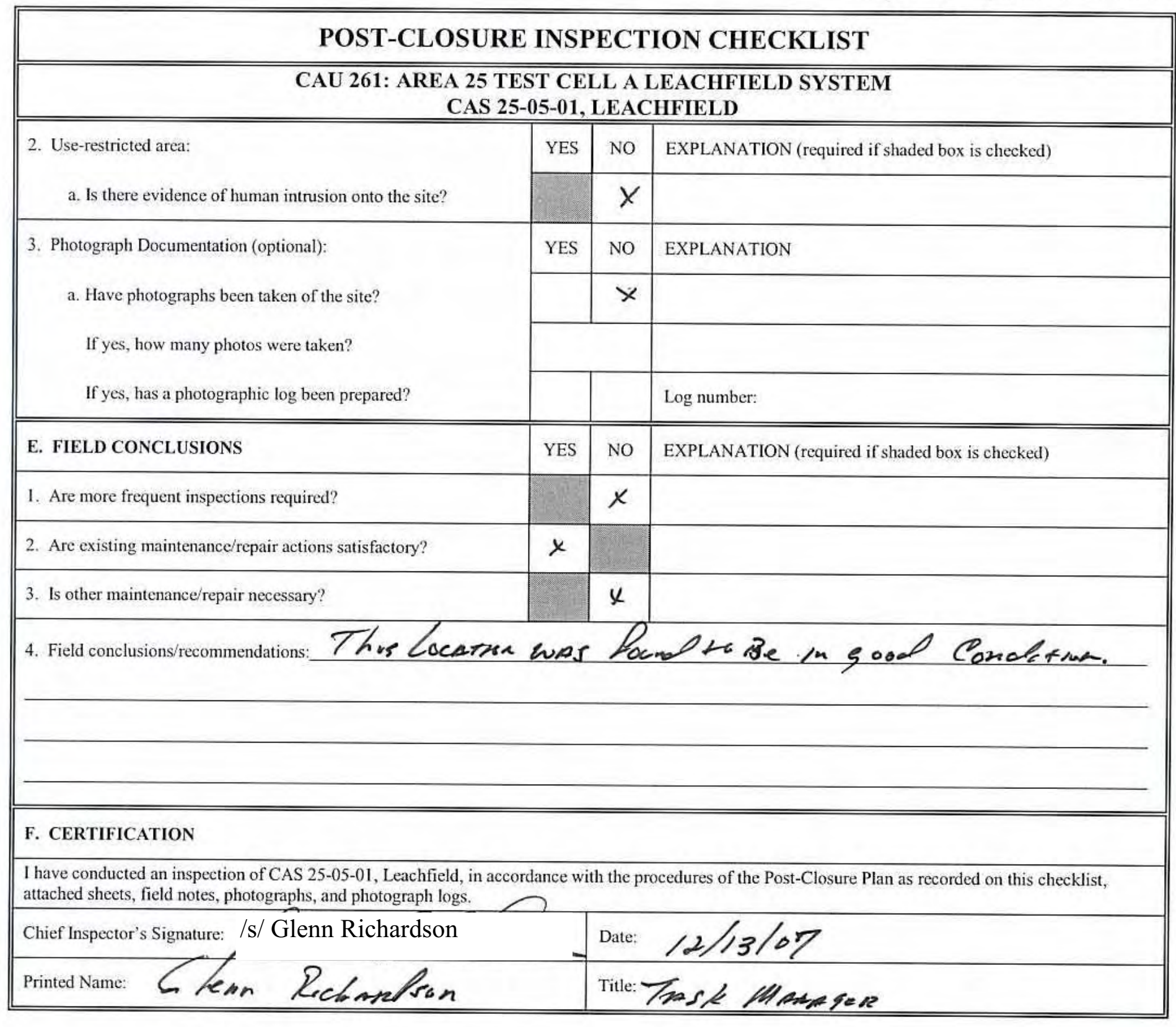

Attachments (check if attached):

$\square$ Maintenance records 
CAU 262: AREA 25 SEPTIC SYSTEMS AND UDP 


\section{POST-CLOSURE INSPECTION CHECKLIST}

\section{CAU 262: AREA 25 SEPTIC SYSTEMS AND UDP}

CAS 25-02-06, UNDERGROUND STORAGE TANK \& CAS 25-05-06, LEACHFIELD

\begin{tabular}{||l|l|}
\hline \hline Inspection Date and Time: $12 / 3 / 07$ & Reason for Inspection: AN/OU/ \\
\hline Date of Last Post-Closure Inspection: $12 / 19 / 06$ & Reason for Last Post-Closure Inspection: PNNOA/ \\
\hline
\end{tabular}

Responsible Entity: NSTec Environmental Restoration, Nevada Test Site, Mercury, Nevada

Responsible Facility Owner: Jeffrey L. Smith, Deputy Manager, Environmental Restoration

\begin{tabular}{|c|c|}
\hline chief Inspector: Glenn Ruchuralson & Title: Task Mnnosen \\
\hline Assistant Inspector: M.Le F/O4n & Title: Field Techin, \\
\hline
\end{tabular}

A. GENERAL INSTRUCTIONS

1. All checklist items must be completed and detailed comments made to document the results of the site inspection. The completed checklist is part of the field record of the inspection. Additional pages should be used as necessary to ensure that a complete record is made. Attach the additional pages and number all pages upon completion of the inspection.

2. Any checklist line item marked by an inspector in a SHADED BOX must be fully explained or an appropriate reference to previous reports provided. The purpose of this requirement is to provide a written explanation of inspector observations and the inspector's rationale for conclusions and recommendations. Explanations are to be placed on additional attachments and cross-referenced appropriately. Explanations, in addition to narrative, will take the form of sketches, measurements, and annotated site maps.

3. The site inspection is a walking inspection of the entire site including the perimeter and sufficient transects to be able to inspect the entire surface and all features specifically described in this checklist.

4. Field notes taken to assist in completion of this checklist will become part of the inspection record. No form is specified for field notes; however, they must be legible and in sufficient detail to enable review by succeeding inspectors and the responsible agency.

5. This unit will be inspected annually with formal reporting to the Nevada Division of Environmental Protection to be done annually. The annual letter report will include a summary with this inspection checklist attached.

\begin{tabular}{|l|l|l|l|}
\hline B. PREPARATION (To be competed prior to site visit) & YES & NO & EXPLANATION (required if shaded box is checked) \\
\hline 1. Has the Post-Closure Plan been reviewed? & 2. Have the previous inspection reports been reviewed? & & \\
3. Were anomalies or trends detected on previous inspections? & &
\end{tabular}

\section{SITE INSPECTION PREPARATION}

Assemble the following, as needed, to conduct inspections:

a. Radio, pager, etc.

b. Previous letter report, inspection checklists, repair records, and as-built plans

c. Other miscellaneous support equipment

\section{SITE INSPECTION}

1. Site markers (CAS 25-02-06):

a. Have any posts been damaged or their anchoring weakened?

b. Is either of the 2 use restriction signs damaged or missing?

c. Are all use restriction signs legible?

d. How many signs need to be replaced?

2. Use-restricted area (CAS 25-02-06):

a. Is there evidence of human intrusion onto the site?

\begin{tabular}{|c|c|c|}
\hline YES & NO & EXPLANATION (required if shaded box is checked) \\
\hline & $\chi$ & \\
\hline & $\chi$ & \\
\hline \multicolumn{2}{|c|}{$N / A$} & \\
\hline YES & NO & EXPLANATION (required if shaded box is checked) \\
\hline & $\chi$ & \\
\hline
\end{tabular}




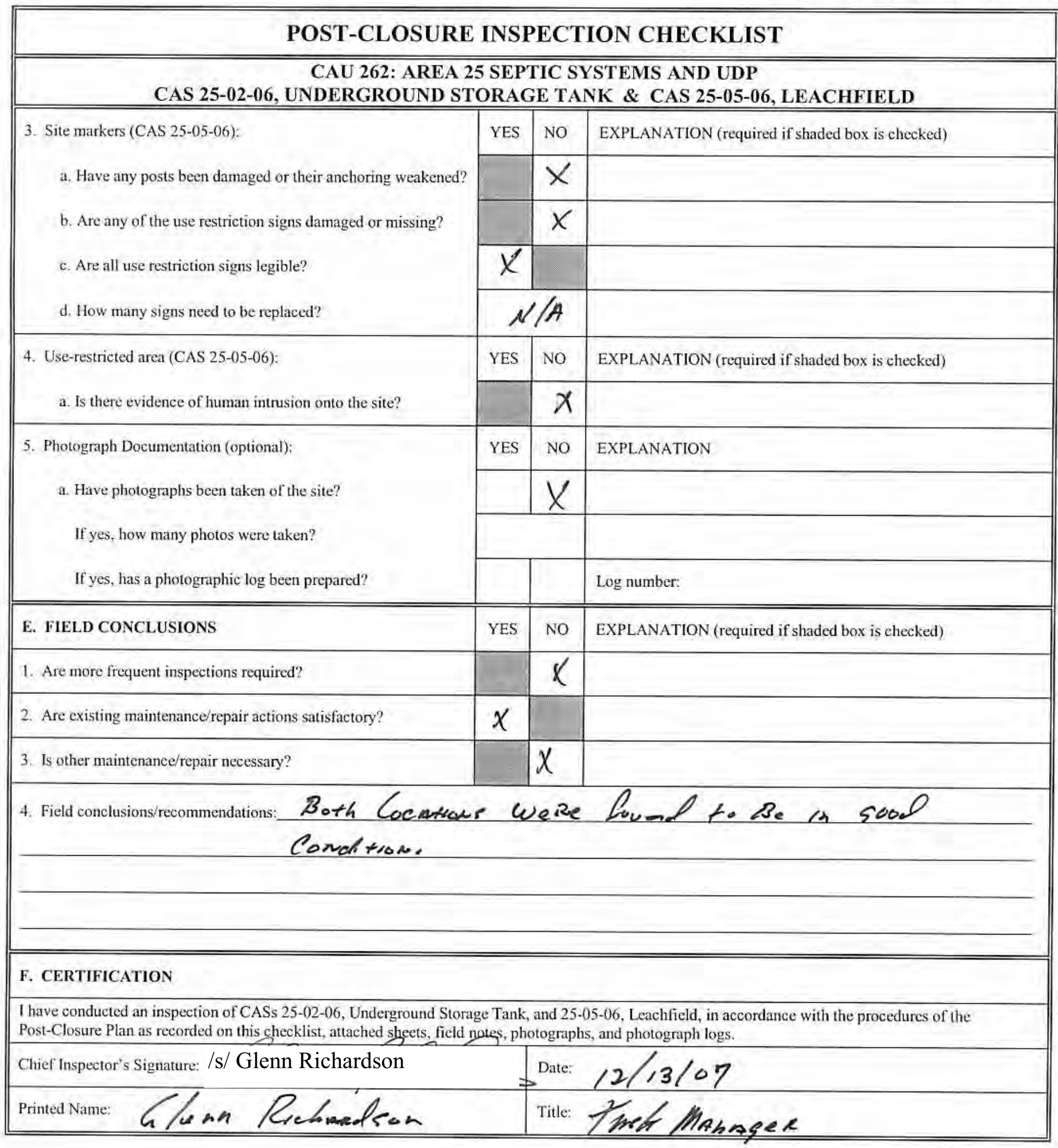




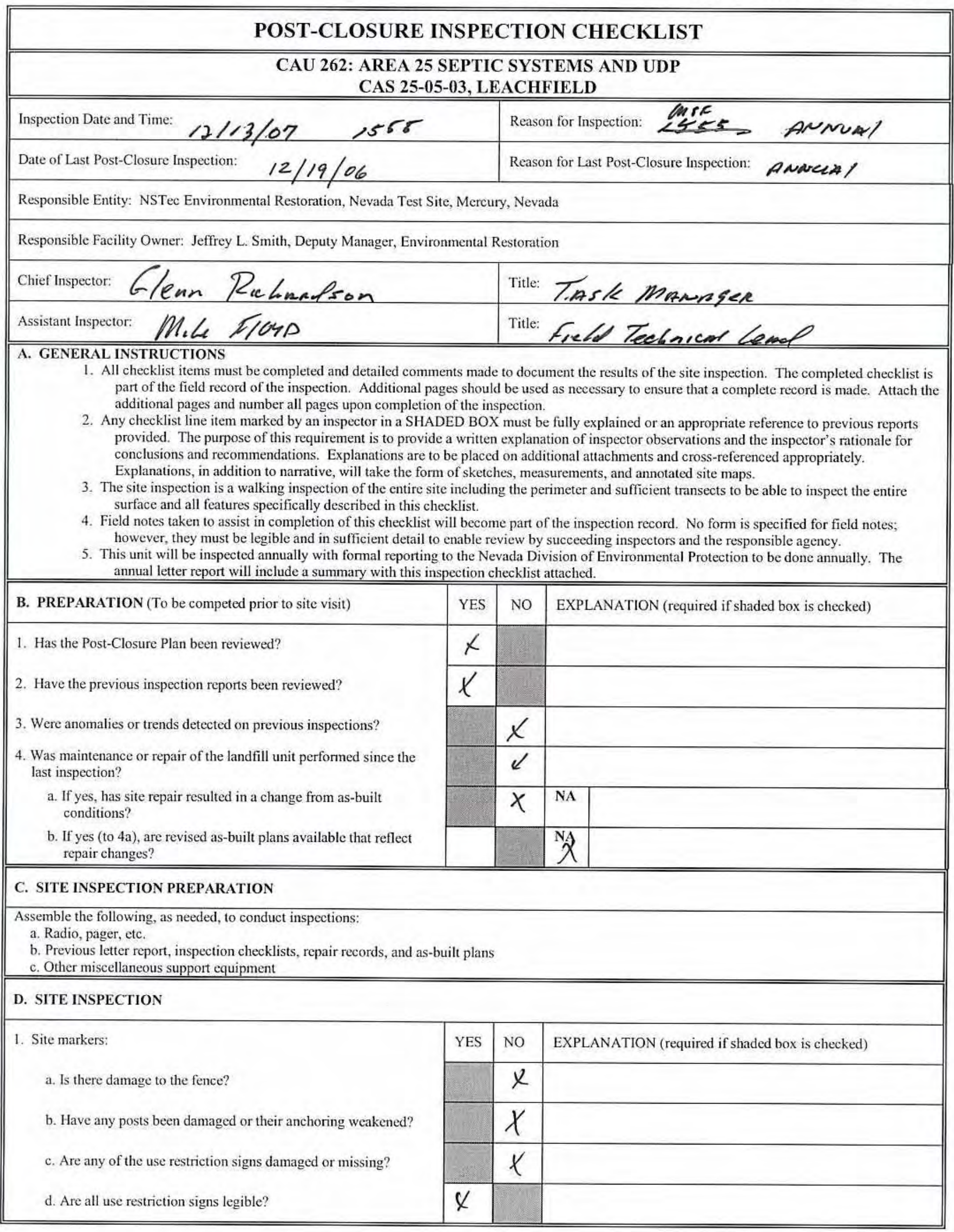




\section{POST-CLOSURE INSPECTION CHECKLIST}

\section{CAU 262: AREA 25 SEPTIC SYSTEMS AND UDP}

\section{CAS 25-05-03, LEACHFIELD}

1. Site markers (continued)

e. How many signs need to be replaced?

2. Waste unit cover:

a. Is there evidence of settling?

b. Is there evidence of erosion (wind or water)?

c. Is there evidence of human intrusion into the cover?

d. Is there evidence of large animal intrusion into the cover?

3. Photograph Documentation (optional):

a. Have photographs been taken of the site?

If yes, how many photos were taken?

If yes, has a photographic log been prepared?

\begin{tabular}{|c|c|c|c|}
\hline E. FIELD CONCLUSIONS & YES & NO & EXPLANATION (required if shaded box is checked) \\
\hline $\begin{array}{l}\text { 1. Is there an imminent hazard to the integrity of the site? } \\
\text { (Immediate report required) }\end{array}$ & & & \\
\hline
\end{tabular}

Date reported:

Person/Agency to whom report was made:

2. Are more frequent inspections required?

3. Are existing maintenance/repair actions satisfactory?

4. Is other maintenance/repair necessary?

5. Field conclusions/recommendations: Thes Lucatrou war taend to Be m puad Cordetian

\section{F. CERTIFICATION}

I have conducted an inspection of CAS 25-05-03, Leachfield, in accordance with the procedures of the Post-Closure Plan as recorded on this checklist, attached sheets, field notes, photographs, and photograph togs.

Chief Inspector's Signature: /s/ Glenn Richardson

Printed Name:

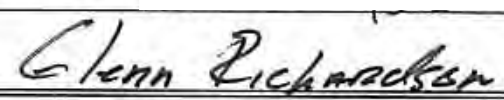

Date: $12 / 13 / 07$




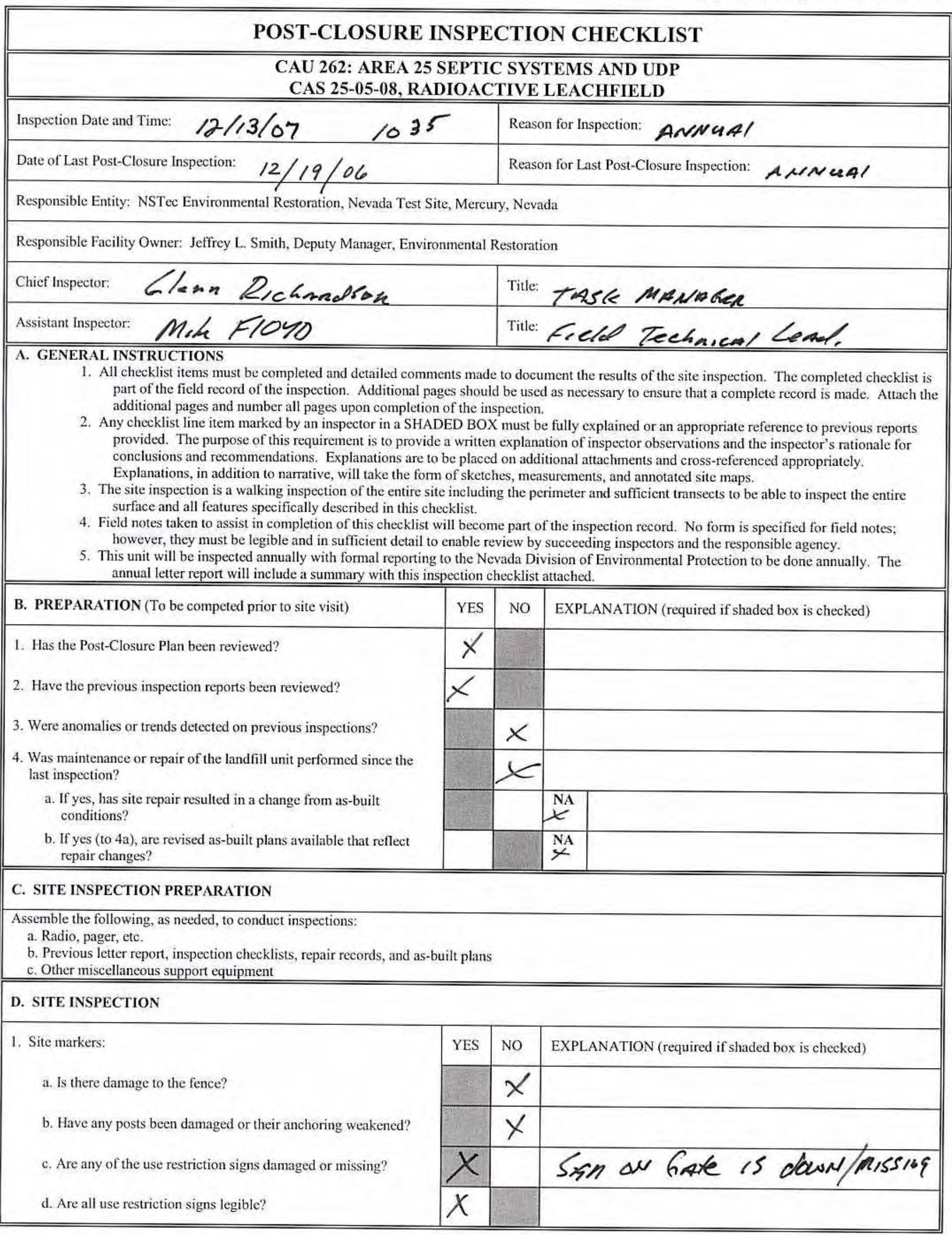




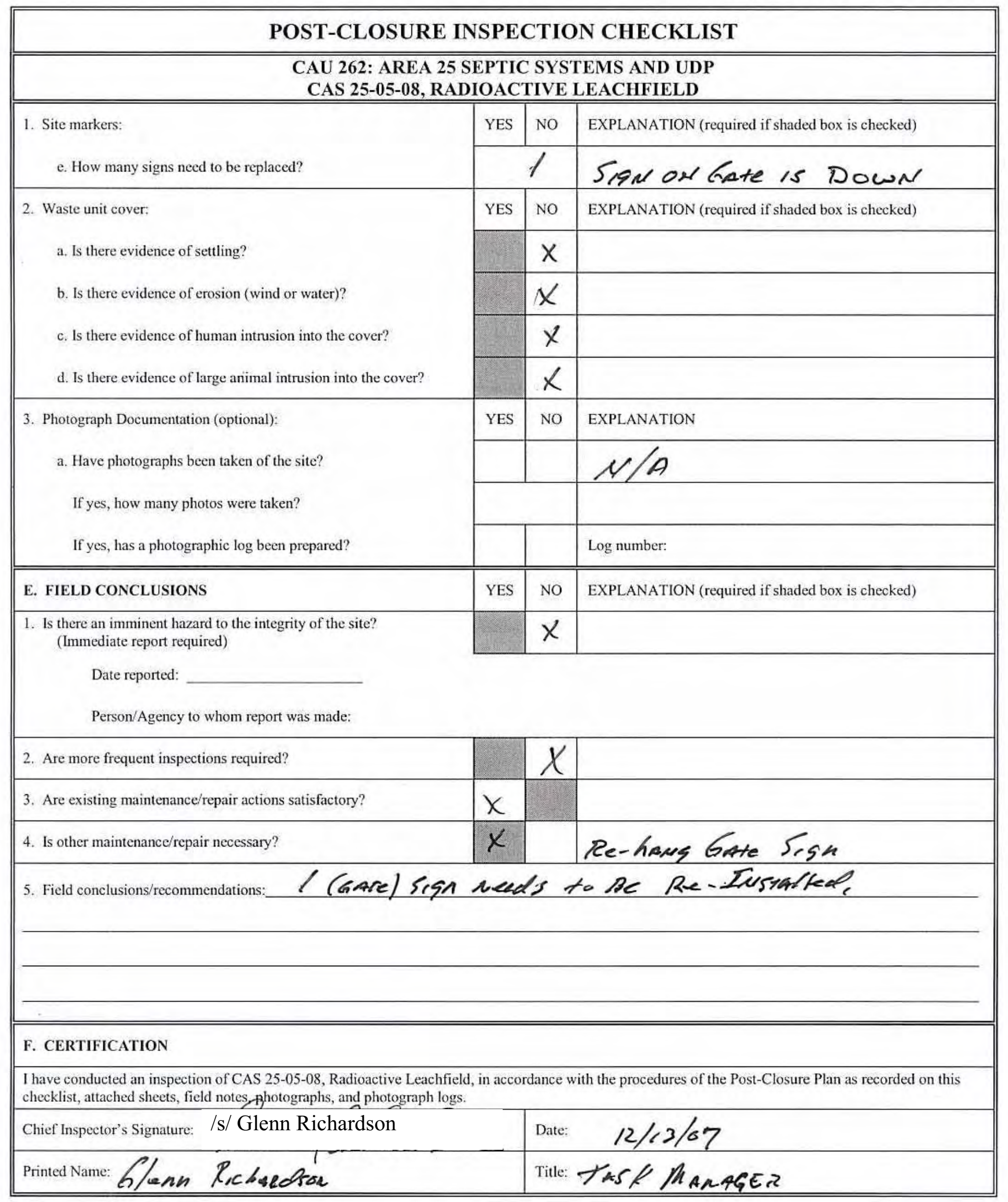




\section{CAU 271: AREAS 25, 26, AND 27 SEPTIC SYSTEMS}




\section{POST-CLOSURE INSPECTION CHECKLIST}

\section{CAU 271: AREAS 25, 26, AND 27 SEPTIC SYSTEMS - CAS 27-05-02, LEACHFIELD}

\begin{tabular}{||l|l|}
\hline \hline Inspection Date and Time: $1 / 23 / 08 \quad 9: 13 A M$ & Reason for Inspection: Annua/ \\
\hline Date of Last Post-Closure Inspection: $1 / 18 / 07$ & Reason for Last Post-Closure Inspection: Annua / \\
\hline
\end{tabular}

Responsible Entity: NSTec Environmental Restoration, Nevada Test Site, Mercury, Nevada

Responsible Facility Owner: Jeffrey L. Smith, Deputy Manager, Environmental Restoration

\begin{tabular}{|l|l|}
\hline Chief Inspector: Glenn Richardson & Title: Task Manager \\
\hline Assistant Inspector: Robert Green & Title: Field Techuical Lead \\
\hline \hline
\end{tabular}

A. GENERAL INSTRUCTIONS

1. All checklist items must be completed and detailed comments made to document the results of the site inspection. The completed checklist is part of the field record of the inspection. Additional pages should be used as necessary to ensure that a complete record is made. Attach the additional pages and number all pages upon completion of the inspection.

2. Any checklist line item marked by an inspector in a SHADED BOX must be fully explained or an appropriate reference to previous reports provided. The purpose of this requirement is to provide a written explanation of inspector observations and the inspector's rationale for conclusions and recommendations. Explanations are to be placed on additional attachments and cross-referenced appropriately. Explanations, in addition to narrative, will take the form of sketches, measurements, and annotated site maps.

3. The site inspection is a walking inspection of the entire site including the perimeter and sufficient transects to be able to inspect the entire surface and all features specifically described in this checklist.

4. Field notes taken to assist in completion of this checklist will become part of the inspection record. No form is specified for field notes; however, they must be legible and in sufficient detail to enable review by succeeding inspectors and the responsible agency.

5. This unit will be inspected annually with formal reporting to the Nevada Division of Environmental Protection to be done annually. The annual letter report will include a summary with this inspection checklist attached.

\begin{tabular}{|c|c|c|c|}
\hline B. PREPARATION (To be competed prior to site visit) & YES & NO & EXPLANATION (required if shaded box is checked) \\
\hline 1. Has the Post-Closure Plan been reviewed? & & & \\
\hline 2. Have the previous inspection reports been reviewed? & & & \\
\hline 3. Were anomalies or trends detected on previous inspections? & & & \\
\hline 4. Were maintenance or repairs performed since last inspection? & & & \\
\hline
\end{tabular}

\section{SITE INSPECTION PREPARATION}

Assemble the following, as needed, to conduct inspections:
a. Radio, pager, etc.
b. Previous letter report, inspection checklists, repair records, and as-built plans
c. Other miscellaneous support equipment

\section{SITE INSPECTION}

1. Site markers:
a. Is there damage to the fence?
b. Have any posts been damaged or their anchoring weakened?
c. Are any of the 4 use restriction signs damaged or missing?
d. Are all use restriction signs legible?
e. How many signs need to be replaced?

\begin{tabular}{|l|l|l||}
\hline YES & NO & EXPLANATION (required if shaded box is checked) \\
\hline & & \\
\hline & & \\
\hline & & \\
\hline & & \\
\hline
\end{tabular}




\begin{tabular}{|c|c|c|c|}
\hline \multicolumn{4}{|c|}{ POST-CLOSURE INSPECTION CHECKLIST } \\
\hline \multicolumn{4}{|c|}{ CAU 271: AREAS 25, 26, AND 27 SEPTIC SYSTEMS - CAS 27-05-02, LEACHFIELD } \\
\hline \multirow{2}{*}{$\begin{array}{l}\text { 2. Use-restricted area: } \\
\text { a. Is there evidence of human intrusion onto the site? }\end{array}$} & YES & No & EXPLANATION (required if shaded box is checked) \\
\hline & & $\checkmark$ & \\
\hline \multirow{2}{*}{$\begin{array}{l}\text { 3. Photograph Documentation (optional): } \\
\text { a. Have photographs been taken of the site? }\end{array}$} & YES & NO & EXPLANATION \\
\hline & & $\checkmark$ & \\
\hline \multicolumn{4}{|l|}{ If yes, how many photos were taken? } \\
\hline If yes, has a photographic log been prepared? & & & Log number: \\
\hline E. FIELD CONCLUSIONS & YES & NO & EXPLANATION (required if shaded box is checked) \\
\hline \multicolumn{4}{|l|}{ 1. Are more frequent inspections required? } \\
\hline \multicolumn{4}{|l|}{ 2. Are existing maintenance/repair actions satisfactory? } \\
\hline \multicolumn{4}{|l|}{ 3. Is other maintenance/repair necessary? } \\
\hline \multirow{2}{*}{\multicolumn{4}{|c|}{$\begin{array}{l}\text { 4. Field conclusions/recommendations: The use restriction signs and } 7 \\
\text { excellent condition. There is no evidence of int } \\
\text { site. Therefore, no follow-up actions are required. }\end{array}$}} \\
\hline & & & \\
\hline \multicolumn{4}{|l|}{ F. CERTIFICATION } \\
\hline \multicolumn{4}{|c|}{$\begin{array}{l}1 \text { have conducted an inspection of CAS 27-05-02, Leachfield, in accordance with the procedures of the Post-Closure Plan as recorded on this checklist, } \\
\text { attached sheets, field notes, photographs, and photograph logs. }\end{array}$} \\
\hline Chief Inspector's Signature: /s/ Glenn Richardson & & Date: & $1 / 23 / 08$ \\
\hline Printed Name: Glenn Richardson & & Title: & Task Manager \\
\hline
\end{tabular}


CAU 309: AREA 12 MUCKPILES 


\section{POST-CLOSURE INSPECTION CHECKLIST}

\section{CAU 309: AREA 12 MUCKPILES - CAS 12-06-09, MUCKPILE \\ CAS 12-08-02, CWD \\ CAS 12-28-01, I, J, AND K-TUNNEL DEBRIS}

\begin{tabular}{|l|l|}
\hline Inspection Date and Time: $2 / 12 / 08$ & Reason for Inspection: Annua/ \\
\hline Date of Last Post-Closure Inspection: None & Reason for Last Post-Closure Inspection:
\end{tabular}

Responsible Entity: NSTec Environmental Restoration, Nevada Test Site, Mercury, Nevada

Responsible Facility Owner: Jeffrey L. Smith, Deputy Manager, Environmental Restoration

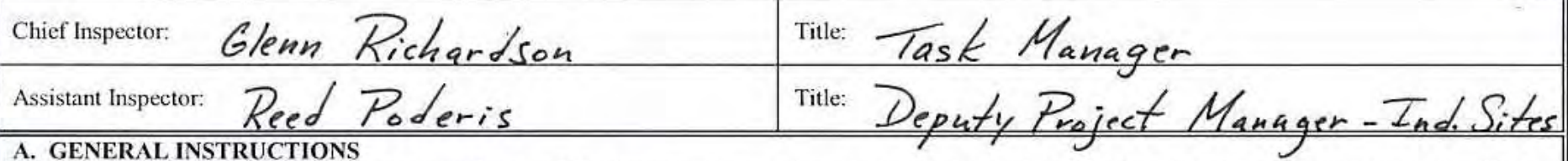

A. GENERAL INSTRUCTIONS

1. All checklist items must be completed and detailed comments made to document the results of the site inspection. The completed checklist is part of the field record of the inspection. Additional pages should be used as necessary to ensure that a complete record is made. Attach the additional pages and number all pages upon completion of the inspection.

2. Any checklist line item marked by an inspector in a SHADED BOX must be fully explained or an appropriate reference to previous reports provided. The purpose of this requirement is to provide a written explanation of inspector observations and the inspector's rationale for conclusions and recommendations. Explanations are to be placed on additional attachments and cross-referenced appropriately. Explanations, in addition to narrative, will take the form of sketches, measurements, and annotated site maps.

3. The site inspection is a walking inspection of the entire site including the perimeter and sufficient transects to be able to inspect the entire surface and all features specifically described in this checklist.

4. Field notes taken to assist in completion of this checklist will become part of the inspection record. No form is specified for field notes: however, they must be legible and in sufficient detail to enable review by succeeding inspectors and the responsible agency.

5. This unit will be inspected annually with formal reporting to the Nevada Division of Environmental Protection to be done annually. The annual letter report will include a summary with this inspection checklist attached.

B. PREPARATION (To be competed prior to site visit)

1. Has the Post-Closure Plan been reviewed?

2. Have the previous inspection reports been reviewed?

3. Were anomalies or trends detected on previous inspections?

4. Were maintenance or repairs performed since last inspection?

\begin{tabular}{|l|l|l||}
\hline YES & NO & EXPLANATION (required if shaded box is checked) \\
\hline & & \\
\hline & \multicolumn{1}{|c|}{$\begin{array}{l}\text { This is the first annual post closure } \\
\text { inspection by NSTec ER. }\end{array}$} \\
\hline & & \\
\hline
\end{tabular}

\section{SITE INSPECTION PREPARATION}

Assemble the following, as needed, to conduct inspections

a. Radio, pager, etc.

b. Previous letter report, inspection checklists, repair records, and as-built plans

c. Other miscellaneous support equipment

\section{SITE INSPECTION}

1. Site markers (CAS 12-06-09):

a. Have any posts been damaged or their anchoring weakened?

b. Are any of the use restriction signs damaged or missing?

c. Are all use restriction signs legible?

d. How many signs need to be replaced?

2. Site markers (CAS 12-08-02):

a. Have any posts been damaged or their anchoring weakened?

\begin{tabular}{|c|c|c|}
\hline YES & NO & EXPLANATION (required if shaded box is checked) \\
\hline & $V$ & $\begin{array}{l}\text { Noticed a few radiological signs that need } \\
\text { replacement. UR signs are in aeed condition }\end{array}$ \\
\hline \multicolumn{2}{|c|}{0} & \\
\hline YES & NO & EXPLANATION (required if shaded box is checked) \\
\hline & & \\
\hline
\end{tabular}




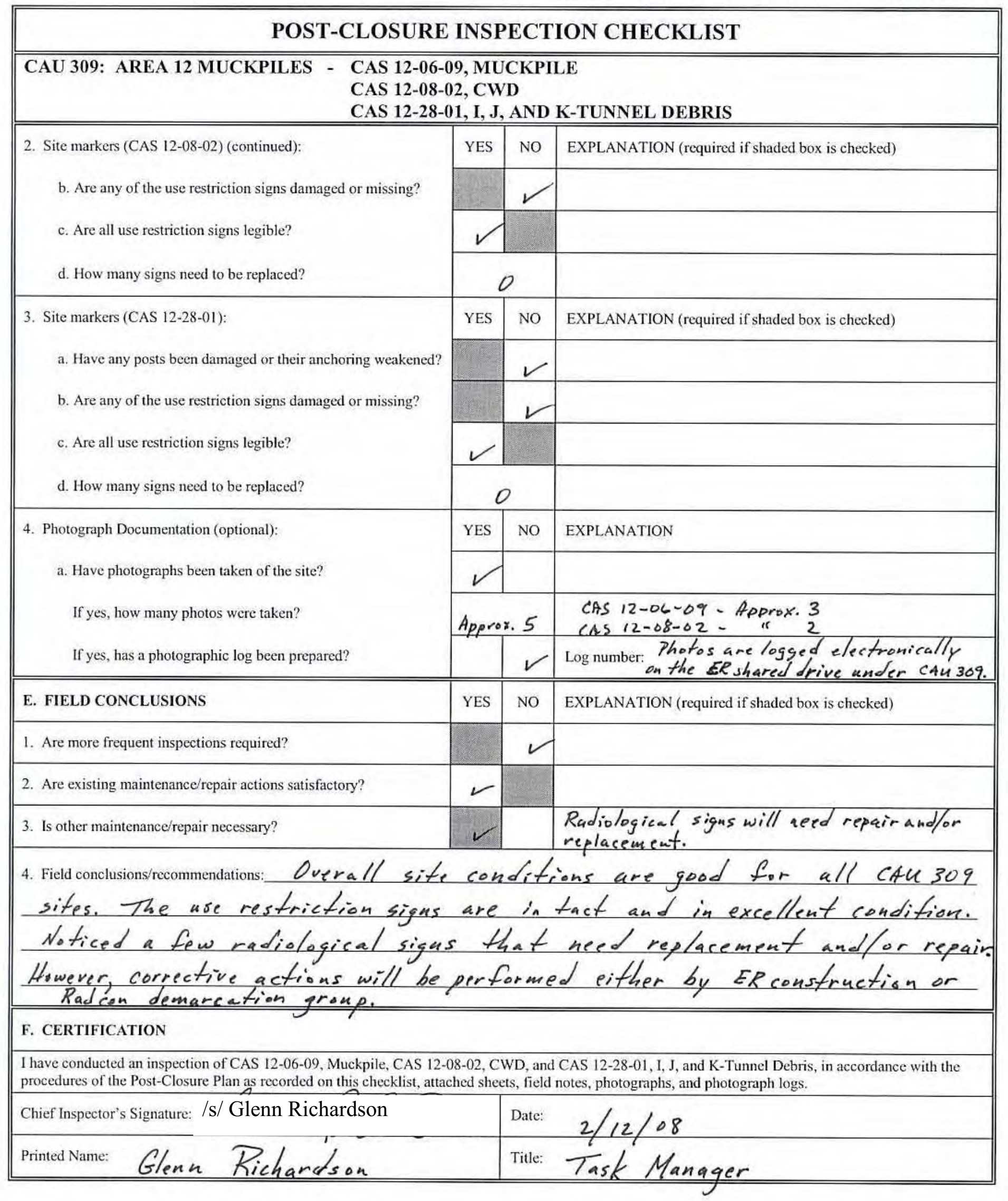


CAU 322: AREAS 1 \& 3 RELEASE SITES AND INJECTION WELLS 


\section{POST-CLOSURE INSPECTION CHECKLIST}

\section{CAU 322: AREAS 1 \& 3 RELEASE SITES AND INJECTION WELLS CAS 01-25-01, AST RELEASE}

\begin{tabular}{|c|c|}
\hline Inspection Date and Time: & Reason for Inspection: \\
\hline Date of Last Post-Closure Inspection: $1 / 3 / 07$ & Reason for Last Post-Closure Inspection: \\
\hline
\end{tabular}

Responsible Entity: NSTec Environmental Restoration, Nevada Test Site, Mercury, Nevada

Responsible Facility Owner: Jeffrey L. Smith, Deputy Manager, Environmental Restoration

\begin{tabular}{l|l} 
Chief Inspector: Gleun Richardson & Title: Task Manager \\
Assistant Inspector: Brian Konrad & Title: ER Field Operatio
\end{tabular}

A. GENERAL INSTRUCTIONS

1. All checklist items must be completed and detailed comments made to document the results of the site inspection. The completed checklist is part of the field record of the inspection. Additional pages should be used as necessary to ensure that a complete record is made. Attach the additional pages and number all pages upon completion of the inspection.

2. Any checklist line item marked by an inspector in a SHADED BOX must be fully explained or an appropriate reference to previous reports provided. The purpose of this requirement is to provide a written explanation of inspector observations and the inspector's rationale for conclusions and recommendations. Explanations are to be placed on additional attachments and cross-referenced appropriately. Explanations, in addition to narrative, will take the form of sketches, measurements, and annotated site maps.

3. The site inspection is a walking inspection of the entire site including the perimeter and sufficient transects to be able to inspect the entire surface and all features specifically described in this checklist.

4. Field notes taken to assist in completion of this checklist will become part of the inspection record. No form is specified for field notes; however, they must be legible and in sufficient detail to enable review by succeeding inspectors and the responsible agency.

5. This unit will be inspected annually with formal reporting to the Nevada Division of Environmental Protection to be done annually. The annual letter report will include a summary with this inspection checklist attached

B. PREPARATION (To be competed prior to site visit)

1. Has the Post-Closure Plan been reviewed?

2. Have the previous inspection reports been reviewed?

3. Were anomalies or trends detected on previous inspections?

4. Were maintenance or repairs performed since last inspection?

a. If yes, obtain a copy of maintenance records and attach to checklist.

\begin{tabular}{|l|l|l|l|} 
YES & NO & \multicolumn{2}{|l|}{ EXPLANATION (required if shaded box is checked) } \\
\hline & & \\
\hline & & \\
\hline & & \\
\hline
\end{tabular}

\section{SITE INSPECTION PREPARATION}

Assemble the following, as needed, to conduct inspections:

a. Radio, pager, etc.

b. Previous letter report, inspection checklists, repair records, and as-built plans

c. Other miscellaneous support equipment

\section{SITE INSPECTION}

1. Site markers:

a. Is there damage to the fence?

b. Have any posts been damaged or their anchoring weakened?

c. Are any of the 4 use restriction signs damaged or missing?

d. Are all use restriction signs legible?

e. How many signs need to be replaced?

\begin{tabular}{|l|l|l||}
\hline YES & NO & EXPLANATION (required if shaded box is checked) \\
\hline & & \\
\hline & & \\
\hline & & \\
\hline & & \\
\hline
\end{tabular}




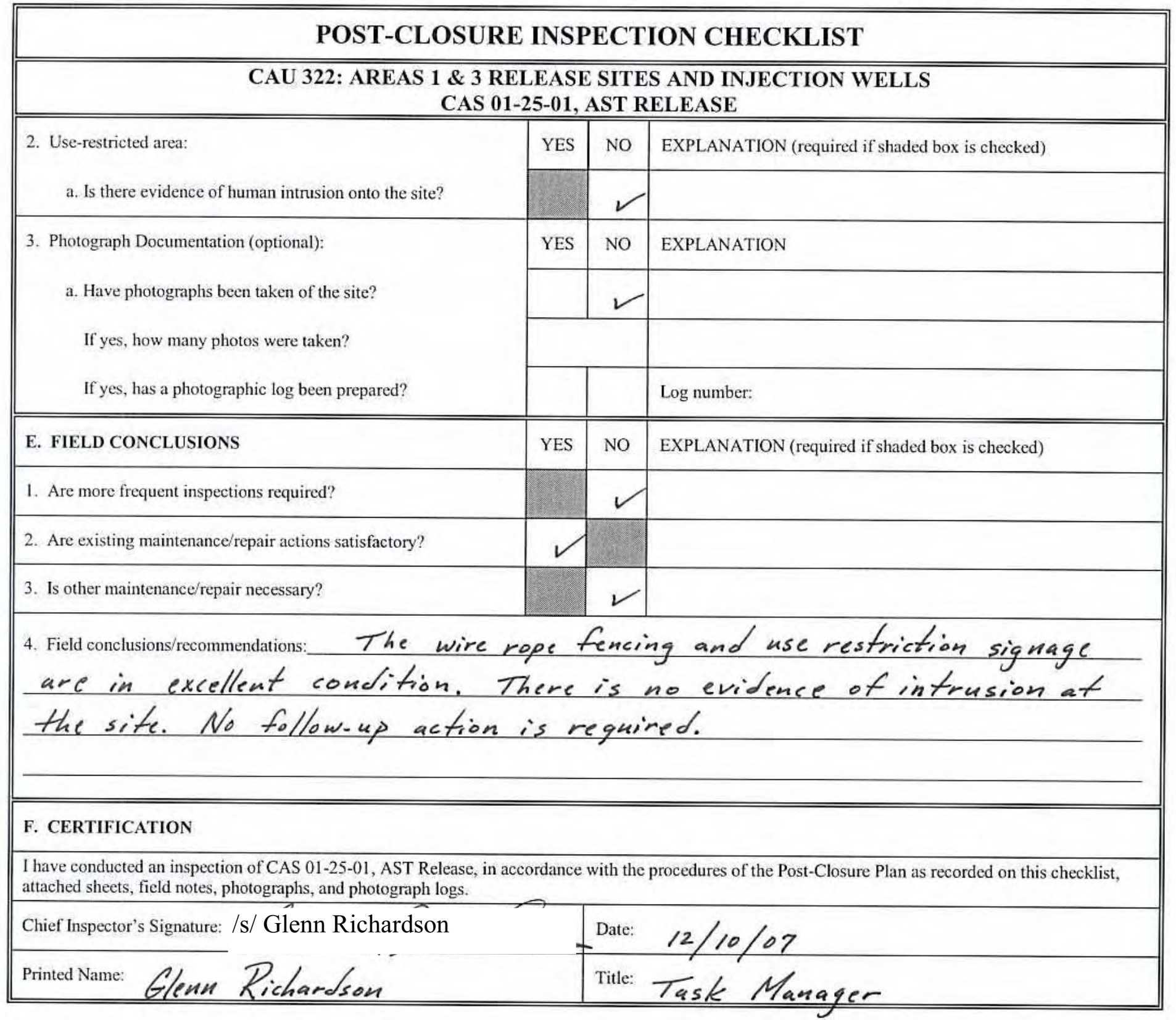

Attachments (check if attached):

$\square$ Maintenance records 


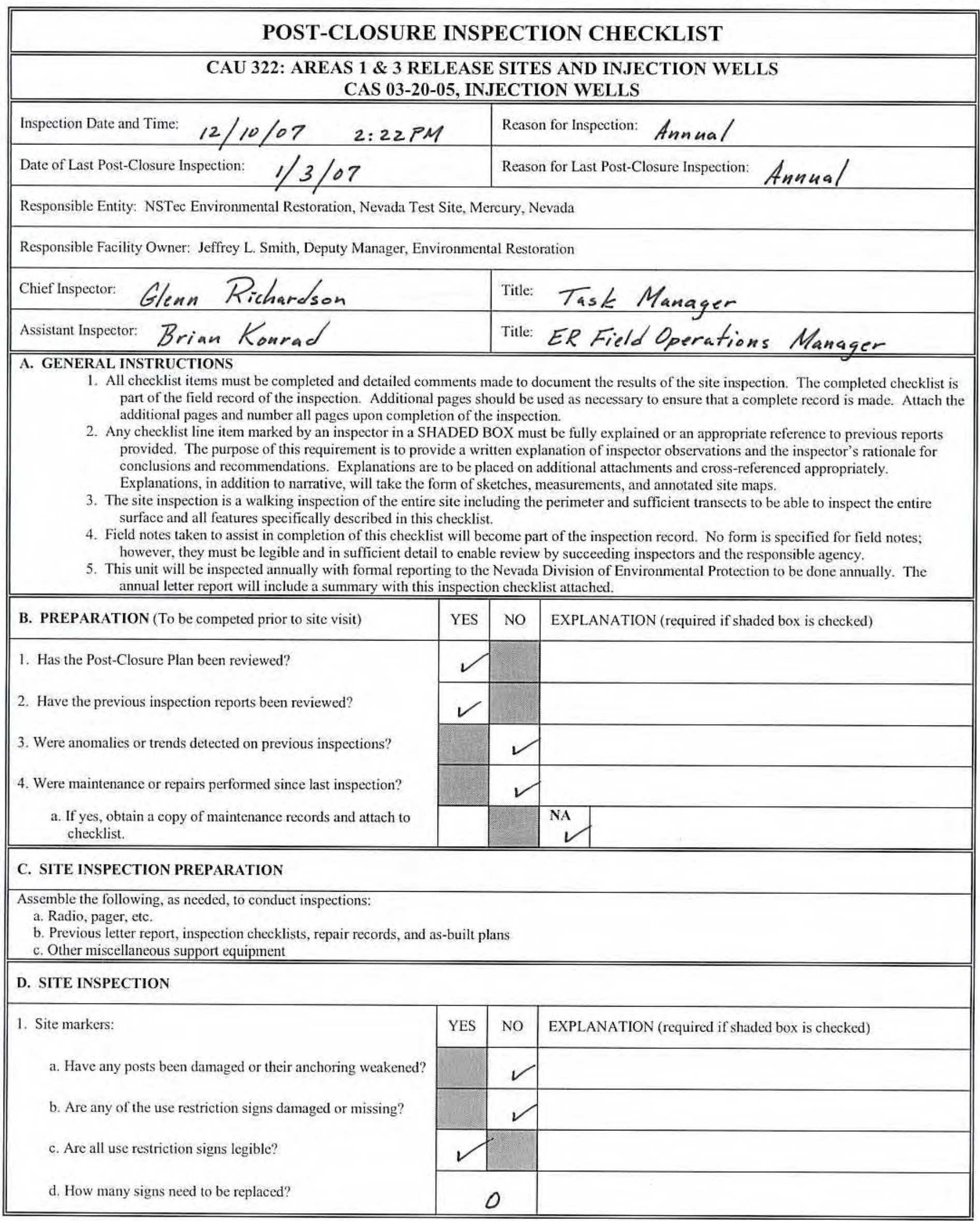




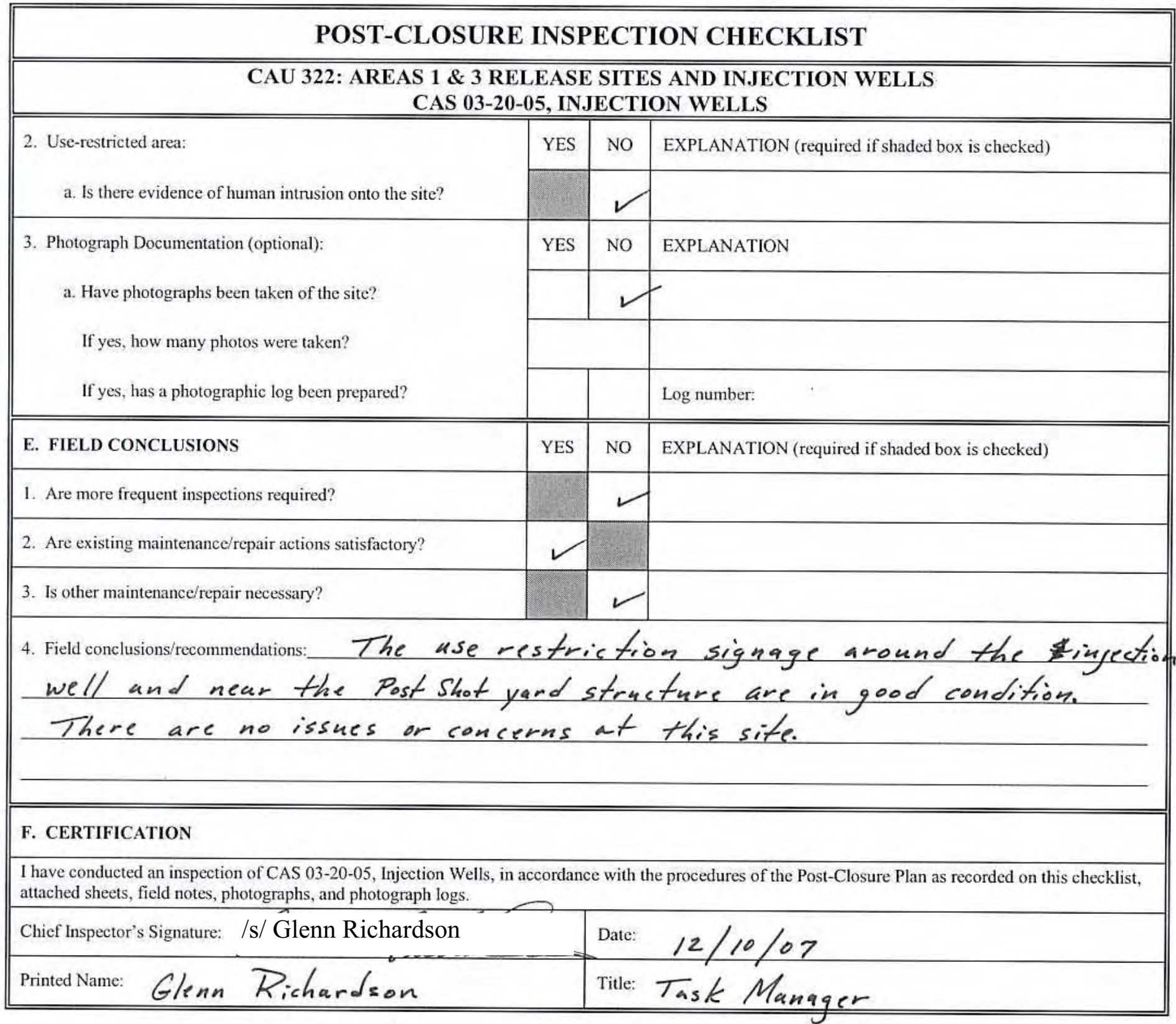

Attachments (check if attached):

$\square$ Maintenance records 


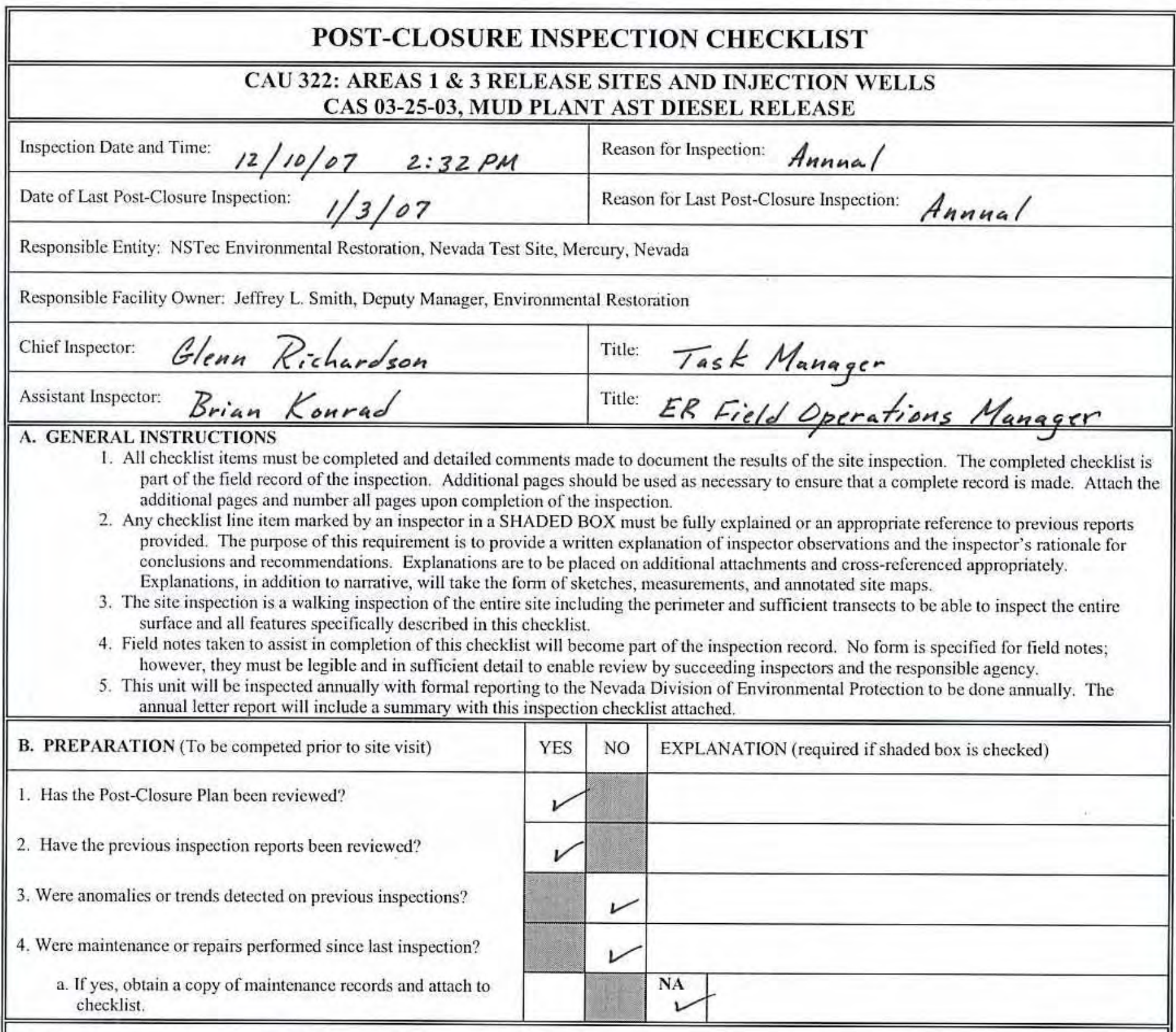

\section{SITE INSPECTION PREPARATION}

Assemble the following, as needed, to conduct inspections:

a. Radio, pager, etc.

b. Previous letter report, inspection checklists, repair records, and as-built plans

c. Other miscellaneous support equipment

\section{SITE INSPECTION}

1. Site markers:

a. Is there damage to the fence?

b. Have any posts been damaged or their anchoring weakened?

c. Are any of the 6 use restriction signs damaged or missing?

d. Are all use restriction signs legible?

e. How many signs need to be replaced?

\begin{tabular}{|l|l|l||}
\hline YES & NO & EXPLANATION (required if shaded box is checked) \\
\hline & & \\
\hline & & \\
\hline & & \\
\hline & & \\
\hline & & \\
\hline
\end{tabular}




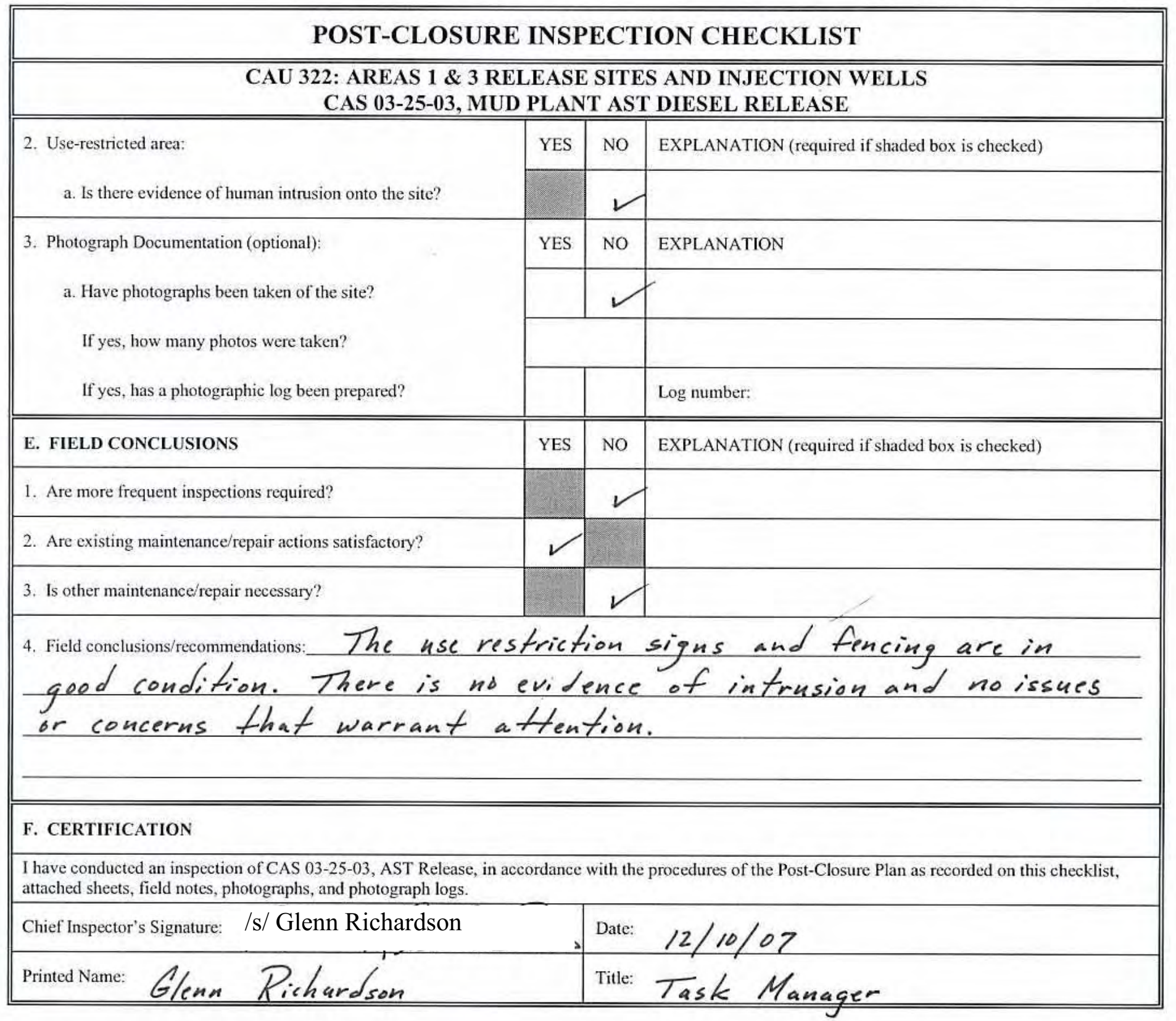

Attachments (check if attached):

$\square$ Maintenance records 


\section{CAU 335: AREA 6 INJECTION WELL AND DRAIN PIT}




\begin{tabular}{|c|c|c|c|}
\hline \multicolumn{4}{|c|}{ POST-CLOSURE INSPECTION CHECKLIST } \\
\hline \multicolumn{4}{|c|}{$\begin{array}{l}\text { CAU 335: AREA 6 INJECTION WELL AND DRAIN PIT } \\
\text { CAS 06-20-02, 20-INCH CASED HOLE \& CAS 06-23-03, DRAIN PIT } \\
\end{array}$} \\
\hline \multicolumn{2}{|l|}{ Inspection Date and Time: } & \multicolumn{2}{|c|}{ Reason for Inspection: Anиua/ } \\
\hline \multicolumn{2}{|l|}{ Date of Last Post-Closure Inspection: } & \multicolumn{2}{|c|}{ Reason for Last Post-Closure Inspection: Anииа/ } \\
\hline \multicolumn{4}{|c|}{ Responsible Entity: NSTec Environmental Restoration, Nevada Test Site, Mercury, Nevada } \\
\hline \multicolumn{4}{|c|}{ Responsible Facility Owner: Jeffrey L. Smith, Deputy Manager, Environmental Restoration } \\
\hline \multicolumn{2}{|l|}{ Chief Inspector: Glenn Kichardson } & \multicolumn{2}{|c|}{ Title: Task Manager } \\
\hline \multicolumn{2}{|l|}{ Assistant Inspector: Brian Kourad } & \multicolumn{2}{|c|}{ Title: ER Field Operations Manaqer } \\
\hline \multicolumn{4}{|c|}{$\begin{array}{l}\text { A. GENERAL INSTRUCTIONS } \\
\text { 1. All checklist items must be completed and detailed comments made to document the results of the site inspection. The completed checklist } \\
\text { part of the field record of the inspection. Additional pages should be used as necessary to ensure that a complete record is made. Attach t } \\
\text { additional pages and number all pages upon completion of the inspection. } \\
\text { 2. Any checklist line item marked by an inspector in a SHADED BOX must be fully explained or an appropriate reference to previous reports } \\
\text { provided. The purpose of this requirement is to provide a written explanation of inspector observations and the inspector's rationale for } \\
\text { conclusions and recommendations. Explanations are to be placed on additional attachments and cross-referenced appropriately. } \\
\text { Explanations, in addition to narrative, will take the form of sketches, measurements, and annotated site maps. } \\
\text { 3. The site inspection is a walking inspection of the entire site including the perimeter and sufficient transects to be able to inspect the entire } \\
\text { surface and all features specifically described in this checklist. } \\
\text { 4. Field notes taken to assist in completion of this checklist will become part of the inspection record. No form is specified for field notes; } \\
\text { however, they must be legible and in sufficient detail to cnable review by succeeding inspectors and the responsible agency. } \\
\text { 5. This unit will be inspected annually with formal reporting to the Nevada Division of Environmental Protection to be done annually. The } \\
\text { annual letter report will include a summary with this inspection checklist attached. }\end{array}$} \\
\hline B. PREPARATION (To be competed prior to site visit) & YES & NO & EXPLANATION (required if shaded box is checked) \\
\hline \multicolumn{4}{|l|}{ 1. Has the Post-Closure Plan been reviewed? } \\
\hline \\
\hline \multirow{3}{*}{$\begin{array}{l}\text { 3. Were anomalies or trends detected on previous inspections? } \\
\text { 4. Were maintenance or repairs performed since last inspection? } \\
\text { a. If yes, obtain a copy of maintenance records and attach to } \\
\text { checklist. }\end{array}$} & & & $\begin{array}{l}\text { On previous inspections, signs have had to be } \\
\text { replaced due to high wind damage. }\end{array}$ \\
\hline & & & $\begin{array}{l}\text { Since the last inspection, new sign and T-post } \\
\text { installations were completed on } 9 / 19 / 07 \text {. }\end{array}$ \\
\hline & & & \begin{tabular}{|l|l|} 
NA & Mintenance records such as the work pkg. \\
& cover sheet, traveler, PTHR, and daily field \\
\end{tabular} \\
\hline \multicolumn{4}{|c|}{ C. SITE INSPECTION PREPARATION Teport are effached. } \\
\hline \multicolumn{4}{|c|}{$\begin{array}{l}\text { Assemble the following, as needed, to conduct inspections: } \\
\text { a. Radio, pager, etc. } \\
\text { b. Previous letter report, inspection checklists, repair records, and as-built plans } \\
\text { c. Other miscellaneous support equipment }\end{array}$} \\
\hline \multicolumn{4}{|l|}{ D. SITE INSPECTION } \\
\hline \multirow{5}{*}{$\begin{array}{l}\text { 1. Site markers (CAS 06-20-02, north of Road 6-06): } \\
\text { a. Have any posts been damaged or their anchoring weakened? }\end{array}$} & YES & NO & EXPLANATION (required if shaded box is checked) \\
\hline & & & \\
\hline & & & \\
\hline & $\checkmark$ & & \\
\hline & & & \\
\hline
\end{tabular}




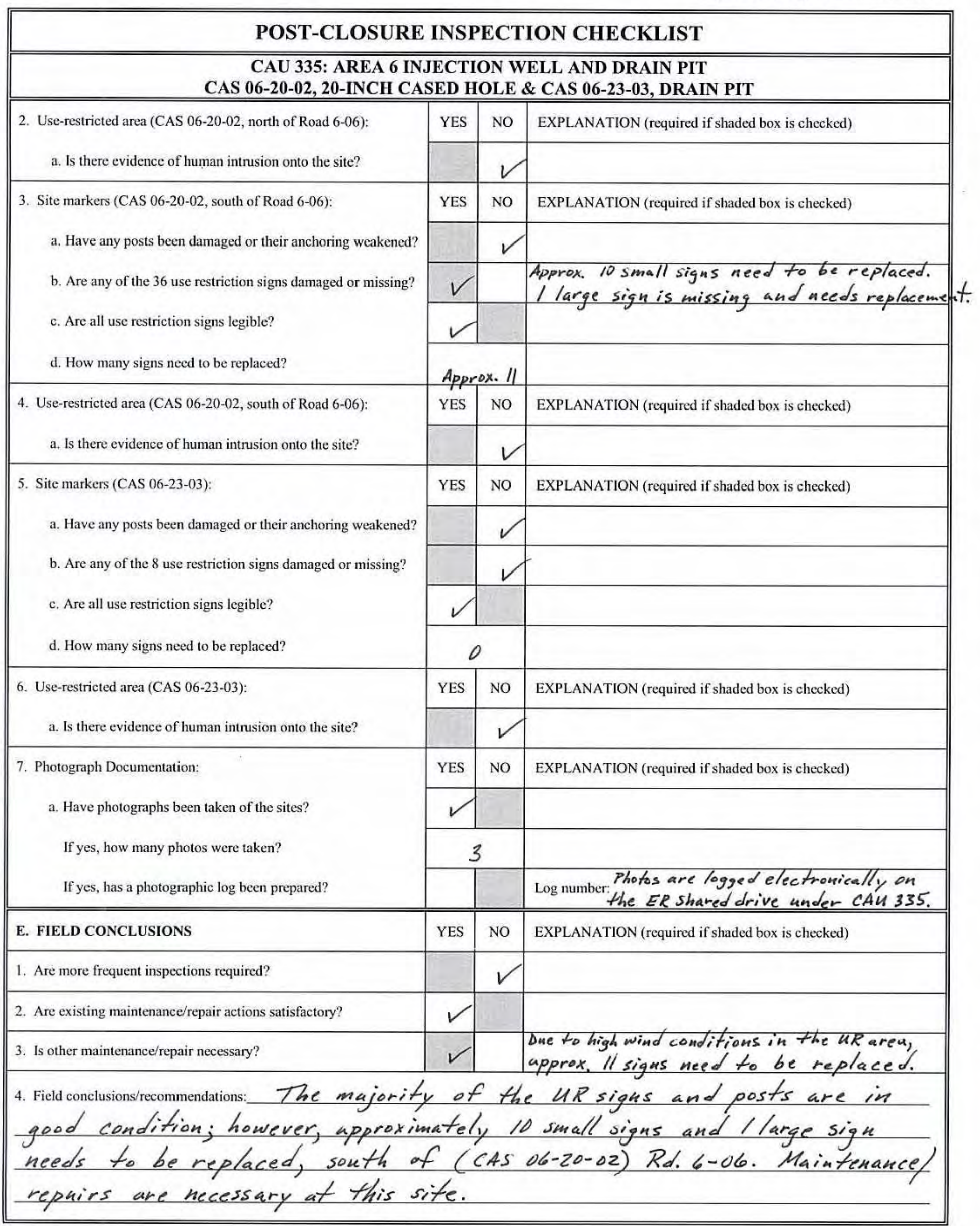




\begin{tabular}{|c|c|}
\hline \multicolumn{2}{|c|}{ POST-CLOSURE INSPECTION CHECKLIST } \\
\hline \multicolumn{2}{|c|}{$\begin{array}{c}\text { CAU 335: AREA } 6 \text { INJECTION WELL AND DRAIN PIT } \\
\text { CAS 06-20-02, 20-INCH CASED HOLE \& CAS 06-23-03, DRAIN PIT }\end{array}$} \\
\hline \multicolumn{2}{|l|}{ F. CERTIFICATION } \\
\hline \multicolumn{2}{|c|}{$\begin{array}{l}\text { I have conducted an inspection of CAU 335, Area } 6 \text { Injection Well and Drain Pit (both CASs), in accordance with the procedures of the Post-Closure Plan as } \\
\text { recorded on this checklist, attached sheets, field notes, photographs, and photograph logs. }\end{array}$} \\
\hline Chief Inspector's Signature: /s/ Glenn Richardson & Date: $12 / 10 / 07$ \\
\hline Printed Name: Glenn Richardson & Title: Task Manager \\
\hline
\end{tabular}

Attachments (check if attached):
■ Maintenance records
[ Photos
G Field notes 
CAU 335, Area 6 Injection Well and Drain Pit

CAS 06-20-02, 20-INCH CASED HOLE

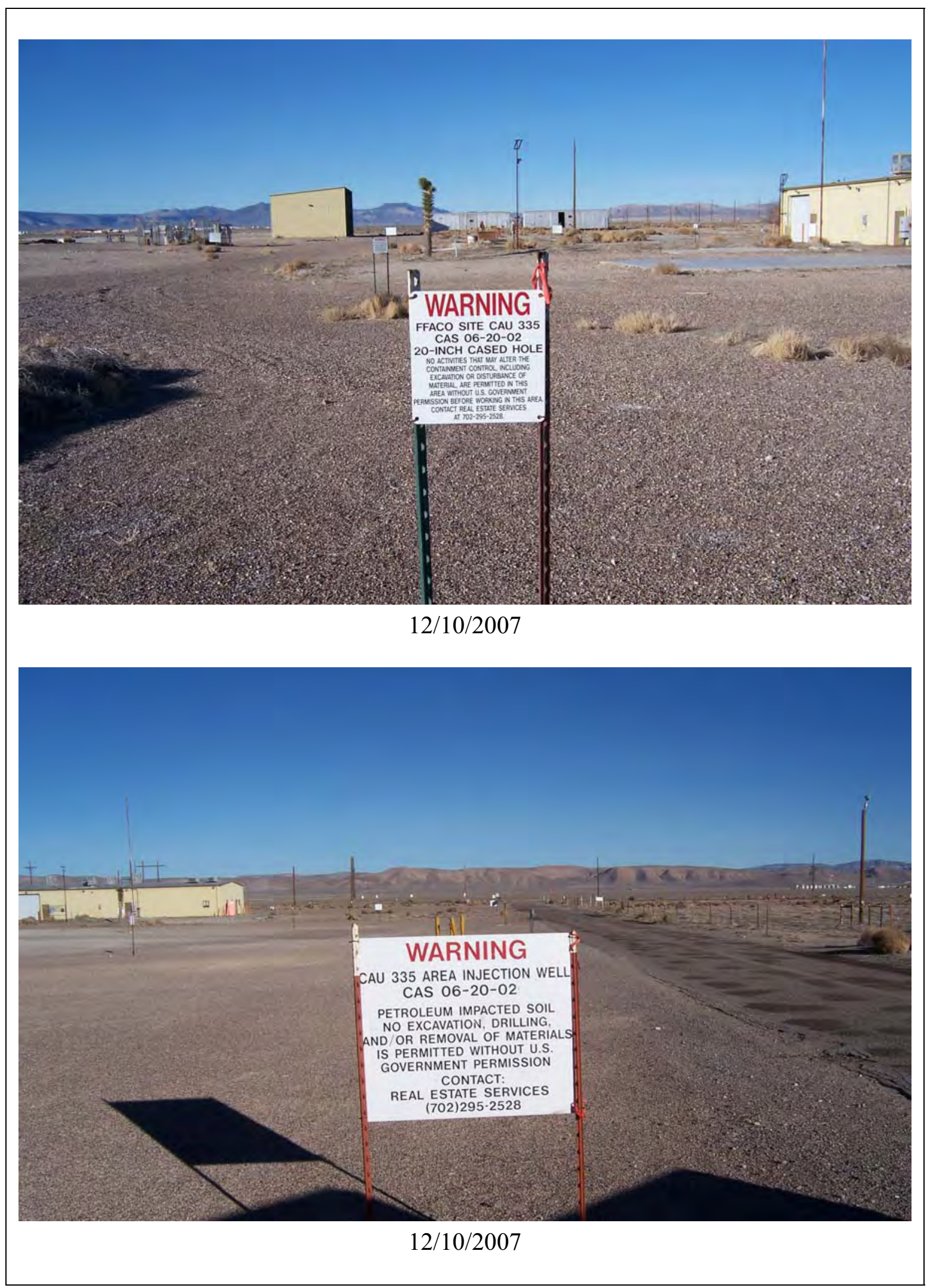


CAU 335, Area 6 InJection Well ANd Drain Pit

CAS 06-23-03, DRAIN PIT

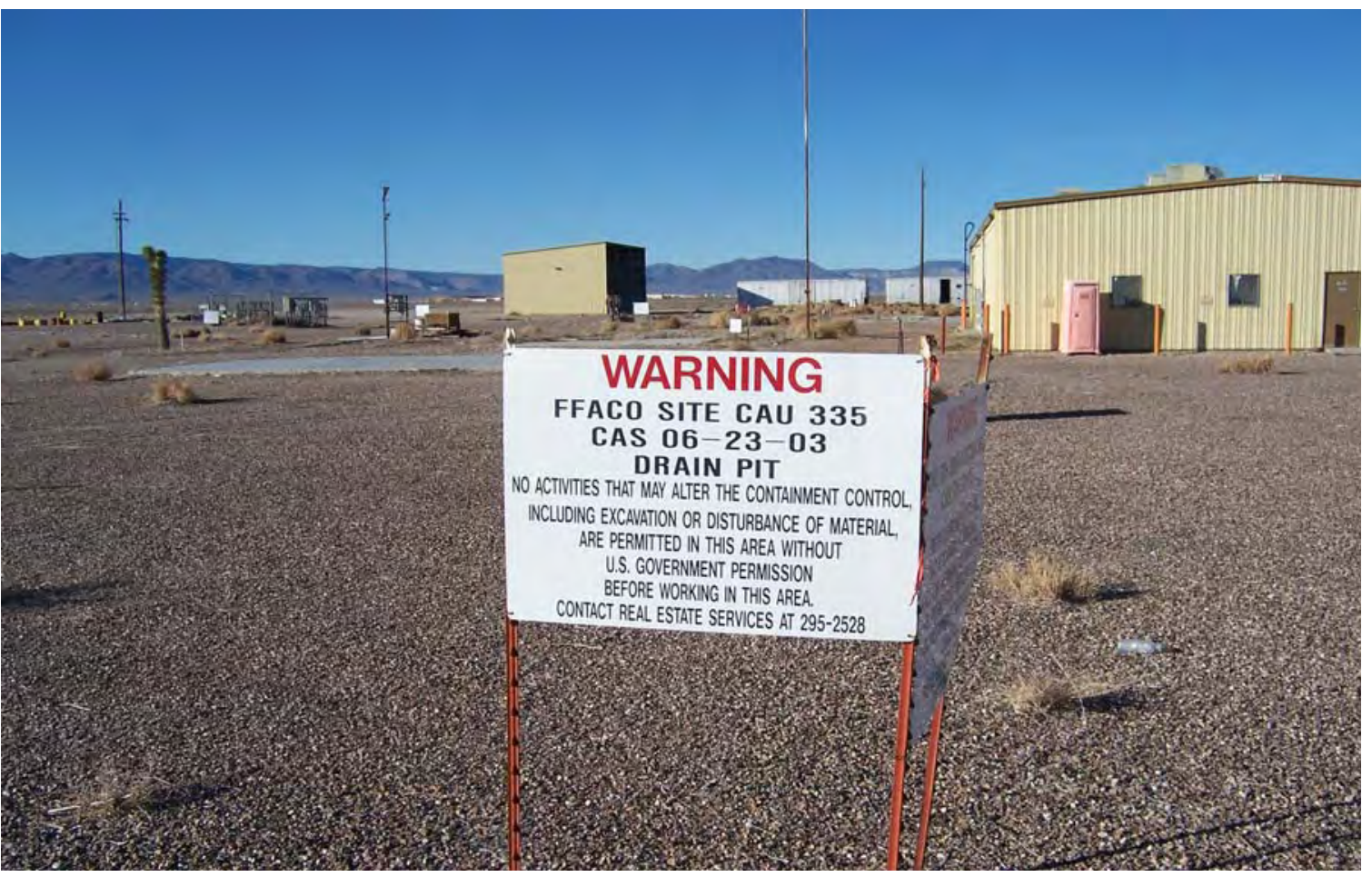

$12 / 10 / 2007$ 
TITLE

Work continued from Page 20
PROJECT NO.

BOOK NO.

21

The site has no issues or concerns that warrant attention.

Leaving the site at $2.35 \mathrm{PH}$.

CAM 335

CAS 06-23-03 Arrived C the site at 2:42 PM. Drove around the

5 posted area to determine the UR signage and t-posts are in good condition. No issues or concerns at this site.

CAS 06-20-02 Arrived $C$ the site at 2:47 PM. Drove around the fenced area and noticed approx. $300 \mathrm{ft}$. f fencing repair that is necessaryon the west side of the fenced area. Also, approx. 10 small signs and / large sign need ho be replaced. Note: Fenced area is not associated with CAS 06-20-02 except for providing a boundary marker for the equipment staging/stornge area. As a result, fencing repair is not required as a post dosure requirement, but may be conducted as a best management practice. Leaving the site at 3:05 PM.

10

15

/s/ Glenn Richardson

$12 / 11 / 07$

Non-RCRA site Inspection of the CA4 005 site in Area 20.

CAL 005

CAS 20-15-01 - A site inspection was performed by the ER

Field Ops. Manager on the afternoon of $12 / 11 / 07$. The site contains $T$-posts with six (6) use restriction signs. The site appeared to be in excellent condition. There was damage to the signage or T-posts.

www.scientificbindery88yrs.com

\begin{tabular}{|l|l|l|l|l|}
\hline SIGNATURE /S/ Glenn Richardson & Work continued to Page \\
\hline DISCLOSED TO AND UNDERSTOOD BY & WITNESS & DATE & DATE \\
\hline
\end{tabular}




\section{ER FIELD OPERATIONS DAILY REPORT}

Wednesday, September 19, 2007

\section{ER FY07 SAFETY STATISTICS}

For FY07, ER has worked 206 consecutive work days (115,190 hours) without a lost time accident.

ER has worked 1,793 consecutive work days (862,210 hours) without a lost time accident. $* * * * *$

\section{CAU 335: Post-Closure Monitoring}

TM: Glenn Richardson

TL: Kevin Olsen

SS: Merl Schwartzwalter

SCOPE OF WORK:

Install posts and use restriction signs at CAU 335

ACCOMPLISHMENTS:

- Installed 16 posts and 8 use restriction signs at CAU 335

STATUS:

CAU 335:

- Install posts and use restriction signs: $100 \%$

ISSUES AND RESOLUTIONS:

None

UPCOMING ACTIVITIES

None

FIELD SCHEDULE:

Field activities are complete 


\section{NSTec}

\section{TRAVELER}
1. Work Package No.: ENV-07-PCM-0142
2. Work Package Type:
(check one)
$1 \square$
$2 \square \quad 3 \otimes$
3. Organization: NSTec, 06-26-07

SECTION I - DESCRIPTION OF WORK (Prepared by work planner)

4. Description of work/activity to be performed:

Various sites around the NTS will require fieldwork including mobilization activities, removing HWAA(s), Decon Pad(s), repairing fencing and signs, and other non-intrusive activities.

5. Area/Building: NTS / Post Closure Sites

6. Requested Start Date: 06-26-07

Specific Location: Various

Forecast End Date: 06-25-08

7. Do other employees in this facility need protection from the hazards of this work? $\square$ Yes $\square$ No If "YES", identify:

8. Permits Required? $\square$ Yes $\square$ No LO/TO Required? $\square$ Yes $\square$ No

9. Permit Types: Excavation / Penetration Permit (as required)

10. Other Requirements: See Work Package

$/ \mathrm{s} / \mathrm{M}$

11. Work Supervisor (Print Name/Sign): Merl Schwartzwalter

Schwartzwalter, $7 \cdot 3.07$ Phone/Pager: $5-6807$

SECTION II - WORK AUTHORIZATION (Completed by facility owner or designee)

12. Point of Contact: (Name/Phone/Pager No.) Brian Konrad / 5-1240 / 4-6084

13. Access requirements have been met? 叉Yes $\square$ N/A

14. Pertinent hazards and controls for this work have been communicated to co-located work groups. 叉Yes $\square$ N/A

15. AUTHORIZATION TO PERMIT WORK - Work is within facility safety envelope and facility configuration determined. Work is authorized for these time periods, facility is ready to accept work, and work is deconflicted.

\begin{tabular}{l|c|c|c|c|c|c|}
\hline Start Date & Start Time & End Date & End Time & Print Facility Owner or Designee/Phone No. & \multicolumn{1}{c}{ Signature } \\
\hline $7-2.07$ & 0700 & $7.2-08$ & 1630 & Teff Smilh $5-3229$ & see original \\
\hline & & & & & & \\
\hline & & & & & & \\
\hline & & & & & & \\
\hline
\end{tabular}

\section{SECTION III - FINAL STATUS/END OF WORK}

17. Work is completed. Area is clean and safe. Post work verification is completed. 


\section{NSTec}

\section{WORK PACKAGE COVER SHEET}

Work Package No.: ENV-07-Post Closure Monitoring-0142

Organization: NSTec Construction, 06-26-07

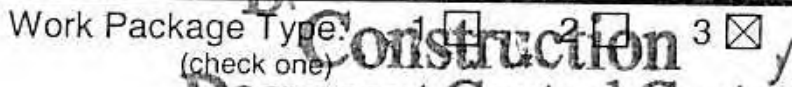
ref Docprnerit Control Centers) SECTION I - DESCRIPTION OF WORK

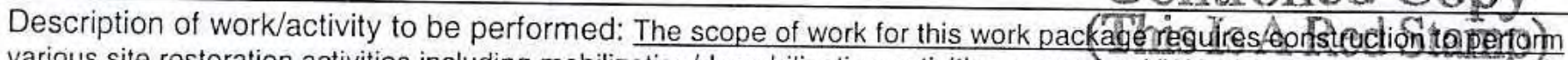
various site restoration activities including mobilization/demobilization activities, removing HWAA(s) and Decon Pad(s)? repairing/modifying/installing fencing and signs, and other non-intrusive activities at various ER. Post Closure Monitoring sites as required.

Area/Building: NTS / Post Closure Sites

Requested Start Date: 06-26-07

Work Package Preparer: John Griffin /s/ JS

Work Supervisor: Merl Schwartzwalter /s/ M Schwartzwalter
Specific Location: Various

Forecast End Date: 06-25-08

Date: $7 \cdot 3 \cdot 07$

\section{SECTION II - APPROVALS}

John Griffin /s/ J Griffin

Work Packáge Preparer

N/A

Safety Professional

Merl Schwartzwalter /s/ M Schwartzwalter

Work Supervispy

Tom Thiele see original

Department Mllmader see original

Facility owner

SECTION III - COMMENTS

Date: $7 \cdot 3-07$

\begin{tabular}{|c|c|c|c|c|}
\hline ? & 7.3 .07 & $H / A$ & & \\
\hline & Date & $\begin{array}{l}\text { Specify Other ER Tech Lead } \\
\text { _ see original }\end{array}$ & - & 7 \\
\hline Schwartzwalter & $\begin{array}{c}\text { Date } \\
7-3-07\end{array}$ & $\begin{array}{l}\text { Spestome ER FOM } \\
\text { see original }\end{array}$ & , & $7 / 3 / 07$ \\
\hline- & $\begin{array}{r}\text { Date } \\
7.3-07 \\
\end{array}$ & $\begin{array}{l}\text { Specifflother RadCon } \\
\text { see original }\end{array}$ & & Date \\
\hline & $\begin{array}{r}\text { Date } \\
7-3-07 \\
\end{array}$ & $\begin{array}{l}\text { Specify Qther EB,Safots } \\
\text { /s/ Glenn Richardson }\end{array}$ & $\cdot$ & $7 / 3 / 07$ \\
\hline & Date & Specify Other ER Task Manager & & Date \\
\hline
\end{tabular}


NSTec

Form

FRM-0185

PRE-TASK HAZARD REVIEW

Part 7: ASSIGNED PERSONNEL SIGN OFF FOR WORK

I HAVE BEEN BRIEFED ON AND UNDERSTAND THE WORK PACKAGE AND THIS PRETASK HAZARD RE
HAVE THE TRAINING QUALF

Employee Signature: see original

Employee Signature: see original

Employee Signature: 'see original

Employee Signature: 'see original

Employee Signature: . see original

Employee Signature: see original

Employee Signature: see original

Employee Signature: see original

Employee Signature: see original

Employee Signature: see original

Employee Signature: see original

Employee Signature: see original

Employee Signature: see original

Employee Signature: see original

Employee Signature: see original

Employee Signature: see original

Employee Signature: „see original

Employee Signature: ${ }^{2}$ see original

Supervisor's Signature: see original

ro

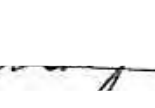

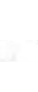
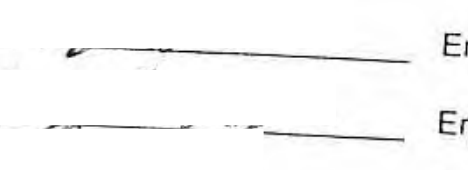

- Employee No: 186270

Employee No:: $\quad 182035$ Date: $7.5-07$

Employee No: /flygel

Employee No.: 185941

Employee No: 1 f6.S06 Date:?-q-e?

Employee No:: 186270 Date: 5 JUL.

- Employee No: 18545

Employee No.:184830

Employee No: $1032 q 2$

Employee No: 185529

- Employee No: 184762

Date: $\sum-5-d 2$

Date: D-5 or

Date: $7-05-67$

Date: $7-05-07$

Date: $\widehat{y} 503$

Date: $7-507$

Date: $7 / 12 / 07$

Employee No.:

Date:

- Employee No: 184762

Date: $7 / 1 / 107$

Employee No::

Employee No.: 184762

Date:

t< Employee No: __ Date:

Date: $7 / 10 / 07$

Date:

7 Employee No:: 184762

Date: $7 / 9 / 07$

Employee No:

- Employee No: 184762

Date:

Date: $7 / 16 / 07$

Comments:

see original

see original see original

see original

see original

see original

see original

see original

see original
Employee No.:

Date:
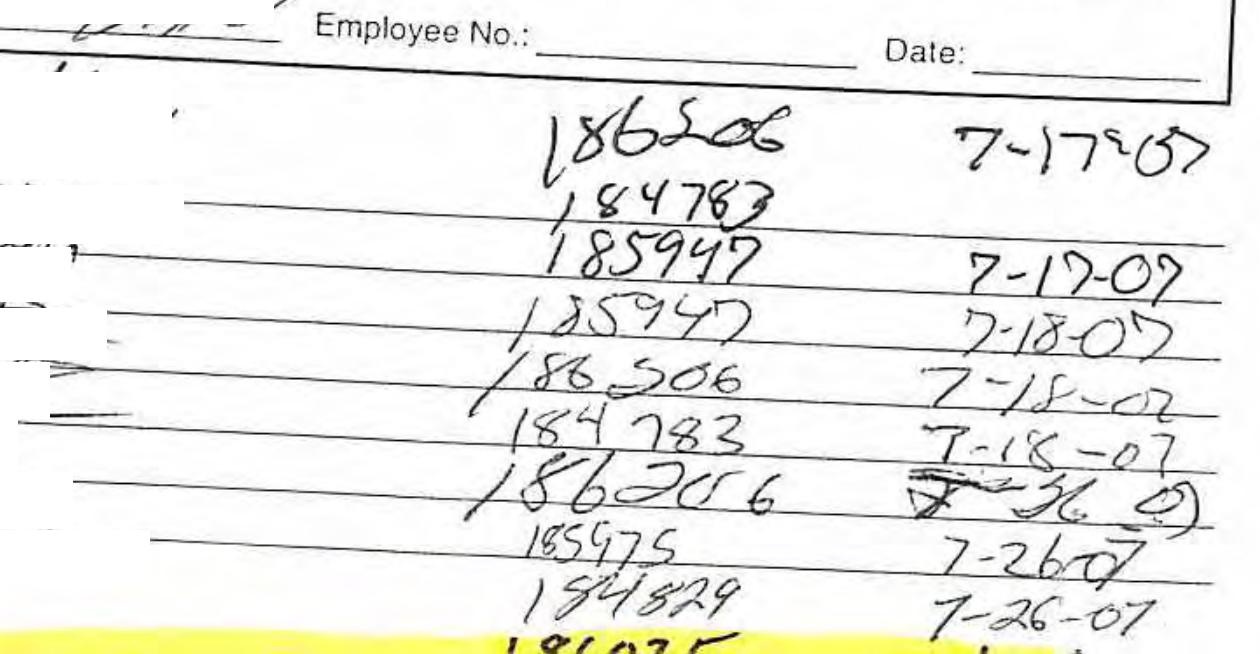
CAU 339: AREA 12 FLEET OPERATIONS STEAM CLEANING EFFLUENT 


\begin{tabular}{|c|c|c|c|}
\hline \multicolumn{4}{|c|}{ POST-CLOSURE INSPECTION CHECKLIST } \\
\hline \multicolumn{4}{|c|}{$\begin{array}{l}\text { CAU 339: AREA 12 FLEET OPERATIONS STEAM CLEANING EFFLUENT } \\
\text { CAS 12-19-01, A12 FLEET OPS STEAM CLEANING EFFLU. }\end{array}$} \\
\hline \multicolumn{2}{|l|}{ Inspection Date and Time: $\quad 12 / 10 / 07 \quad 1: 40 \mathrm{PM}$} & \multicolumn{2}{|c|}{ Reason for Inspection: $A_{n n u_{a}} /$} \\
\hline \multicolumn{2}{|l|}{ Date of Last Post-Closure Inspection: $\quad 1 / 3 / 07$} & \multicolumn{2}{|c|}{ Reason for Last Post-Closure Inspection: Annua/ } \\
\hline \multicolumn{4}{|c|}{ Responsible Entity: NSTec Environmental Restoration, Nevada Test Site, Mercury, Nevada } \\
\hline \multicolumn{4}{|c|}{ Responsible Facility Owner: Jeffrey L. Smith, Deputy Manager, Environmental Restoration } \\
\hline \multicolumn{2}{|l|}{ Chief Inspector: Gleun Richardson } & \multicolumn{2}{|c|}{ Title: Task Manager } \\
\hline \multicolumn{2}{|l|}{ Assistant Inspector: Brian Konrad } & \multicolumn{2}{|r|}{ Title: ER Field Operations Manager } \\
\hline \multicolumn{4}{|c|}{$\begin{array}{l}\text { A. GENERAL INSTRUCTIONS } \\
\text { 1. All checklist items must be completed and detailed comments made to document the results of the site inspection. The completed checklist is } \\
\text { part of the field record of the inspection. Additional pages should be used as necessary to ensure that a complete record is made. Attach the } \\
\text { additional pages and number all pages upon completion of the inspection. } \\
\text { 2. Any checklist line item marked by an inspector in a SHADED BOX must be fully explained or an appropriate reference to previous reports } \\
\text { provided. The purpose of this requirement is to provide a written explanation of inspector observations and the inspector's rationale for } \\
\text { conclusions and recommnendations. Explanations are to be placed on additional attachments and cross-referenced appropriately. } \\
\text { Explanations, in addition to narrative, will take the form of sketches, measurements, and annotated site maps. } \\
\text { 3. The site inspection is a walking inspection of the entire site including the perimeter and sufficient transects to be able to inspect the entire } \\
\text { surface and all features specifically described in this checklist. } \\
\text { 4. Field notes taken to assist in completion of this checklist will become part of the inspection record. No form is specified for field notes; } \\
\text { however, they must be legible and in sufficient detail to enable review by succeeding inspectors and the responsible agency. } \\
\text { 5. This unit will be inspected annually with formal reporting to the Nevada Division of Environmental Protection to be done annually. The } \\
\text { annual letter report will include a summary with this inspection checklist attached. }\end{array}$} \\
\hline B. PREPARATION (To be competed prior to site visit) & YES & NO & EXPLANATION (required if shaded box is checked) \\
\hline \multicolumn{4}{|l|}{ 1. Has the Post-Closure Plan been reviewed? } \\
\hline \\
\hline \multicolumn{4}{|l|}{ 3. Were anomalies or trends detected on previous inspections? } \\
\hline & & $\begin{array}{l}\text { As a result of the last inspection, danaged } \\
\text { T-posts were replaced and wire rope restrueng in dama }\end{array}$ \\
\hline \multicolumn{4}{|c|}{ C. SITE INSPECTION PREPARATION } \\
\hline \multicolumn{4}{|c|}{$\begin{array}{l}\text { Assemble the following, as needed, to conduct inspections: } \\
\text { a. Radio, pager, etc. } \\
\text { b. Previous letter report, inspection checklists, repair records, and as-built plans } \\
\text { c. Other miscellaneous support equipment } \\
\end{array}$} \\
\hline \multicolumn{4}{|l|}{ D. SITE INSPECTION } \\
\hline 1. Site markers: & YES & NO & EXPLANATION (required if shaded box is checked) \\
\hline \multicolumn{4}{|l|}{ a. Is there damage to the fence? } \\
\hline \multicolumn{4}{|l|}{$\begin{array}{l}\text { b. Have any posts been damaged or their anchoring } \\
\text { weakened? }\end{array}$} \\
\hline \multicolumn{4}{|l|}{ c. Are any of the use restriction signs damaged or missing? } \\
\hline \multicolumn{4}{|l|}{ d. Are all use restriction signs legible? } \\
\hline e. How many signs need to be replaced? & & & \\
\hline
\end{tabular}




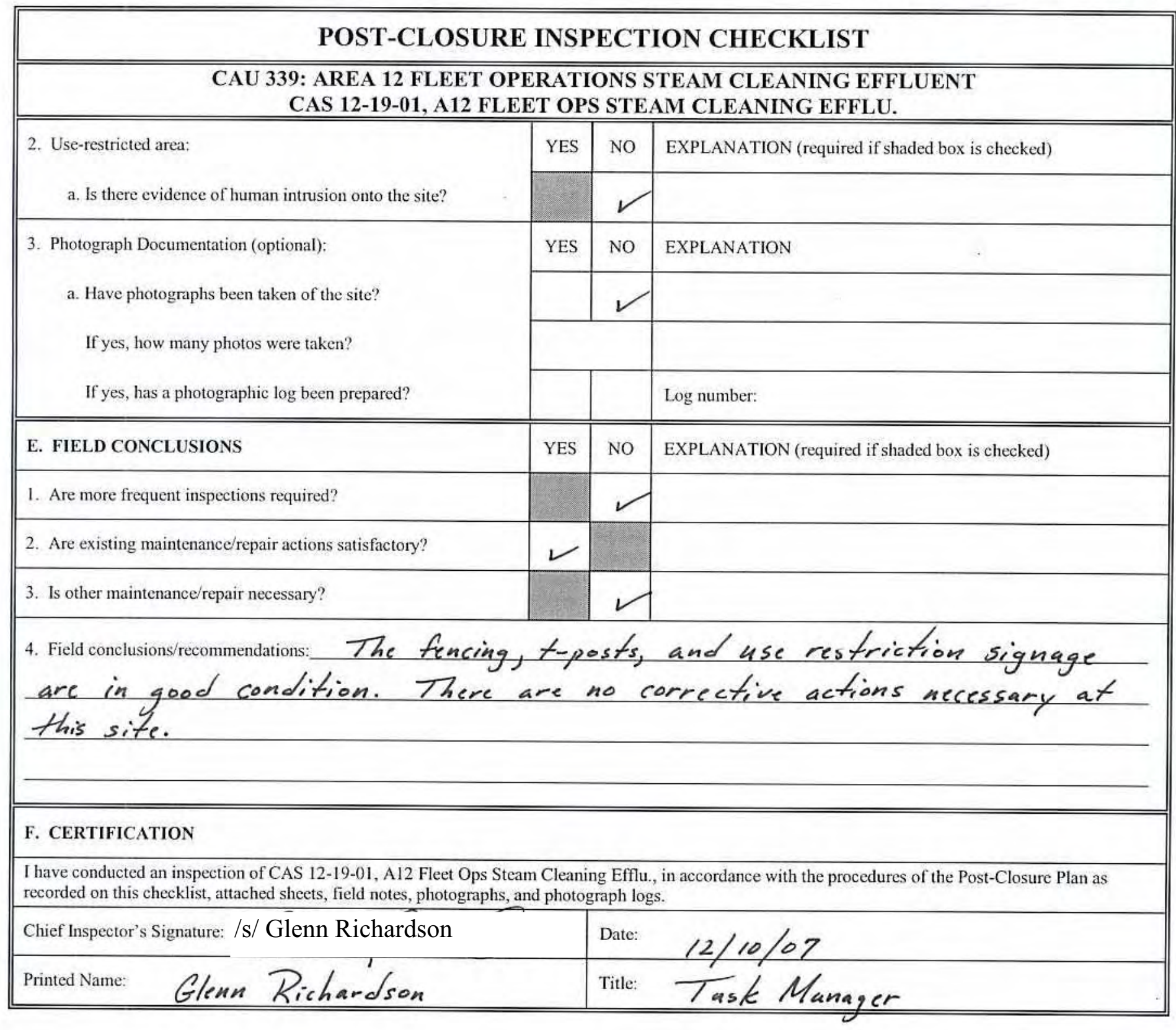


CAU 342: AREA 23 MERCURY FIRE TRAINING PIT 


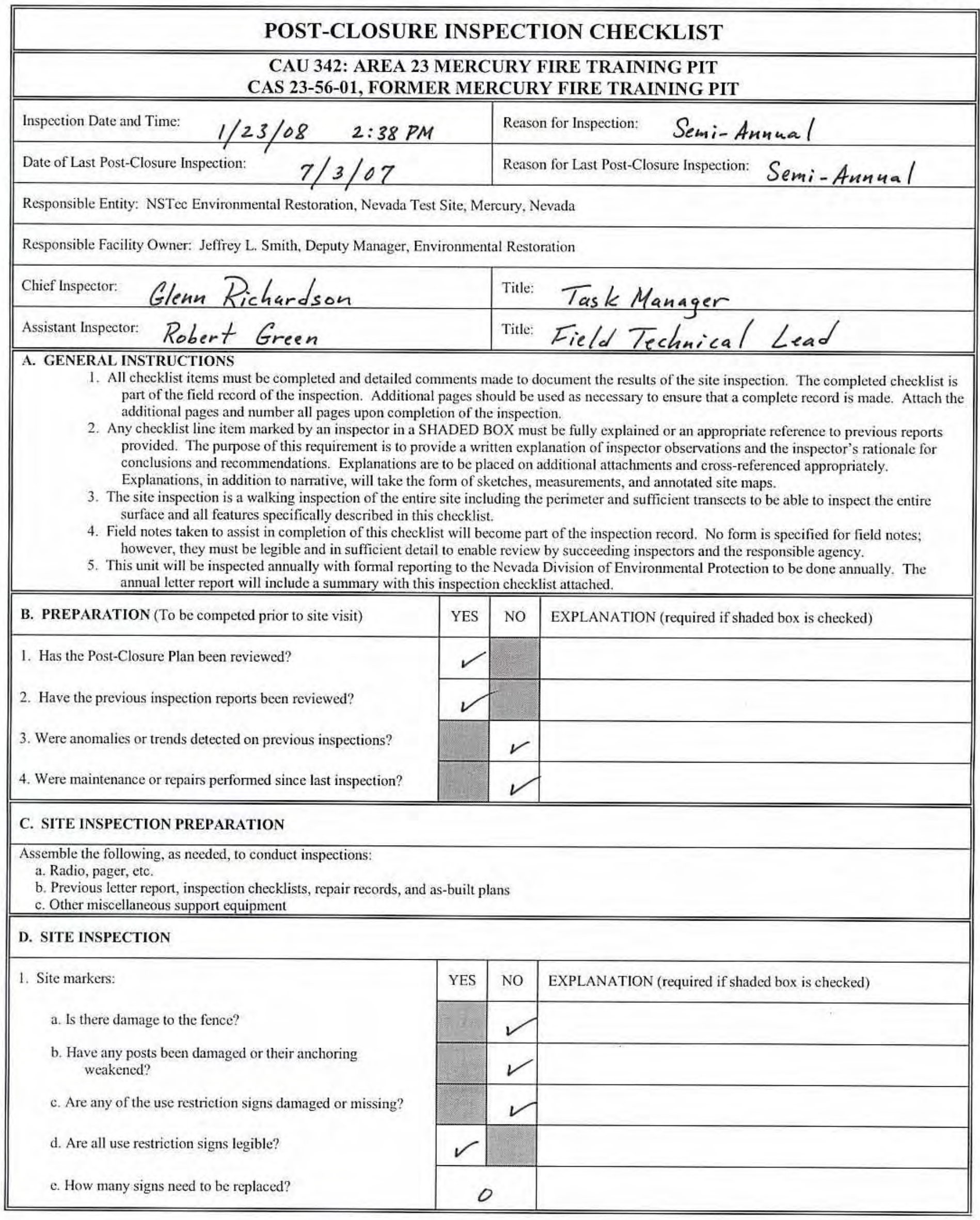




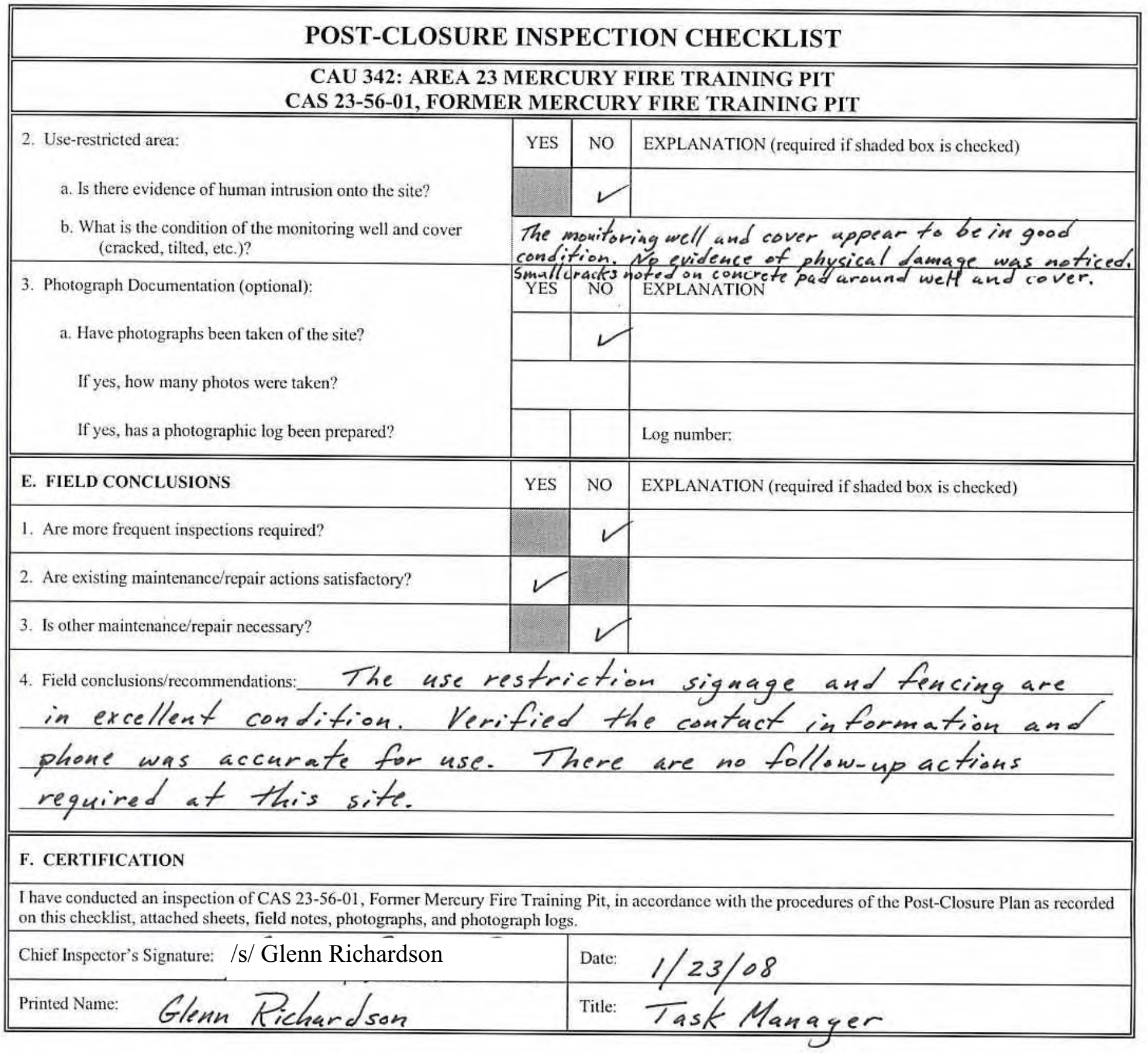




\begin{tabular}{|c|c|c|c|}
\hline \multicolumn{4}{|c|}{ POST-CLOSURE INSPECTION CHECKLIST } \\
\hline \multicolumn{4}{|c|}{$\begin{array}{l}\text { CAU 342: AREA } 23 \text { MERCURY FIRE TRAINING PIT } \\
\text { CAS 23-56-01, FORMER MERCURY FIRE TRAINING PIT }\end{array}$} \\
\hline \multicolumn{2}{|c|}{ Inspection Date and Time: $7 / 3 / 07 \quad 1330$} & \multicolumn{2}{|c|}{ Reason for Inspection: Semi-annua/ } \\
\hline \multicolumn{2}{|l|}{ Date of Last Post-Closure Inspection: $12 / 28 / 06$} & \multicolumn{2}{|c|}{ Reason for Last Post-Closure Inspection: Semi-annual } \\
\hline \multicolumn{4}{|c|}{ Responsible Entity: NSTec Environmental Restoration, Nevada Test Site, Mercury, Nevada } \\
\hline \multicolumn{4}{|c|}{ Responsible Facility Owner: Jeffrey L. Smith, Deputy Manager, Environmental Restoration } \\
\hline \multicolumn{2}{|l|}{ Chief inspector: Mik FOYP } & \multicolumn{2}{|c|}{ Title: $F$} \\
\hline \multicolumn{2}{|l|}{ Assistant Inspector: Glena Rechradson } & \multicolumn{2}{|c|}{ Title: Thste Uhreagen } \\
\hline \multicolumn{4}{|c|}{$\begin{array}{l}\text { A. GENERAL INSTRUCTIONS } \\
\text { 1. All checklist items must be completed and detailed comments made to document the results of the site inspection. The completed checklist is } \\
\text { part of the field record of the inspection. Additional pages should be used as necessary to ensure that a complete record is made. Attach th } \\
\text { additional pages and number all pages upon completion of the inspection. } \\
\text { 2. Any checklist line item marked by an inspector in a SHADED BOX must be fully explained or an appropriate reference to previous reports } \\
\text { provided. The purpose of this requirement is to provide a written explanation of inspector observations and the inspector's rationale for } \\
\text { conclusions and recommendations. Explanations are to be placed on additional attachments and cross-referenced appropriately. } \\
\text { Explanations, in addition to narrative, will take the form of sketches, measurements, and annotated site maps. } \\
\text { 3. The site inspection is a walking inspection of the entire site including the perimeter and sufficient transects to be able to inspect the entire } \\
\text { surface and all features specifically described in this checklist. } \\
\text { 4. Field notes taken to assist in completion of this checklist will become part of the inspection record. No form is specified for field notes; } \\
\text { however, they must be legible and in sufficient detail to enable review by succeeding inspectors and the responsible agency. } \\
\text { 5. This unit will be inspected annually with formal reporting to the Nevada Division of Environmental Protection to be done annually. The } \\
\text { annual letter report will include a summary with this inspection checklist attached. }\end{array}$} \\
\hline B. PREPARATION (To be competed prior to site visit) & YES & NO & EXPLANATION (required if shaded box is checked) \\
\hline \multicolumn{4}{|l|}{ 1. Has the Post-Closure Plan been reviewed? } \\
\hline \multirow{2}{*}{$\begin{array}{l}\text { 2. Have the previous inspection reports been reviewed? } \\
\text { 3. Were anomalies or trends detected on previous inspections? }\end{array}$} & $\checkmark$ & & \\
\hline & & $\checkmark$ & \\
\hline \multicolumn{2}{|l|}{ 4. Were maintenance or repairs performed since last inspection? } & $V$ & \\
\hline \multicolumn{4}{|l|}{ C. SITE INSPECTION PREPARATION } \\
\hline \multicolumn{4}{|c|}{$\begin{array}{l}\text { Assemble the following, as needed, to conduct inspections: } \\
\text { a. Radio, pager, etc. } \\
\text { b. Previous letter report, inspection checklists, repair records, and as-built plans } \\
\text { c. Other miscellaneous support equipment }\end{array}$} \\
\hline \multicolumn{4}{|l|}{ D. SITE INSPECTION } \\
\hline \multirow{2}{*}{$\begin{array}{l}\text { 1. Site markers: } \\
\text { a. Is there damage to the fence? }\end{array}$} & YES & NO & EXPLANATION (required if shaded box is checked) \\
\hline & & 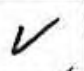 & \\
\hline \multicolumn{4}{|l|}{$\begin{array}{l}\text { b. Have any posts been damaged or their anchoring } \\
\text { weakened? }\end{array}$} \\
\hline \multicolumn{4}{|l|}{ c. Are any of the use restriction signs damaged or missing? } \\
\hline d. Are all use restriction signs legible? & $V$ & & \\
\hline e. How many signs need to be replaced? & & & \\
\hline
\end{tabular}


Inspection Requirement: Biannual (twice per year)

POST-CLOSURE INSPECTION CHECKLIST

CAU 342: AREA 23 MERCURY FIRE TRAINING PIT CAS 23-56-01, FORMER MERCURY FIRE TRAINING PIT

2. Use-restricted area:

a. Is there evidence of human intrusion onto the site?

b. What is the condition of the monitoring well and cover (cracked, tilted, etc.)?

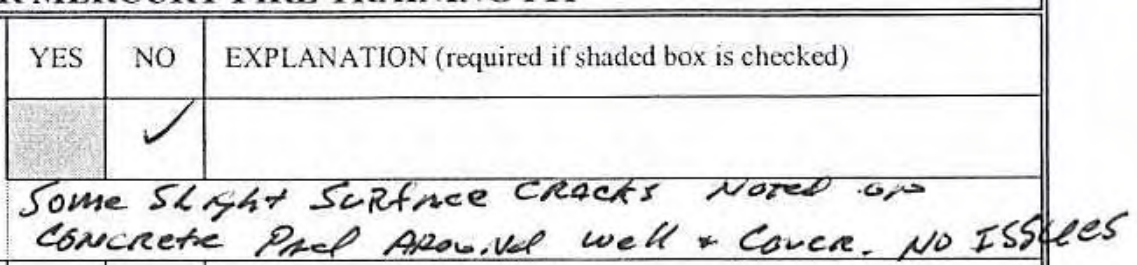

3. Photograph Documentation (optional):

a. Have photographs been taken of the site?

If yes, how many photos were taken?

If yes, has a photographic log been prepared?

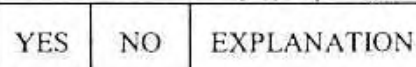

E. FIELD CONCLUSIONS

YES

1. Are more frequent inspections required?

2. Are existing maintenance/repair actions satisfactory?

3. Is other maintenance/repair necessary?

4. Field conclusionssreconmendations: The Fence, Cigar of Gate and all General Sate area were found to ie in gad Condition.

F. CERTIFICATION

I have conducted an inspection of CAS 23-56-01, Former Mercury Fire Training Pit, in accordance with the procedures of the Post-Closure Plan as recorded on this checklist, attached sheets, field notes, photographs, and photograph logs.

\begin{tabular}{|l|l|}
\hline Chief Inspector's signatures $/ \mathrm{s} /$ Mike Floyd & Date: $\$ / 3 / 67$ \\
\hline Printed Name: M. he Flo sp & Title: FTC \\
\hline
\end{tabular}


CAU 357: MUD PITS AND WASTE DUMP 


\section{POST-CLOSURE INSPECTION CHECKLIST}

\section{CAU 357: MUD PITS AND WASTE DUMPS - CAS 04-26-03, LEAD BRICKS}

\begin{tabular}{||l|l|}
\hline \hline Inspection Date and Time: $1 / 23 / 08 \quad 9: 58 \mathrm{AM}$ & Reason for Inspection: Annual \\
\hline Date of Last Post-Closure Inspection: $1 / 4 / 07$ & Reason for Last Post-Closure Inspection: Annua/ \\
\hline
\end{tabular}

Responsible Entity: NSTec Environmental Restoration, Nevada Test Site, Mercury, Nevada

Responsible Facility Owner: Jeffrey L. Smith, Deputy Manager, Environmental Restoration

\begin{tabular}{l|l}
\hline Chief inspector: Geun Kichardson & Title: Task Manager \\
\hline Assistant Inspector: Robert Green & Title: Field Technical Lead \\
\hline
\end{tabular}

A. GENERAL INSTRUCTIONS

1. All checklist items must be completed and detailed comments made to document the results of the site inspection. The completed checklist is part of the field record of the inspection. Additional pages should be used as necessary to ensure that a complete record is made. Attach the additional pages and number all pages upon completion of the inspection.

2. Any checklist line item marked by an inspector in a SHADED BOX must be fully explained or an appropriate reference to previous reports provided. The purpose of this requirement is to provide a written explanation of inspector observations and the inspector's rationale for conclusions and recommendations. Explanations are to be placed on additional attachments and cross-referenced appropriately. Explanations, in addition to narrative, will take the form of sketches, measurements, and annotated site maps.

3. The site inspection is a walking inspection of the entire site including the perimeter and sufficient transects to be able to inspect the entire surface and all features specifically described in this checklist.

4. Field notes taken to assist in completion of this checklist will become part of the inspection record. No form is specified for field notes; however, they must be legible and in sufficient detail to enable review by succeeding inspectors and the responsible agency.

5. This unit will be inspected annually with formal reporting to the Nevada Division of Environmental Protection to be done annually. The annual letter report will include a summary with this inspection checklist attached.

\begin{tabular}{|c|c|c|c|}
\hline B. PREPARATION (To be competed prior to site visit) & YES & NO & EXPLANATION (required if shaded box is checked) \\
\hline 1. Has the Post-Closure Plan been reviewed? & & & \\
\hline 2. Have the previous inspection reports been reviewed? & & & \\
\hline 3. Were anomalies or trends detected on previous inspections? & & & \\
\hline 4. Were maintenance or repairs performed since last inspection? & & & \\
\hline
\end{tabular}

\section{SITE INSPECTION PREPARATION}

Assemble the following, as needed, to conduct inspections:

a. Radio, pager, etc.

b. Previous letter report, inspection checklists, repair records, and as-built plans

c. Other miscellaneous support equipment

\section{SITE INSPECTION}

1. Site markers:

a. Have any posts been damaged or their anchoring weakened?

b. Are any of the use restriction signs damaged or missing?

c. Are all use restriction signs legible?

d. How many signs need to be replaced?

2. Use-restricted area:

a. Is there evidence of human intrusion onto the site?

\begin{tabular}{|l|l|l||}
\hline YES & NO & EXPLANATION (required if shaded box is checked) \\
\hline & & \\
\hline & & \\
\hline & 0 & \\
\hline YES & NO & EXPLANATION (required if shaded box is checked) \\
\hline & & \\
\hline
\end{tabular}


POST-CLOSURE INSPECTION CHECKLIST

\section{CAU 357: MUD PITS AND WASTE DUMPS - CAS 04-26-03, LEAD BRICKS}

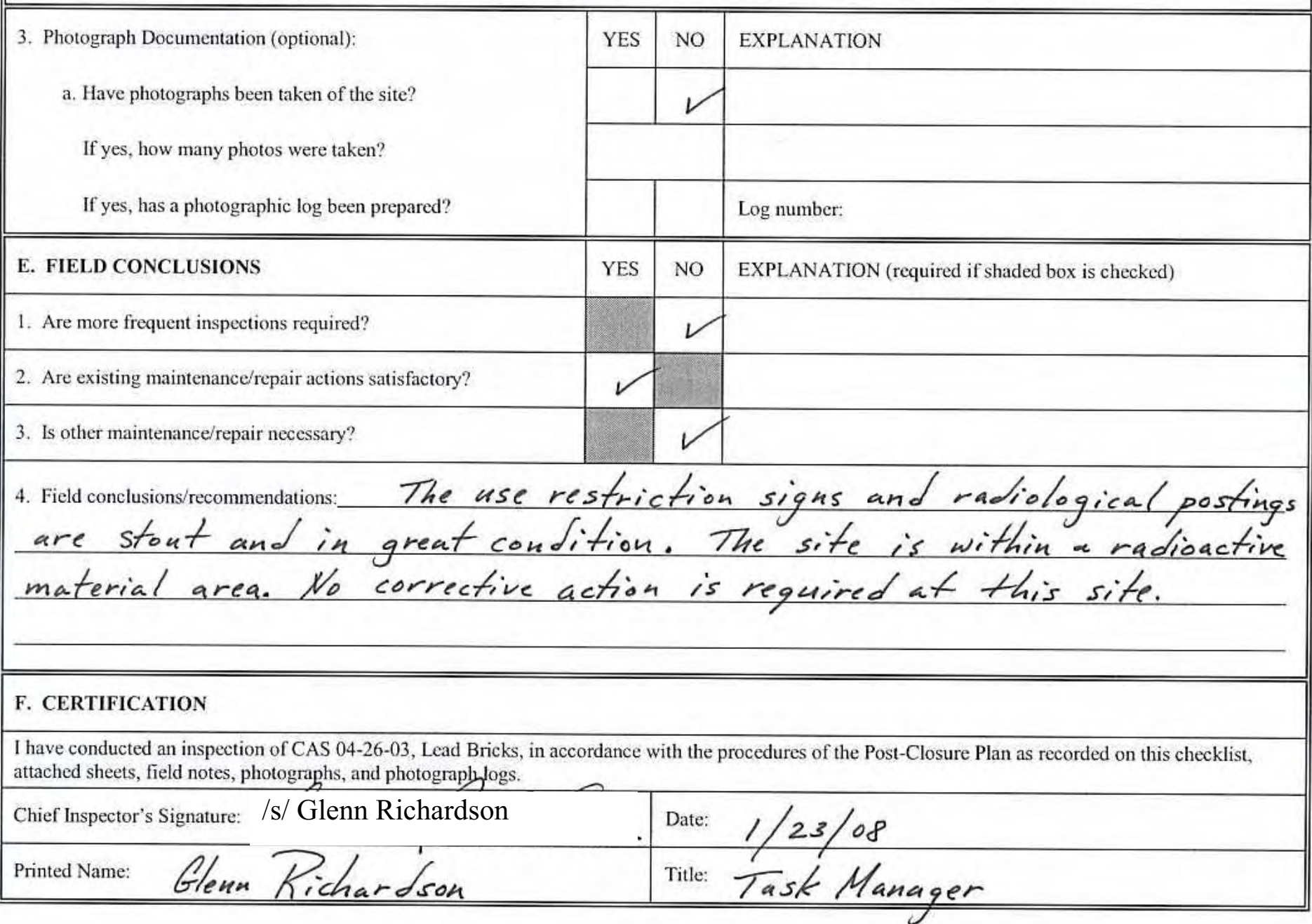




\section{POST-CLOSURE INSPECTION CHECKLIST}

\section{CAU 357: MUD PITS AND WASTE DUMPS - CAS 10-09-06, MUD PIT; STAINS; MATERIAL}

\begin{tabular}{||l|l|}
\hline \hline Inspection Date and Time: $1 / 16 / 08 \quad 3: 55 \mathrm{PM}$ & Reason for Inspection: Annual \\
\hline Date of Last Post-Closure Inspection: $1 / 4 / 07$ & Reason for Last Post-Closure Inspection: Annual \\
\hline
\end{tabular}

Responsible Entity: NSTec Environmental Restoration, Nevada Test Site, Mercury, Nevada

Responsible Facility Owner: Jeffrey L. Smith, Deputy Manager, Environmental Restoration

\begin{tabular}{l|l}
\hline Chief Inspector: Gleun Richardson & Title: Task Manager \\
\hline Assistant Inspector: Robert Green & Title: Field Technical Lead
\end{tabular}

A. GENERAL INSTRUCTIONS

1. All checklist items must be completed and detailed comments made to document the results of the site inspection. The completed checklist is part of the field record of the inspection. Additional pages should be used as necessary to ensure that a complete record is made. Attach the additional pages and number all pages upon completion of the inspection.

2. Any checklist line item marked by an inspector in a SHADED BOX must be fully explained or an appropriate reference to previous reports provided. The purpose of this requirement is to provide a written explanation of inspector observations and the inspector's rationale for conclusions and recommendations. Explanations are to be placed on additional attachments and cross-referenced appropriately. Explanations, in addition to narrative, will take the form of sketches, measurements, and annotated site maps.

3. The site inspection is a walking inspection of the entire site including the perimeter and sufficient transects to be able to inspect the entire surface and all features specifically described in this checklist.

4. Field notes taken to assist in completion of this checklist will become part of the inspection record. No form is specified for field notes; however, they must be legible and in sufficient detail to enable review by succeeding inspectors and the responsible agency.

5. This unit will be inspected annually with formal reporting to the Nevada Division of Environmental Protection to be done annually. The annual letter report will include a summary with this inspection checklist attached.

B. PREPARATION (To be competed prior to site visit)

1. Has the Post-Closure Plan been reviewed?

2. Have the previous inspection reports been reviewed?

3. Were anomalies or trends detected on previous inspections?

4. Were maintenance or repairs performed since last inspection?

\begin{tabular}{|l|l|l||}
\hline YES & NO & EXPLANATION (required if shaded box is checked) \\
\hline & & \\
\hline
\end{tabular}

\section{SITE INSPECTION PREPARATION}

Assemble the following, as needed, to conduct inspections:

a. Radio, pager, etc.

b. Previous letter report, inspection checklists, repair records, and as-built plans

c. Other miscellaneous support equipment

\section{SITE INSPECTION}

1. Site markers:

a. Have any posts been damaged or their anchoring weakened?

b. Are any of the use restriction signs damaged or missing?

c. Are all use restriction signs legible?

d. How many signs need to be replaced?

2. Use-restricted area:

a. Is there evidence of human intrusion onto the site?

\begin{tabular}{|c|c|l||}
\hline YES & NO & EXPLANATION (required if shaded box is checked) \\
\hline & & \\
\hline & & \\
\hline & & \\
\hline YES & NO & EXPLANATION (required if shaded box is checked) \\
\hline & \multicolumn{1}{|l|}{} \\
\hline
\end{tabular}




\section{POST-CLOSURE INSPECTION CHECKLIST}

\section{CAU 357: MUD PITS AND WASTE DUMPS - CAS 10-09-06, MUD PIT; STAINS; MATERIAL}

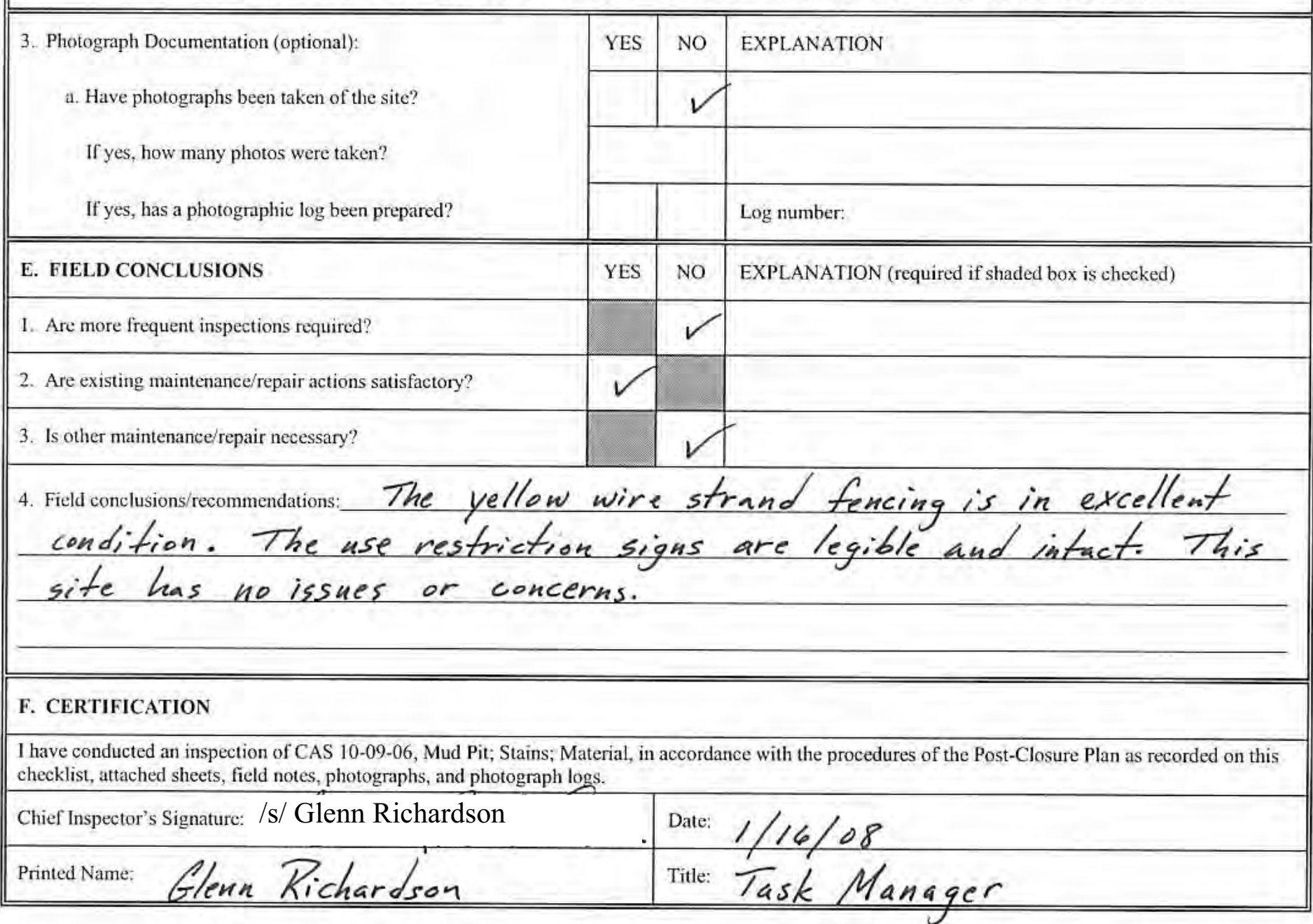




\section{POST-CLOSURE INSPECTION CHECKLIST}

\section{CAU 357: MUD PITS AND WASTE DUMPS - CAS 25-15-01, WASTE DUMP}

\begin{tabular}{|l|l|}
\hline \hline Inspection Date and Time: $12 / 13 / 07 / 630$ & Reason for Inspection: \\
\hline Date of Last Post-Closure inspection: $12 / 19 / 06$ & Reason for Last Post-Closure Inspection: \\
\hline
\end{tabular}

Responsible Entity: NSTec Environmental Restoration, Nevada Test Site, Mercury, Nevada

Responsible Facility Owner: Jeffrey L. Smith, Deputy Manager, Environmental Restoration

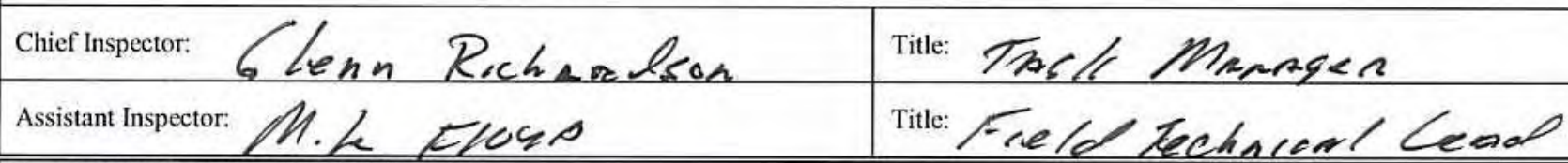

A. GENERAL INSTRUCTIONS

1. All checklist items must be completed and detailed comments made to document the results of the site inspection. The completed checklist is part of the field record of the inspection. Additional pages should be used as necessary to ensure that a complete record is made. Attach the additional pages and number all pages upon completion of the inspection.

2. Any checklist line item marked by an inspector in a SHADED BOX must be fully explained or an appropriate reference to previous reports provided. The purpose of this requirement is to provide a written explanation of inspector observations and the inspector's rationale for conclusions and recommendations. Explanations are to be placed on additional attachments and cross-referenced appropriately. Explanations, in addition to narrative, will take the form of sketches, measurements, and annotated site maps.

3. The site inspection is a walking inspection of the entire site including the perimeter and sufficient transects to be able to inspect the entire surface and all features specifically described in this checklist.

4. Field notes taken to assist in completion of this checklist will become part of the inspection record. No form is specified for field notes; however, they must be legible and in sufficient detail to enable review by succeeding inspectors and the responsible agency.

5. This unit will be inspected annually with formal reporting to the Nevada Division of Environmental Protection to be done annually. The annual letter report will include a summary with this inspection checklist attached.

B. PREPARATION (To be competed prior to site visit)

1. Has the Post-Closure Plan been reviewed?

2. Have the previous inspection reports been reviewed?

3. Were anomalies or trends detected on previous inspections?

4. Were maintenance or repairs performed since last inspection?

\section{SITE INSPECTION PREPARATION}

Assemble the following, as needed, to conduct inspections:

a. Radio, pager, etc.

b. Previous letter report, inspection checklists, repair records, and as-built plans

c. Other miscellancous support equipment

\section{SITE INSPECTION}

1. Site markers:

a. Are any of the use restriction signs damaged or missing?

b. Are all use restriction signs legible?

c. How many signs need to be replaced?

2. Use-restricted area:

a. Is there evidence of human intrusion onto the site?

\begin{tabular}{|l|l|l|}
\hline YES & NO & EXPLANATION (required if shaded box is checked) \\
\hline$X$ & & \\
\hline$X$ & & \\
\hline & $X$ & \\
\hline & $X$ & \\
\hline
\end{tabular}




\section{POST-CLOSURE INSPECTION CHECKLIST}

\section{CAU 357: MUD PITS AND WASTE DUMPS - CAS 25-15-01, WASTE DUMP}

3. Photograph Documentation (optional):

a. Have photographs been taken of the site?

If yes, how many photos were taken?

If yes, has a photographic $\log$ been prepared?

\begin{tabular}{|c|c|c|}
\hline YES & NO & EXPLANATION \\
\hline & $\chi$ & \\
\hline & & Log number: \\
\hline YES & NO & EXPLANATION (required if shaded box is checked) \\
\hline & X & \\
\hline$x$ & & \\
\hline & $x$ & \\
\hline+ & 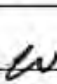 & sund to Be in good \\
\hline
\end{tabular}

\begin{tabular}{|c|c|c|c|}
\hline E. FIELD CONCLUSIONS & YES & NO & EXPLANATION (required if shaded box is checked) \\
\hline 1. Are more frequent inspections required? & & X & \\
\hline 2. Are existing maintenance/repair actions satisfactory? & $x$ & & \\
\hline 3. Is other maintenance/repair necessary? & & X & \\
\hline
\end{tabular}

\section{F. CERTIFICATION}

I have conducted an inspection of CAS 25-15-01, Waste Dump, in accondance with the procedures of the Post-Closure Plan as recorded on this checklist, attached sheets, field notes, photographs, and photograph logs.

Chief Inspector's Signature: /s/ Glenn Richardson Printed Name: Hite Gleme Mrehapdsos \begin{tabular}{l} 
Date: $12 / 1 / 3 / 0 /$ \\
\hline Title: Ths/c Mavplex
\end{tabular} 
CAU 383: AREA 12 E-TUNNEL SITES 


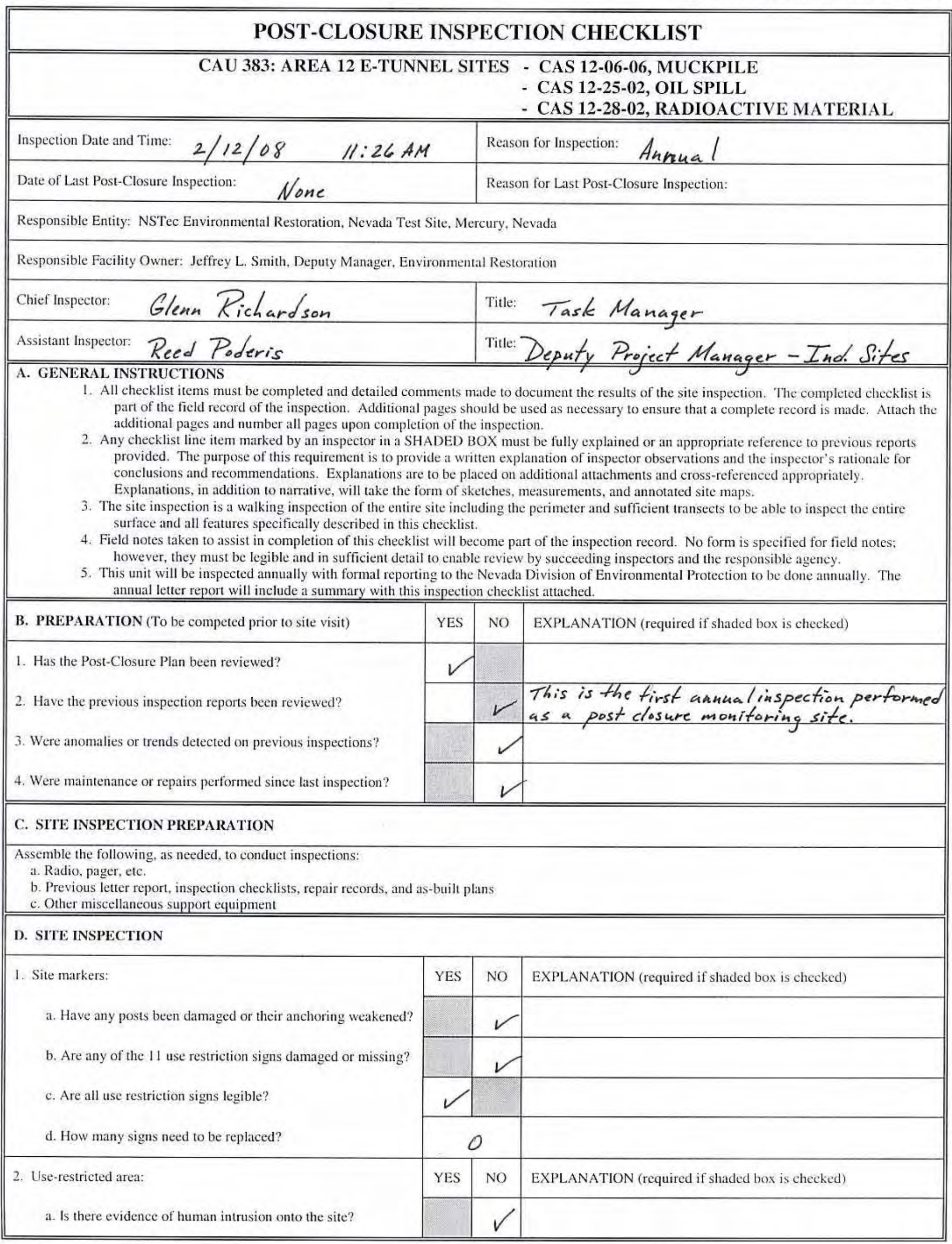




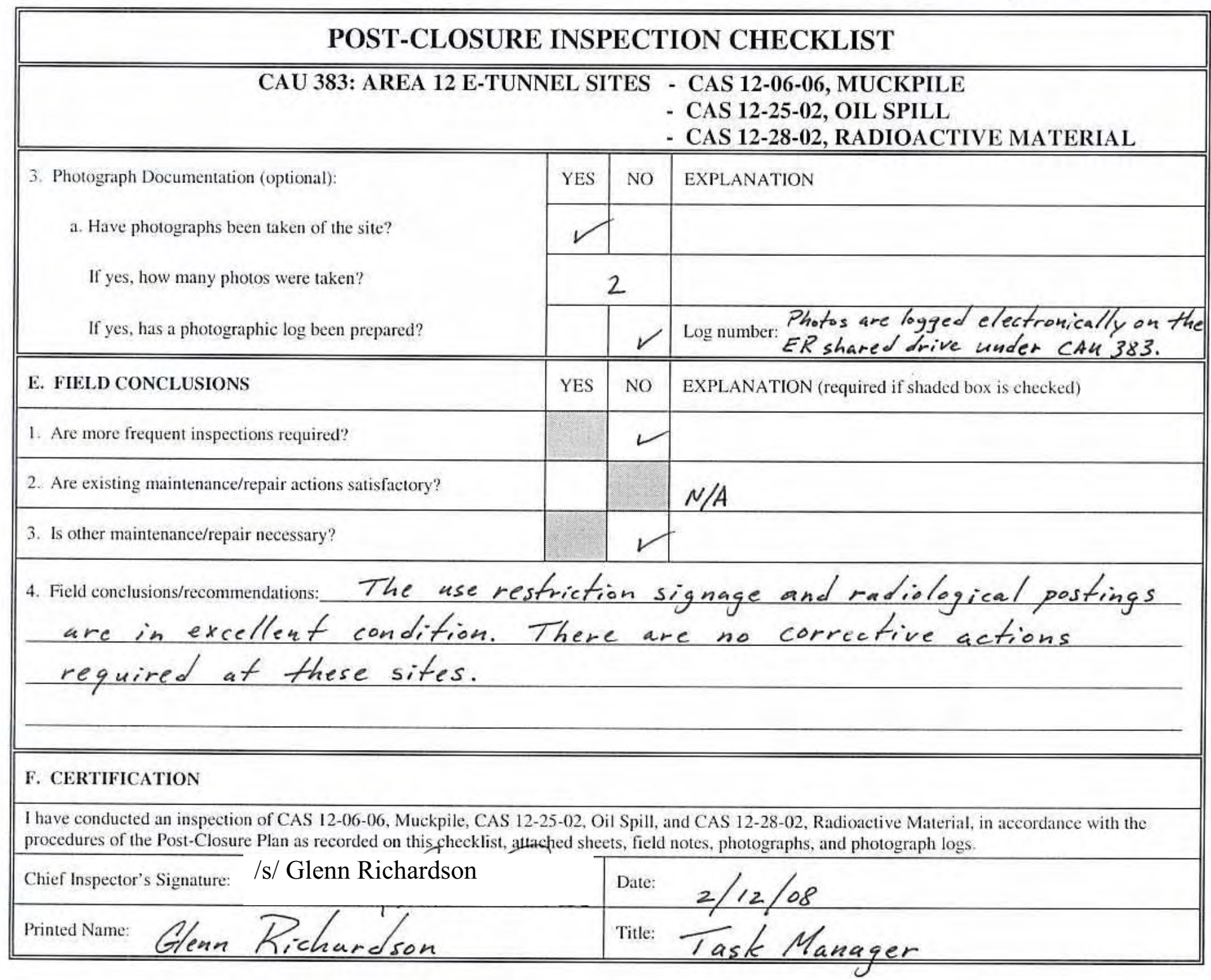


CAU 528: POLYCHLORINATED BIPHENYLS CONTAMINATION 
POST-CLOSURE INSPECTION CHECKLIST

CAU 528: POLYCHLORINATED BIPHENYLS CONTAMINATION

CAS 25-27-03, POLYCHLORINATED BIPHENYLS SURFACE CONTAMINATION

\begin{tabular}{|l|l|}
\hline \hline Inspection Date and Time: $12 / 3 / 07 \quad 10,50$ & Reason for Inspection: PNMUG/ \\
\hline Date of Last Post-Closure Inspection: None & Reason for Last Post-Closure Inspection: AMNUA/ \\
\hline
\end{tabular}

Responsible Entity: NSTec Environmental Restoration, Nevada Test Site, Mercury, Nevada

Responsible Facility Owner: Jeffrey L. Smith, Deputy Manager, Environmental Restoration

Chief Inspector: G/enn R/chapdras

Assistant Inspector:

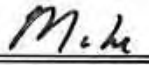

F1040
Title: TASlC MANRERE

Title: Field Techareal LeAch

A. GENERAL INSTRUCTIONS

1. All checklist items must be completed and detailed comments made to document the results of the site inspection. The completed checklist is part of the field record of the inspection. Additional pages should be used as necessary to ensure that a complete record is made. Attach the additional pages and number all pages upon completion of the inspection.

2. Any checklist line item marked by an inspector in a SHADED BOX must be fully explained or an appropriate reference to previous reports provided. The purpose of this requirement is to provide a written explanation of inspector observations and the inspector's rationale for conclusions and recommendations. Explanations are to be placed on additional attachments and cross-referenced appropriately. Explanations, in addition to narrative, will take the form of sketches, measurements, and annotated site maps.

3. The site inspection is a walking inspection of the entire site including the perimeter and sufficient transects to be able to inspect the entire surface and all features specifically described in this checklist.

4. Field notes taken to assist in completion of this checklist will become part of the inspection record. No form is specified for field notes; however, they must be legible and in sufficient detail to enable review by succeeding inspectors and the responsible agency.

5. This unit will be inspected annually with formal reporting to the Nevada Division of Environmental Protection to be done annually. The annual letter report will include a summary with this inspection checklist attached.

B. PREPARATION (To be competed prior to site visit)

1. Has the Post-Closure Plan been reviewed?

2. Have the previous inspection reports been reviewed?

3. Were anomalies or trends detected on previous inspections?

4. Were maintenance or repairs performed since last inspection?

a. If yes, obtain a copy of maintenance records and attach to checklist.

\begin{tabular}{|c|c|c||}
\hline YES & NO & \multicolumn{2}{||}{ EXPLANATION (required if shaded box is checked) } \\
\hline X & & \\
\hline & & \\
\hline & $X$ & \\
\hline & $X$ & \\
\hline & & NA \\
& & \\
\hline
\end{tabular}

\section{SITE INSPECTION PREPARATION}

Assemble the following, as needed, to conduct inspections:

a. Radio, pager, etc.

b. Previous letter report, inspection checklists, repair records, and as-built plans

c. Other miscellaneous support equipment

\section{SITE INSPECTION}

1. Site markers:

a. Have any posts been damaged or their anchoring weakened?

b. Are any of the use restriction signs damaged or missing?

c. Are all use restriction signs legible?

d. How many signs need to be replaced?

\begin{tabular}{|c|c|l|}
\hline YES & NO & EXPLANATION (required if shaded box is checked) \\
\hline & $X$ & \\
\hline & $X$ & \\
\hline$X$ & & \\
\hline
\end{tabular}




\begin{tabular}{|c|c|c|c|}
\hline \multicolumn{4}{|c|}{ POST-CLOSURE INSPECTION CHECKLIST } \\
\hline \multicolumn{4}{|c|}{$\begin{array}{l}\text { CAU 528: POLYCHLORINATED BIPHENYLS CONTAMINATION } \\
\text { CAS 25-27-03, POLYCHLORINATED BIPHENYLS SURFACE CONTAMINATION } \\
\end{array}$} \\
\hline \multirow{2}{*}{$\begin{array}{l}\text { 2. Use-restricted area: } \\
\text { a. Is there evidence of human intrusion onto the site? }\end{array}$} & YES & NO & EXPLANATION (required if shaded box is checked) \\
\hline & & x & \\
\hline \multirow{4}{*}{$\begin{array}{l}\text { 3. Photograph Documentation (optional): } \\
\text { a. Have photographs been taken of the site? } \\
\text { If yes, how many photos were taken? } \\
\text { If yes, has a photographic log been prepared? }\end{array}$} & YES & NO & EXPLANATION \\
\hline & & & \\
\hline & & & \\
\hline & & & Log number: \\
\hline E. FIELD CONCLUSIONS & YES & NO & EXPLANATION (required if shaded box is checked) \\
\hline \multicolumn{4}{|l|}{ 1. Are more frequent inspections required? } \\
\hline 2. Are existing maintenance/repair actions satisfactory? & & & YES \\
\hline 3. Is other maintenance/repair necessary? & $x$ & एक्ष & See feold Reeommendartones \\
\hline \multicolumn{4}{|c|}{ 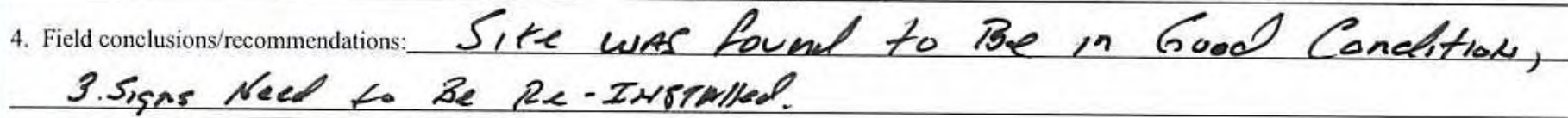 } \\
\hline \multicolumn{4}{|l|}{ F. CERTIFICATION } \\
\hline \multicolumn{4}{|c|}{$\begin{array}{l}\text { I have conducted an inspection of CAS 25-27-03, Polychlorinated Biphenyls Surface Contamination, in accordance with the procedures of the Post-Closure } \\
\text { Plan as recorded on this checklist, attached sheets, fieldyotesphotggraphs, and photograph logs. }\end{array}$} \\
\hline \multicolumn{2}{|c|}{ Chief Inspector's Signature: /s/ Glenn Richardson } & Date: & $12 / 13 / 07$ \\
\hline Printed Name: Glenn Recharels & & Title: & TASP MANAGER \\
\hline
\end{tabular}

Attachments (check if attached):

$\square$ Maintenance records 
CAU 529: AREA 25 CONTAMINATED MATERIALS 


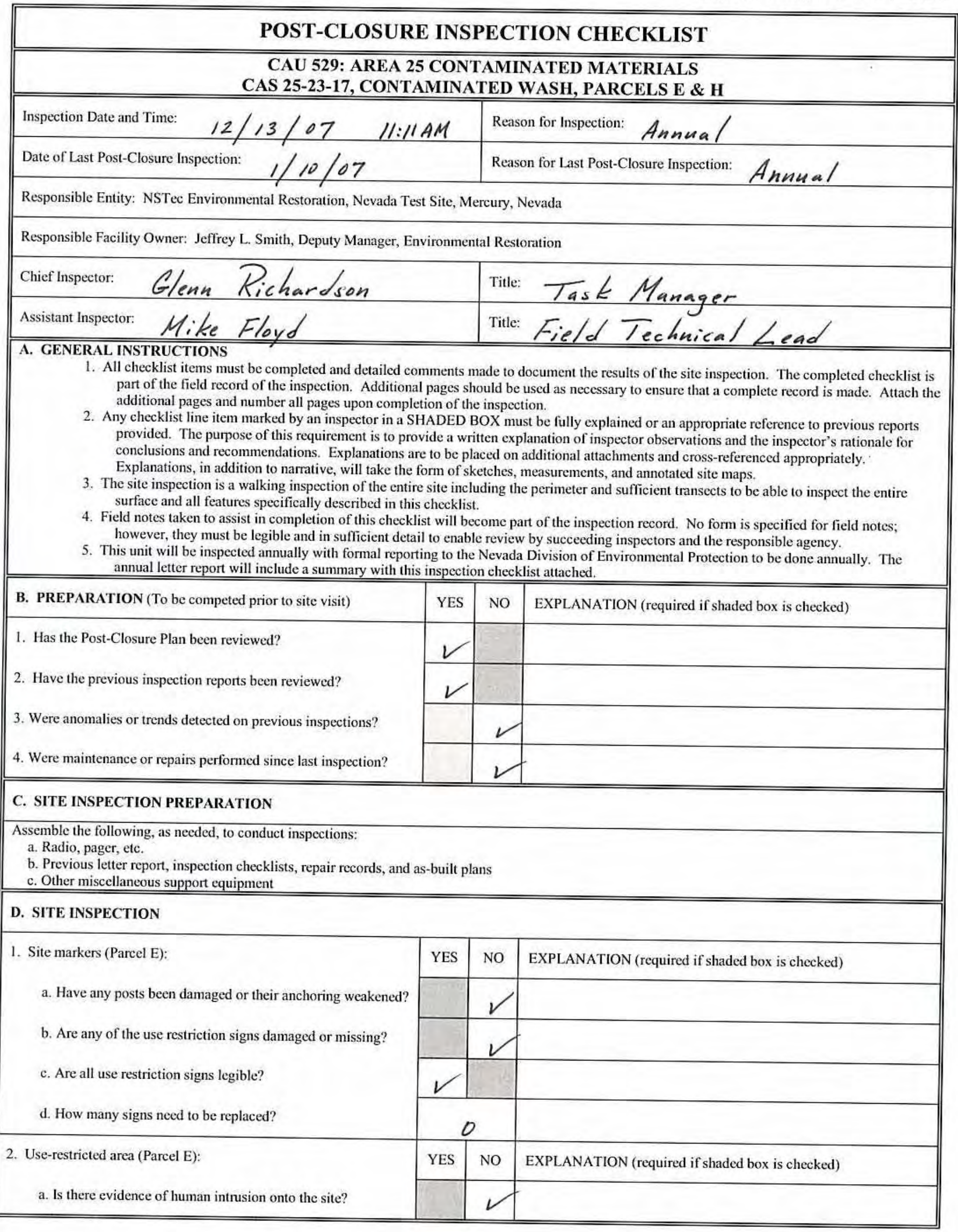




\section{POST-CLOSURE INSPECTION CHECKLIST \\ CAU 529: AREA 25 CONTAMINATED MATERIALS \\ CAS 25-23-17, CONTAMINATED WASH, PARCELS E \& H}

3. Site markers (Parcel H):

a. Have any posts been damaged or their anchoring weakened?

b. Are any of the use restriction signs damaged or missing?

c. Are all use restriction signs legible?

d. How many signs need to be replaced?

4. Use-restricted area (Parcel $\mathrm{H})$ :

a. Is there evidence of human intrusion onto the site?

5. Photograph Documentation (optional):

a. Have photographs been taken of the site?

If yes, how many photos were taken?

If yes, has a photographic log been prepared?

\section{E. FIELD CONCLUSIONS}

1. Are more frequent inspections required?

2. Are existing maintenance/repair actions satisfactory?

3. Is other maintenance/repair necessary?

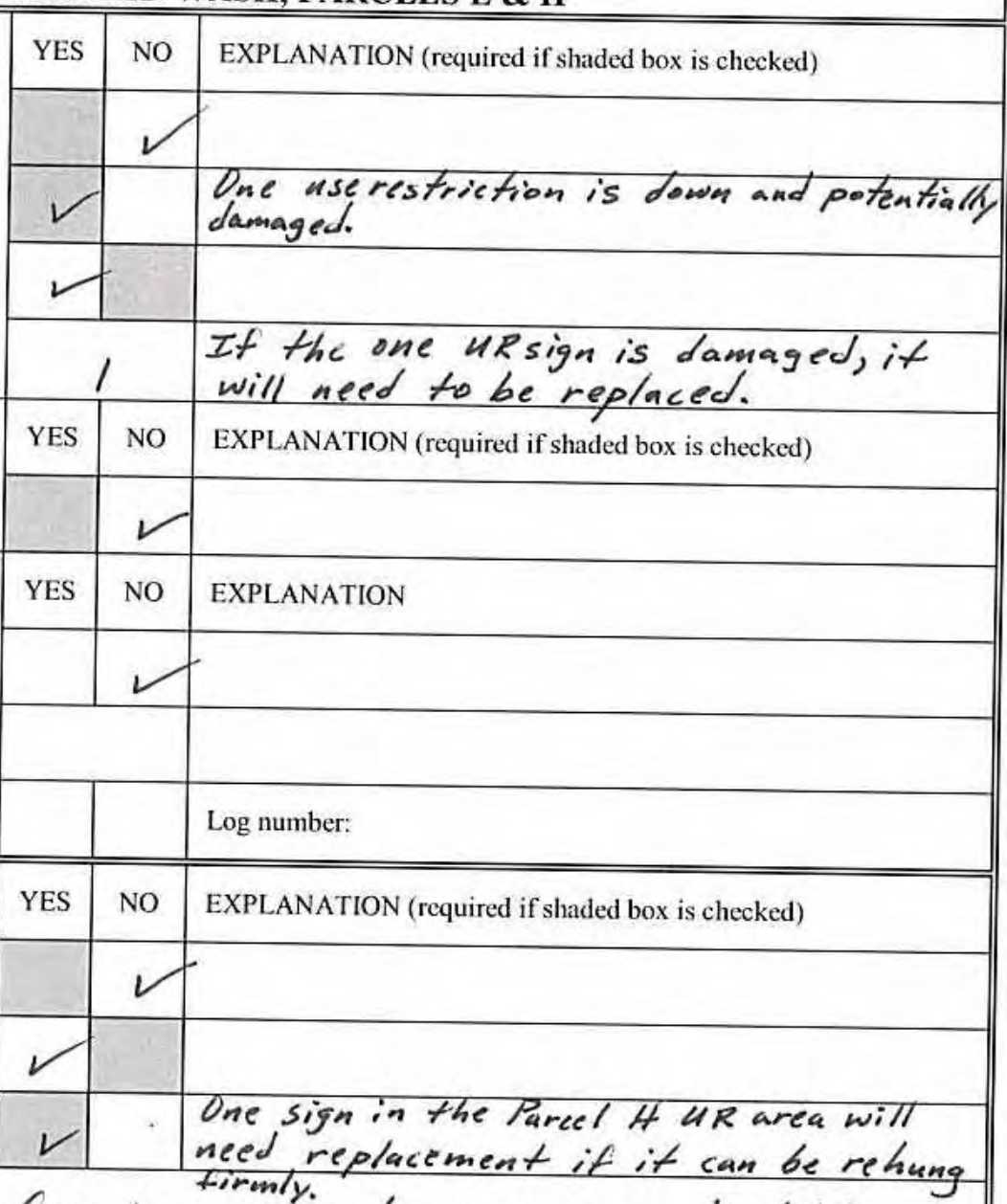

4. Field conclusions/recommendations: The wire fencing is strung very tightly and is in good condition. One of the use restriction sigus in Parcel It is down possibly due to high wind conditions in the area. A corrective action is necessary to rehang or replace the sign.

\section{F. CERTIFICATION}

I have conducted an inspection of CAS 25-23-17, Contaminated Wash Parcels E \& H, in accordance with the procedures of the Post-Closure Plan as recorded on this checklist, attached sheets, field notes, photographs, and photograph logs.

Chief Inspector's Signature: /s/ Glenn Richardson 
CAU 542: DISPOSAL HOLES 


\section{POST-CLOSURE INSPECTION CHECKLIST}

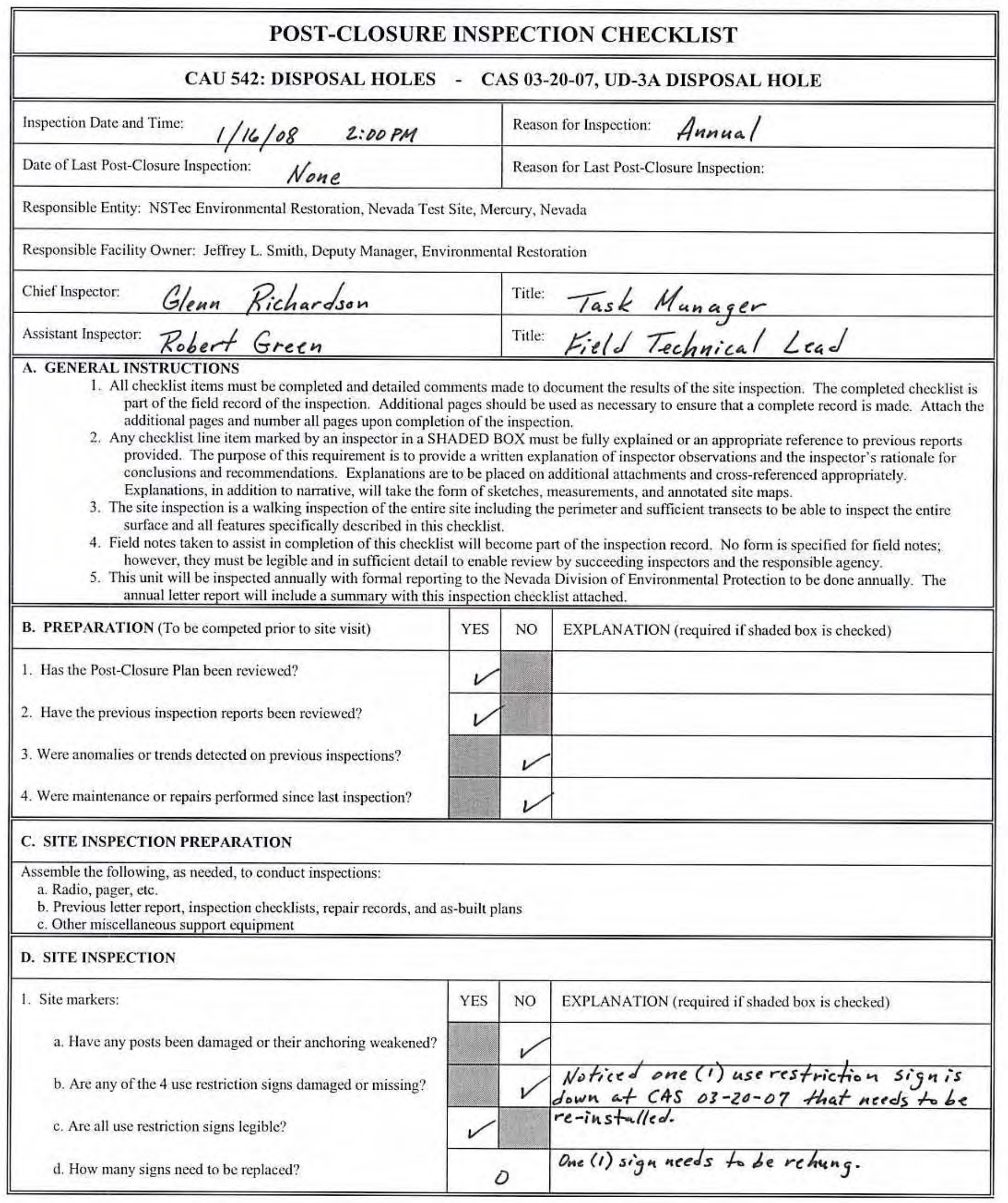


POST-CLOSURE INSPECTION CHECKLIST

CAU 542: DISPOSAL HOLES - CAS 03-20-07, UD-3A DISPOSAL HOLE

2. Photograph Documentation (optional):

a. Have photographs been taken of the site?

If yes, how many photos were taken?

If yes, has a photographic log been prepared?

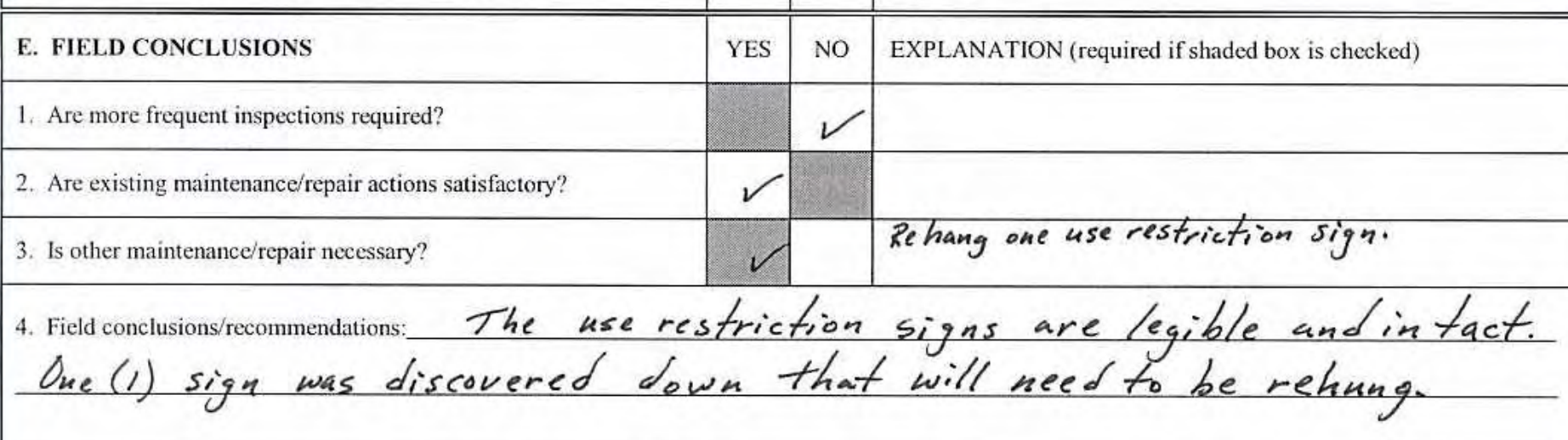

\section{F. CERTIFICATION}

I have conducted an inspection of CAS 03-20-07, UD-3a Disposal Hole, in accordance with the procedures of the Post-Closure Plan as recorded on this checklist, attached sheets, field notes, photographs, and photograph logs.

Chief Inspector's Signature: /s/ Glenn Richardson

Printed Name:

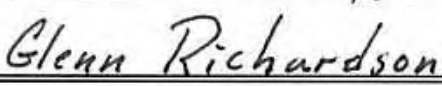

\begin{tabular}{l|l} 
Date: & $1 / 16 / 08$ \\
Title: Task Manager
\end{tabular} 
POST-CLOSURE INSPECTION CHECKLIST

CAU 542: DISPOSAL HOLES - CAS 03-20-09, UD-3B DISPOSAL HOLE

\begin{tabular}{||l|l||}
\hline \hline Inspection Date and Time: $1 / 16 / 08 \quad 2: 00 \mathrm{PM}$ & Reason for Inspection: Annual \\
\hline Date of Last Post-Closure Inspection: None & Reason for Last Post-Closure Inspection: \\
\hline
\end{tabular}

Responsible Entity: NSTec Environmental Restoration, Nevada Test Site, Mercury, Nevada

Responsible Facility Owner: Jeffrey L. Smith, Deputy Manager, Environmental Restoration

\begin{tabular}{|l|l}
\hline Chief inspector: Glenn Richardson & Title: Task Manager \\
\hline Assistant Inspector: Robert Green & Title: Field Techaical Lead
\end{tabular}

\section{A. GENERAL INSTRUCTIONS}

1. All checklist items must be completed and detailed comments made to document the results of the site inspection. The completed checklist is part of the field record of the inspection. Additional pages should be used as necessary to ensure that a complete record is made. Attach the additional pages and number all pages upon completion of the inspection.

2. Any checklist line item marked by an inspector in a SHADED BOX must be fully explained or an appropriate reference to previous reports provided. The purpose of this requirement is to provide a written explanation of inspector observations and the inspector's rationale for conclusions and recommendations. Explanations are to be placed on additional attachments and cross-referenced appropriately. Explanations, in addition to narrative, will take the form of sketches, measurements, and annotated site maps.

3. The site inspection is a walking inspection of the entire site including the perimeter and sufficient transects to be able to inspect the entire surface and all features specifically described in this checklist.

4. Field notes taken to assist in completion of this checklist will become part of the inspection record. No form is specified for field notes; however, they must be legible and in sufficient detail to enable review by succeeding inspectors and the responsible agency.

5. This unit will be inspected annually with formal reporting to the Nevada Division of Environmental Protection to be done annually. The annual letter report will include a summary with this inspection checklist attached.

\begin{tabular}{|c|c|c|c|}
\hline B. PREPARATION (To be competed prior to site visit) & YES & NO & EXPLANATION (required if shaded box is checked) \\
\hline 1. Has the Post-Closure Plan been reviewed? & & & \\
\hline 2. Have the previous inspection reports been reviewed? & & & \\
\hline 3. Were anomalies or trends detected on previous inspections? & & & \\
\hline 4. Were maintenance or repairs performed since last inspection? & & & \\
\hline
\end{tabular}

\section{SITE INSPECTION PREPARATION}

Assemble the following, as needed, to conduct inspections:

a. Radio, pager, etc.

b. Previous letter report, inspection checklists, repair records, and as-built plans

c. Other miscellaneous support equipment

\section{SITE INSPECTION}

1. Site markers:

a. Have any posts been damaged or their anchoring weakened?

b. Are any of the 4 use restriction signs damaged or missing?

c. Are all use restriction signs legible?

d. How many signs need to be replaced?

\begin{tabular}{|l|l|l||}
\hline YES & NO & EXPLANATION (required if shaded box is checked) \\
\hline & & \\
\hline & & \\
\hline & & \\
\hline
\end{tabular}




\section{POST-CLOSURE INSPECTION CHECKLIST}

\section{CAU 542: DISPOSAL HOLES - CAS 03-20-09, UD-3B DISPOSAL HOLE}

2. Photograph Documentation (optional):

a. Have photographs been taken of the site?

If yes, how many photos were taken?

If yes, has a photographic $\log$ been prepared?

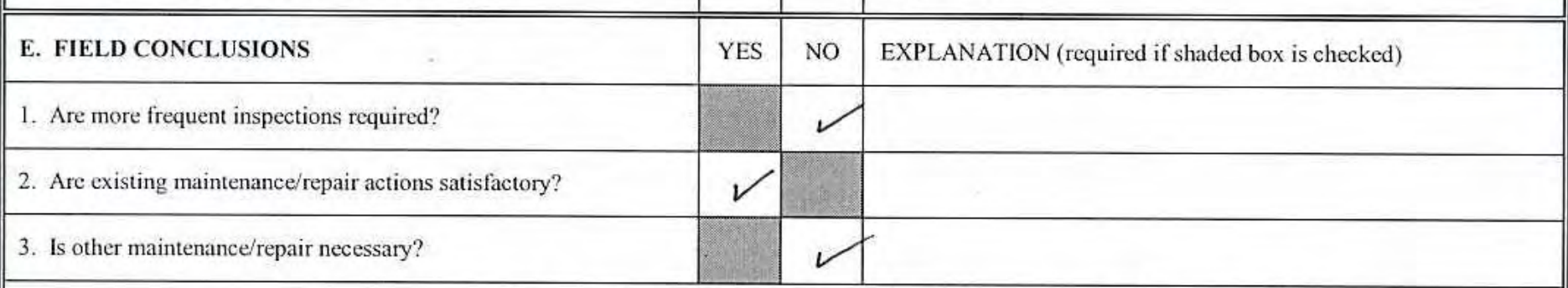

4. Field conclusions/recommendations:_ Overall site conditions at this site are excellent. There are no corrective actions reguired.

\section{F. CERTIFICATION}

I have conducted an inspection of CAS 03-20-07, UD-3b Disposal Hole, in accordance with the procedures of the Post-Closure Plan as recorded on this checklist, attached sheets, field notes, photographs, and photograph logs.

Chief Inspector's Signature: / / $/$ Glenn Richardson Printed Name: 
POST-CLOSURE INSPECTION CHECKLIST

\section{CAU 542: DISPOSAL HOLES - CAS 03-20-10, UD-3C DISPOSAL HOLE}

\begin{tabular}{||l|l|}
\hline \hline Inspection Date and Time: $/ / 16 / 08 \quad 2: 32 \mathrm{PM}$ & Reason for Inspection: Annua/ \\
\hline Date of Last Post-Closure Inspection: & Rone
\end{tabular}

Responsible Entity: NSTec Environmental Restoration, Nevada Test Site, Mercury, Nevada

Responsible Facility Owner: Jeffrey L. Smith, Deputy Manager, Environmental Restoration

\begin{tabular}{|l|l}
\hline Chief Inspector: Glenn Kichardson & Title: Task Manager \\
\hline Assistant Inspector: Robert Green & Title: Field Techuical Lead
\end{tabular}

A. GENERAL INSTRUCTIONS

1. All checklist items must be completed and detailed comments made to document the results of the site inspection. The completed checklist is part of the field record of the inspection. Additional pages should be used as necessary to ensure that a complete record is made. Attach the additional pages and number all pages upon completion of the inspection.

2. Any checklist line item marked by an inspector in a SHADED BOX must be fully explained or an appropriate reference to previous reports provided. The purpose of this requirement is to provide a written explanation of inspector observations and the inspector's rationale for conclusions and recommendations. Explanations are to be placed on additional attachments and cross-referenced appropriately. Explanations, in addition to narrative, will take the form of sketches, measurements, and annotated site maps.

3. The site inspection is a walking inspection of the entire site including the perimeter and sufficient transects to be able to inspect the entire surface and all features specifically described in this checklist.

4. Field notes taken to assist in completion of this checklist will become part of the inspection record. No form is specified for field notes; however, they must be legible and in sufficient detail to enable review by succeeding inspectors and the responsible agency.

5. This unit will be inspected annually with formal reporting to the Nevada Division of Environmental Protection to be done annually. The annual letter report will include a summary with this inspection checklist attached.

\begin{tabular}{l|l|l|l} 
B. PREPARATION (To be competed prior to site visit) & YES & NO & EXPLANATION (required if shaded box is checked)
\end{tabular}

1. Has the Post-Closure Plan been reviewed?

2. Have the previous inspection reports been reviewed?

3. Were anomalies or trends detected on previous inspections?

4. Were maintenance or repairs performed since last inspection?

\section{SITE INSPECTION PREPARATION}

Assemble the following, as needed, to conduct inspections:
a. Radio, pager, etc.
b. Previous letter report, inspection checklists, repair records, and as-built plans
c. Other miscellaneous support equipment

\section{SITE INSPECTION}

1. Site markers:

a. Have any posts been damaged or their anchoring weakened?

b. Are any of the 4 use restriction signs damaged or missing?

c. Are all use restriction signs legible?

d. How many signs need to be replaced?

\begin{tabular}{|l|l|l|} 
YES & NO & EXPLANATION (required if shaded box is checked) \\
\hline & \multicolumn{1}{|c|}{$\begin{array}{l}\text { One (1) use restriction sign is loose due to } \\
\text { high winds within the general area. }\end{array}$} \\
\hline & One (1) sign will need to be fightened. \\
\hline
\end{tabular}




\section{POST-CLOSURE INSPECTION CHECKLIST}

\section{CAU 542: DISPOSAL HOLES - CAS 03-20-10, UD-3C DISPOSAL HOLE}

2. Photograph Documentation (optional):

a. Have photographs been taken of the site?

If yes, how many photos were taken?

If yes, has a photographic log been prepared?

\section{E. FIELD CONCLUSIONS}

1. Are more frequent inspections required?

2. Are existing maintenance/repair actions satisfactory?

3. Is other maintenance/repair necessary?

\begin{tabular}{|c|c|l|l}
\hline \multicolumn{2}{|c|}{ YES } & NO & EXPLANATION \\
\hline & & \\
\hline & & Log number: \\
\hline YES & NO & EXPLANATION (required if shaded box is checked) \\
\hline & $\nearrow$ & \\
\hline & & \\
\hline & & Tighten one (I) loose use restriction sign. \\
\hline
\end{tabular}

4. Field conclusions/recommendations: The use restriction signs are leyible and in good condition. Due to high winds in the general area, one sign is loose and needs to be tightened.

\section{F. CERTIFICATION}

I have conducted an inspection of CAS 03-20-07, UD-3c Disposal Hole, in accordance with the procedures of the Post-Closure Plan as recorded on this checklist, attached sheets, field notes, photographs, and photograph logs.

Chief Inspector's Signature: /s/ Glenn Richardson

Printed Name: 


\section{POST-CLOSURE INSPECTION CHECKLIST}

\section{CAU 542: DISPOSAL HOLES - CAS 03-20-11, UD-3D DISPOSAL HOLE}

\begin{tabular}{|l|l|}
\hline \hline Inspection Date and Time: $\quad 1 / 16 / 08 \quad 2: 2 / \mathrm{PM}$ & Reason for Inspection: Annual \\
\hline Date of Last Post-Closure Inspection: None & Reason for Last Post-Closure Inspection: \\
\hline
\end{tabular}

Responsible Entity: NSTec Environmental Restoration, Nevada Test Site, Mercury, Nevada

Responsible Facility Owner: Jeffrey L. Smith, Deputy Manager, Environmental Restoration

\begin{tabular}{l|l}
\hline Chief Inspector: Glenn Richardson & Title: Task Manager \\
\hline Assistant inspector: Dobert Green & Title: Field Technical
\end{tabular}

A. GENERAL INSTRUCTIONS

1. All checklist items must be completed and detailed comments made to document the results of the site inspection. The completed checklist is part of the field record of the inspection. Additional pages should be used as necessary to ensure that a complete record is made. Attach the additional pages and number all pages upon completion of the inspection.

2. Any checklist line item marked by an inspector in a SHADED BOX must be fully explained or an appropriate reference to previous reports provided. The purpose of this requirement is to provide a written explanation of inspector observations and the inspector's rationale for conclusions and recommendations. Explanations are to be placed on additional attachments and cross-referenced appropriately. Explanations, in addition to narrative, will take the form of sketches, measurements, and annotated site maps.

3. The site inspection is a walking inspection of the entire site including the perimeter and sufficient transects to be able to inspect the entire surface and all features specifically described in this checklist.

4. Field notes taken to assist in completion of this checklist will become part of the inspection record. No form is specified for field notes; however, they must be legible and in sufficient detail to enable review by succeeding inspectors and the responsible agency.

5. This unit will be inspected annually with formal reporting to the Nevada Division of Environmental Protection to be done annually. The annual letter report will include a summary with this inspection checklist attached.

B. PREPARATION (To be competed prior to site visit)

1. Has the Post-Closure Plan been reviewed?

2. Have the previous inspection reports been reviewed?

3. Were anomalies or trends detected on previous inspections?

4. Were maintenance or repairs performed since last inspection?

\section{SITE INSPECTION PREPARATION}

Assemble the following, as needed, to conduct inspections:

a. Radio, pager, etc.

b. Previous letter report, inspection checklists, repair records, and as-built plans

c. Other miscellaneous support equipment

\section{SITE INSPECTION}

1. Site markers:

a. Have any posts been damaged or their anchoring weakened?

b. Are any of the 4 use restriction signs damaged or missing?

c. Are all use restriction signs legible?

d. How many signs need to be replaced?

\begin{tabular}{|l|l|l||}
\hline YES & NO & EXPLANATION (required if shaded box is checked) \\
\hline & & \\
\hline & & \\
\hline & & \\
\hline & & \\
\hline
\end{tabular}




\section{POST-CLOSURE INSPECTION CHECKLIST}

\section{CAU 542: DISPOSAL HOLES - CAS 03-20-11, UD-3D DISPOSAL HOLE}

2. Photograph Documentation (optional):

a. Have photographs been taken of the site?

If yes, how many photos were taken?

If yes, has a photographic $\log$ been prepared?

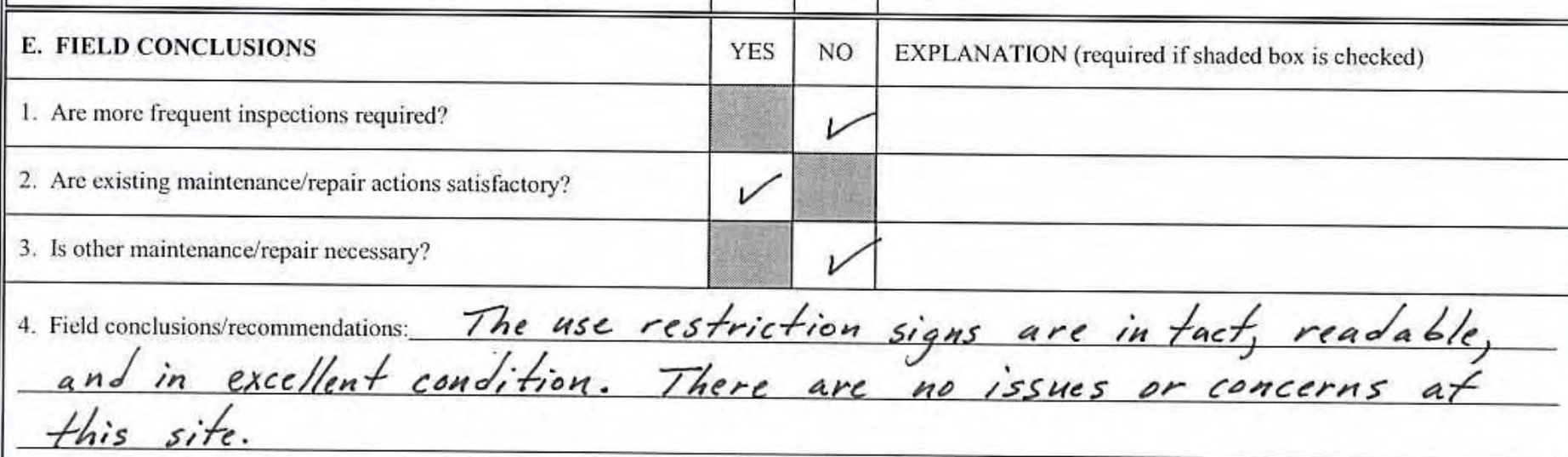

\section{F. CERTIFICATION}

I have conducted an inspection of CAS 03-20-11, UD-3d Disposal Hole, in accordance with the procedures of the Post-Closure Plan as recorded on this checklist, attached sheets, field notes, photographs, and photograph logs.

\begin{tabular}{|l|l|l}
\hline Chief Inspector's Signature: /s/ Glenn Richardson & Date: $1 / 16 / 08$ \\
\hline Printed Name: Glenn Kichardson & Title: Task Manaqer \\
\hline
\end{tabular}




\section{POST-CLOSURE INSPECTION CHECKLIST}

\section{CAU 542: DISPOSAL HOLES - CAS 06-20-03, UD-6 AND UD-6S DISPOSAL HOLES}

\begin{tabular}{||l|l|}
\hline \hline Inspection Date and Time: $1 / 16 / 08 \quad 2: 13 \mathrm{PM}$ & Reason for Inspection: Annua/ $/$ \\
\hline Date of Last Post-Closure Inspection: None & Reason for Last Post-Closure Inspection: \\
\hline
\end{tabular}

Responsible Entity: NSTec Environmental Restoration, Nevada Test Site, Mercury, Nevada

Responsible Facility Owner: Jeffrey L. Smith, Deputy Manager, Environmental Restoration

\begin{tabular}{|l|l}
\hline chief Inspector: Glenn Richardson & Title: Task Manager \\
\hline Assistant Inspector: Robert Green & Title: Field Technical Lead
\end{tabular}

A. GENERAL INSTRUCTIONS

1. All checklist items must be completed and detailed comments made to document the results of the site inspection. The completed checklist is part of the field record of the inspection. Additional pages should be used as necessary to ensure that a complete record is made. Attach the additional pages and number all pages upon completion of the inspection.

2. Any checklist line item marked by an inspector in a SHADED BOX must be fully explained or an appropriate reference to previous reports provided. The purpose of this requirement is to provide a written explanation of inspector observations and the inspector's rationale for conclusions and recommendations. Explanations are to be placed on additional attachments and cross-referenced appropriately. Explanations, in addition to narrative, will take the form of sketches, measurements, and annotated site maps.

3. The site inspection is a walking inspection of the entire site including the perimeter and sufficient transects to be able to inspect the entire surface and all features specifically described in this checklist.

4. Field notes taken to assist in completion of this checklist will become part of the inspection record. No form is specified for field notes; however, they must be legible and in sufficient detail to enable review by succeeding inspectors and the responsible agency.

5. This unit will be inspected annually with formal reporting to the Nevada Division of Environmental Protection to be done annually. The annual letter report will include a summary with this inspection checklist attached.

B. PREPARATION (To be competed prior to site visit)

1. Has the Post-Closure Plan been reviewed?

2. Have the previous inspection reports been reviewed?

3. Were anomalies or trends detected on previous inspections?

4. Were maintenance or repairs performed since last inspection?

\begin{tabular}{|l|l|l|}
\hline YES & NO & EXPLANATION (required if shaded box is checked) \\
\hline & & \\
\hline
\end{tabular}

\section{SITE INSPECTION PREPARATION}

Assemble the following, as needed, to conduct inspections:

a. Radio, pager, etc.

b. Previous letter report, inspection checklists, repair records, and as-built plans

c. Other miscellaneous support equipment

\section{SITE INSPECTION}

1. Site markers:

a. Have any posts been damaged or their anchoring weakened?

b. Are any of the 4 use restriction signs damaged or missing?

c. Are all use restriction signs legible?

d. How many signs need to be replaced?

\begin{tabular}{|l|l|l|}
\hline YES & NO & EXPLANATION (required if shaded box is checked) \\
\hline & & \\
\hline & & \\
\hline & & \\
\hline & & \\
\hline
\end{tabular}




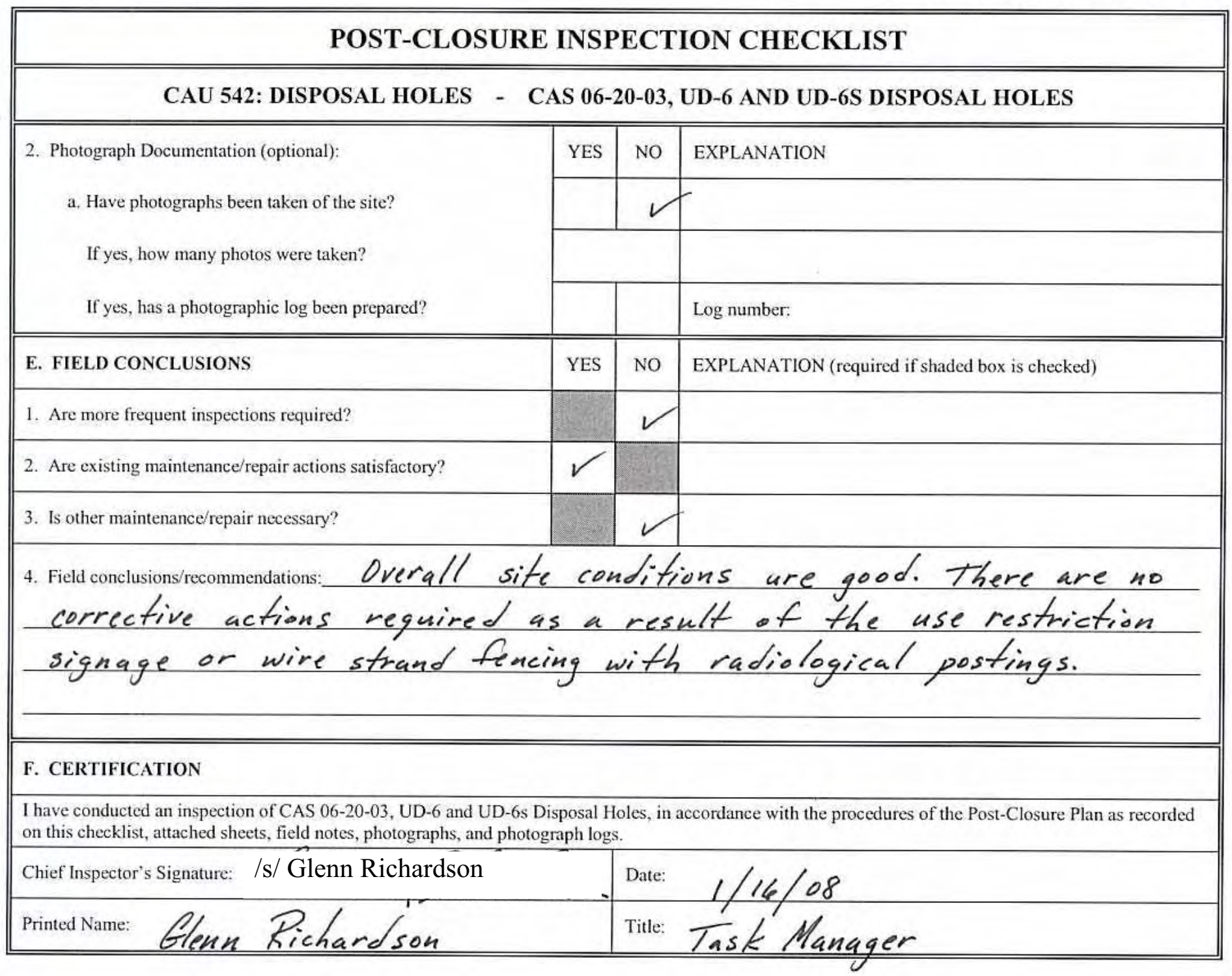


CAU 551: AREA 12 MUCKPILES 


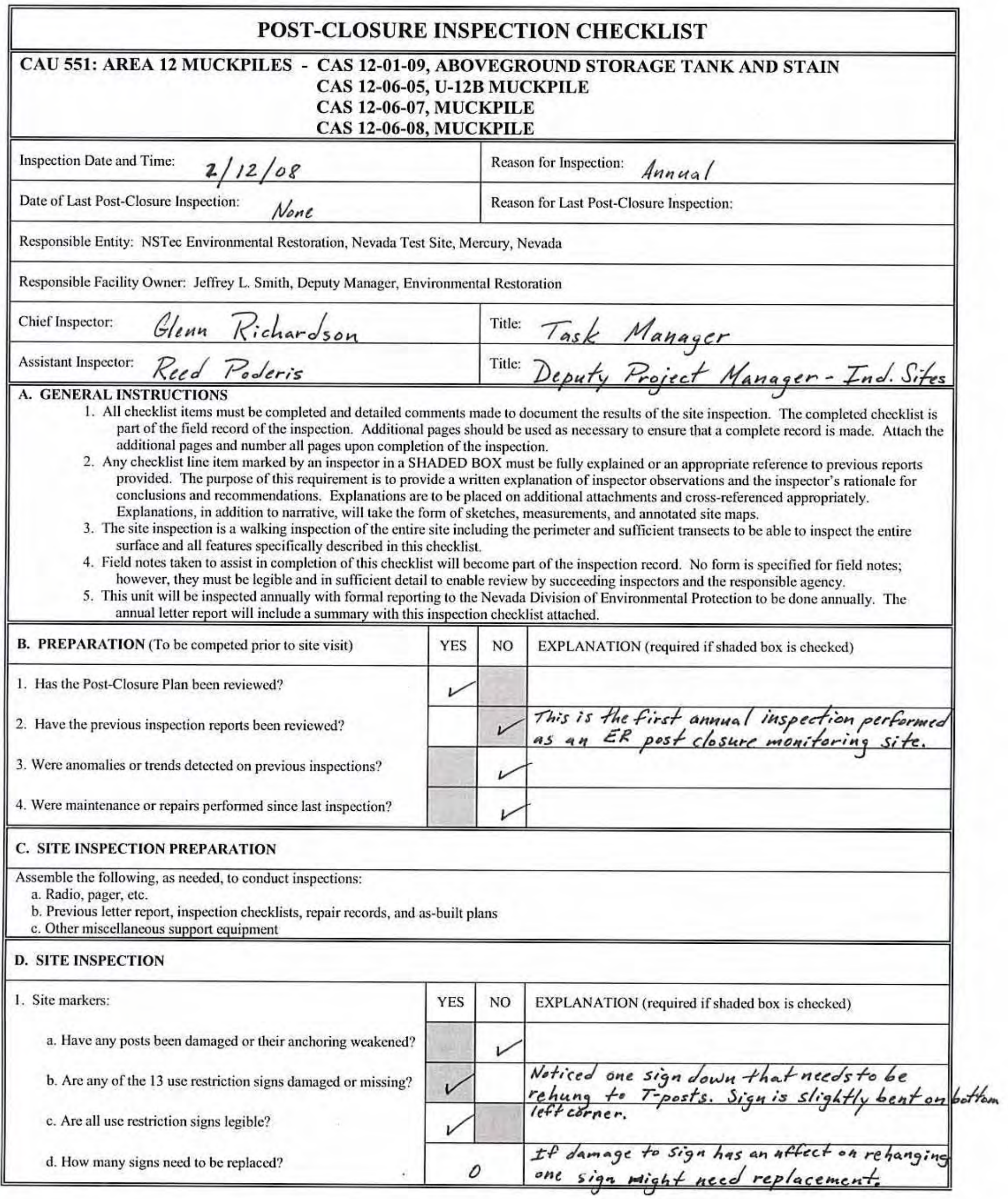




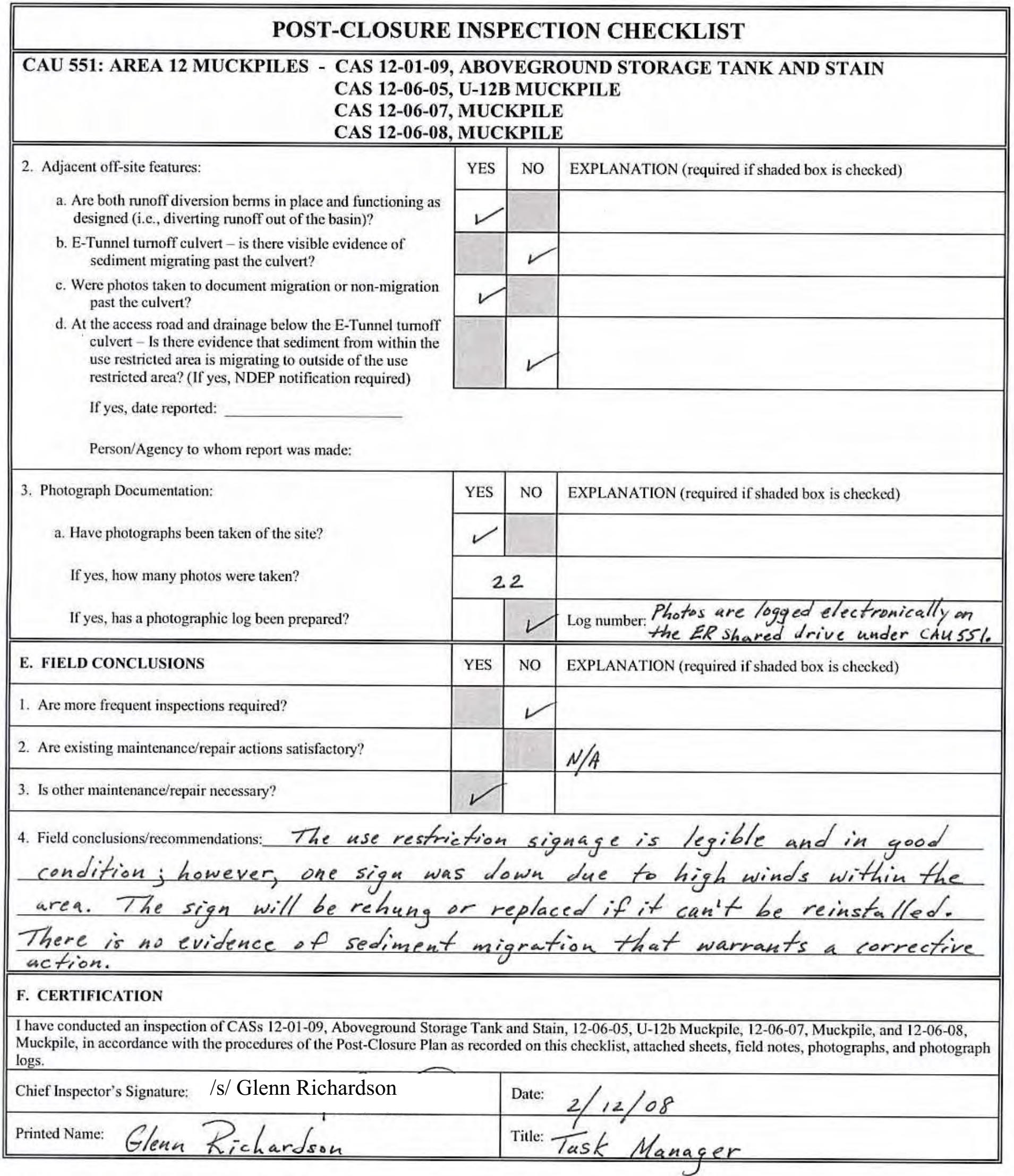

Attachments (check if attached):

口Photos 
CAU 551, AREA 12 MUCKPILES

E-TunNel TurnofF Culvert

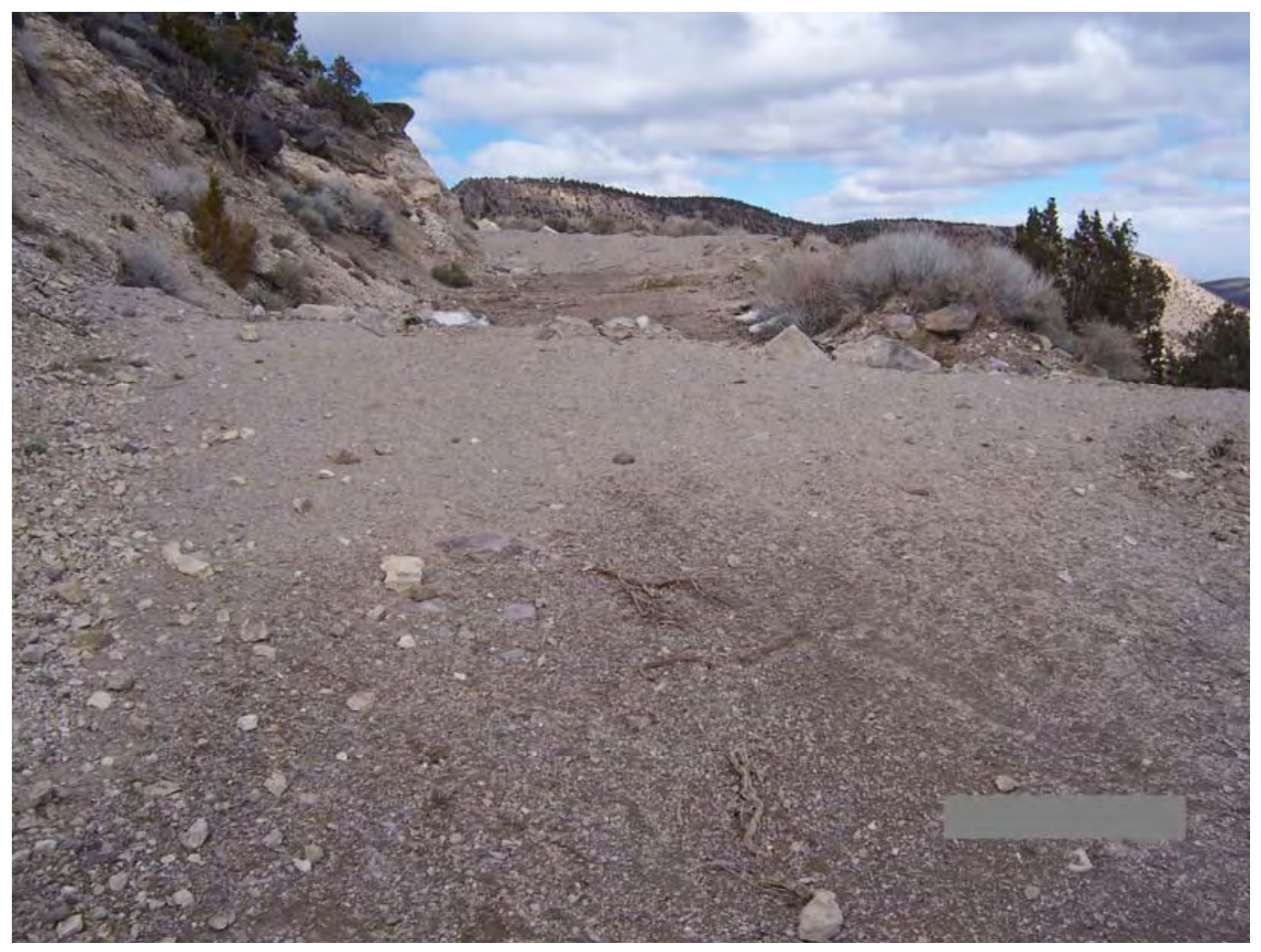

Upper and Lower Diversion Berms, 02/12/2008

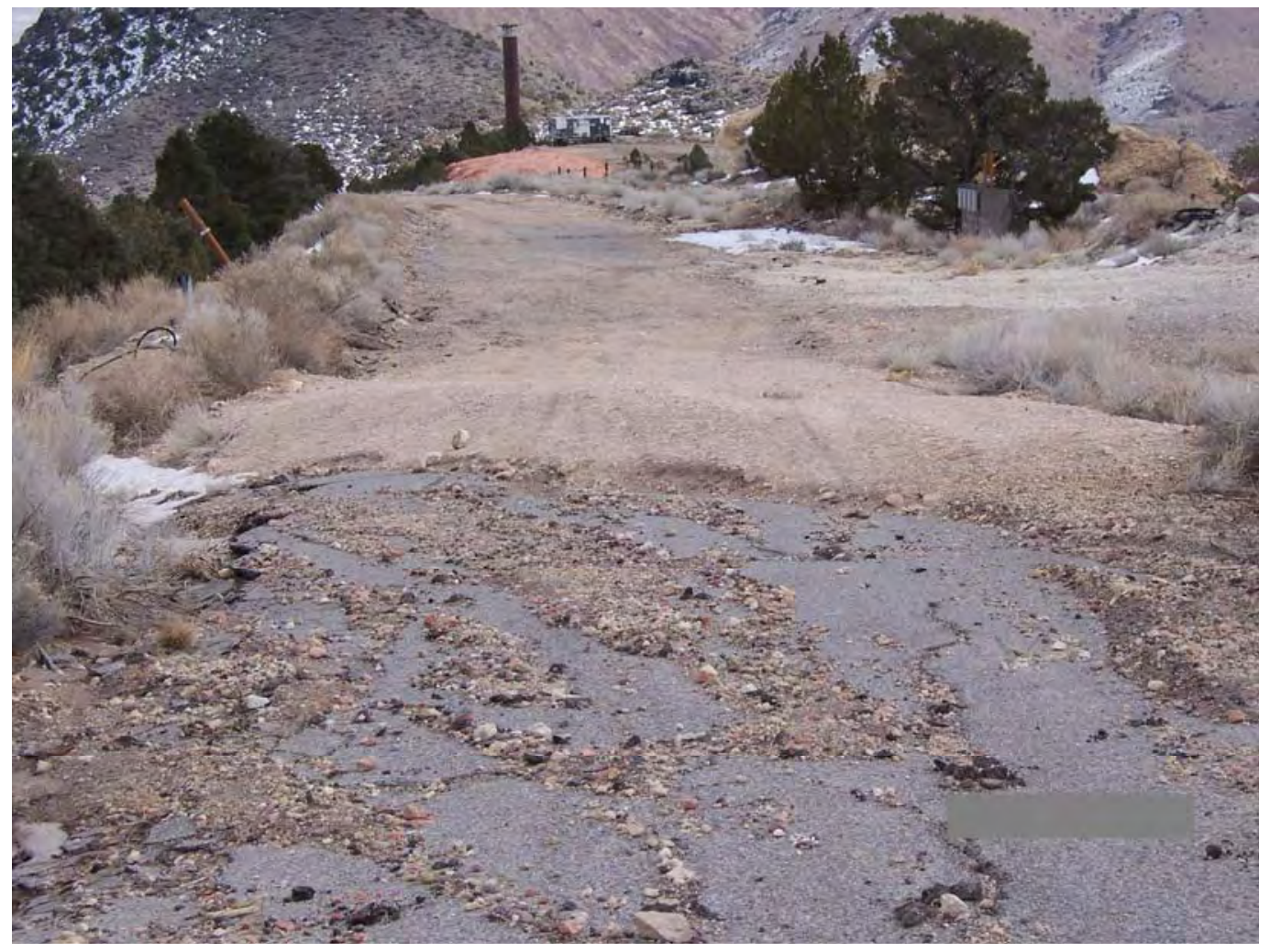

Water Diversion Berm \#1, 02/12/2008 
CAU 551, AREA 12 MUCKPILES

E-TunNel Turnoff Culvert

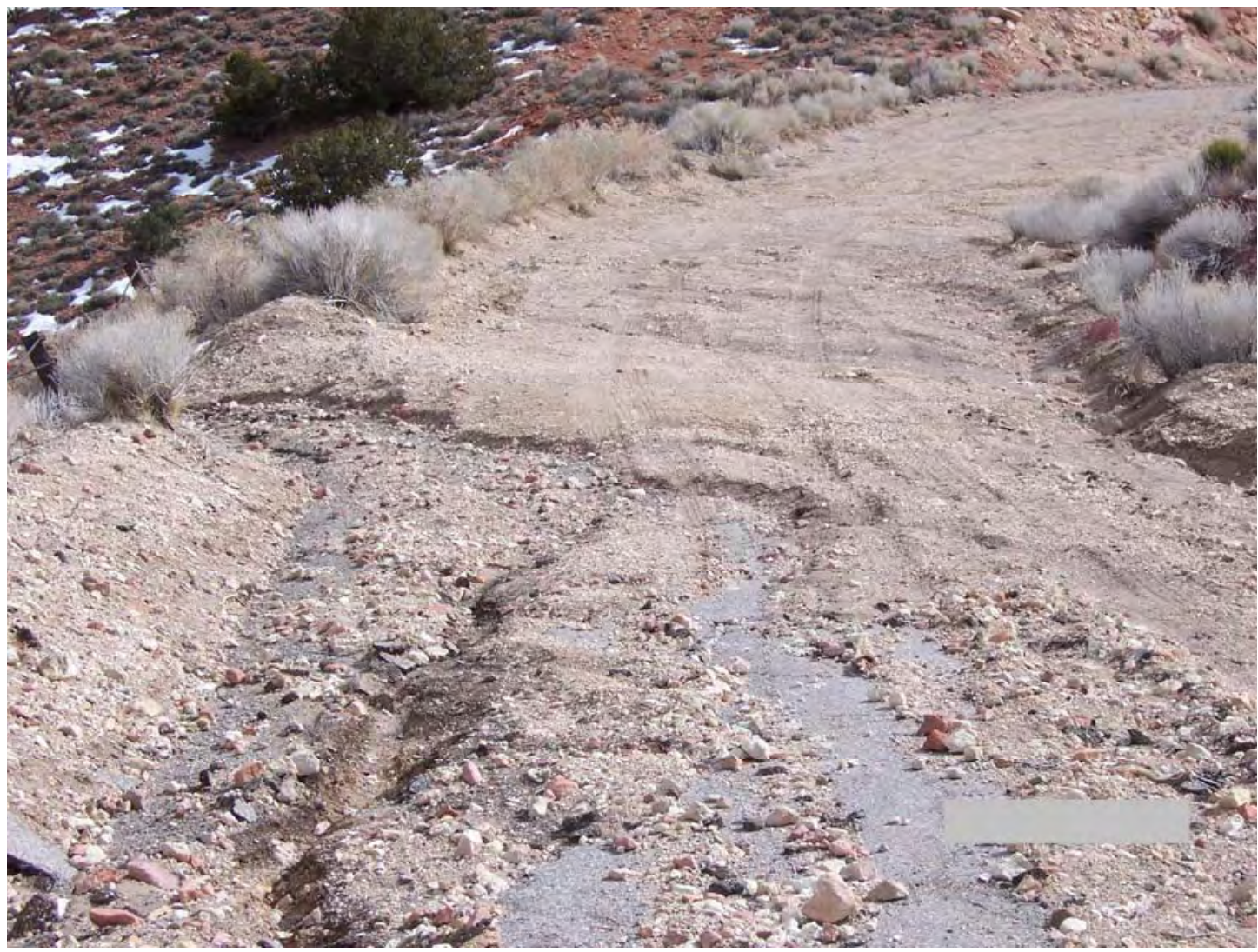

Water Diversion Berm \#2, 02/12/2008 
CAU 552: AREA 12 MUCKPILE AND PONDS 


\section{POST-CLOSURE INSPECTION CHECKLIST}

\section{CAU 552: AREA 12 MUCKPILE AND PONDS - CAS 12-23-05, PONDS}

\begin{tabular}{||l|l|}
\hline \hline Inspection Date and Time: $1 / 23 / 08 \quad / /: 12 \mathrm{AM}$ & Reason for Inspection: Annual \\
\hline Date of Last Post-Closure Inspection: & Reason for Last Post-Closure Inspection: \\
\hline
\end{tabular}

Responsible Entity: NSTec Environmental Restoration, Nevada Test Site, Mercury, Nevada

Responsible Facility Owner: Jeffrey L. Smith, Deputy Manager, Environmental Restoration

\begin{tabular}{l|l} 
chief Inspector: Glenn Richardson & Title: Task Manager \\
\hline Assistant Inspector: Robert Green & Title: Field Technica/ Lead
\end{tabular}

A. GENERAL INSTRUCTIONS

1. All checklist items must be completed and detailed comments made to document the results of the site inspection. The completed checklist is part of the field record of the inspection. Additional pages should be used as necessary to ensure that a complete record is made. Attach the additional pages and number all pages upon completion of the inspection.

2. Any checklist line item marked by an inspector in a SHADED BOX must be fully explained or an appropriate reference to previous reports provided. The purpose of this requirement is to provide a written explanation of inspector observations and the inspector's rationale for conclusions and recommendations. Explanations are to be placed on additional attachments and cross-referenced appropriately. Explanations, in addition to narrative, will take the form of sketches, measurements, and annotated site maps.

3. The site inspection is a walking inspection of the entire site including the perimeter and sufficient transects to be able to inspect the entire surface and all features specifically described in this checklist.

4. Field notes taken to assist in completion of this checklist will become part of the inspection record. No form is specified for field notes; however, they must be legible and in sufficient detail to enable review by succeeding inspectors and the responsible agency.

5. This unit will be inspected annually with formal reporting to the Nevada Division of Environmental Protection to be done annually. The annual letter report will include a summary with this inspection checklist attached.

\begin{tabular}{|c|c|c|c|}
\hline B. PREPARATION (To be competed prior to site visit) & YES & NO & EXPLANATION (required if shaded box is checked) \\
\hline 1. Has the Post-Closure Plan been reviewed? & & & \\
\hline 2. Have the previous inspection reports been reviewed? & & & \\
\hline 3. Were anomalies or trends detected on previous inspections? & & & \\
\hline 4. Were maintenance or repairs performed since last inspection? & & & \\
\hline
\end{tabular}

\section{SITE INSPECTION PREPARATION}

Assemble the following, as needed, to conduct inspections:

a. Radio, pager, etc.

b. Previous letter report, inspection checklists, repair records, and as-built plans

c. Other miscellaneous support equipment

\section{SITE INSPECTION}

1. Site markers:

a. Is there damage to the fence or rope?

b. Have any posts been damaged or their anchoring weakened?

c. Are any of the radiological posting signs damaged or missing?

d. Are all radiological posting signs legible?

e. How many signs need to be replaced?

\begin{tabular}{|l|l|l|}
\hline YES & NO & EXPLANATION (required if shaded box is checked) \\
\hline & \multicolumn{1}{|l|}{$\begin{array}{l}\text { Noticed a strand of barb wire to be in tact, but } \\
\text { alittle }\end{array}$} \\
\hline & \\
\hline & \\
\hline & \\
\hline
\end{tabular}




\section{POST-CLOSURE INSPECTION CHECKLIST}

\section{CAU 552: AREA 12 MUCKPILE AND PONDS - CAS 12-23-05, PONDS}

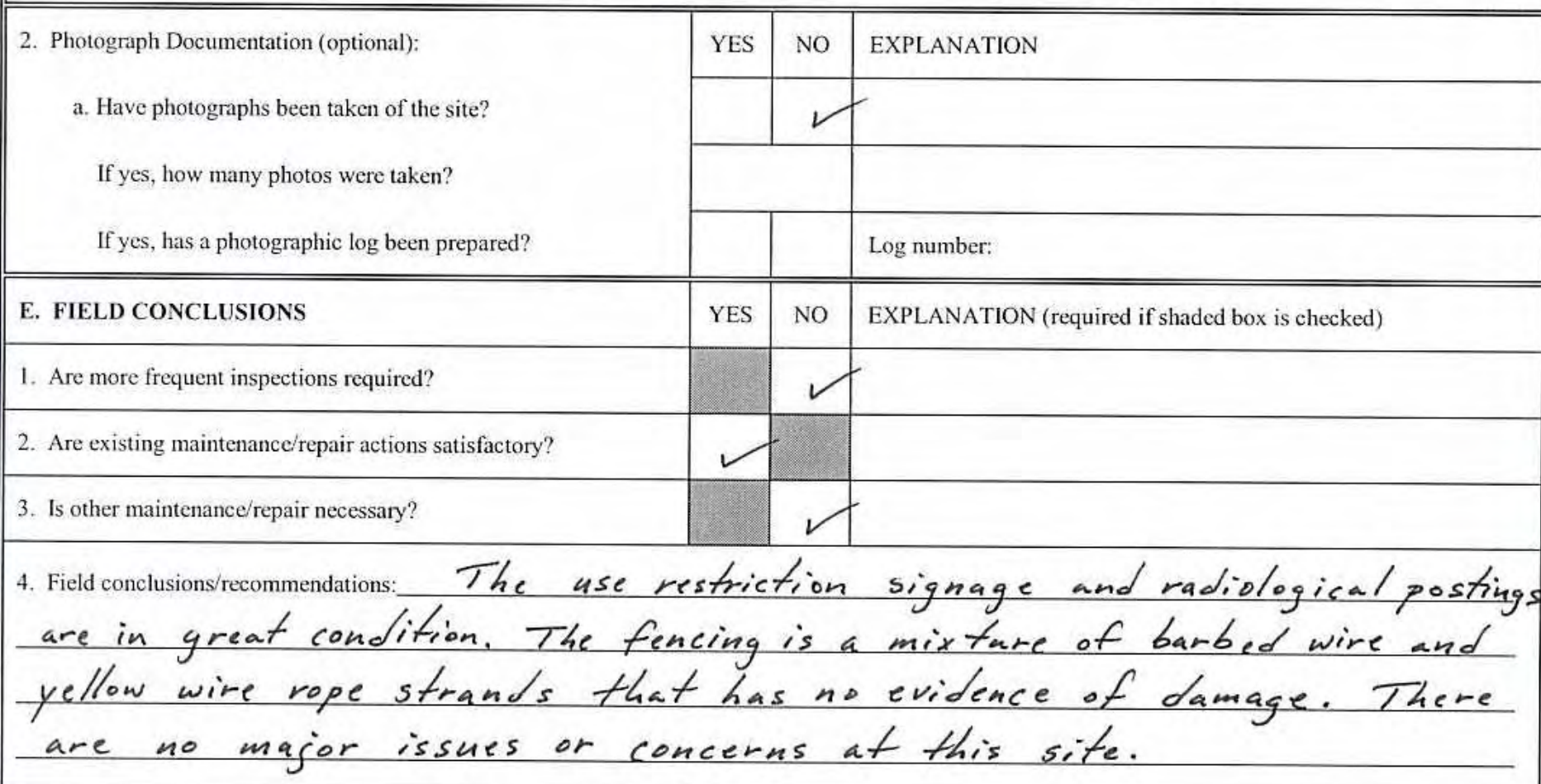

\section{F. CERTIFICATION}

I have conducted an inspection of CAS 12-23-05, Ponds, in accordance with the procedures of the Post-Closure Plan as recorded on this checklist, attached sheets, field notes, photographs, and photograph logs.

\begin{tabular}{l|l}
\hline Chief Inspector's Signature: /s/ Glenn Richardson & Date: 1/23/08 \\
\hline Printed Name: Glenn Richardson & Title: Task Manager \\
\hline
\end{tabular}


CAU 554: AREA 23 RELEASE SITE 


\section{POST-CLOSURE INSPECTION CHECKLIST}

CAU 554: AREA 23 RELEASE SITE - CAS 23-02-08, USTS 23-115-1,2,3/SPILL NO. 530-90-002

\begin{tabular}{||l|l|}
\hline \hline Inspection Date and Time: $1 / 23 / 08 \quad 3: 22 \mathrm{PM}$ & Reason for Inspection: Annual \\
\hline Date of Last Post-Closure Inspection: $12 / 28 / 06$ & Reason for Last Post-Closure Inspection: Annua/ \\
\hline
\end{tabular}

Responsible Entity: NSTec Environmental Restoration, Nevada Test Site, Mercury, Nevada

Responsible Facility Owner: Jeffrey L. Smith, Deputy Manager, Environmental Restoration

\begin{tabular}{|l|l}
\hline Chief Inspector: Gleun Richardson & Title: Task Manager \\
\hline Assistant inspector: Robert Green & Title: Field Technical Lead
\end{tabular}

A. GENERAL INSTRUCTIONS

1. All checklist items must be completed and detailed comments made to document the results of the site inspection. The completed checklist is part of the field record of the inspection. Additional pages should be used as necessary to ensure that a complete record is made. Attach the additional pages and number all pages upon completion of the inspection.

2. Any checklist line item marked by an inspector in a SHADED BOX must be fully explained or an appropriate reference to previous reports provided. The purpose of this requirement is to provide a written explanation of inspector observations and the inspector's rationale for conclusions and recommendations. Explanations are to be placed on additional attachments and cross-referenced appropriately. Explanations, in addition to narrative, will take the form of sketches, measurements, and annotated site maps.

3. The site inspection is a walking inspection of the entire site including the perimeter and sufficient transects to be able to inspect the entire surface and all features specifically described in this checklist.

4. Field notes taken to assist in completion of this checklist will become part of the inspection record. No form is specified for field notes; however, they must be legible and in sufficient detail to enable review by succeeding inspectors and the responsible agency.

5. This unit will be inspected annually with formal reporting to the Nevada Division of Environmental Protection to be done annually. The annual letter report will include a summary with this inspection checklist attached.

B. PREPARATION (To be competed prior to site visit)

1. Has the Post-Closure Plan been reviewed?

2. Have the previous inspection reports been reviewed?

3. Were anomalies or trends detected on previous inspections?

4. Were maintenance or repairs performed since last inspection?

\begin{tabular}{|l|l|l||}
\hline YES & NO & EXPLANATION (required if shaded box is checked) \\
\hline & & \\
\hline & & \\
\hline & & \\
\hline
\end{tabular}

\section{SITE INSPECTION PREPARATION}

Assemble the following, as needed, to conduct inspections:

a. Radio, pager, etc.

b. Previous letter report, inspection checklists, repair records, and as-built plans

c. Other miscellaneous support equipment

\section{SITE INSPECTION}

1. Site markers:

a. Are both brass plates intact and readable?

b. Have any posts been damaged or their anchoring weakened?

c. Are any of the 4 use restriction signs damaged or missing?

d. Are all use restriction signs legible?

e. How many signs need to be replaced?

\begin{tabular}{|l|l|l||}
\hline YES & NO & EXPLANATION (required if shaded box is checked) \\
\hline & & \\
\hline & & \\
\hline & & \\
\hline & & \\
\hline
\end{tabular}




\section{POST-CLOSURE INSPECTION CHECKLIST}

\section{CAU 554: AREA 23 RELEASE SITE - CAS 23-02-08, USTS 23-115-1,2,3/SPILL NO. 530-90-002}

2. Photograph Documentation (optional):

a. Have photographs been taken of the site?

If yes, how many photos were taken?

If yes, has a photographic log been prepared?

\section{E. FIELD CONCLUSIONS}

1. Are more frequent inspections required?

2. Are existing maintenance/repair actions satisfactory?

3. Is other maintenance/repair necessary?

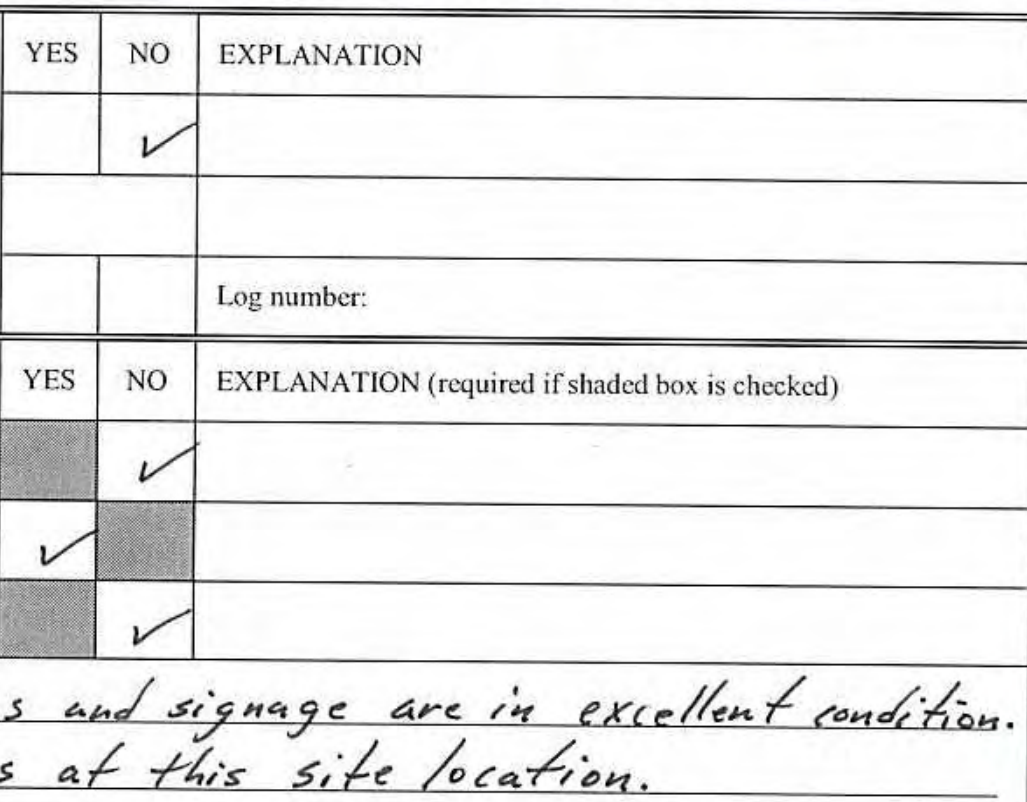

4. Field conclusionsirecommendations: The postings and signage are in excellent condition. There arenissues or concerns at this site location.

\section{F. CERTIFICATION}

I have conducted an inspection of CAS 23-02-08, USTs 23-115-1,2,3/Spill No. 530-90-002, in accordance with the procedures of the Post-Closure Plan as recorded on this checklist, attached sheets, field notes, photographs, and photograph logs.

Chief Inspector's Signature: /s/ Glenn Richardson

Printed Name: 